DEPARTMENT OF COMMERCE . BUREAU OF STANDARDS

S. W. STRATTON \& DIRECTOR

MISCELLANEOUS PUBLICATIONS-No. 41

Weights and Measures

st

Twelfth Annual Conference OF REPRESENTATIVES FROM VARIOUS STATES HELD AT THE BUREAU OF STANDARDS WASHINGTON, D. C., MAY 21, 22 23, AND 24, 1919

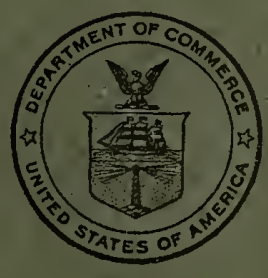

PRICE, 20 CENTS

Sold only by the Superintendent of Documents, Covernment Printing Office, Washington, D. C.

WASHINGTON

GOVERNMENT PRINTING OFFICE 


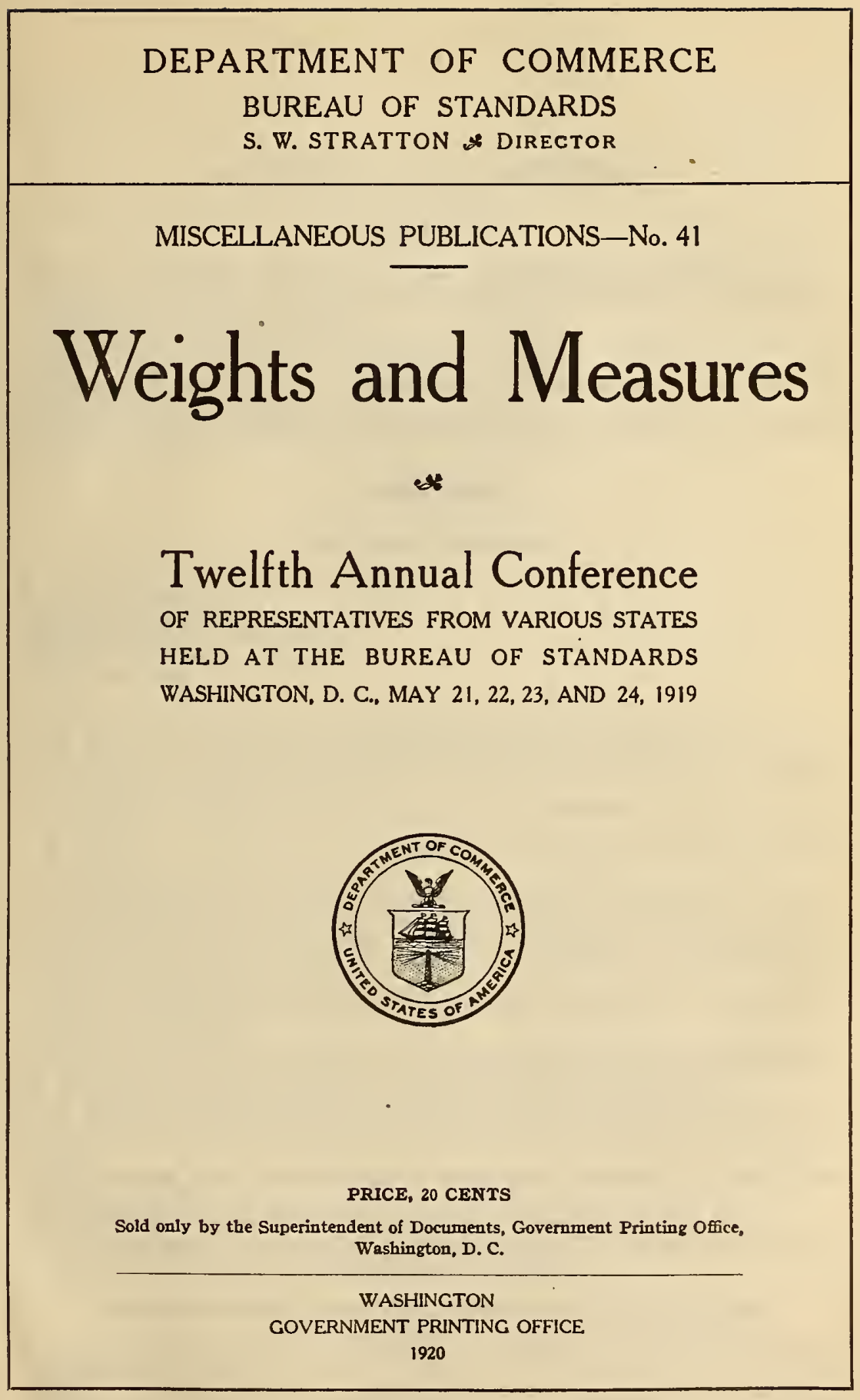




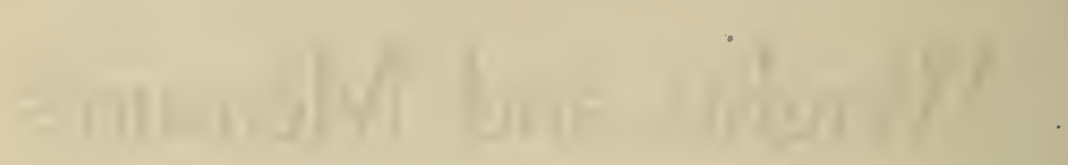




\section{OFFICERS AND COMMITTEES.}

\section{OFFICERS.}

President, S. W. Stratron, Director, Bureau of Standards, Washington, D. C.

First Vice President, CHAs. G. Joнnson, State Superintendent of Weights and Measures, Sacramento, Calif.

Second Vice President, Thure Hanson, Commissioner of Standards, The Statehouse, Boston, Mass.

Secretary, Lours A. FIscher, Chief, Division of Weights and Measures, Bureau of Standards, Washington, D. C.

Treasurer, FRANK WANSER, State Superintendent of Weights and Measures, Trenton, N. J.

\section{COMMITTEES.}

EXECUTIVE COMMITTEE.

S. W. Stratton,

CHas. G. JoHNSON,

THURE HANSON,

Lours A. Frscher,

FraNK WANSER,

F. G. BARNARD, Sealer of Weights and Measures, Battle Creek, Mich.

W. F. ClUETT, Chief Deputy Inspector of Weights and Measures, Chicago, Ill.

T. F. EgaN, Superintendent of State Police and State Superintendent of Weights and Measures, Hartford, Conn.

D. A. Gregg, Deputy State Superintendent of Weights and Measures, Austin, Tex.

J. J. Holwell, Commissioner, Mayor's Bureau of Weights and Measures, Municipal Building, New York City.

T. L. Invine, Inspector of Oil, Weights, and Measures, Salt Lake City, Utah.

T. F. MAHoNEY, Sealer of Weights and Measures, Chattanooga, Tenn.

O. Evans Miresert, County Sealer of Weights and Measures, Washington, Pa.

J. M. Mote, Assistant Chief State Inspector of Weights and Measures, Statehouse Annex, Columbus, Ohio.

Chas. C. Neare, State Commissioner of Weights and Measures, Old State Capitol, St. Paul, Minn.

ANTon RunBecK, State Inspector of Weights and Measures, Mobridge, S. Dak.

R. W. Smrth, Chief State Inspector of Weights and Measures, Madison, Wis.

W. F. Sterner, Sealer of Weights and Measures, Milwaukee, Wis.

G. B. STEWART, State Inspector of Weights and Measures, Morgantown, W. Va.

F. W. TUCKER, Chief State Inspector of Weights and Measures, Indianapolis, Ind.

H. A. WEBsTER, State Commissioner of Weights and Measures, The Statehouse, Concord, N. $\mathbf{H}$.

W. T. WhIтE, Director, Bureau of Weights and Measures, Albany, N. Y.

F. L. Woopworth, Food and Drug Commissioner, and ex officio State Superintendent of Weights and Measures, Lansing, Mich.

\section{COMMITTEE ON SPECIFICATIONS AND TOLERANCES.}

F. S. HoLвRоок, Inspector of Weights and Measures, Bureau of Standards, Washington, D. C.

Chardes G. JoHnson, State Superintendent of Weights and Measures, Sacramento, Calif.

W. F. ClukTT, Chief Deputy Inspector of Weights and Measures, Chicago, Ill. 


\section{COMMITTEE ON LEGISLATION.}

D. A. Gregg, Deputy State Superintendent of Weights and Measures, Austin, Tex.

JoSEPH J. HoLwell, Commissioner, Mayor's Bureau of Weights and Measures, New York City.

I. M. HowerL, State Superintendent of Weights and Measures, Olympia, Wash. R. W. SMrth, Chief State Inspector of Weights and Measures, Madison, Wis. EDwin F. Stimpson, Deputy State Sealer of Weights and Measures, Lawrence, Kans.

\section{ACTING COMMITTEES FOR THIS CONFERENCE.}

COMMITTEE ON PUBLICITY.

Leo S. SchoENThaL.

O. Evans Mikesell.

BeNJ. M. SHARP.

COMIMITTEE ON ENTERTAINMENT.
A. W. Sch Wartz
F. G. BARNARD.
C. A. Briggs.

IN CHARGE OF EXHIBITS.

MI. J. J. HABRISON. 


\section{LIST OF PERSONS WHO ATTENDED THE CONFERENCE.}

\section{STATE DELEGATES.}

Connecticut.................. A. Five, Deputy Superintendent of Weights and Measures, Hartford.

WALTER F. Stiles, State Inspector of Weights and Measures. Hartford.

District of Columbia......GEo. Ir. RoBERTS, Superintendent of Weights, Mieasures, and Markets, Washington.

Delaware............... Charence C. KILLEN, Chairman, State Survey Commission, Church Building, Wilmington.

Frank L. Grier, Mrilford.

Illinois.................. W. F. CLUETT, Chief Deputy Inspector of Weights and Measures of Chicago, Chicago.

Indiana.................FRANK W. TuCKER, Chief State Inspector, Statehouse, Indianapolis.

Kansas............... EnwL F. Stimpson, Deputy State Sealer of Weights and Measures, Lawrence.

Massachusetts............Thure Hansos, Cominissioner of Standards, 194 Statelouse, Boston.

P. J. Tetrault, Inspector of Standards, 194 Statehouse, Boston.

Michigan.............. Wen I. Woowworth, Food and Jurug Commissioner, ex officio Superintendent of Weights and Measures, Lansing.

Minnesota...........G. H. StapLEs, Inspector of Weights and Measures, St. Paul.

Nebraska...............e Stuhr, Deputy Commissioner of Weights and Measures, Lincoln.

New Hampshire.......... HAROLD A. WEBSTER, Commissioner of Weights and Measures, Statehouse, Concord.

New Jersey...............FANK WANSER, State Superintendent of Weights and ILeasures, Trenton.

A. W. SchwaRTz, Assistant State Superintendent of Weights and Measures, Elizabeth.

J. Frink Fowner. Assistant State Superintendent of Weights and Measures, 120 Bridge Street, Trenton.

Elirott Bolstros, Assistant State Superintendent of Weights and Measures, 128 Maple Avenue, Newark.

Charles H. Holtz, Assistant State Superintendent of Weights and Measures, 120 Bridge Street, Trenton.

New York............W. T. WhiтE, Director, Bureau of Weights and Measures, Albany.

JOHN F. FARRELL, formerly State Superintendent of Weights and Measures, 55 Liberty Street, New York City.

F. Reichmans, formerly State Superintendent of Weights and Measures, 164 Plant Avenue. Webster Groves, JIo.

Ohio................. Jors If. Mote, Assistant Chief Inspector, Statehouse Annex, Columbus.

Pennsylvania........... Jayes Swe Enex, Commissioner of Weights and Mreasures, Harrisburg.

Rhode Island.......... WM. F. Goobwix. State Sealer of Weights and Measures Room 20, Statehouse, Providence.

South Carolina..........H. W. JCCCREIGHT, Chief Clerk, Department of Agriculture, Commerce, and Industry, Columbia.

South Dakota............ Antov Runbeck. State Inspector, Mfobridge.

Tennessee................ F. Mahover, Sealer of Weights and Measures, City Hall, Chattanooga.

Texas................ A. GREGG, Deputy Superintendent of Weights and Measures, Austin.

Utah................ T. L. IRvine, Inspector of Oil, Weights, and Measures, Salt Lake City. 
Virginia

.C. H. MorrissetT, Secretary, Board of Legislative Research of Virginia, Richmond.

West Virginia.............. B. STEWART, Inspector of Weights and Measures, 194 Charles Avenue, Morgantown.

Wisconsin.............RALPH W. SMITH, Chief Inspector of Weights and Measures, Madison.

\section{CITY AND COUNTY DELEGATES.}

Connecticut:

Bridgeport......... Dennis Kelly, Sealer of Weights and Measures.

Fairfield County...... Wruliam H. Brown, County Sealer of Weights and Measures, Bridgeport.

New Britain.......... CARL A. CARLSON, Inspector of Weights and Measures, 76 Prospect Street.

Stamford............ JoHn F. BritTon, Sealer of Weights and Measures.

District of Columbia:

Washington........... Leo S. Schoenthal, Chief Inspector of Weights, Measures, and Markets, District Building.

Geo. A. Howe, Inspector of Weights, Measures, and Markets, Room 313, District Building.

W. C. Drlle R, Inspector of Weights, Measures, and Markets, Room 313, District Building.

JAMES T. Townsend, Inspector of Weights, Measures, and Markets, Room 313, District Building.

GEORGE C. WRIGHT, Inspector of Weights, Measures, and Markets, Room 313, District Building.

Illinois:

Chicago.............. Wm. F. CLUetr, Chief Deputy Inspector of Weights and

Indiana: Measures.

Indianapolis..........Ev. McGurf, City Sealer of Weights and Measures.

Terre Haute.......... J. A. Buck, Deputy State Inspector of Weights and MeasIowa: ures, 833 North Fifth Street.

Sioux City............ Mrchelstetter, Sealer of Weights and Measures, 1510 Pierce Street.

Kentucky:

Jefferson County..... WILLSON OGDEN, Inspector of Weights and Measures, Louisville.

H. P. OGDEN, Inspector of Weights and Measures, Louis-

Maine: ville.

Portland..............ugustus F. Bove, Sealer of Weights and Measures.

Massachusetts:

Beverly.............RoBert J. RAFFERTY, Sealer of Weights and Measures.

Cambridge.............. Fenix C. McBride, Sealer of Weights and Measures, Brattle Square.

Lowell..............WArren P. RIordan, City Sealer of Weights and Measures.

Newton.............Andrew Prior, Sealer of Weights and Measures, City Hall.

Salem...............GeORGE L. DAY, Sealer of Weights and Measures.

Michigan:

Battle Creek......... Fred G. Barnard, City Sealer of Weights and Measures, City Hall.

Detroit............. GeORGE F. Austin, Sealer of Weights and Measures.

Flint.................. Enw. J. Friar, Inspector of Weights and Measures, City Hall.

Montana:

Phillips County ......W. G. Schnemer, Clerk and Recorder, Malta. New Jersey:

Bayonne................ HarRy Matnhard, Superintendent of Weights and Measures.

Bergen County ...... . JoHn R. O'Connor, Superintendent of Weights and Measures, North Arlington.

Burlington County....JонN B. BurTIS, County Sealer of Weights and Measures, Columbus. 
New Jersey-Continued.

Camden.............HARry F. Redding, Superintendent of Weights and Measures.

Cape May County.....PAul E. CARroll, Superintendent of Weights and Measures, Dennisville.

Elizabeth..........WILliam J. Bender, Superintendent of Weights and Measures.

Gloucester County....WM. P. ABDELL, Superintendent of Weights and Measures, National Park.

Hudson County....... Thomas J. WALDRON, Superintendent of Weights and Measures, Courthouse, Jersey City.

Jersey City...........JoHN S. BURKE, Superintendent of Weights and Measures.

Kearny (Newark P. O.)JoHN D. CASTLEs, Superintendent of Weights and Measures.

Mercer County........STEPHEN PLANT, Superintendent of Weights and Measures, 1055 Indiana Avenue, Trenton.

Middlesex County ... NATHaN RobINs, Sealer of Weights and Measures, Metuchen.

Monmouth County....G. V. Jounson, Superintendent of Weights and Measures, Highlands.

Morris County.........HENRY S. Worman, Superintendent of Weights and Measures, Boonton.

Newark ............ .JoHN H. Suluivan, Superintendent of Weights and Measures, City Hall.

Patrick J. CaUfield, Assistant Superintendent of Weights and Measures.

Thомаs J. Brennan, Supervising Inspector of Weights and Measures, 173 Thirteenth A venue.

BERNARD J. KELLX, Assistant Superintendent of Weights and Measures, 436 South Fourteenth Street.

Passaic County...... HARRY RosenfeLt, County Superintendent of Weights and Measures, Paterson.

Trenton.............JAMES O'D ONOVAN, Municipal Superintendent of Weights and Measures.

Union County........ IsAaC SEELEY, County Superintendent of Weights and Measures, 25 Rohway Avenue, Elizabeth.

Warren.............ABRAM RAUB, County Superintendent of Weights and

New York:

\section{Measures, Harmony.}

Allegany County ..... ALLEN W. Conw IN, Sealer of Weights and Measures, Wellsville.

Erie County.......... Clarence L. Egbert, Acting County Sealer of Weights and Measures, Alden.

Greene County ........ARchIE D. Clow, Sealer of Weights and Measures, Catskill.

New York City....... Joseph J. HoLwell, Commissioner, Mayor's Bureau of Weights and Measures, Municipal Building.

Fred H. TIghe, Deputy Commissioner, Mayor's Bureau of Weights and Measures.

Steuben County......Leonard B. WaLKer, Sealer of Weights and Measures,

North Carolina: Bath. Ohio:

New Hanover County.G. C. Srmmons, Standard Keeper, Wilmington.

Champaign County....W. S. Correy, County Auditor, Urbana.

Columbiana County...R. M. Patterson, Lisbon.

Knox County.........J. C. Trnkex, Deputy County Sealer of Weights and Measures, Mount Vernon.

Medina County...... J. D. DANNLEx, Deputy Sealer of Weights and Measures,

Pennsylvania: Medina.

Allegheny County....George B. Moore, Chief Inspector of Weights and Measures, Pittsburgh.

Allentown............. Frank RINN, Inspector of Weights and Measures.

Bethlehem............. ERWIN H. SEIFERT, Inspector of Weights and Measures.

Bucks County......... L. C. ConweLL, Inspector of Weights and Measures, Holland. 
Pennsylvania-Continued.

Cameron County.......F. H. Wheaton, Inspector of Weights and Measures, Emporium.

Chester County........ CHAS. C. TownSEND, Inspector of Weights and Measures, West Chester.

Harrisburg...........George B. Nebinger, Bureau of Weights and Measures, 222 Market Street.

Lehigh County........HARrY BierY, Inspector of Weights and Measures, Allentown.

Philadelphia County. BenJ. M. SharP, Chief Clerk, Bureau of Weights and Measures, 119 Parkway Building, Philadelphia.

T. A. Seraphin, Special Inspector of Weights and Measures, 119 Parkway Building, Philadelphia.

Pittsburgh ..........Murray G. Livingston, Chief Inspector, 225 City and County Building.

William B. McGrady, Inspector of Weights and Measures, 225 City and County Building.

Washington County.... O. Evans Mikeselt, County Sealer of Weights and Measures, Washington.

Tennessee: Utah:

Chattanooga........... T. F. MAHONEY, Sealer of Weights and Measures. Virginia:

Salt Lake City.........T. L. Irvine, Inspector of Oil, Weights, and Measures.

Roanoke.............. R. VAUGHaN, Sealer of Weights and Measures.

Wisconsin:

-Milwaukee...........WM. F. Steinel, Sealer of Weights and Measures.

\section{DELEGATES FROM STATE ASSOCIATIONS OF WEIGHTS AND MEASURES.}

Massachusetts............State Association of Sealers of Weights and Measures:

GEORGE L. DAY, Sealer of Weights and Measures of Salem, Mass.

New York..............Weights and Measures Association of the State of New York:

F. ReichmanN.

\section{VISITORS REPRESENTING MANUFACTURERS.}

Anerican Automatic Scale Co.:

Henry Diemer, Service Man, 100 Weirfield Street, Brooklyn, N. Y.

American Kron Scale Co.:

F. V. Atree, District Manager, Baltimore, Md.

Ernst OHnet, Treasurer, 430 Easi Fifty-third Street, New York, N. Y. Angldile Scale Co.:

F. A. OAtes, Superintendent, Elkhart, Ind.

J. G. Srmas, President, Elkhart, Ind.

Chatillon, John, \& Sons :

J. G. HuGEL, 87 Cliff Street, New York, N. Y.

Dayton Moneyweight Scale Co.:

D. J. Morniman, Eastern Sales Manager, Boston, Mass.

Detroit Automatic Scale Co.:

W. J. Barnes, Special Representative, Detroit, Mich.

Dover Stamping Manufacturing Co.:

E. S. Rice, Cambridge, Mass.

Carlton S. Whitnex, Cambridge, Mass.

Horace E. Whitnex, President, 385 Putnain Avenue, Cambridge, Mass.

E. \& T. Fairbanks \& Co.:

L. R. Boyen, Traveling Representative, St. Johnsbury, Vt.

P. C. Brooks, General Manager, 30 Church Street, New York N. Y.

The Fairbanks Co.:

C. J. LaForge, 416 Broome Street, New York, N. Y.

General Automatic Scale Co.:

L. F. AMSDEN, Baltimore, Md.

EDwin C. Jones, Woodard Building, Washington, D. C.

W. F. Siegmund, Sales Manager, 415 Pierce Building, St. Louis, Mo.

M. D. VARNEY, 21 Park Row, New York, N. Y. 
Gilbert \& Barker: Manufacturing Co.:

A. B. Dickinson, Washington, D. C.

Elmer E. YAKE, Engineer, Springfield, Mass.

Guarantee Visible Measure Sales Co.:

W. S. Townsend, Vice President, Washington, D. C.

Henry Troemner:

Samuel B. Peterman, Philadelphia, Pa.

Liquid Measuring Device Corporation:

J. F. Milligan, 120 Broadway, New York, N. Y.

Louis F. Nafis (Inc.) :

Louis F. NAFis, President, 544 Washington Boulevard, Clicago, Ill.

Mabel S. NAFis, Secretary, 544 Washington Boulevard, Chicago, Ill.

The Measuregraph Co.:

J. A. Cochrane, District Manager, 349 Fifth Avenue, New York, N. Y.

D. C. Palmer, Northeastern Representative, 99 Chauncy Street, Boston, Mass.

Pelouze Manufacturing Co.:

Albert A. Guardia, Sales Manager, Chicago, Ill.

S. F. Bowser \& Co.:

D. A. Corey, Factory Manager, Fort Wayne, Ind.

J. F. Gibbons, Representative, 206 Fvans Building, Washington, D. C.

I. F. Johnson, Manager, Experimental Section, Fort Wayne, Ind.

D. J. Milligan, Exerutive Assistant, Fort Wayne, Ind.

Smith Scale Co.:

J. F. Sullivan, Special Representative, 611 North Forester Street, Columbus, Ohio.

Standard Computing Scale Co.:

M. D. RibBLe, Detroit, Mich.

Standard Scale and Supply Co.:

A. H. Cheslex, Special Representative, 1631 Liberty Avenue, Pittsburgh, Pa. Nathan Hause, Manager, Baltimole, Md.

Tokeim Oil Tank \& Pump Co.:

J. A. Mesker, Agent, Fort Wayne, Ind.

M. B. Matxen, Vice President, Fort Wayne, Ind.

Toledo Scale Co.:

G. A. W. Bexl, General Agent, 221 North Calvert Street, Baltimore, Md. George R. Frie, Toledo, Ohio.

C. B. Haskim, Salesman, 221 North Calvert Street, Baltimore, Mol.

H. O. HEM, Consulting Engineer, Toledo, Ohio.

.Toнn L. Theobald, Eastern Representative, 1219-21 Filbert Street, Philadelphia, Pa.

Wayne Oil Tank \& Pump Co.:

F. A. BEan, Consulting Engineer, Chicago, Ill.

Whitall Tatum Co.:

Ben.. S. Thorpe, Assistant Manager, 410 Race Street, Philadelphia, Pa.

WM. H. Nicholson, Jr., Assistant Works Manager, Millville, N. J.

Winslow Government Standard Scale Works:

Marlow H. Winslow, President, Terre Haute, Ind.

W. \& L. E. Gurley :

H. M. DiberT, Sales Manager, Troy, N. Y.

W. L. EgY, Assistant Engineer, Troy, N. Y.

\section{VISITORS REPRESENTING RAILROADS AND WEIGHING DEPART- MENTS.}

Alfrex, H. H., Scale Inspector, C., R. I. \& P. Ry. Co., El Reno, Okla.

Barry, Keller H., Foreman Scale Shop, Pa. R. R. Co., Altoona, Pa.

Basler, F. M., Scale Inspector, Pa. R. R. Co., Altoona, Pa.

Chapman, W. S., Scale Inspector, P., C., C. \& St. L., Indianapolis, Ind.

Dower, JoHn, Supervisor Weights, Merchants Exchange, St. Lou is, Mo.

Epright, A. W., Chief Scale Inspector, Pa. R. R. Co., Altoona, Pa.

Gifford, JAs. S., Foreman, Scale Department, Carnegie Steel Co., Munhall, Pa.

Gow, R. B., Superintendent of Weighing, I. C. R. R., Chicago, Ill.

GoRdon, B. B., Scale Inspector, Pennsylvania Lines West, Logansport, Ind.

KInG, C. A., Chief Scale Inspector, Western Weighing and Inspection Bureau, Chicago, Ill.

LADD, M. H., Chief Weigher, Chamber of Commerce, Milwaukee, Wis. 
Mayfield, R. R., Assistant Scale Inspector, Pennsylvania Lines West, Cincinnatti, Ohio.

MUnencH, W. J., Chief Clerk, Weighing Department, A., T. \& S. F. R. R., Chicago, Ill.

Persun, C. A., Scale Inspector, Pa. R. R. Co., Altoona, Pa.

Schmitz, J. A., Assistant Weighmaster, Board of Trade, Chicago, Ill.

Ward, William C., Scale Inspector, Pa. R. R. Co., Altoona, Pa.

Zitibel, A. G., Supervisor of Scales, T. \& P. R. R., Texarkana, Tex.

\section{VISITORS REPRESENTING GOVERNMENT DEPARTMENTS.}

Alsberg, C. F., Chief, Bureau of Chemistry, Washington, D. C.

BAKER, Thomas C. J., Inspector, Bureau of Markets, Washington, D. C.

Downing, Fred P., Investigator in Marketing, Bureau of Markets, Washington, D. C.

GaTEWood, C. B., Lieut. Col., Ordnance, U. S. Army, War Department, Washington, D. C.

Loostn, Jno. R., Weighing Supervisor, American Railway Express, Chicago, Ill. Wells, W. C., Pan American Union, Washington, D. C.

\section{GUESTS AND OTHER PERSONS ATTENDING THE CONFERENCE.}

BogGS, Mrs. L. D., Secretary, Survey Commission of Delaware, Wilmington. Cortwin, Mrs. A. W., Wellsville, N. Y.

Dannley, Mrs. J. D., Medina, Ohio.

HASLEY, F. A., American Institute of Weights and Measures, New York, N. Y. Holbrook, ERnest E., Washington, D. C.

IToNk, FrED H., Official Stenographer, Washington, D. C.

REEL, H. D., formerly Sealer of Weights and Measures of Harrisburg, Pa.

SMITH, Lestie C., Secretary, National Association of Ice Industries, Chicago, 111. Wilkinson, O. F., City Ice Delivery Co., Cleveland, Ohio. 


\section{CONTENTS.}

Fibst Session (Morning of Wednesday, May 21, 1919).

Address by the president, Dr. S. W. Stratton.

Report of the secretary, I. A. Fischer, chief of the Division of Weights and Measures, Bureau of Standards

Report of the treasurer, subınitted by L. A. Fischer, for Burr B. Lincoln_ Appointment of special resolutions committee

Reports of State delegates:

California, Charles G. Johnson

Connecticut, Charles A. Fine

Delaware, Clarence C. Killen

District of Columbia, Geo. M. Roberts

Illinois, Wm. F. Cluett

Indiana, Frank W. Tucker

Kansas, Edwin T. Stimpson

Massachusetts, Thure Hanson

Michigan , Ered

Second Session (Afternoon of Wednesday, May 21, 1919).

Reports of State delegates (continued) :

Minnesota, G. H. Staples_

Nebraska, Leo Stuhr

New Hampshire, H. A. Webster

New Jersey, Frank Wanser.

New York, W. T. White

Ohio, John M. Mote-

Pennsylvania, James Sweeney-

Rhode Island, Wm. F. Goodwin

South Carolina, H. W. McCreight

South Dakota, Anton Runbeck-_.-_-

Tennessee, T. F. Mahoney-

Texas, D. A. Gregg

Utah, T. L. Irvine

Virginia, C. H. Morrissett ..........

West Virginia, G. B. Sfewart

Wisconsin, Ralph W. Smith__-_-_Reports of delegates from other States:

Maine Augustus F. Bove

North Carolina, G. C. Simmons

Goval of tyme of appara

Address by Thure Hanson, commissioner of standards of Massachusetts

Mechanical versus supervisional weights and measures work, by Ralph W. Smith, chief inspector of weights and measures of Wisconsin

The sale of wood, by $\mathbf{H}$. A. Webster, commissioner of weights and measures of New Hampshire.

Progress of track-scale investigation, by E. D. Gordon, Bureau of Standards

Third Session (Morning of Thubsday, May 22, 1919).

Automatic scales, by H. O. Hem Appointment of committees and discussion of program Association of Ice Industries 
Inspection and regulation of taximeters, by George F. Austin, city sealer of Detroit.

Remarks by $\mathbf{F}$. Reichmann, former State superintendent of weights and measures of New York__._-

Salary system versus fee system of inspection, by George H. Staples, inspector of weights and measures of Minnesota._.

Appointment of committee on resolutions

The present movement toward obtaining standard shipping containers for marketing fresh fruits and vegetables, by F. P. Downing, Bureau of Markets

Discussion of above paper

Page.

Fourth Session (Afternoon of Thursday, May 22, 1919).

Work of the Ordnance Department, by Lieut. Col. C. B. Gatewood, Ordnance, U. S. Army

Address in memory of Mr. John C. Connors

\section{F'tfth Session (Morning of Friday, May 23, 1919).}

Recent developments in specifications for railroad track scales, by $\mathrm{C}$. $\Lambda$. Briggs, Bureau of Standards

The metric system, by F. A. Halsey, American Institute of Weights and Measures

Discussion of above paper

Address by Hon. William C. Redfield, Secretary of Commerce

Weights and measures of Latin-American countries, by W. C. Wells, Pan American Union

Discussion in regard to program

Federal regulation of weighing and measuring devices, by Joseph J. Holwell, commissioner, Major's Bureau of Weights and Measures, New York City

Discussion of above paper

Sixth Session (Afternoon of Friday, May 23, 1919).

The problem of weights in the handling of grain, by J. A. Schmitz, assistant weighmaster, Chicago Board of Trade._.

Discussion of above paper.

Discussion in re marking of wrapped hams, bacon, and other meats

Enforcement of net-weight amendment to the food and drugs act, by

C. L. Alsberg, chief, Bureau of Chemistry

Discussion of above paper
Mine scales and mine-scale investigation, by $M$. J. J. Harrison, Bureau of Standards

Discussion of above paper.

Election of officers

Report of committee on nominations.

Seventh Session (Morning of Saturday, May 24, 1919).

Liquid-measuring pumps. $A$ symposium of experiences and ideas for properly regulating this class of apparatus. Discussion opened by F. S. Holbrook, Bureau of Standards

Discussion continued by members

Tentative specifications and tolerances for liquid-measuring numps proposed by the Bureau of Standards, and the discussion thereon Report of committee on resolutions_

Resolution in re decimal-weight flour bill----.--

Resolution in re Federal serialization of type

Resolution in re sale of commodities by weight--_-
Resolution in re metric system

Resolution in re education of public

Resolution in re standardization of packages 
Report of special committee on resolutions

Eighth Session (Afternoon of Saturday, May 24, 1919).

Report of committee on resolutions (continued)

Resolution in re metric system

Resolution of appreciation to Secretary of Commerce

Resolution of appreciation to various members of the Bureau of Standards

Resolution of appreciation to other persons assisting

Creation of permanent committee on legislation

Report of committee on sales by weight

Discussion of above report

Remarks by Dr. S. W. Stratton, president

Discussion of questions involving legal procedure

Report of committee on publicity

\section{APPENDIX.}

Specifications and tolerances for liquid-measuring pumps 



\title{
REPORT OF THE TWELFTH ANNUAL CONFERENCE ON WEIGHTS AND MEASURES OF THE UNITED STATES
}

\author{
HELD AT THE BUREAU OF STANDARDS, WASHINGTON, D. C., MAY 21-24, 1919.
}

\section{FIRST SESSION (MORNING OF WEDNESDAY, MAY 21, 1919).}

The conference was called to order at 11.15 o'clock a. m. by Dr. S. W. Stratton, president of the conference and Director of the Bureau of Standards.

\section{ADDRESS BY THE PRESIDENT, DR. S. W. STRATTON.}

Gentuemen: We are glad to see you here this morning after your prolonged absence. I see among you a great many new faces, and, what is more encouraging, I know from talks I have had with you, and from your general appearance, that you come interested in the really important business of weights and measures. This organization was established some 10 or 12 years ago or more; so long ago that I have lost track of it. In the early days we had meetings of half a dozen people present from two or three States interested in these matters. It has been a hard, long, uphill job to get the weights and measures officials throughout the country interested.

I think it well at this time to repeat our object in starting this movement. When the Bureau was established, we were very much surprised to find that, while Congress had given standards to each of the States and had assisted by a little national legislation, there were many State laws, but little administration of such State legislation. The weights and measures laws of nearly every State were more or less dead letters, owing to the fact that not only in weights and measures administration in State affairs but in national affairs we often forgot that the provision for the standard is but part of the story. The rest is the provision for its use. Our standards at the Bureau, no matter how carefully they are prepared, no matter how carefully they are preserved, whether those of weights and measures or of electricity, or temperature, or what not, do not mean much if we do not develop at the same time methods for their use. This means all the apparatus involved and the different means of providing for fixing the standards for the public and the manufacturers and comparing them with our own standards. Now, we have realized at the Bureau that all this is an exceedingly important part of the problem, and we have done what we could to carry out this phase of it.

Preparing for the use of a standard is far more difficult than the preparation of the standard itself. Our efforts here included the preparation for the use of the standards as well as the standards. Now, the same is true in the States, but there is still something to be 
done, and that is the provision for the use of these standards by the general public, and this must be through you, the administrating officials of the States and cities. It was for the purpose of making the Bureau helpful in this matter which pertains to your duties that these conferences were first called. We felt that if you gathered here once a year you would see at the Bureau the latest equipment, and, what is more important to officials from states which have not been organized, you would have an opportunity of hearing and talking with representatives from the States older in the business. That has proven a remarkable success.

Moreover, just as you must have the assistance of the Bureau in carrying out this work, so the Bureau must have your assistance in providing for the fundamentals here. It is through your organization, your representation, that we know what is necessary-that we can reach the public; that we are made aware of existing conditions. Your services are just as essential to us as ours are to you, and we have recognized that from the beginning. Unfortunately, some of our earlier meetings were not devoted strictly to the technical things in mind, and that was due very largely to the fact that we had but few technical representatives present.

Now, in looking over the program for this meeting, I am delighted to see that it is a program of definite papers-papers which will bring out your experience; papers by representatives of the Bureau which will bring out their experience. A meeting conducted on such a plan can not but be very useful to both groups. The Bureau is, of course, interested in all matters pertaining to your local legislation. It endeavors to leave those matters to local authorities; but when it comes to the technical questions involved, we are always glad to help, and to that extent we are quite willing to enter into your local affairs merely in the capacity of advisor; but beyond that we do not go and are inclined to leave local legislation and local methods to the officials concerned. This is all the more reason why we should work through the officials and why you should keep in close contact with the Bureau. We have more State representatives here this morning than ever before. We have a larger number of delegates present from all sources than we have had before, probably double the number. That means that during the last two or three years you have been active. in the States; that the subject has not been lost sight of. We have not lost sight of it at the Bureau, and our regular correspondence and the visits of officials to the Bureau have gone on just the same in so far as this was found possible.

This leads me to the next part of my statement. I see I am due a little later for a talk on war work at the Bureau, and I shall devote the rest of the time you have allotted to me this morning to that subject. A good deal of this is not strictly related to your particular line of work, but I know you will all be interested in it. We have seen a decided tendency during the past two or three years to use the Bureau for the lines that I have often suggested. Our weights and measures officials can answer many, many questions and be very helpful by keeping in close touch with the Bureau. If he is asked a question in regard to building material and if he doesn't know that, he should know that certain things are handled by the Bureau of Standards, and he ought to say, "Get in touch with the Bureau of Stand- 
ards, where maybe they can help you." We want everyone of you officials to be an agent for the Bureau of Standards in all of your activities in so far as they relate to the development of your local industries. We feel that the duties of your various officers, whether State or municipal, will be very greatly enlarged and that you will handle very many more things than you handle now. As tliat work increases so your connection with the Bureau will grow in importance, and there is no reason why the Bureau should not serve one thousand people where it serves one now, and you can assist us very greatly in bringing that about.

During the war our functions were not changed. Our organization was not changed. We did not have enough people. We did lot have enough funds, but the military departments came to our assistance. The Bureau is not organized along that line of activity.

Take, for example, weights and measures. Youare familiar with the Weights and Measures Division, devoted to matters pertaining to length and capacity, weights, and time. The same staff kept at this work, augmented by the military departments, because the questions pertaining to these matters came from the military rather than the public. In the Weights and Meqsures Division the very first military activity was the standardization of precise-length gauges used in making munitions. We know from the experience of the Europeans that unless such gauges are standardized at a definite place and made uniform the munitions will not be interchangeable. Our military departments were organized on a small scale. The navy yards and some arsenals would naturally use the things that were completely interchangeable so far as their own work was con('erned; but a new condition arose. It was necessary for each of the military departments to call upon a vast number of manufacturers to make all sorts of things here and there and assemble them. The best illustration of that is the Liberty engine, but all sorts of munitions also fell in that class. It was necessary for the Bureau to anticipate this war need even in advance of the War Department. Hence an-appropriation was secured for the standardization of gauges, and at about the time this work was started the War Department then realized its importance and took from us $\mathrm{Mr}$. Fischer, chief of the Weights and Measures Division, and commissioned him a major. That in a way was rather fortunate, because his services there were very helpful to those people who had little experience in sucl matter's, but he still kept in touch with the Bureau, and this created a working relation between the Bureau and the War Department, especially the Bureau of Ordnance, which had to do most of this work. A very lar'ge staff was gotten together and provision made for comparing these master ganges with the fundamental standards of length. Thousands of such gauges were compared, and one of the interesting things that came up in connection with this work was our breaking away from importing certain classes of standards.

Mechanics and those engaged in work of this kind must use end standards; that is, standards in which the length is measured from end to end rather than between marks on the standard. 'The standards in the early days were end standards, difficult to use. Srientific men require a greater degree of precision, and therefore adopted $155530-20-2$ 
line standards because they could draw very fine lines and accurately measure the distance between the lines. It is difficult to transfer measurements from a line standard to an end standard. These end standards which were so convenient, and which you can see when you visit the gauge section of the Weights and Measures Division, are blocks the two opposite sides of which are at a definite distance from each other and they must be plane and parallel. It is very difficult to take a block of material and get the two opposite sides plane and parallel. That is why they abandoned end standards in the early days. They didn't know how to make these opposite ends both plane and parallel. Methods were later devised for doing this, and we were importing from Sweden block guages made by one company. The faces were so perfect that they would slide together with practically no error betrreen. We could not, of course, proceed to use these blocks as oursstandard of measurement so we were compelled to test them and compare them with the bar which is our standard of length. The method of comparison finally adopted brought out one of the most interesting things in the history of weights and measures.

You know that for many years physicists endeavored to provide a standard of length, a standard which could not be destroyed but which could be set up anywhere. Until recently we depended upon a particular bar of metal which was preserved somewhere and which had graduation marks upon it. Fifteen or twenty years ago, physicists determined the relation between certain wave lengths of light, which, as you know, is propagated by waves. A definite kind or color of light is always of the same wave length. The standard bar-the meter gauge at Paris-was compared with the wave length of light. Now, knowing the exact number of wave lengths in this standard bar and knowing the relation between the standard meter and the standard yard, we at once have the relation between all three and can pass from one to the other as readily as from dollars to pounds sterling or the reverse.

Now, such end gauges, as stated, were very difficult to compare with line gauges, almost impossible to do with line standards, but we know the numerical value of measurements of wave lengths of light, and we can measure these gauges in that way. The theoretical and scientific standard that scientists developed a few years ago-the wave of light-which is now proposed as the fundamental standard of wave lengths, was used to test these master block gauges. They were not measured by the standard yard or meter.

Another interesting step is that during this period, when we were testing these ganges, a gentleman came along with a method, a proposed method, for making such precision block gauges in this country. Now, the method of making may be correct, but the workman can not. work any closer than he can test. His plan of making the gauges combined with the Bureau's plan of testing by means of wave lengths of light resulted in the making of these gauges in this country. And when you visit the Bureau you will find that a large number of these sets have been made and tested. The industry was entirely in Sweden before the war. An Americall manufacturer is now turning out such gauges, which had hitlierto been confined to one individual firm in one foreign country. The war brought out many cases where we were rompelled to depend for one article upon one producer. 
In the Weights and Measures Division there was during the war a great demand for the ordinary work of testing scales and weights of precision, and so on; but these requests came from the military bureaus, the navy yards, and arsenals which were producing enormous supplies and required the precise weights tested. They were making a great many analyses and doing experimental work; so the work of the Weights and Measures Division was precisely the same as before, but there was more of it and it came from different sources. This can be illustrated in almost all parts of the Bureau. Take, for example, other divisions-electricity, which is housed in this building. In ordinary times the Electrical Division is devoted to the development of electrical researches and measurements, radiotelegraphy, and many other practical applications of electical processes. During the war the departments were buying all sorts of electrical machinery; they were using all sorts of electrical devices, and you would be surprised to know how many of these devices the Bureau was called upon to test, especially to assist in developing:

I have time to give you just one illustration, and that is known as ranging, which is almost wholly an electrical problem. During the war guns were located-the position of the enemies' batteries was located by means of sound waves-by finding the direction of the source of sound of a gun fired at a distance. Say we had three different stations here [illustrating on blackboard]. We have these different stations here, three or more, and there is a source of sound, say, in the back part of this room. That sound radiates in spherical waves. Sound, like any other radiant energy, goes out in all directions equally and travels in spherical waves. If the sound is produced in the back part of the room-say by a single source, like an explosion-that sound, traveling as the arc of a circle reaches this center first. I can put this on the board [illustrating]. The source is shown above, and if we have our various stations along the way, we have to reach this one frrst, this one [indicating] later, and this one still later on. We can measure accurately the time that elapses between its arrival at these different stations, and this gives us the element for constructing this curve. This involves the measurement of time to the one-thousandth of a second; the unit is that or smaller, and it was used on the battlefield and guns were located quite simply with that method. It meant the measuring by these recording instruments placed at this point and reading out the record of vibrations on the photographic strip drawn before a pencil, and also at other recording stations here and here [indicating]. All of these instruments left their record on a film, and the difference of time that elapses can be read from that film and may be used to compute the distance to the gun.

One very interesting film was this record near the end of the war. One of these observing stations was observing all of these photographic strips from the various sections and interpreting them, but at 11 o'clock on that day, the vibrations ceased, and it is just as clear on that strip as it can be. I think some of them will show you that strip.

I could give you a great many examples; this we class as an electrical problem, because the measurement of those impulses were made electrically. The recording devices were all operated electrically 
and the important problem of it was the electrical part of it, and we couldn't always conduct that work on precisely the same lines.

Another illustration of our work was in connection with the use of batteries, both primary and secondary. Many millions of dollars were spent for the use of batteries, and our work in connection with testing and specifying the performance of these batteries for the military departments was very great. Much that we were doing was the same thing that we had been doing for the manufacturers and the public generally. Now, such work as is continued will be for the public, although there has always been and will continue to be a certain amount of military work.

Another very interesting illustration is in connection with the Division of Heat and Thermometry. A group of men was engaged in testing thermometers measuring the heat properties of materials, heat conductivities of materials used in refrigerating, and latent heats and conductivities of all sorts of substances. A large amount of work was done by that division in developing the constants and other data needed by the refrigerating industries. In the war we needed to know a great many facts about heat engines in connection with aviation and other kinds of internal-combustion motors. It was necessary to make measurements of radiators and carburetors and of the engines themselves, involving these same heat principles. The people who had been trained to make those heat measurements, for instance, took the Liberty engine, placed it in a room and exhausted the air, and ran that engine under the conditions they would find at an altitude of 30,000 to 10,000 feet. The temperature was lowered so we had in this chamber the precise conditions we would find above. That was a very difficult piece of investigational work where the men engaged were these experts of the Division of Heat and Thermometry. They were simply doing a different problem in that same field of physics, the problem having a bearing upon aviation.

Our Division of Optics is usually devoted to spectroscopy and polariscopic investigations and the development of instruments of various kinds and testing the instruments bought by the Government. During the war they were called upon to develop all sorts of optical instruments, gun sights, and periscopes for submarines, which it had not done before, as this division is not a military department. We were called upon to develop optical methods for all sorts of work. We were called upon to develop optical glass. In fact, the Bureau, in its material sections, had been for several years and since its existence endeavoring to assist in the building up of industry in this country, industries which did not exist before. There is no reason why we should import all of our filter paper, or our chemical porcelain, and our dyes and optical glass. We were importing glass from Germany and graphite from India.

The Bureau for some time and for another reason had been helping establish some of these industries in this country. The Burean developed porcelain and optical glass. We had been experimenting in optical glass even before the war broke out in Europe. There is no other activity which has been so hedged about with secrecy and in the hands of few people, and we were entirely dependent upon two or three foreign makers for the glass used. We were quietly trying to get at these mysteries. We must be students before we attempt to 
teach. We began in a small way and worked out sone of the principles and went through with it and put up a full-sized pot which produres a thousand pounds at a melt. It cost some thousand dollars. The pots we used in the beginning were those used for window glass. But fo secure the requisite quality of glass it was necessary to develop the pots themselves. At about the time we entered the war we had a satisfactory pot developed and were familiar with the main ('ssentials of the glass work and were in a position to cooperate with manufacturers, and dirl, when they asked, and helped the manufacturers who came in to make optical glass during the war. In $8 \mathrm{or}^{\circ}$ 10 pots we made from 1 to 2 tons per month ourselves. We learned a great deal from that experimental work.

I conld talk to you for the rest of the morning in illustrations of that kind regarding the optical materials and instruments alone. The time is too short. I will give you just one more example of optical work which illustrates the fact that one never knows what scientific principle is going to be useful. I do not know of a single branch of physics, I mean of what we call the purest kind of science, that has not been used during the war and will not be used now in time of peace. Take, for example, spectroscopy. I gave you one good illustration of that in the testing of these gauges. We have been working on the interference of light waves in optics and we little thought that that would have any practical importance. We knew that in time it would be used to measure length, but it was nou suspected that it would have to be used right now. This other illustration was with spectroscopy. Our spectroscopists were experimenting with photographic plates. They used photographic plates in recording the spectra of the distant stars, and in studying the characteristics of these stars they needed plates requiring the low end of the spectrum. We call the red end the low end, and these plates are insensitive to the red lines. (That is the continuation of one of the war problems which we will speak of later.) They had dereloped a plate-that is, a photographic plate-stained with a certain dye that bccomes sensitive to the red, and so the spectroscopists conld record the longer waves in the red, which they could not record on the photographic plate before. Unfortunately, it is a particular dye made in Germany, and our supply was cut off. We lid get throughout the war sniall quantities for our use, but the thing that is of importance is that we have succeeded in making it in this comntry, and that that dye will be made here from this time on. Now, the application is this: Those red rays, the red rays of light, penctrate fogs or mist a great deal better than other rays of light. and some one suggested that these plates be nsed in aviation photography, and they turned out to give most excellent results, because ther would give photographs of objects in the distance that you could barely see with the eye, that are almost obscured by mists and haze give most beautiful photographs where the ordinary method would practically give no photograph at all; so. our astronomical experts were sent abroad to introduce this method. Here, again, this in time will be applied to all kinds of commercial photography. There are many cases in conmercial photography, and I suspect that even in the kodak the film will be stained this way so it will give better color values in the photograph. At the present 
time with the ordinary plates we get much higher value of lights and blues than we should, relatively. With these two things we had $\varepsilon$ most valuable experience in warfare, and they are going to have a greater value in time of peace.

Our Chemical Division was called upon not only to work out a great many things in comnection with these problems, but in connection with other lines of research. They had to work out pure materials and test materials and so on, for use in our own problems. There is scarcely a problem that comes up which does not in some way involve the chemical department. You have seen that in the development of helium gas for balloon work. WVe are not so sure but that the suggestion arose from this Bureau.

At the time the war broke out we had no balloon fabric in this country. Now, the people interested and our experts and manufacturers got together and the Bureau's particular function was to examine these fabrics for their property of holding the gas-their impermeability to gas. A good fabric will not let the hydrogen go through, but hydrogen is difficult to keep in.

Then there were many problems like the development of "dope" for airplane fabric. Such fabric is coated with a varnish, called a "dope," and that consisted mostly of foreign materials. New ones had to be developed. New varnish to suit certain materials had to be dereloped, and so not only was our chemical department called upon to take part in the enormous number of these developments of materials and military inventions, but the use of chemistry was so great in the war that they established a chemical warfare service, and men from that service were detailed to the Bureau. At one time ne had something like 1,200 employees and 200 soldiers and 10 cr 15 officers detailed here for our assistance. Our work from the military standpoint has not decreased, but has increased. Our militare departments will admit themselves that they did not realize the importance of the application of science. The war taught them a lesson, and they are coming to us now for many of those things they ought to have sought before and are continuing the work that was started during the war.

I have given you an illustration of a material developed in the case of optical glass. There are many others. A very notable one was the case of the fabric for airplanes. As you probably know, the airplanes were covered almost entirely with linen, and at the outhreak of the war, when this country entered into the war, Great Britain was supplying almost all the linen for her planes and for those of France and Italy. When our own planes were dereloped, it was soon seen that there would not be enough linen for the foreign planes alone, and there was a deep-seated prejudice against any other fabric. The Germans were forced to use other fabrics and developed ramie, a species of jute, more like linen cloth.

This Bureau needed this knowledge, and it came about in a curious way. I am going to tell you the story, because it will show you how these things join up together. About eight or ten years ago we were called upon to investigate the automobile-tire fabric, a strong canvas that was woven so that its strength is the same in each direction. We were called upon to settle a dispute between the maker and purchasers of a large amount of this canvas. We made a scries of tests and became familiar with the cloth. 
It occurred to us when this aviation problem came up that what was needed was the same sort of cloth, but lighter in weight. We took it up with a mill and on our own initiative had a new cloth made, knowing it would be right. When our progran was nearing the point where they had to consider what source the cloth was to come from, we received a request one day to come immediately to the War Department, and they said: "What are we going to do for linen?" Answer: "Use cotton." "Where can we get it and try it out?" At that time we had at Pensacola and Hampton Roads cloth to be tried out. It was tried in a very few days, and the office of the C'hief Signal Officer immediately placed an order for half a million yards of cotton cloth. That is made from the long staple cotton woven in a texture that takes the "dope" and has the same strength in each direction.

It is unfortunate that we couldn't have got at these things before, because when we came to buy them in great quantities we had to take what we could get and could not spring surprises upon manufacturers; but, nevertheless, they were disposed in the bureaus of the War Department to purchase these things on a definite specification as far as they could; and what is exceedingly valuable is that we have gathered a lot of experience out of this work, and that experience will be utilized by the public. The time is not far distant when we will have in this country a pure-materials law, like the pure-food law, when it is going to be a misdemeanor to misbrand a textile or any article of that kind, and that is the time when you people will be called upon to take up that class of work. If you don't, somebody else will, because it is going to be handled. It is next in importance to the pure-food law.

The same story might be told in connection with leather, rubber, lubricating oils, paper, and many of these materials. We thought that the paper section would not be called upon for military work. Paper is a substance not ordinarily used. The very first question that came to us for the papel section was building boards. The cantomments used enormous quantities of building boards, and they are classed as paper; a great many of them are paper. The next development of paper was paper to be used as a filter in the gas masks. and there are several other cases. The paper section was kept busy all the time on the development of these things.

Now, after the war, the War Department found itself in possession of, I think, six or eight million dollar's' worth of cotton linters. Linter's is the name given to cotton that is taken off the seed, the very sinall, short fiber combed from the seed, the last thing taken off. This is used as a source of cellulose in the making of smokeless powder; enormous quantities were gotten together for the making of such powder. Then with the armistice the use of powder was cut off all at once; there was no need for these linters. The great problem was what to do with this enormous quantity of cotton linters in the hands of the Government. We were called upon to make a suggestion. We found that it could be used in the making of a special silk substitute and could be used to make paper. Yet the paper people and many experts had said it was too short a fiber and that paper could not be made out of it. But in less than two weeks after they asked us the question they were given 
good paper marle in the Bureau's experimental paper mill. So, the cotton linters will make paper, and it will make good paper.

I could give you a great many illustrations like that in going from a peace basis to a war basis and the reverse, from a war basis to a peace basis, without making any change in our organization $\mathrm{or}^{\circ}$ in the class of problems. They remain the same.

I am afraid I have taken too much of your time already. A good many of these things can be seen at the Bureau, and I hope the officer's of the Weights and Measures Division will give you an op: portunity to see some of them. I think I can say that the Burean has received a vel'y great impulse due to the war work. The public understands it and its aims better than ever before. This not only applies to youl own work but to the work of all sections of the Bureau, and the great problem before us in the years to come, and especially the next five or six years, is how to help industry. We are cntering into a period that has given us a great deal of concern in this country. We are short of labor. Labor has increased in price to such an cnormons extent that it is going to be necessary to utilize machincry where we didn't utilize it before.

Furtliermole, there is going to be an enormous competition for foreign trade. We have to keep up a foreign trade because there are some things we must import, and as long as we import we must export, but, in addition to that, there is no reason why this country should not have its proportion of foreign trade. It serves to stabilize our production in many, many ways. We can only get some of this trade just as far as we excel in our manufactures.

The Bureau has established a very close relation to all of the important branches of manufacture. I will not be able to be with you to-morrow or the next day on account of having to meet with an association of the lieads of big business in New York to-morrow. It is called the Industrial Cooperation Association, where the heads of large manufacturing industries in this country are getting together with a view to considering the common interests, and one of these interests is the introduction of scientific research into their work-low they can do it and how they can cooperate with the Bureau.

One of the very large divisions of the Bureau is its metallurgical branch. I did not intend to touch upon that, but that division has been called upon to develop all sorts of light alloys for aviation work and steel alloys for almament and gurs. An enormous amount of work is being done there, and it has developed the fact that we really knew very little about steel and about some of these new lighter alloys. The iron and steel men of the country have become very greatly interested in the metalluigical work of the Bureau. So on the day following the meeting of the Industrial Cooperation Association, the Iron and Steel Institute is having a meeting in New York, and one of the things they are going to discuss is how they can assist the Bureau and how the Bureau can assist them. When the Iron and Steel Institute, composed of the financial members of the iron and steel industry, begin to ask questions of the scientific men, then I think there is some hope that we can get what we want in the future and make the Bureau still more useful to the industries.

Your work is just as much related to industries as to anything 
else. One of the vital and fundamental questions that comes up in the industries is accurate measurement of all kinds, and you will find rourselves more closely related to the industries as time goes on, and you can also help us in making the Bureau useful to the industries. There is no reason why your work should be altogether regulatory. Your primary function is regulatory, but it can be helpful at the same time. I predict in the future that you will be handling all sorts of questions in regard to the standardization of measurements.

I thank rou rery much for your attention this morning. Everything will be done liere at the Bureau to make your stay successful, and I want you to visit the various laboratories of the Bureau and get ont of them what you can. That is the story I have to tell you this morning.

REPORT OF THE SECRETARY, L. A. FISCEER, CHIEF OF DIVISION OF WEIGHTS AND MEASURES, BUREAU OF STANDARDS.

Mr. Chairman and gentlemen: One of the adrantages of being secretary of an organization which has no constitution or by-lats is that one is not compelled to confine his report within certain restricted limits, but is pririleged to discuss anything that suits his fancy. Whether the view is justified or not, it is the one I have taken in past years, and, never having been called to account, I am going to assume that I am at liberty to do the same thing once more. I can promise, however, that my remarks will be very brief. A word at this point as to the reasons why no conference has been called since 1916. Shortly after the United States rent to war with Germany, you will recall that our railroad systems showed early evidences of being badly orerstrained. Under these circumstances it did not seem desirable to impose any burden upon them not directly concerned witl the conduct of the war.

Also, as a result of the tremendous increase in the activity of the Covernment, particularly in the Army and Navy, the facilities of Washington were sererely taxed for accommodation, and it rould have been rell-nigh impossible to have secured hotel accommorlations for our nembers. Lastly, it appeared desirable to postpone all actions not directly connected with the prosecution of the rar.

These rere the main reasons which led the executive committee to deride to postpone further meetings until the fighting had ceased. In following this course the conference was in accord with the actions of other organizations for practically all of the large national organizations called off their meetings duing the same period.

Although circumstances denied us the opportunity to meet herc, there is no evidence that there was lack of interest in the rork. On the contrary, legislation. which is an index to interest, has been enacted in a number of States which have heretofore manifested rery little interest in this subject. As representatives of these States are or will be present and will be called upon to say something, I shall leare it to them to give the details.

In so far as the rork of the Bureau is concerner, there was no interruption exrept that due to the general sraprity of men of techuiral training within the inilitary age. 'The Burean was, however, able 
to hold most of its trained force, and in the same fields of work to add greatly to it by the detail of soldiers from the Army, particularly for work laving a direct military bcaring. In one section of the Weights and Measures Division-namely, the gauge section-the force rose from one or two men to over 200 in about one year. This ratio was not maintained for the whole Bureau, but the increase of the entire force was about 300 per cent. In those branches in which you are most interested our force remained about the sane as it was before the war, and the work was carried on with little serious interruption. As a mere matter of record, I might add that I was in the Army from September, 1917, until February, 1919, during which period the work was carried on very efficiently by $\mathrm{Mr}$. Holbrook and Mr. Briggs, who are on the program and will give you a full account of some phases of their work.

Since our last meeting a considerable number of our best known officials have gone into other activities and have been lost to weights and measures. Among these are Mr. William L. Waldron, commissioner of weights and measures of New Jersey and vice president of this olganization, and Mr. Burr B. Lincoln, of Michigan, treasurer. Both of them were energetic and enthusiastic, and their loss to the conference is a distinct one. Particularly shall we miss the tact and good judgment of Mr. Waldron, who could always be counted on to pour oil upon the troubled waters if they became turbulent.

Four members of the executive committee will be missed from this and future meetings. They are Mr. John F. Farrell, former State superintendent of weights and measures of New York; Mr. George E. Carpenter, former State commissioner of weights and measures of Vermont; Mr. Edward C. Lytton, chief State inspector of weights and measures of Iowa; and Mr. O. N. Creswell, State inspector of weights and measures of Arizona.

Our greatest losses, however, have been by death. First and foremost is that of Mr. John C. Connors, a menber of the committee on tolerances and specifications, whose derotion to the cause of honest weights and measures will long be remembered. There is hardly at man in our field of work who is not indebted to him for some act of lindness or for assistance in some form. Your secretary freely acknowledges his indebtedness to him for information and advice from his find of practical knowledge, which was always at the disposal of his friends.

Another death was that of Mr. John T. Willett, chief inspector of weights and measures of Indiana and a formel treasurel of the ('onference. He possessed many of the characteristics of Mr. John C. Connors, whose friend he was for many years. Still another was that of Mr. James R. Smith, a nember of our executive committec and an energetic official. Doubtless, the committer on resolutions will give us an opportunity to express in a formal way our sentiments respecting these three men.

A very full program has been arranged, and we shall have to work fast to get through with it. I shall not, therefore, take up any more of your time at this moment, but make no promises abont what. I may do later on. 
REPORT OF THE TREASURER, SUBMITTED BY L. A. FISCHER FOR BURR B. LINCOIN.

The report of the treasurer, which Mr. Lincoln has asked me to submit to the conference, is as follows:

Receipts :

By subscription ${ }^{1}$

$\$ 135.00$

Balance turned over to Mr. Willett___- 24.35

Disbursements :

Cost of canceling excursion to Chesapeake Beach_______ 60.00

Printing of tickets $\quad 9.00$

Badges 28.00

Balance on hand

$\$ 62.35$

The secretary holds the check of Mr. Lincoln for the balance of $\$ 62.35$ and will be glad to turn it orer to his successor.

\section{APPOINTMENT OF SPECIAL RESOLUTIONS COMIMITTEE.}

Mr. F. G. Barnard. Mr. Chairman, due to the fact that quite a number of the delegates hare been acquainted in the past with our deceased brother's-Messrs. John C. Connors, John T. WVillett, and James R. Smith-I desire to more at this time that a special committee be appointed by the chairman to prepare a resolution of memorial and respect upon these brothers.

(The motion was seconded and agreed to.)

The Charrurax. I will appoint as a special resolutions committee Messrs. Barnard, Holbrook, and Cluett.

Next on the program are the reports from the State delegates. Personally, I think this is one of the most interesting parts of our program, as there are always a number of new delegates, especially when we hare not had a meeting for some little time.

\section{REPORTS OF STATE DELEGATES. ${ }^{2}$}

\section{CALTFORNIA. ${ }^{3}$}

By. Charles G. Johxsox, Stute superintendent of Wrights and Measures.

The operation of the weights and measures laws in the State of California has permanently established their usefulness and practicability, and the cost of their enforcement is fully justified by the result.

The officials in the service have all seriously applied themselves to the study of the several laws and the conditions effected by their enforcement. Few changes have taken place among them, thereby retaining in the service that competency and efficiency which can best be obtained throngh practical field experience. I have always maintained that the usefulness of the laws to the public is conditioned, in a large degree, upon the personal qualification of the sealer, and in California I want erery sealer to be inspired by the confidence that

\footnotetext{
1 'This subscription was collected to cover expense incurred duc to cancellatinn of excul sinn to Chesapeake Beach.

a For convenience of referener these reports have heeu arranged in alphahetical order.

submitted by mail.
} 
their superintendent is a coworker and adviser in a service that is worthy of our earnest labors.

The wcights and measures law has been found practical and rorkable, and I conscientionsly contend that every weighing and measuring device and every weight employed in the avennes of trade should be inspected and sealed is provided. All millk bottles and other standardized containers are correct within the prescribed tolerances and all apparatus in commercial use conforms to specifications promulgated by the Bureau of Standards.

The most substantial cooperation has been developed, which minimized the necessity for prosecutions, and the general conduct of the officials is such as commands respect.

The net-container act is modeled to conform with the regulations and requirements of the Bureau of Chemistry, thereby effecting uniformity and cooperation with interstate trade. Space does not permit of recording the diversified application of this law. During 1918, $1,154,987$ container's were inspected. Nearly all bad trade customs express themselves in the sale of commodities in containers. When these have come to our attention we have prosecuted them vigorously and exterminated them. Several hundred prosecutions have been institutcd, and I hare no record of failure to obtain judgment.

One cannery of string beans declared contents at 6 pounds, and upon inspection the drained edible reighed 2 pounds and 10 ounces, and the water, 3 pounds 6 ounces. Serenteen thousand cases were placed under condemnation and relabeled, and the packers fined. Interstate shippers of 11 carloads of flour declared contents in conflict with standard net weights and were extended convenient time to refill and cause their containers to declare a truthful statement of contents.

Wood when sold is uniformly estimated and sold by the standard cord. well stowed. Grain, beans, and hay are all sold by net weight and net weight in California means just what the word implies-the weight of the container is not included in the weight of the commodity. Every safegnard is extended to commercial honesty and fair flealing. and we have no patience with short weighers or commercial misconduct.

The operation of the public-weighmaster act is solving a big problem and in a practical way accomplishing more commercial reform than any other agency. Fourteen hundred persons, firms, and corpolations have qualified as public weighmasters and are all issuing the legal form of weight certificates which are recognized in cxchange and accepted as a trine record forming the basis of settlement. By the operation of this lam the State presnumes to represent the absent party at the time the commodity is weighed. The policy of enforcement has been found practical and applicable and has dereloped commercial harmony where before there was suspicion and bad faith. All apparatus employed by public weighmasters is given special attention. All new installations are of modern construction and installed on substantial foundations, in properly prepared pits.

Many standard weights of common commodities in containers have heen established. The repartment by the standards presumes to define the meaning of such terms as "sack of coal," "sack of potatoes." "square of butter." etc. Designing persons advertised potatoes at at $\$ 2.10$ per sack, when honest merchants conld not sell for less than 
$\$ 3.50$. We found that the sacks shipped under the advertisement weighed 65 pounds. Under the standard a sack of potatoes must contain a minimum quantity of 100 pounds, net weight, and a sack of coal 100 pounds, net weight.

The dry standards of measurement have been discarded as an antiquated system based on expediency. Dry commodities are all estimated by weight, and liquid by measure.

A systematic campaign of education is constantly maintained. The State department of education is cooperating by devoting appropriate space in the textbooks to the subject of weights and measures in general, and the school children are taught the fundamental principles expressed in the weights and measures laws. All opportunities to address conventions, fraternities, organizations, and schools are accepted, and respectful attention is given the addresses.

The service is of such a character that it dignifies any person associated with it. Its underlying principles are fundamentals which humanity must accept. The protection of our standards of weight and measure is just as important as the protection of our standards of currency.

I want to take this occasion to express my sincere thanks for the valuable assistance extended to the department by the Bureau of Standards. I sincerely trust that these happy relations will continue and that I may always have the privilege of the valuable counsel of the Bureau.

\section{CONNECTICUT.}

By Chartws A. Find, lopuly stale Superintendent of Weights and Meusures.

Mr. Chairman, ladies, and gentlemen, I have a very brief report here to make. Our superintendent was not able to be here at this conference. You are pretty well acquainted with him, and as he has always taken a large interest in the weights and measures work, National and State, he was very sorry that he could not be here for this conference.

I will say for him that the weights and measures work in the State of Connecticut has steadily progressed since the last conference. Six of our eight counties now have sealers who are fairly well ('ompensated and who give close attention to their work. Our seven leading cities all have active and well-equipped sealers, several of whom are men of long experience in this work. Their last anmual reports show activity and progress.

Our law is modern in every particular, except that relating to the weights per bushel of certain commodities. In 1917 changes were made in our law giving the State department nore direct authority to seal commercial weights and measures, and it is onr policy to inspect and seal or condemn any instrument whenever we have complaint that local sealers have neglected to attend to such instrument. Our State department also gives close attention to dealer's who give short weight or measure, with particular reference to retailers of food and fuel. The results obtained meet with public approval and warrant the expense involved. These results tend to ronfirm the opinion sometimes expressed here that inspection work ran be more successfully conducted by trained inspectors who have 
no local affiliations than by sealers who are bound to be well known to offenders.

Mr. Chairman, our little State, which is not called a Commonwealth, is well represented at this conference. I find there are six men here from the small State of Connecticut. There are three city sealers-from Bridgeport, New Britain, and Stamford-and also a county sealer from Stafford County. I can not account for the fact that there are not more county sealers. Mr. Stiles, who is my associate in the work of inspecting weights and measures for the State, is also present.

In conclusion, I will say that our department has done very good work, especially during the war. Our work with several other departments was greatly appreciated in supervising sales of fuel, sugar, and a few other things. Our superintendent, who has a large experience in these lines, was able to secure an automobile which cost a handsome sum of money, and in the automobile is what we call a camouflage gasoline tank used for testing purposes. We shall be able to catch manipulators who are selling 4 gallons for 5 , with whom we have had experience in previous years.

The word "manipulation" is perfectly familiar to a good many sealers. We find many pumps the trouble with which is not the fault of the pump maker. Such pumps can be easily manipulated by men who understand their operation. In one particular case a man gare us short of 5 gallons of gasoline, and we prosecuted the gentleman and claimed that he made five strokes to 5 gallons. He claimed that he gare four strokes to 5 gallons, and simply made a mistake. But in the measure we found that there were 4 gallons and a fraction of a gallon, and so were positive that he gave five strokes instead of four. A man who is a sealer of weights and measures is familiar with the mechanism of pumps, and should learn how these pumps can be manipulated. The reason I mention gasoline is because the gasoline proposition is now one of the most vital importance. At one time in a past conference we heard a lot of talk about coal and about butter. Now, the high price of gasoline and the great amount that is being consumed make it a very important feature for the sealer to look out for. I do not think I have anpthing more to say. I should like to hear from the other sealers.

DELATARE.

By Clarence C. Kitlex, Chairman of State Survey Commission.

Mr. Chairman and delegates, it is my privilege to represent the governor of Delaware. Strictly speaking, we have no inspection of weights and measures in Delaware. One of the counties has a county inspector appointed by the governor, a very poorly paid official and one who, I am afraid, is doing poor work. In the city of Wilmington the clerk of street markets has the power of regulating weights and measures in the markets only. I am connected with the State commission, which is going to prepare legislation of this character, and we hope by the time the 1921 session meets Delaware will be in the front rank of legislation of this kind.

The Charriar. That is another rery good illustration of how this conference helps all those who are starting out. I have not the 
slightest doubt but that next year we will hear from Delaware in some active work. We have seen this so often before.

\section{DISTRICT OF COLUMBIA.}

By Gвo. M. Roвknтs, Superintendent of Weights, Measures, and Markets.

Mr. Chairman, I shall not consume all of the five minutes allotted to me. Since the last conference the force of inspectors employed in the weights and measures department of the District of Columbia has been increased by congressional action, and the scope of our work has been broadened. During that time we have taken up the work of regularly testing the gasoline-measuring pumps and prescription scales. Although this work is very important, it had never been done before, on account of the inadequacy of the inspection force. Besides doing this additional work we are now able to keep a closer watch over retail establishments and do our work more thoroughly than before.

We have not secured any other legislation. A bill to revise the weights and measures laws of the District passed the House of Representatives during the last session of Congress, but, on account of the press of war legislation, it failed to pass the Senate. I hope that a similar bill may become a law during the present session of Congress, as a new weights and measures law, for the District of Columbia is very much needed.

ILLINOIS.

By Wilisam 1 . CLUET, Chief Deputy Inspector of Weights and Measures of Chicago.

Mr. Chairman, delegates, and guests, it has beên my privilege to attend a number of these conferences. This is the first conference that $I$ have ever attended, however, in which the State of Illinois could really say they have ever made any progress in State weights and measures legislation. At the past session of our State legislature, in 1917, Senator Cliff, of Sycamore, introduced a bill regulating the weights and measures of the State and putting them under the supervision of a superintendent of standards. This bill was patterned after the model law indorsed by these conferences, and it passed through the senate of the State in fine shape, but when it reached the committee in the house it was so emasculated that very little was left that was not already in the statute. However, they did leave the office of State superintendent of standards in it, with the provision that he should inspect the measures in the State institutions, the gasoline pumps, and have the usual supervision of weights and measures in the State. Mr. Adams, of Ogle County, has been appointed superintendent of standards in the department of trade and commerce, and he works under the supervision of $\mathrm{Mr}$. Baldwin, director, and James F. Paulding, assistant director. They have procured a complete set of standards, balances, and weights, and measures and have done some little work along the lines that have been set forth.

Mr. James F. Baldwin, the assistant director, under the immediate supervision of the superintendent, has taken a keen interest 
in weights and measures work from the beginning, and early this year, when the present session of the legislature was convened, he caused to be introduced an entirely new bill on weights and measures which is patterned after and follows closely the provisions of the model law. About two weeks ago I had the pleasure of going to Springfield to appear before a committee there, and this bill has been passed through the senate in its entirety as introduced. The bill has to come up before the committee in the house and we hope that, on account of the administration of the measure being in the department of trade and commerce, it may not be emasculated, but will go through the way introduced. So we will have some regulations in Illinois that we have not had before; some things to enforce and somebody to look after the enforcement of them. The only thing done in the State in the past in the way of weights and measures legislation has been done by some city inspectors of weights and measures working under city ordinances passed in city councils under the police powers of the council. They had very little State weights and measures legislation to back them up. I hope that at the next conference I shall be able to say that Illinois is doing as good work as other States that have been in the game longer.

The Chammax. Mr. Cluett has suggested a point that often comes up here; that is, whether the Bureau should send a representative when you have matters pending before your legislatures. Our feeling in regard to that is that we do not wish to send representatives instructed to oppose or favor any specific legislation, but if at any time a representative of the Bureau is requested by a proper official to be there to discuss general weights and measures problems or to answer questions that arise, we will always send a representative. I wish to make it perfectly clear that we are not there to interfere with local conditions, but merely to be helpful and to answer questions.

\section{INDIANA.}

By Frank W. Tucker, Chief Stale Inspector of Weights and Measures.

Mr. President and gentlemen, I am representing a State that we think is second to none. We from Indiana have been very busy in the last two years in cooperating with the Government in the publichealth work and the conservation of food. At the same time, since that has passed, I have not found that we have gone backward in our department. I wish to differ with some of the representatives here in regard to the combination of the food and drug and the weights and measures departments. They may be placed in a rather peculiar position, but we have a man in Indiana that is big enough to handle both departments, namely, Dr. H. B. Barnard. I think some of you know him.

In the weights and measures department we have lost one of our representatives, Mr. Willett, mentioned earlier in the convention. The inner tube on the wheel has been blown out. I have succeeded $\mathrm{Mr}_{\mathrm{r}}$. Willett, and I hope to fill his place as well if not better than it has been filled, for the reason that I have gained in the last year some very competent county officials that have been appointed in the State. We have some 22 deputy State weights and measures in- 
spectors to-day. We have a law that counties of 50,000 inhabitants or over must have a county sealer. All other counties may have such an official. That leaves, on this basis, about 80 per cent of our population without any protection. We have tried to make it mandatory to appoint county sealers in counties having a population of 20,000 , but some of our representatives could not see why it was necessary. We got one bill through the last legislature in favor of weights and measures, and that was in regard to bread. The law in the State of Indiana now requires $\frac{1}{2}, \frac{3}{4}, 1,1 \frac{1}{2}, 3$, or 5 pound loaves, and there must be a sticker on each loaf specifying the net weight of that loaf, together with the name of the manufacturer. We claim this has already been a big protection to our bakeries against those of other States who have been shipping into our State bread under our weights. In fact, we have weighed up quite a number of "pound" loaves coming from Ohio, and also Illinois, containing only 14 ounces. We are ready at any time, and will only be too glad in the near future, to furnish to you a list of the people in your State who are violating our laws, and we would be very glad if you would furnish us with a list of people in our State who are shipping into your State in violation of your laws. We would be very glad to cooperate with you and assist you in running them down, because we do not want that class of people in the State of Indiana.

I have conferred with our jobbers' and our fruit dealers' organizations in the State of Indiana, and we are practically getting away from the bushel denomination in selling vegetables by weight. They are now beginning to sell these to the dealers on the 100 -pound basis. I would like to see a national law, as well as a State law, that would require the sale of all the dry commodities, excepting small berries, on the 100-pound basis. That would simplify the purchase to such an extent that a 14-year-old child would have no trouble in getting what he wanted. We would Jike to see the same law in adjoining States.

\section{KANSAS.}

By Edwin F. Stimpson, Deputy State Sealer of Weights and Measures.

Mr. Chairman and gentlemen, I have no written report. My coming here was rather sudden. The State of Kansas is not doing very much nor advancing very rapidly in matters of weights and measures. I think we have not been represented here for four or five years, and during that time we have allowed a law to remain on our statute books allowing gross weights on several commodities. However, in flours and things of that sort we have been able to get rid of that, so that we require net weight in the case of these commodities. We have not been able to get rid of our law allowing liquid quarts for berry boxes, however. Kansas is also still under the old system of inspection, and county clerks are still ex officio sealers; that we have been unable to change. This is one of the States where most of the inspection is done by the food and drug inspectors. They have done a great deal of work and have made prosecutions where that was necessary. Also, there is an inspector now who takes care of foodstuffs, such as sacks of feed for stock food, of which many thousands of tons are shipped into the State. They

155530-20-3 
are doing a great deal of work along that line and in reweighing are finding a great many short-weight packages among those coming into the State, as well as those put up in the State itself.

We have tried several times to get a better law and a better system of inspection for the State, but up to the present time the legislature has turned a deaf ear to any such proposition. I believe that is all I have to say.

\section{MASSACHUSETTS.}

\section{By Thure Hanson, Commissioner of Standards.}

Mr. Chairman and delegates, like Mr. Cluett and other old-timers, I am a veteran myself. Massachusetts, as you know, is not really a State; it is a great Commonwealth. I am glad to say that I represent the great Commonwealth of Massachusetts.

Relative to weights and measures, we in Massachusetts have been at that a long time. In fact, a great many of our laws date back to colonial times, but I might add that they have been amended several times since then. We feel in Massachusetts that the weights-andmeasures work, particularly in the State department, should show progress. I am absolutely in accord with Dr. Stratton's ideas on the law of progress. I do not want to stand still; I would rather quit the job. My idea is to go ever forward; just the same as when going to school. If you stay in the primary grades all your life you will never learn much. Likewise, weights and measures, and scales and balances are only the A B C of the weights-and-measures field.

In Massachusetts we have gone ahead. We have, only within the last year, changed the name of our department from "weights and measures" to the "department of standards." In other words, we are trying to rival the Bureau of Standards. We have gone into similar activities, as Dr. Stratton told you this morning. We have added a large laboratory, in which we have physicists who are working out scientific problems as well as practical problems. If you go into scientific work, gentlemen, always remember the practical end of it.

We have started in, as possibly some of you know, on thermometers. We test the clinical thermometers and any other kind of thermometer submitted to our office for test. Under a law in Massachusetts no clinical thermometer can be sold or offered for sale unless tested by our office. In tests that we recently made it may surprise you to know that in one city we rejected nearly 50 per cent of clinical thermometers offered for sale. In fact, in many institutions, State and city, the rejections have been all the way from 25 to 35 per cent. The trouble was largely with what we call the "retreaters."

We have also done a great deal of war work, and we are ready to go into the textile end of it. My plans are all laid, as we get larger appropriations for textile work. We expect as soon as this Bureau establishes the standard of gasoline to go ahead on that. I understand that the Bureau of Mines has practically completed these specifications. Next year, if this is feasible, perhaps we will have standard gasoline. We have a bill before the legislature in Massachusetts to fix standards of anthracite coal in Massachusetts. This 
bill will undoubtedly go through, as it has passed the first two stages at the present time.

As I was telling Dr. Stratton, I am soon going to start in testing all dry or liquid measures far more accurately than we do at the present time.

I think my five minutes are up, but I will tell you more this afternoon, as I understand I am on the program.

\section{MICHIGAN.}

By FrED L. WOODworTH, State Superintendent of Theights and Measures.

The Michigan treights and meaures law was passed six years ago. Prerious to that time there was no law on the subject, although five cities-Detroit, Grand Rapids, Saginaw, Flint, and Port Huronhad local ordinances and city sealers.

Our act builds up an enforcing organization with the food and drug commissioner, who is ex officio superintendent of weights and measures at its head, and depending for its field work on county and city inspectors who may be appointed by county boards of supervisors and city councils.

Up to date only about one-half the people of the State are served by such appointees. We have tried to do considerable educational work to encourage the appointment of county sealers, and several more have been appointed as a result. We have also tried to encourage a demand for a law that will make the appointment of a county sealer mandatory.

At present the Michigan food and drug department has three men who work on scale inspection all the time and seven who examine counter scales in connection with food-inspection work. In the past year one of our regular scale men has visited every county and city sealer and in most cases spent considerable time with him. We have also tested and sealed all new and many of the old weights used by the county and city sealers. In the counties that have no local sealers we try to get to each scale once a year.

The greatest shortcoming in the scale-inspection work in Michigan is on wagon scales. I think I am making a conservative estimate when $I$ say that wagon scales are used in transactions involving 60 per cent of the money that changes hands over scales. The delays in transportation, together with the excessive cost of draying, make it impracticable for the inspector to take heavy weights with him on railroad trips. To meet this situation, we are equipping a motor truck with the necessary outfit and will try to reach the wagon scales that have been neglected heretofore.

The last two legislatures have added greatly to the duties of the food and drug department: It has grown since I have taken the office from 26 employees to 101 . Some of these additional duties are, Te hope, of a temporary nature. When Federal prohibition goes into effect next January, we shall be able, and expect, to add considerably to our weights and measures department.

Michigan needs one State inspector of weights and measures for, roughly speaking, each congressional district in addition to local sealers. To head this organization I have selected Mr. A. A. Greer, of Port Huron. Mr. Greer is one of the most experienced and suc- 
cessful weights and measures officials in the State. I am sure that under his guidance the work will be a great success.

As in most institutions, public and private, our scale work has been somewhat upset by war conditions, but, like almost everything else, it promises to come ont of the ordeal stronger and more active than before.

Mr. BarNard. Mr. Chairman, I move that we now take a recess for lunch.

(The motion was seconded and agreed to.)

(Thereupon the conference took a recess until $2.30 \mathrm{p}$. m.) 


\section{SECOND SESSION (AFTERNOON OF WEDNESDAY, MAY 21, 1919).}

The Conference reassembled at 2.30 o'clock p. m., Dr. S. W. Stratton prasiding.

\section{REPORTS OF STATE DELEGATES-Continued.}

MINNESOTA.

By G. H. Staples, Inspector of Weights and Measures.

Minnesota has not progressed as rapidly in the past two years as it had for six years previous to that time, owing to the fact that the legislature reduced the appropriations to such an extent that one-half of the force had to be laid off. At the present time, however, Minnesota is in much better shape than it has been during the past two years. The legislature has increased the appropriations and raised the men's salaries so that after July 1 the work will progress much more rapidly than it has in the past two years.

NEBRASKA.

By LeO STUHR, Deputy Commissioner of Weights and Measures.

In Nebraska we have a food, dairy; drug, and oil division. Weights and measures is one of the subjects that is handled by this division. We have six inspectors for this line of work. Some of the work is handled by the drug men.

At the last session of the legislature there were several new features added to the weights and measures law. One of them was the section providing for the licensing of slot machines, and one was placing everything on a weight or numerical count basis. The legislature also passed what is known as the code bill in Nebraska, which will put the food, drug, and oil division under the department of agriculture. Up to this time the food, drug, and oil division has operated directly under the governor. It is a very large department handling all these various subjects.

The work of the weights and measures section has been limited practically to the testing of scales, with the exception of track scales. We do not handle any other line of standards, and this work is progressing in good shape. The entire division is operated upon the fee basis, so that there are ample fees collected to take care of all the work in good shape, and we expect to make a very good showing in the next report.

\section{NEW HAMPSHIRE.}

By H. A. WeBster, State Commissioner of Weights and Measures.

This is the first time that New Hampshire has been represented at once of these conferences by its State commissioner. The establishment of a State weights and measures department had been strongly advocated at several sessions of the legislature by Maj. James F. 
Brennan, who at one time was sent to one of the conferences as a representative of New Hampshire; but it was not until April, 1917, that there was established a weights and measures department in New Hampshire. The passage of the bill then was due to the persistent efforts of Gov. Keyes (now our junior United States Senator), members of his council, and a few members of the house and senate. The governor took the position that a bill of this sort, which had been passed in the house by a 3-to-1 margin at two previous sessions, should not be killed in the senate.

New Hampshire had been, prior to the passage of this act, about the only State in the Union which did not have some sort of protection in the matter of weights and measures, and the lack of such protection, it was estimated, had cost the people of New Hampshire nearly a million dollars a year, for this State had been the dumping ground of fradulent devices for the whole of New England.

It was estimated that in one of our cities the loss to the consumers throngh short weights was 4 cents on every dollar spent, but the inhabitants of this city, in common with the other citizens of the State, realize that they are no longer paying tribute to unscrupulous dealers and that they are no longer contributing nearly a million dollars a year due to fraud, of which they were the victims. New Hampshire no longer has the reputation of an "easy-mark" State, susceptible to such imposition as no other State in the Union tolerates. The law protects the purchasing public, which includes every consumer in the State.

After my appointment as commissioner of weights and measures, I spent several reeks at various State departments for the purpose of familiarizing myself with matters pertaining to the management of a department. I came to Washington and spent a week with the officials here at the National Bureau of Standards. The instructions which I received from the various State commissioners and the Federal officials in Washington have been very valuable. During the first week of July, 1917, I appointed three State inspectors of weights and measures. Let me assure you that I used the utmost discretion in the selection of these men, for I fully realized that the department would be judged largely by its representatives, and I have been equally careful in making recommendations of men who have been candidates for the position of city sealer in the various cities. There are at the present time seven city sealers in the State.

The people throughout the State are taking great interest in the work of the department of weights and measures. The department has endeavored to enforce all the weights and measures laws, but it should be stated that we have made a clear distinction between an intent to defraud and carelessness. There have been many persons prosecuted who have been guilty of violating various sections of the law, more particularly those pertaining to the sale of coal, wood, and ice. The original weights and measures law was amended at the recent session of the legislature in such a way as to make it compulsory to sell wood for fuel purposes by definite measurements.

The Government test car has been in New Hampshire, and all the important railroad track scales have been tested with a load of 80,000 pounds.

There has been placed in every mercantile establishment in the State a large commodity card giving the weights of 1 bushel, 1 
peck, and 1 quart of certain vegetables as provided by the laws of New Hampshire. A standard barrel for fruits and vegetables has been defined. Copies of the weights and measures law have been sent broadcast in order that the public might be familiar with the provisions of the new act. I have issued a pamphlet defining the tolerances and specifications for weights and measures and weighing and measuring devices. The second edition of Household Economy is nearly exhausted. This is a booklet containing valuable information for the housewives of New Hampshire. And let me emphasize this, that the efficient management of the household is materially enhanced by the exercising of due care on the part of the housewife in the weighing and measuring of the various commodities purchased, and it should be the duty of every woman who is responsible for the culinary department of the home to compare every day the weights and measures of commodities delivered with the quantity charged or paid for.

The domestic science teachers in the State have ordered copies of this book for their pupils. In fact, school superintendents have considered this subject of such importance as to have it introduced as a special course in the schools of New Hampshire. Apart from their direct results, measurements in the household are, when properly made, of educational value.

The picture in our report of confiscated articles shows the material which was being used intentionally and unintentionally by the dealers of New Hampshire. An enormous saving to purchasers of all commodities has been brought about by the purchases which have been made with accurate scales in contrast with those shown in the picture. Three thousand and fourteen scales, weights, measures, and weighing and measuring devices have been confiscated by the department during a period of one year, and this does not include 2,503 scales, weights, and measures which were condemned for repairs and afterwards reinspected and sealed by representatives of the department, or 6,041 scales, weights, measures, and automatic pumps which were adjusted before being sealed.

The satisfaction that consumers feel by reason of these accomplishments is also shared by the honest dealer, who, as he reads our report, will undoubtedly feel that his particular business, together with all others in the State of New Hampshire, is now on a more equitable basis. This would not have been the case had the previous competition continued with dishonest dealers who used fraudulent devices and who sold commodities which were underweight.

It seems to me that there is no question affecting the commercial relations of the people of any State upon which everyone agrees with greater unanimity than that the giving of short weight and measure is a grievous wrong and detrimental to sound business principles.

\section{NEW JERSEY. ${ }^{1}$}

By Frank Wanser, State Superintendent of Weights and Measures.

Mr. Chairman and gentlemen, in New Jersey we have a live, working State organization consisting of 60 members, comprising

\footnotetext{
1 This report, prepared by Mr. Wanser, was read by Mr. A. W. Schwartz at the former's request.
} 
the State, county, and nunicipal weights and measures force of the State.

When I was inducted into the weights and measures department something over two year's ago, an early meeting of this association was called and the same loyal support was pledged to me that had been accorded to $\mathrm{Mr}$. Waldron, my predecessor, and the slogan of "Watchful action" was adopted; both the pledge and slogan have been lived up to fully, and, it is needless to say, they have been productive of mighty fine results.

At our last two annual conventions the New Jersey. weights and measures laws were freely discussed by members of the association; amendments and new laws were suggested; these suggestions were taken up with the attorney general's office of our State; the entire laws wele gone over very carefully, section by section; and amendments were prepared to cure the defects and new bills drawn to cover essential points that seemed to have been overlooked, with the result that important constructive and corrective weights and measures legislation was enacted by the legislatures of 1918 and 1919.

One of the important acts passed in 1918 was a law making it mandatory that when certain commodities were sold by dry measure they must weigh a certain specific number of pounds. This law has worked out well. Many merchants throughout the State have discarded the dry measures and are selling by weight entirely, both the merchant and consumer thus becoming gradually educated to the sale-by-weight idea, so that we do not anticipate much serious opposition in 1920 when we purpose having a sales-by-weight law introduced.

It was our intention to endeavor to have such a law passed in 1918 , but, owing to opposition by some of the members of our State board of agriculture, a compromise was made, resulting in the existing law, on the theory that "half a loaf is better than no bread," and it has proven, as we anticipated, a step in the right direction.

Other measures passed in 1918 were corrective legislation, such as: Perfecting the Net-weight Container Act; requiring that all weights and measures used in trade in the State be tested and sealed at least once each year; requiring county and municipal superintendents to make monthly as well as annual reports to the State department; extending the time allowed for an appeal from two to ten days; putting teeth in the violation act; and last, but not least, increasing the salary of the State superintendent from $\$ 2,500$ to $\$ 3.500$ per annum.

In this connection I am proud to be able to make the statement that at least 80 per cent of our counties and municipalities have shown their appreciation and recognition of the valuable work accomplished by their weights and measures superintendents by awarding them substantial salary increases during the past two years.

The 1919 session of our legislature treated us as fairly as that of 1918, passing a bill requiring all ice to be sold by weight; a bill (hanging the method of procedure in bringing suits under the netweight container act; a bill fixing penalties for giving short weight or short measure; and a bill correcting the tenure-of-office act.

Our department feels that, with what has been accomplished in the way of legislation, when a sales-by-weight law has been enacted 
we will have a mighty good set of practical working laws, the only thing needed to complete them being the passage by Congress of a national law requiring uniform standard containers.

The New Jersey department is now on a practical business basis. It has been, and is our policy, not to persecute, but when violations are flagrant there is but one course to pursue, and that is to prosecute. For instance, late in 1917, investigation showed that there was gross short-weighing by coal dealers. A State-wide campaign was inaugurated, and during the fiscal year which ended June 30,1918, covering a period of but eight months, the fines paid by coal dealers aggregated $\$ 2,797$. That this heroic treatment proved beneficial is evidenced by the fact that for the past 10 months the fines from this source have been only $\$ 510$, while the reweighings have been even more frequent than during the period mentioned.

For the past two years the work of the superintendents has been particularly arduous, for, in addition to their regular duties, which have not been neglected, the entire department has cooperated fully and freely with the fuel and food administrations and with the exemption boards, and it is with a great deal of personal satisfaction and pardonable pride that I can point to the fact that the entire force has always cheerfully, willingly, and promptly answered every call made upon it in connection with war movements.

In conclusion, I might add that, owing to the whole-souled and hearty cooperation of our county and municipal superintendents with the State department, weight and measure conditions are in very good shape in New Jersey.

NEW YORK.

By W. T. Wніте, Director of the Burcau of Weights and Measures.

Since I was appointed to my present position as recently as the $22 d$ of last April, I am not able to give an intelligent report on the work that has been done by the State department of New York. I will say, therefore, only that I am glad to be here and to meet the gentlemen from the other States.

OHIO.

By JoHN M. Mоте, Assistant Chief State Inspector of Weights and Measures.

The State of Ohio has made great progress in weights and measures work; and we feel that public opinion now is greatly in favor of such protection-more than ever before.

We are extremely proud of the activities and interest manifested by Ohio weights and measures men in devoting their time and assistance to the enforcement of Government food regulations during the great World War and the effort which they made to protect the public against the many frauds which so commonly appear in war time.

The present session of the Ohio Legislature has just enacted two laws on weights and measures that we believe will be a great step forward in protecting the pocketbook of the public. One of these was the standard-container act, which is almost a copy of the pro- 
posed Federal law regulating the size and dimensions of hampers and baskets which are manufactured or used within the State. The other bill was what we call a net-weight-sales law, which is designed to prohibit the meat packers' practice of wrapping an excessive amount of paper around the meats sold to dealers and weighing this clieap grade of paper in at the price of the meat contained in the package.

Another section of the bill compels dealers to plainly mark net contents on containers filled with liquid commodities. What was probably the greatest activity of the State bureau of Ohio during the past two years was the crusade made against retail oil companies in the city of Cleveland, Ohio. For a number of years it has been a common practice for many of these firms to overgauge the shipments of lubricating oils sold, and the practice became so bold that many of these firms were charging for 34 and 35 gallons of a commodity when the actual capacity of the barrel or drum was but 30 gallons. Up to the present time 17 of these companies have been prosecuted by the State, and some of them have made refunds to their customer's which totaled many thousands of dollars.

Under the law just enacted by the Ohio Legislature, these companies will face a $\$ 500$ fine in case a fradulent mark as to the net contents is placed upon the package; and once this task is completed we believe that we can safely say that the Ohio weights and measures bureau has saved the public from being defrauded of many thousands of gallons of oil every year.

We beliere that the regulations now in effect pertaining to scales meet all of our requirements, while the regulations and the reports of inspectors clearly indicate that some steps should be taken to more fully protect the public against the inaccuracies of automatic measuring pumps.

Within the past two years our department has been confronted with rather perplexing problems as to interstate shipments found to be short in weight. In most instances we were forced to depend upon the honesty of the shipper to make adjustment of such interstate shipments, and we beliere that there should be immediate Federal legislation along this line.

Through the great number of exhibits held by the State bureau we have started an educational campaign that creates unusual interest and awakens the public mind to the fact that our work is a most worthy one, and the support given us by the press clearly indicates that Ohio is going forward in the battle for honest weights and measures.

I am pleased to say that four county sealers from Ohio are here to-day.

PENNSYLVANIA.

By JAMEs SwEEnex, Chief of State Bureau of Standards.

Mr. Chairman and gentlemen of the convention, I have the honor to represent the great Commonwealth of Pennsylvania, a State which has always taken an advanced position on all questions that concern the welfare of its people. Its legislation has ever been of a character looking to the conserving of the interests of the public. 
With this view, its statesmen saw the need of the enactment of legislation which would protect its people from those who were inclined to increase their profits by defrauding the public by giving short weight and measure. This law has been in existence but a few years. Under its provisions every county and city has one or more inspectors of weights and measures, and the faithful way in which these inspectors perform their duties has made the office of inspector of weights and measures one of the most important in our Commonwealth, and the public has come to regard the inspector as the guardian of their interests. When a commodity is purchased, they feel safe that they are receiving the full amount for which they pay. This is true of commodities that are sold in package form or containers of any kind, as well as those that are sold over a scale or in a measure. Every package is inspected, and when the contents in the package or container is less than is indicated on the outside thereof the inspector forbids the sale of the package or container, and if the merchant neglects to comply with the warning given him he subjects himself to the penalties imposed by the act of assembly.

Since the work of inspection of weights and measures began in 1912 the total inspections up to and including 1918 of measuring and weighing devices have been $2,542,120$, the total number condemned or confiscated being 262,774 , thus forever removing from use devices that have been used as a means to defraud purchasers.

In addition to the inspection and confiscation of weighing and measuring devices, there were inspected $2,608,165$ packages in which commodities were sold, of which 136,659 were condemned, as they did not contain the quantity that was indicated on the outside of the package.

During the war period the inspectors devoted a large part of their time to assisting the food administrators in enforcing the regulations imposed by the Federal authorities, that our boys over there might be given the proper food that would enable them to continue the struggle for a world democracy, all of which proves conclusively the great importance to the public of the weights and measures legislation.

\section{RHODE ISLAND.}

By Wrulam F. Goowwin, State Sealer of Weights and Measures.

Mr. President, delegates, and guests, I want to say that I am pleased to be with you to-day. I did not expect to be here, but at the last moment I was talking to the secretary to the governor, and he thought that it would be advisable for a delegate to attend. I am going to confine myself to as few remarks as possible, because I desire to give my neighbor from Massachusetts the opportunity of having more time. But I want to assure you, gentlemen, that the organization of weights and measures is doing good work in Rhode Island, even during these strenuous times. Rhode Island almost always goes over the top when she starts anything, and she is still holding her record. In the two years since we last met here we have passed some special legislation in Rhode Island in the interests of weights and measures, and I wish to say that $I$ have been given a small appropriation and am thankful for it. 
I am glad to see so many old faces here. I deplore the fact that my dear friend Connors is not here. I miss his presence to-day. He was a valuable man and always a good friend. I deeply appreciate that fact and deplore his loss.

Gentlemen, I do not know that there is anything I can say further that will interest you.

\section{SOUTH CAROLINA.}

By H. W. McCreight, Chief Clerk, Department of Agriculture, Commeree, and Industry.

I have the honor to represent the State of South Carolina at this important convention. The department of agriculture has a good many things to look after, including weights and measures. It is also delegated by the State legislature to regulate the inspection of feeds, foods and drugs, gasuline and kelosene, and factories, and has quite an up-to-date laboratory. We have about five inspectors, not entirely on weights and measures, but their duties also inclurle that work. We are not dependent upon State appropriations in this work, and are not thus handicapped, as many States here represented are. We maintain the department from the receipts of funds derived from inspection fees on feeds, oils and seeds, food and drugs, and gasoline and kerosene, and turn in about $\$ 25,000$ to the State treasury.

In 1913 the legislature at its session enacted a law on weights and measures, and this has been amended from time to time. The work is proceeding satisfactorily, and we feel that now, in this time of war and the high cost of living, much depends upon giving the people accurate weights and measures, and we are giving close supervision to that matter now.

This department has for years promulgated and distributed bulletins free of charge containing reights-and-measures laws, also a list of various agricultural commodities and articles of food with the corresponding official weights. The department now employs eight inspector's having authority to inspect weights and measures. South Carolina is constantly on the alert to keep up with these progressive times, being prompt to adopt new laws and amendments with this object in view. We hope to progress and keep up with the other States and at the next session of the legislature, which is annual, we hope to revise the law somewhat.

The Chalruran. The last speaker, Mr. McCreight, has mentioned a point of much interest to us. We find so often that the weights and measures affairs are administered in connection with the food and drugs acts and matters of that kind. That may be necessary in a good many places. We feel that the weights and measures work in most cases is sufficiently important to be handled by itself, but in case those two fields are combined it ought not in any way to destroy your interest in the weights and measures work as such and your relation to this organization. It is a great mistake to assume that because these things are administered by some other department of the State you can not keep up the same connection and do just as good work as if you were in a department by yourselves. 


\section{SOUTH DAKOTA.}

By ANTON RunBeck, State Inspector of Weights and Measures.

Our last legislature passed a weights and measures law, going into effect July 1, the enforcement of which is in the hands of the food and drug department. In our department we have to do the best we can. We have no experienced men in technical scale work and only a very limited appropriation with which to go ahead.

TENNESSEE.

By T. F. MAHONx, County and State Sealer, of Chattanooga.

Mr. Chairman and gentlemen, since the organization of weights and measures work in our State we have progressed greatly. Of course, a great deal of this is due to the Bureau of Standards in giving the sealers advice. The adoption of the national law in 1914 has also enabled us to be more efficient in our work.

I have one suggestion to offer, which is not intended as a reflection on any official. Our superintendent of weights and measures is an ex officio official, being primarily food and drug commissioner. Now, I think, if the food and drug commission were made a separate office, and the weights and measures department were made a separate one, we would have more success in our work and more county sealers throughout the State. As it is now the appropriation for the combined departments is $\$ 20,000$ for two years. There are six deputies to take care of the food work, but weights and measures matters are neglected. I went into Bradley County, which adjoins Hamilton County, and in 10 stores I found bottomless measures, and every man knows that this is the crookedest measure on earth. There is also a great deal of wildcatting of second-hand scales throughout districts without sealers. I wrote Gov. Roberts of my findings and also the superintendent. Now, I think that we would get better results if the weights and measures department were under its own head.

We have only 6 sealers in the State of Tennessee when we should have at least 26 . I am endeavoring to organize the sealers of the State, and am going to take this up after my return home.

This concludes all I care to say at this time, as my purpose in attending the convention is to gain knowledge. I guarantee you that in the future Tennessee will be the banner State of the South as far as weights and measures is concerned.

\section{TEXAS.}

By D. A. GREGG, Deputy Superintendent of Weights and Measures.

Mr. Chairman, I really have nothing to report as to the acticities of the weights and measures department of Texas, since for more than 70 years we have had practically no system of inspection of weights and measures. Some of the delegates this morning referred to their States as States, and some of them as Commonwealths. I believe I could refer to Texas as an empire. Texas, as you know, was 
once an independent nation. It came into the Union voluntarily, and since that time it seems that one of the most important things that affect the economic life of that State has been overlooked. I had the honor to serve the people of Texas in another capacity for a. good many years, and at that time my attention was called to the necessity of weights and measures legislation, and I studied the matter to some extent. I went out of that position into private life, but was called back as chief clerk and attorney for the markets and warehouse commission, and I began a study of the question again. I soon determined that no marketing commission could be successfully carried on without a well-regulated system of weights and measures and adequate laws to put it into effect, and consequently I called the attention of the legislature to this omission. I was delegated to write a law. The law was written and introduced. With some slight amendments in the committee, prescribing the units of weights and measures, a general weights and measures law was enacted without discussion, and without amendments, which is rather remarkable for a Texas legislature.

I beliere we have at least the starting point for a well-founded system of inspection of weights and measures, and, gentlemen, I hope that at the next conference I will be able to report satisfactory progress along these lines. The legislature of my State has given us $\$ 20,000$ with which to organize this department. It is our purpose to put 50 inspectors in the field. Of the city sealers some 50 or 75 became State sealers. The power of appointment is not taken away from the city, but they have to work under the direction of the State supervisor of weights and measures, which will gire us a force of something like 100 to 125 men. Eren this is hardly sufficient, I realize now, because Texas has 254 counties, some of which are larger than some States that are here represented. We hope to make satisfactory progress, howerer, and I feel satisfied that with the unanimous support of our Texas Legislature, we can get practically anything that we want. I want to receive suggestions from the Bureau of Standards and from those who have successfully conducted their departments in the different States of the Union.

UTAH.

By T. L. Invine, Inspector of Weights and Measures.

Mr. Chairman and gentlemen of the convention, I suppose I represent a cow country in the West, but I am pleased to be here and take part in this conrention. I believe this is the second time that the State of Utah has been represented at the Bureau of Standards. Some four years ago, or a little more, I was appointed city inspector for Salt Lake City. We had practically no law, at least the law was inadequate, and, after having labored under that condition for some time and seeing the necessity for better legislation, I communicated with the Bureau of Standards. They immediately wired Mr. Holbrook, who was then in Arizona, and he came to Salt Lake City. and met our governor, who was mayor at the time. I was given a free hand to lobby a bill through the legislature. It was some lobby. After 60 days, when there were only a couple of 
days of the session left, we finally got our bill through, just about as Mr. Holbrook and the State commissioner and I had outlined it. I believe it went through with just one amendment.

I think we have a weights and measures law that is practically up to date, except that the State dairy and food commissioner is ex officio superintendent of weights and measures, and we have the same trouble our friend from Temnessee has. They devote more attention to the food and drug work than they do to the weights and measures work, and the State is suffering on account of that. I am a firm believer in having a separate department of weights and measures. I believe the work is so important it should be a separate department in every State, and I believe it is so important that sufficient money should be given to the department to carry out the work in a successful manner.

I do not know that I have any special report to make, except that we are jogging along in our quiet way, endeavoring to make the people be good, if they are inclined to be otherwise, although I believe 90 per cent of the people who are doing business are honest. I came here for information more than to give information, because I do not have sufficient knowledge to dispense any information to a body of this kind.

The Cramran. I am very glad to hear the gentleman express himself as he has. Without in any way detracting from the importance of the food and drug work-because it is a really important matter-I have felt that when the weights and measures officials come to take up all those things that they surely will in time, then this whole subject should be removed from the other, since it calls for an entirely different class of experts. That is the reason why $I$ hare that opinon.

VIRGINIA,

By C. H. MorRissetr, Secretary of Board of Legislative Research.

Mr. Chairman, this is my first visit to this conference. I was asked by the governor of our State to come up here mainly for the purpose of securing sufficient information to enable one of our boards in Virginia to draft a modern weights and measures law. Virginia, being one of the older States, has for a long time had a law on its statute books, but it is antiquated and not enforced to any great extent, although more so than in some of the other States. The Constitution of the United States says that Congress shall have power to fix the standard of weights and measures. Now that power would enable Congress to pass any law on this subject which would put into force and operation those standards which are fixed by the Congress.

It has occurred to me that, instead of the States going about and regulating these matters, it would be much better if the Congress of the United States could be prevailed upon to pass a comprehensive weights and measures law, in order to make it absolutely uniform throughout the Nation. That law could be enforced by State inspectors, if necessary, or by the inspectors of the Federal Government. We have laws on our books. Most of the States have laws on their books to-day which are absolutely of no force and effect because 
they are in conflict with the laws of Congress, an act of Congress being supreme over the land. Now, I would like some of the members of those States having model weights and measures laws to let me know if I can get copies of them to help our governor in drafting a law for Virginia.

The Chamman. The last speaker has touched upon a very important point, the question of national laws. Of course, I think he will concede that it would be unwise to draw up a national law having to do with local inspection. There is quite a considerable amount of national legislation that should be taken up, however, and it would be well for this conference to consider such legislation in order that the Bureau may go to Congress with the indorsement of the conference. Furthermore, there are a great many things in regard to which we need uniformity, and it would be well for you to consider from time to time the question of issuing standard regulations regarding certain matters. In such cases, the Bureau would be pleased to use them as Government publications, which could be copied by the various States. A great deal could be also done to bring about uniformity by getting together and adopting uniform legislation regarding local matters.

\section{WEST VIRGINIA.}

By G. B. STEWART, State Inspector of Weights and Dreasures.

I will say that I am glad to have the privilege of being with you, and I am glad also to have the privilege of representing the Commonwealth of West Virginia. We are making progress in West Virginia along the lines of weights and measures. In the last two years we have made some advanced steps. First, while we do not require everything to be weighed now, practically every commodity that is sold in bulk in the State is based on the standard bushel. We have also a law on our statute book, passed in the last legislature, wherein a justice of the peace has the right to try and determine a case. Heretofore, we had to go before a jury, and we have found by past experience that when you bring a case before a jury, if there is an ounce variation on a pound of butter, the farmer does not think this very much. He does not realize that this amounts to several hundred pounds a day perhaps; and it was very hard for us to get a conviction. However, I have lost but one or two cases in the State. That has been our trouble, but since the present commissioner of weights and ineasures has been in office we have been making very rapid strides.

As you know, in our State we have a great many coal mines. In the last year we prevented or settled something like 42 strikes. We find that the department of weights and measures has been of value in the State in various ways, but the greatest thing I have to tell you to-day is that the general public of the State is lining up behind us and is now helping us. The Wholesale Grocer's' Association-I was just in conference with them the other day-said that from now on they will help is to get through anything we desire. We feel that the people are waking up to the value of weights and measures work. 
WISCONSIN.

By Ralph W. Smith, Chief State Inspector of Weights and Measures.

Mr. Chairman and gentlemen, I was not advised that the secretary wanted a written report, so I prepared none. I think that all of you are, perhaps, familiar with the work Wisconsin has done along the weights and measures line. When I came to the State, I found a very efficient organization, and I found an efficient and valuable set of statutes and regulations, so that my work consisted largely of attempting to carry on the work which was started. I feel that we are doing much in a fair sort of fashion; but there is one part of my work with which I am not satisfied, and I am going to mention it at this time because I am in hopes that I can take back with me some definite regulation on this subject-that is the question of oil pumps. It is the most trollblesome question I have to contend with at the present time.

The Chamman. I hope you will insist that our weights and measures department give you satisfaction before you leave. After we get well started, we have specifications on liquid-measuring pumps that will be discussed. By your experience you will decide whether they should be adopted or not.

We have finished the list of States. I note we have here a number of city officials from States not officially represented, and as it will take but a few minutes I would like to hear from at least one delegate from these States. There is a representative here from the city of Portland, and I would like to hear what Maine has done recently along weights and measures lines.

\section{REPORTS OF DELEGATES FROM OTHER STATES.}

\section{MAINE.}

By Augustus F. Bore, Sealer of Weights and Measures of Portland.

I have not much to say, since my experience has been very short. I was elected by the city officers in the month of May, 1918. In December I filed a report, and I called the attention of the mayor to the fact that we did not have enough weights and measures laws in the city $\oplus r$ in the State. I was directed to call it to the attention of the State sealer.

I think it will interest this convention to know that we passed a law in the Legislature of Maine last February to the effect that no scale should be offered for sale, sold or used, unless it is approved by the Bureau of Standards in Washington. I think this is a very good law and that the State of Maine did well to pass it. I think the Bureall of Standards favors such a law. That is all I have to say.

\section{NORTH CAROLINA.}

By G. C. Smmons, standard Keeper of New Hanorer County.

We have no regularly appointed representative from North Carolina; so I have as much right to represent that State as any other. We have a very good law on standards and have 75 inspectors in North Carolina. Several colnties in the State are governed by special acts of the legislature, and they are getting along very nicely. 
I have for the past four year's been trying to organize the State of North Carolina by counties, since we have no State force. We need some new laws. I think that in the next two years we will have an organization of the counties and have annual meetings. Then we can suggest to the legislature of the State any law we see fit and have the strength to pass it. I think that is all I have to say.

\section{DISCUSSION OF FEDERAL APPROVAL OF TYPE OF APPARATUS.'}

The Chairman. Referring to the remarks of Mr. Bove, I think he was entirely right in his attempt to put that through. There is no such national law. There ought to be, but the fact is that it has not as yet been enacted. I think that of all the legislation that has been proposed in connection with weights and measures a national law along these limes is the most important, and there should not be the least objection to it. Much to our surprise, we find a lot of foolish opposition every time it is brought up. One argument which has been urged is that the Bureau of Standards would take that opportunity to require apparatus to be in the metric system. Of course, we would not do so, nor would we have any authority to do so. There should not be any device used that is not accepted by experts as being proper.

Mr. Bove. May I be permitted again? When we passed that law last February, it was at first provided that such tests should be made by the sealer of weights and measures of the State of Maine, and then suggested that the State sealer, perhaps, did not have the experience that the Bureau of Standards had, and it was accordingly changed on that basis. I appeared before the committee in favor of it. I had to condemn 75 out of 100 scales in the city of Portland. That is why that law passed. Maine was the first State in the Union to pass that law.

Mr. Goodwin. I believe the gentleman has the right idea. Any scales that do not pass the test of the Bureau of Standards ought not to be allowed to be sold in this country. I think the proper thing for any scale manufacturer to do is to send his scales here and have the Bureau of Standards pass on them.

Am I right in my impression that the Ashbrook bill, considered at a previous conference, covers this question?

The Chairman. Yes, indeed.

Mr. Goodwrs. It has the sanction of this Bureau?

The Chairman. It has been approved by this conference.

Mr. Mikeselr. Is the bill still pending?

The Chatrman. It will be reintroduced. The bills all die when Congress dies. This is the beginning of a new Congress.

Mr. Mikeselz. I fully understand that, but I meant the intention is to follow it up?

The Chairman. It is, so far as the Bureau is concerned.

Mr. Mikeseld. That is what I meant.

Mr. Tucker. I have a reason why it is necessary for the Bureau of Standards to verify whether the type of scale would stand a rigid inspection. There was a make of scales we had not come across in the State of Indiana and we wished to know whether they should

\footnotetext{
1 See also paper and discussion of this subject on pp. 134-139, and resolution on p. 205 .
} 
be allowed to come in. If it were so that the different scale firms of the United States would have to submit their specifications to the Government, we could get information immediately on such questions.

The Chairman. I think that there will be no difficulty in getting the Bureau to pass upon them. It is the question whether our objection would prohibit much of itself. You would have to be backed up by your laws. As matters stand, you yourselves would have to take the responsibility of prohibiting the importation and sale.

Mr. Tucker. A scale that would not be approved by the United States Bureau of Standards should not be allowed to enter into interstate commerce.

The Chairuan. Under present conditions we would simply serre as your advisers.

Mr. GregG. On that particular subject I want to ask a question of interest. Could not objections of manufacturers and of Member's of Congress who oppose this bill be eliminated by limiting the approval to the type instead of to the individual scale? Have the type approved by the Bureau of Standards.

The Chamrinan. The proposed legislation refers only to type. I presume that ample opportunity will be given for discussion of this subject as we progress along the program.

Mr. Steinel. At this time I would like to make a suggestion, after listening to these various reports and seeing new States represented here. I would like to have the chairman instruct the secretary to furnish us with a list of the States represented here this year, because when we get home the first question that is asked is, "How many States were represented?" If you can give a table of that kind showing how the work is growing it would be rery useful. It could be compiled easily and given to all the members before we go.

The Secretary. We certainly could give him what he asks for.

The Chamrian. We can give a list of names, papers, the text of the resolutions passed, etc.

Mr. Hanson. I think it would be well to get the names and addresses of every one here.

Mr. Steinec. Possibly those who are not represented; it wonld bring them into the organization of weights and measures.

Mr. Mikesel.. I think that is gotten out by some of the boys here, who always prepare a list for us. We always get the list. I have already asked Mr. Holbrook to furnish a list of all those present, together with information as to whether they are delegates or guests. I think that is the list that Mr. Steinel speaks of.

\section{ADDRESS BY THURE HANSON, COMMISSIONER OF STANDARDS OF IMASSACHUSETTS.}

Mr. Chairman and gentlemen, while the subject assigned me was a résumé of the work done by the Massachusetts department during war times, I told the secretary that the allotted time for preparation was so short that I could not get all the material together. I will give you, however, a résumé of the work our department did in cooperation with the local sealers in enforcing the food regulations and also the coal regulations. 
During the months preceding the entrance of the United States into the late World War the export of foodstuffs from American ports increased tremendously. Whether the market be the whole world or a single city, delivery is a considerable problem and usually one of the chief items of expense. While there were huge stores of wheat in Australia, Argentina, and Inclia, the shortage of shipping eliminated these distant sources of production during the entire period of the war.

When our country entered the war in the spring of 1917, the food problem immediately became acute. In a few months approximately 2,000,000 men were inducted into our Army and Navy, reducing production and at the same time increasing consumption of food and other necessities. Food regulation became necessary in order that by eliminating waste and using substitutes the savable surplus might be sufficient to keep our Army and those of onr allies fit for fighting.

While the great majority were willing and anxious to cooperate in the conservation program of Mr. Hoover, there were, as usual, some slackers, some few who must always be policed to prevent them from confounding liberty and license, and it became necessary to appoint food administrators in the various States and to regulate sales of sugar, flour, meats, etc., by requiring dealers to be licensed and by suspending or revoling these licenses for violation of the regulations.

In order to secure the greatest degree of efficiency, it was necessary to have a representative of the Food Administration in every city and town. In other States it was necessary for the food administrator to build up an organization of volunteer assistants in the various cities and towns. Massachusetts has a sealer of weights and measures in every city and town, and when this opportunity for patriotic service was called to their attention there was a unanimous response. There have been numerous occasions when special information from a particular city or town was necessary or desirable. Invariably a request from my department to the local sealer for such information brought an immediate response. The ready response to all calls has been impressive, and the service rendered by the local sealers, in cooperation with my department, has been officially recognized by State and Federal authorities.

When the rules and regulations governing the manufacture of bakery products became effective on December 10, 1917, this alreadyestablished organization of weights and measures officials, acting as bakery inspectors, enabled Massachusetts to set the pace for all other States in their administration and enforcement. In order to facilitate the work and render the cooperation of the sealers more effective, my department issued a bulletin of 20 pages, containing the rules and regulations, instructions to bakery inspectors, etc.

I may say here that at the time the Food Administration questioned the advisability of making a uniform loaf to be sold throughout the country the Food Administration telegraphed to Massachusetts and asked if we had any data. Previously we had compiled data as to the weights of bread. A few days afterwards we received a telegram asking if it was possible for us to give the weight, selling price, etc., of bread made in Massachnsetts or sent to us. This telegram was received in my office about 4 o'clock in the afternoon and at 7 o'clock that night we had a circular letter put through a multigraph machine and sent out to all the city and town sealers. In a 
few days we had information from every corner of Massachusetts relative to the weight of bread, price, wholesale and retail, and all other information the administration wanted, and inside of seren days the information was down here at Washington.

While the Food Administration was emphasizing the fact that food was necessary in order to win the war, the Fuel Administrator was pointing out with equal emphasis that coal was needed to transport troops and supplies, to make munitions and other. war materials, and to keep our industries going. Coal dealers were licensed, shipments regulated, and prices fixed for various commodities. Our State inspectors and local sealers again materially assisted in enforcing these regulations and restrictions, while I supplemented their efforts by the publication of a special number of the "Thrift Series." calling attention to the importance of economy in the use of coal for cooking and other household activities; to the opportunities for intelligent substitution of other fuels, such as wood, kerosene, gas, and electricity; and to the practice of economy in selecting, cooking, and serving foods, showing how to eat plentifully and wisely without waste.

It should not be understood, however, that other activities of the Massachusetts department were at a standstill while carrying on the special work incident to the war. On the contrary, more than the usual amount of progressive legislation has been enacted in the years since the last conference, and the following summary may be of interest to those present.

Legislation relative to the work of my department enacted by the general court since the last conference may be summarized as follows:

Chapter 44, General Acts of 1916, authorizing the commissioner of weights and measures, with the approval of the governor and council, to establish district offices.

Chapters 48 and 242, General Acts of 1916, relating to licensing of hawkers and peddlers. The statute governing this subject was originally enacted in 1846, and, in the amendment of different sections since that time, there had been no attempt at a comprehensive revision of the entire statute. The result was an apparent conflict between different sections, and the enactments of 1916 were designed to facilitate the construction and enforcement of the law.

Chapter 120, General Acts of 1916, transferred the licensing of itinelant vendors from the secretary of the Commonwealth to the commissioner of weights and measures. The chief distinction between the "itinerant vendor" and the "hawker or peddler," as defined by the Massachusetts law, is that the former occupies a building or structure for a temporary or transient business, while the latter travels about from town to town, or from place to place in the same town. Upon the assumption of this additional duty by my department it was found that but three itinerant vendor's' licenses had been issued during the entire year 1915, the license fees amounting to $\$ 75$. In the first eight months my department issued 41 licenses, collected fees amounting to $\$ 1,025$, and successfully prosecuted three unlicensed itinerant vendors.

Chapter 151, General Acts of 1916, provides for testing and marking the capacity of containers, which are furnished by the purchaser 
of milk at wholesale upon petition of the seller to a sealer or deputy sealers of weights and measures.

Chapter 154, General Acts of 1916, requires that range boilers shall be marked with their capacity in terms of standard liquid measure, together with the maker's name, and that range boilers, or other vessels or tanks in which water is to be heated under pressure, shall have stamped thereon the maker's guarantee that it has been tested to not less than 200 pounds to the square inch by hydraulic or hydrostatic pressure, together with the maximum working pressure at which it may be installed.

Chapter 157, General Acts of 1916, amended the existing bread law so that it shall not apply to bread sold in wrapped or package form having the net quantity of the contents plainly and conspicuously marked on the outside of the covering or container.

Chapter 8, General Acts of 1917, amends the law providing for the testing of both weight and value indications upon computing scales, so that it shall also apply to any measuring device which purports to indicate the price as well as the amount of the goods offered for sale.

Chapter 13, General Acts of 1917 , relates to the marking of quantity of contents on closed packages of apples.

Chapter 14, General Acts of 1917, establishes a fine not exceeding $\$ 100$ as the penalty for violation of the statute providing that if commodities are solil by weight it shall be understood to mean net weight.

Chapter 15, General Acts of 1917, permits the sealer to give a certificate, in such form as may be approved by the commissioner, when sealing a pothecaries' weights or other weighing or measuring devices which are too small to be sealed in the usual manner.

Chapter 21, General Acts of 1917, requires the commissioner of weights and measures to establish specifications for graduated glass measures, and provides that he may authorize manufacturers of such measures to seal those which conform to samples which have been approved by him as complying with the specifications.

Chapter 98, General Acts of 1917, transfers the duty of testing and sealing taximeters from the commissioner to local sealers of weights and measures. Under the amended law the commissioner retains the power to make such rules and regulations as he may deem necessary to insure accuracy in the use of these devices and a penalty of $\$ 10$ is provided for neglect or refusal to comply with these rules or regulations.

Chapter 125, General Acts of 1917 , repeals the mandatory provision which required that city and town standards should be verified and sealed by the commissioner at least once in five years. It is now provided that this work be performed at least once in 10 years, or oftener if the commissioner deems it necessary.

Chapter 152, General Acts of 1917, establishes a State clinical standard thermometer and penalizes the sale or offering for sale in Massachusetts of any clinical thermometer which has not been sealed either by the commissioner of weights and measures or by the manlfacturer.

Chapter 237, General Acts of 1917, amends the itinerant vendors' license law so that it shall not apply to a temporary or Iransient sale 
in any city or town in which taxes have been paid upon the stock in trade during the current year. It also permits the commissioner to accept a bond in liell of the $\$ 500$ cash deposit formerly required of all applicants for these licenses.

Chapter 243, General Acts of 1917, increases the salary of the commissioner of weights and measures from $\$ 2,000$ to $\$ 2,500$.

Chapter 65, General Acts of 1918, provides for the appointment of local weighers, measurers, and surveyors of commodities in cities and towns upon petition of any person, firm, or corporation engaged in buying, selling, or transporting goods or commodities which require weighing, surveying, or measuring.

Chapter 218, General Acts of 1918 , provides that the commissioner of weights and measures shall hereafter be known and designated as the commissioner of standards and establishes his salary at $\$ 3,000$ per annum. The new title is sufficiently comprehensive to include all divisions of the departmental work, the scope of which had gradually broadened until the title of "weights and measures" gave but slight indication of the activities of this branch of the public service.

Chapter 22, General Acts of 1919, authorizes the granting of special licenses as hawkers and peddlers without fee to disabled reterans of the present war.

Chapter 63, General Acts of 1919, an act to prevent fraud in baling, or in packing in any container, any commodity sold by weight, including wool, leather, cotton, waste, rags, and paper, by placing any foreign substance in the package.

Chapter 91, General Acts of 1919, becomes effective January 1, 1920 , and amends the present law relating to the sale of coke, charcoal, and kindling wood. It provides that when edgings or kindling rood are sold in bundles the same shall be closely packed and not less than 27 inches in circumference; that unpacked kindling wood, except when sold in bulk by the load, shall be sold only by measure; and that baskets and similar receptacles used in selling coke, charcoal, or kindling wood by measure shall be 1 bushel or multiple thereof, shall have their capacity marked thereon, shall be sealed, and shall be filled at least level fill.

It also standardizes paper bags used in the sale of coke, charcoal. and kindling wood by measure, providing that their height shall be not less than 25 inches, width not less than $13 \frac{1}{2}$ inches, and width of bottom not less than 43 inches. These bags shall contain and shall be sold as containing one-half bushel and shall be so marked, together with the name and address of the party who puts it up, and they shall be filled to a point not more than 6 inches from the upper end. A fine not exceeding $\$ 50$ is the penalty for violation of the provisions of this act.

Chapter 218, General Acts of 1919, amends the law regulating fees receivable by sealers of weights and measures, providing a fee of $\$ 1$ for all scales with a capacity of 5,000 pounds; 50 cents for all scales with a weighing capacity of 100 to 5,000 pounds; 10 cents each for all other scales, balances, and measures on pumps; and 3 cents each for all weights and other measures.

There is also pending in the present session of the legislature a bill relating to salaries of inspectors in the department of stand- 
ards. This provides that salaries shall hereafter be fixcd by the heads of departments under authority of the supervisor of administration, subject to the approval of the governor and council.

Other, and perhaps the most important legislation now pending. relates to the consolidation of departments. Under the nineteenth amendment to the constitution of Massachusetts, submitted by the late constitutional convention and ratified by the roters at the last State election, it is required that every executive and administrative office, board, or colmmission, except those officer's serving directly under the governor or the council, shall be organized in not more than 20 departments on or before January 1, 1921. As there are now more than 100 such officel's, boards, and conmissions to be consolidated and combined into not more than 20 departments, the problem is a difficult one. Many tentative plans have been prescnted only to be discarded or modified a fter discussion. Some of these plans provided that the commissioner of standards should be placed in the department of the secretary of the Commonwealth, although there is little, if any, correlation in the duties and powers of these two departments. The latest plan suggested would establish a new department of labor and industry. combining the present board of labor and industries, board of conciliation and arbitration, minimum wage commission, free employment agencies, labor statistics and statistics of manufacture, commissioner of standards, and surveyor general of lumber, and board of elevator regulations, provision to be made for dividing the department into various divisions.

To many who have studied the question, a more logical combination would be that of the district police and the commissioner of standards. It is inpossible, however, at this time to venture any opinion as to what combination of departments will eventually be decided upon.

In addition to the new and progressive legislation included in the foregoing summary, chapter 43 of the resolves of 1916 provides for the appointment of commissioners to consolidate and arrange the laws of the Commonwealth. As a preliminary to the final consolidation, the legislature of 1918 made 21 amendments to existing laws by the enactment of chapter 257 of the general acts of that year, although these amendments do not become effective until February 1, 1920 .

Among other bills we have laid a bill before the legislature in Massachusetts standardizing coal. In this bill we have provided that the coal dealers shall be licensed in the same way that we license peddlers. Every peddler in Massachusetts is controlled from the State office. If the peddler is convicted for short weight, we do not go to court and get a fine of $\$ 5$ or $\$ 10$, but simply suspend or revoke his license, which has a better result. The bill relative to coal is drafted on the same principle. If a dealer in coal gives short weight, it is easy to bring him into court and fine him $\$ 5$ or $\$ 10$; but is that the desired result? Personally, I believe not, because, gentlemen, you would have to be behind each and every man. My recommendation to the legislature is that every coal dealer be licensed. Then when anyone is reported to our office for short weighing coal, instead of bringing him into court have the sealer submit all his 
facts and evidence, and if it is justifiable with one stroke of the pen we will suspend his license or revoke it.

The Charrman. At this point on the program there was to have been an address by Mr. Charles G. Johnson, of California. Unfortunately, Mr. Johnson can not be with us. Next on the program is the paper of Mr. Ralph IV. Smith, of Wisconsin.

\section{MECHANICAL VERSUS SUPERVISIONAI WEIGHTS AND MEASURES WORK, BY RALPH W. SMITH, CHIEF INSPECTOR OF WEIGHTS AND MEASURES OF WISCONSIN.}

In talking upon the subject of a comparison between the mechanical and the supervisional sides of weights and measures work. I do not hope to present any distinctly new thoughts. I lay no claim to a greater knowledge of the details or a more comprehensive grasp of the possibilities of weights and measures work than is possessed by any of you. But I have two hobbies, so to speak, in connection with my rork; one of these is the metric system, which I sincerely hope to see generally adopted in this country at no far distant date; the other is a sort of homemade ideal of what weights and measures supervision should mean, an ideal which I strive to keep before me in my own work. I do not wish to pose as a teacher but rather as a reminder; and if the thoughts which I present are obvious I think at the same time they are frequently overlooked and forgotten, and if my remarks are instrumental in bringing them again to your attention I shall feel that niy paper has served its purpose.

You will agree witl me, I think, that weights and measures work may be rather sharply divided into two general classes, one of which deals with the equipment itself and the other with the manner in which that equipment is used; and I shall refer to these two classes as the mechanical and the supervisional.

In the early days of weights and measures activity, thought was largely given to only one phase of weights and measures work, namely, the condition of the various weighing and measuring machines and devices which were in use. This was proper, because the first essential requirement for desirable conditions along this line is that the weighing and measuring instrumentalities themselves be correct. So, for the first few year's attention was concentrated upon eliminating faulty devices, testing and adjusting and approving such devices as it was proper to use, and working with the manufacturers in raising the standard of new equipment.

The importance of this work can not be overestimated. As I said before, it is absolutely necessary that the machines themselves be of the proper type and be in proper condition in order to secure the desired results. We still find it necessary to examine critically the equipment which is in use and new equipment which is being manufactured for use, with a view not only to maintaining the standards established, but also to improving them where our experience has shown improvement can be made. The actual testing of equipment is a feature of our work which can never be done away with, because a scale or an oil pump is nothing but a machine and as such will wear out and will get out of adjustment. The ordinary merchant or user of such equipment is not sufficiently skilled to recognize the necessity for, or to make, the necessary repairs and adjustments, and as a result this work falls to the weights and measures official. 
I shall not presume to advance any suggestions as to the methods of performing the mechanical work except to point out that it is by his expertness along mechanical lines that the inspector in the field is first judged. He should constantly strive to perfect himself in the retails of his work, keeping the motto of "Accuracy" ever before him.

And if I may digress for a moment, I would like to emphasize the necessity for care on the part of the official in properly marking the equipment which he examines. This is of prime importance, first, because it is an assurance to the merchant and to the public that the equipment has been properly examined, and, second, because it is a constant reminder of the existence of a supervising agency. This point has been brought out by Mr. Holbrook in his recent book of information to weights and measures officials in which he says:

When apparatus is sealed, it is desirable that one be able to ascertain from the apparatus itself certain facts; for instance, by what authority it was sealed and when it was last sealed.

The mark placed upon equipment by any sealer should be as conspicuous as possible, and it should convey to all interested parties not only the fact that the equipment has been examined, but also the date on which it was examined. 'The practice of leaving the last year's seal upon equipment without change when it is found upon subsequent inspection to be correct should, I believe, be condemned, because after the sealer has left there is nothing to show for his most recent inspection except the report which is left with the merchant. The report is a necessary document, but the seal upon the actual equipment itself is the thing which the public sees and this seal should convey all possible information.

The effects of the attention given to the mechanical side of our work have been most noticeable during the first few years of a department's existence. The result of this activity has been that the faulty and fraudulent equipment has been gradually eliminated and that the error's found on the later inspections have been largely due to what I may term "natural causes"-wear, the accumulation of dirt, carelessness, etc.; and as the mechanical condition has improved it has become the duty of the sealer to devote a greater portion of his time to the supervisional side of his work.

I have said that it was his duty to devote more time to the supervisional work, and I used that term advisedly. I think most of the laws under which we operate make it mandatory for the sealer to perform try-out work of some kind or other, aud, while supervisional work embraces other activities besides try-ont work, the implication is that the sealer should perform this work just as faithfully as though it were specified in the statutes. The conscientious sealer overlooks no opportunity to benefit the users of weighing and measuring equipment and the public in general, and for his department to lealize its greatest usefulness he must branch out into many fields not specifically defined in his law.

Briefly, supervisional work embraces try outs made upon packages put up for sale and upon packages in the process of delivery, inspections of weighing and measuring equipment (and I contrast this with actual testing of such equipment), educational work among merchants and users of scales and measures, educational work among the 
people at large, and, finally, prosecutions. At the present time I consider this phase of the work to be fully as important as the mechanical part, and I feel that it should receive an equal, if not a greater, amount of attention from the weights and measures official.

We have never before experienced a period in which high prices have so uniformly prevailed or, in consequence, a period in which slight deviations from the straight and narrow patl of absolute accuracy have meant so much to the purchaser. The veights and measures official, whether he be the director of a State departinent or the inspector in the field, may well feel a justifiable pride and satisfaction in correcting even the smallest irregularities in the equitable determination of quantity.

By try-out work, as I shall use the term, I mean the neighing up of packages put up for sale by the merchant himself, whether on his counters or in process of delivery, and also packages put up by various manufacturers and found upon the inerchants' shelves. No purpose is served if a merchant's scales are correct providing he does not use them correctly. If packages are put up which are short in weight it may be due to one of sereral causes: The scale may be out of balance, the merchant may be careless, his clerks may be improperly instructed, he may not be familiar with the provisions of the net-weight law, or he may be willfully dishonest. Fortunately, the last reason will not often hold good.

Once telling a merchant may be all that is necessary in a good many cases, but I believe it will, in the majority of instances, be necessary for the sealer to exercise a rather careful supervision extending over a considerable period before compliance with all of our regulations becomes automatic on the part of our dealers. Visits of inspection at frequent intervals, particularly when the visits are innexpected, have a very salutary influence upon the mcechant. If he is careless, it will help him to overcome his carelessness; if his clerks are not properly instructed, that instruction can be giren and emphasized by the sealer; and, if the merchant is willoully dis lonest, he will be deteried from indulging in fraudulent practices by the fear of being caught by the sealer, and erentually compliance will become a fixed habit.

Try-ont rork also includes investigations in other places than a retail store. It is the sealer's duty to see that coal companies and grain companies, wholesale establishments of different kinds, milk depots, bottling plants, etc., comply with the regulations applicable to those businesses. And one of the important things, it seems to me, in try-ont work is to approximate as closely as possible actual "customer conditions." This may best be realized when examining goods put up for delivery or in process of delivery.

The investigations of complaints preferred by various consumer's also fall under this lieading, and I might say that I believe one of the best ways for the weights and measures official to advance his department and make it valuable is to encourage his people in reporting all apparent violations of the law for investigation. If a person reports such a violation or reports what he thinks to be a violation and finds that the sealer promptly and thoroughly investigates the matter and takes rigorous action to correct the error, if error is found, he immediately conceives a very farorable impression of the 
department and of the official and feels that his interests are being properly safeguarded. This is equally true whether the complainant be a householder buying from a retail merchant, a retailer buying from a wholesaler, or a wholesaler buying from a manufacturer. In any event he is made not only a friend of the department, but in most cases will become an ardent supporter of it and from that time on will lend that cooperation which is so essential in achiering results.

When a place of business is visited for the purpose of making try outs upon package goods or for investigating methods of sale, the equipment used by the dealer should be examined to see that it is being maintained in proper condition. It is only a matter of a moment to see whether a scale is in balance and working freely, and the vibration of a computing scale may be as readily noted. "Since balance has been mentioned, I might say that I consider a scale out of balance a fraudulent weighing machine, and I think that it should be treated as sucl. I can see no reason why a merchant using one of our modern computing scales, where the balance can be checked with no effort at all on every occasion when the scale is used, should maintain such a scale in an out-of-balance condition. This can only be accounted for by gross carelessness or by a desire to defraud, and I think that if this condition is found repeatedly it is sufficient grounds for prosecution.

Nor should examination of equipment stop with the scales. The oil pumps should be checked to see whether they are working properly; the measures used for heary oils should be examined to see that they are not partially filled or coated. thereby lessening their effective capacity; weights should be examined to see that the adjusting material shows no evidence of having been tampered with since the last sealing. In other words, the supervisional visits should be a general survey of the merchant's establishment for the purpose of determining his compliance or noncompliance with our regulations.

I also believe that the importance of keeping full and complete records of all try-out work performed should not be overlooked.

I have said that education was one of the important features of a sealer's duty. I think that is one of the fundamentals upon which our success is largely dependent. Educational work properly carried on will make friends or enemies of the people we work for and with. Let us convey to the merchant the idea that we want to cooperate with him and that we desire his cooperation with us. Let us encourage him to look upon us more as assistants than as inspector's.

And educational work should not cerse with the merchant, but should be carried to the public generally. Many means are arailable for this purpose: Helpful publications for general distribution, the public press, meetings of business men, meetings of women's clubs and various societies, frequent reports of our work, etc. There was a time in the early days when an exhibit of faulty equipment was considered an essential part of any weights and measures talk; but I think that the time has passed when we should lay emphasis upon the faulty, fradulent side of our work. We should hold up to view the good equipment, the correct scales and measures, rather than the incorrect ones. In publicity work among the housenives an effort should be made to interest the individual.in checking all 
purchases made by means of reliable sealed equipment. That publication of the Bureau of Standards entitled "Measurements for the Household "will be found a source of great assistance along the line of weights and measures from the standpoint of the laymen. It should be borne in mind that the housewife is the one who makes the majority of purchases for the household and that missionary work among the housewives will bring most satisfactory returns. Cooperation may well be termed the keynote of successful weights and measures work; and cooperation is dependent upon knowledge. The dissemination of knowledge concerning all that relates to our departments-laws, regulations, and our own activities-should be our constant aim. Consistent, constructive publicity will ácomplish wonders.

As the final phase of supervisional work comes prosecution-the means by which the weights and measures official enforces compliance with the law and regulations. And as prosecution is a heavy weapon, it should be used judiciously. It should be resorted to only when gentler methods fail or when the gravity of the offense makes necessary a severe punishment.

If I may sum up what I have tried to express, I would say that I feel we must consider our duties as weights and measures officials to be twofold-mechanical and supervisional-and that for our work to attain a full and complete development each phase must receive its due share of attention, with particular emphasis at this time upon the supervisional. And.I would like to leave with you the two words which I feel convey the essence of my thought about our work"accuracy" for the mechanical side and "cooperation," with its corollaries "knowledge" and "publicity," for the supervisional side.

\section{THE SALE OF WOOD, BY H. A. WEBSTER, COMMISSIONER OF WEIGHTS AND MEASURES OF NEW HAIMPSHIRE.}

Mr. Chairman and gentlemen, when I accepted Mr. Fischer's invitation to address the conference on the matter of regulating the sale of wood for fuel purposes I stated that I did not regard myself as an expert in this matter, nor did I consicler the bill which was passed at the recent session of the New Hampshire Legislature as an absolutely perfect one. Until recently there existed in New Hampshire a custom of selling wood for fuel purposes by an indefinite load measurement, and, of course, the only avenue through which to proceed with any success in alleviating the condition of affairs was the legislature. I therefore submitted a bill as an amendment to the original weights and measures law which establishes definite measurements by which wood for fuel purposes shall be sold.

The old statutes concerning the sale of wood were not as stringent as they should have been, and consequently many people when purchasing wood by the "load" rather than by the "cord" or by a "standard load measure" had been paying at the rate of $\$ 24$, or more, a cord for wood. Such a condition of affairs was deplorable, for the public had had no redress, and therefore had been at the mercy of many unscrupulous wood dealers. The term "load" used in the sale of wond was vague, for it represented no system of measurement, and therefore provided a very convenient opportunity for deception. 
Wood dealers in New Hampshire were thoroughly familiar with the insufficiency of the old law, and the public was also familiar with it and constantly appealed to me for help, for they realized that carelessness and indifference in the estimation of quantities in the sale of wood ought to be prevented. 'The prices demanded by the wood dealers were fully ample, and therefore they had not the least excuse for delivering, for instance, two-thirds of a cord as a "load" and accepting the price of a cord, for they deliberately took one-third of the purchase price.

I gave the matter a great deal of publicity in the newspapers which aroused the people of New Hampshire to a realization of the prevaling conditions. I pointed out to them that they should see to it that their chosen representatives in the legislature voted for the bill that had been presented, and thereby abolish the iniquitous custom which had been very flagrant throughout the State and which was nothing more or less than a gross imposition upon the public.

After the wood dealers became aware that there was a movement on foot to establish some definite measurements by which wood for fuel purposes should be sold, they literally swarmed into my office. In most instances the dealers agreed with me that something should be done to relieve the situation, but were very solicitous in offering suggestions, which, if accepted, would of course in the main have been helpful to them. It was the opinion of several wood dealers that the law should define the number of cubic feet in a cord of loose wood. I told them repeatedly that a provision of this sort would not be considered.

In substance, the New Hampshire wood law provides that all wood sold for fuel purposes over 16 inches in length shall be sold by the cord or fraction thereof, and that no cord of any length wood shall contain less than the equivalent of 128 cubic feet of compactly piled wood. It provides that wood 16 inches in length and under, edgings, bobbin wood, clippings, slabs, and other waste may be sold by the cord, or by the load in the loose, provided the load contains 80 cubic feet; that three-fourths of a load contains 60 cubic feet; that one-half of a load contains 40 cubic feet; that one-fourth of a load contains 20 cubic feet; and that no wood shall be sold by the load in any other dimensions than as heretofore stated. It provides that wood not exceeding 12 inches in length and waste may be sold by the bushel and also that no person, firm, or corporation selling or offering for sale wood not exceeding 16 inches in length, edgings, bobbin wood, clippings, slabs, and other waste by the load in the loose shall neglect after May 1, 1919, to specify in figures at least 1 inch in height the cubic contents of the cart or delivery vehicle upon the outside of the container used in such delivery. The penalty for violating this section of the weights and measures law is provided for in section 7 of the original act, which states that upon the first conviction a fine shall be imposed of not less than $\$ 20$ nor more than $\$ 200$ and imprisonment and that a fine of not less than $\$ 50$ nor more than $\$ 500$ and imprisonment shall be imposed upon a second conviction.

After making a careful review of the laws governing the sale of wood for fuel purposes in other States, I was surprised to find that so little legislation had been enacted on this very important matter. 
North Carolina and Vermont are the only States, in addition to New Hampshire, which have adequate regulations concerning the sale of wood. The North Carolina regulation is statutory and is as follows:

All firewood sold in incorporated towns shall be sold by the cord and not otherwise; and each cord shall contain 8 feet in length, 4 feet in height, and 4 feet in breadth; and shall be corded by the seller under the penalty of $\$ 2$ for each offense to the use of the informer.

In Vermont the commissioner has the power to regulate the sale of all commodities, and in view of this privilege which is granted in that State, Commissioner Scott issued the following regulation:

All wood sold for fuel purposes in the State of Vermont, with the exception of slabs, edgings, kindling, clippings, and other mill waste, shall be sold by the cord or fraction thereof. A cord shall contain 128 cubic feet of wood. A cord of 16-inch wood shall contain the equivalent of three piles of wood 4 feet high, 8 feet long, and 16 inches wide. A cord of 12-inch wood shall contain the equivalent of four piles of wood, 4 feet high, 8 feet long, and 12 inches. wide, and no cord of any length wood shall contain less than 128 cubic feet of wood.

In all other States where this subject is touched upon at all, with the exception of Minnesota, a cord is defined as containing 128 cubic feet, and, in fact, there is no other definition for a cord in this country. Of course, this applies to fitted wood as well as the usual cord length of 4-foot wood. There should not be several definitions for a cord of wood any more than there should be several definitions for an avoirdupois pound, and if a custom were inaugurated which would be the means of deviating from this universal measurement it would result in confusion. The people have been burdened enough lately with definitions and regulations, and, as it is probably harder to regulate the sale of firewood than any other commodity, the old system of measuring wood by the cord should be continued; but in order to prevent increasing the price of fitted wood I have found that it was feasible to standardize a load of thrown-in wood. The fact that there is a shrinkage should not be overlooked, for if a cord of 4-foot wood is sawed three times and piled again it will be found that a shrinkage exists for the reason that short pieces of wood will lie more compactly together than long ones. However, if a cord of 4-foot wood be sawed and split it will be found, after piling, that in many cases the cubic contents will be larger than in the first place. Many experiments have been made to determine tlie cubic contents of a cord when cut into various lengths and thrown hit or miss into a bin or wagon body, and it lias been found that there is a variation. Therefore, if this particular feature were embodied in any statute it would be found that in order to have an absolutely accurate definition it would be necessary to establish at least 25 or mole tables. For instance, the same definition for cleft wood would not apply to round wood, nor would a definition for 12-inch wood of either kind apply to 16-inch wood of either cleft or round wood, and, besides, the dimensions of the bin would have some effect upon the number of cubic feet. It was this particular feature which prompted me to establish a standard load rather than cord definitions for the varjous lengths of cleft and round wood. Eighty cubic feet of loose wood is approximately the equivalent of half a cord of the same wood when piled up. I realize that the ideal way of selling all woor for fuel purposes is 
by the cord measurement of 128 cubic feet, but the labor in piling will in all cases increase the price, and, of course, the main advantage in standardizing a load is that the public will be able to purchase wood by some definite measurement without paying the extra cost of piling.

Both features of selling by the cord and by the standard load are embodied in the New Hampshire law. As I stated at the beginning of this address, I do not regard the New Hampshire law as absolutely perfect, and I am of the opinion that an amendment should be added regulating the sale of edgings, as the sale of this particular kind of wood by the bundle is not prohibited, and yet if edgings are sold by the bundle the bundles should have some uniformity. However, New Hampshire has many acres of woodland, and consequently many sawmills are operated and prices charged for waste wood are low, except in the cities, and even there the people find that it is much more economical to buy either a cord, or a standard load, of fitted wood rather than waste.

The wood law in New Hampshire has been in effect only since May 1, 1919; but already the people are heartily commending it, and I thoroughly believe it is one of the most important, as well as most popular, features of the work in connection with the New Hampshire department of weights and measures.

Since I have come to this conference I have learned that Minnesota has a law regulating the sale of wood. I understand that Minnesota has defined the number of cubic feet in a loose cord of wood, etc., and I imagine that they have a great many definitions there.

The New Hampshire law does not state that 80 cubic feet of loosely piled, sawed-and-split wood is a half cord, but after making many careful inspections it has been determined that it is approximately this amount. I thought it better, howerer, not to attempt to define the number of cubic feet in a loose cord of wood.

\section{PROGRESS OF TRACK-SCALE INVESTIGATION, BY E. D. GORDON, BUREAU OF STANDARDS.}

At the time of the last Annual Conference on Weights and Measures-namely in the spring of 1916-the Bureau of Standards trackscale-testing equipments had made about 600 tests. Test car No. 1 had been in service about two years and test car No. 2 only a few months. Nearly all of this work was more or less scattered throughout the country, and logically so, for it was the purpose of the Bureau in the early days of the track-scale investigation to obtain a knowledge of railroad track-scale conditions in general as quickly as possible. This work corered all of the territory east of the Mississippi River and a few States bordering on the west bank of that river.

Since that time these two equipments have been working continuously, and, in addition to these, testing equipment No. 3 started work about one year ago. At the present time the Bureau has tested in all about 2,300 different railroad track scales throughout the country. From 50 to 100 of these scales have been tested two or three times, so that the total number of tests to date is very nearly 2,500. This work, of course, covers the entire country from coast to coast, and, although. still more or less scattered, yet it is fairly representative of the different sections of the country when based upon the density 
of scales, so to speak. As yet the Bureau has never attempted to test all of the scales of any one railroad, especially the larger systems, but in some cases it has been advisable to concentrate the work in a certain locality.

Although this number of 2,500 seems somewhat large at first, yet I believe it would be interesting to plot the results of your answers if I were to ask each of you gentlemen to give an estimate of the total number of railroad track scales in the United States. I am inclined to believe that some of your replies would be similar to that of a State superintendent of weights and measures one time when a Bureau testing equipment was about to do some work in his State. He met us one day at the beginning of the work and during the course of conversation about our plans in his State said that he hoped we would remain long enough to test most of his track scales, although he understood that it would require considerable time, for there were at least 80 scales in the State. We concurred in his opinion and stated that we would probably test the majority of them in that case. As a matter of fact, there were more than 600 track scales in that State, and at that particular time we tested about 90 of them.

The Bureau has recently made a census of railroad track scales throughout the country, including those owned both by railroads and by industries. The results of this census indicate that there is a total of approximately 10,000 railroad track scales in the United States. From these figures, then, you can readily see that to date the Bureau has tested about 25 per cent of all these scales. When it is considered that these tests cover a period of about five years and have been so placed that practically all of the railroads, especially the larger ones, are included in these tests, then I am sure you will agree with me that the results of the work of this investigation indicate quite accurately the general condition of scales throughout tha country. Some of you may take issue with that statement for the reason that 25 per cent does not seem to be a sufficiently large percentage in order to give an accurate representation of general conditions. However, we believe it is, because the Bureau's experience has been that when a considerable amount of work has been done on any one railroad we have found that the testing of 10 to 20 per cent of the scales owned by that road when selected at random would give a very good representative idea of the scale conditions for that particular road.

In addition to the regular testing of railroad track scales, the Bureau's precision equipments No. 1 and No. 2, have, during the past three years tested all of the railroad master scales in the country once a year, making these tests upon a regular schedule, in cooperation with the American Railway Association. In the fall of 1915, when the subject of track-scale investigation was under discussion, it was realized how important a step it would be for the proper maintenance of track-scale accuracy to have all of the railroad master scales regularly calibrated and adjusted to within a specified accuracy by a single standard. As the Bureau of Standards was the logical place to look for such a standard weight, and as the Bureau's precision equipments, because of their unique design, were the only testing outfits in the country which were properly equipped for such testing, an agreement was entered into with the American Railway Association

$155530-20-5$ 
whereby all of the railroad master scales would be tested and adjusted by the Bureau precision equipments once a year.

The far-reaching importance of this work can not be orerestimated. If all the railroad track scales were properly maintained by their respective owners, then every railroad weight throughout the country would be very closely related to a standard weight, for there is only one element of transfer between the master scale when certified as

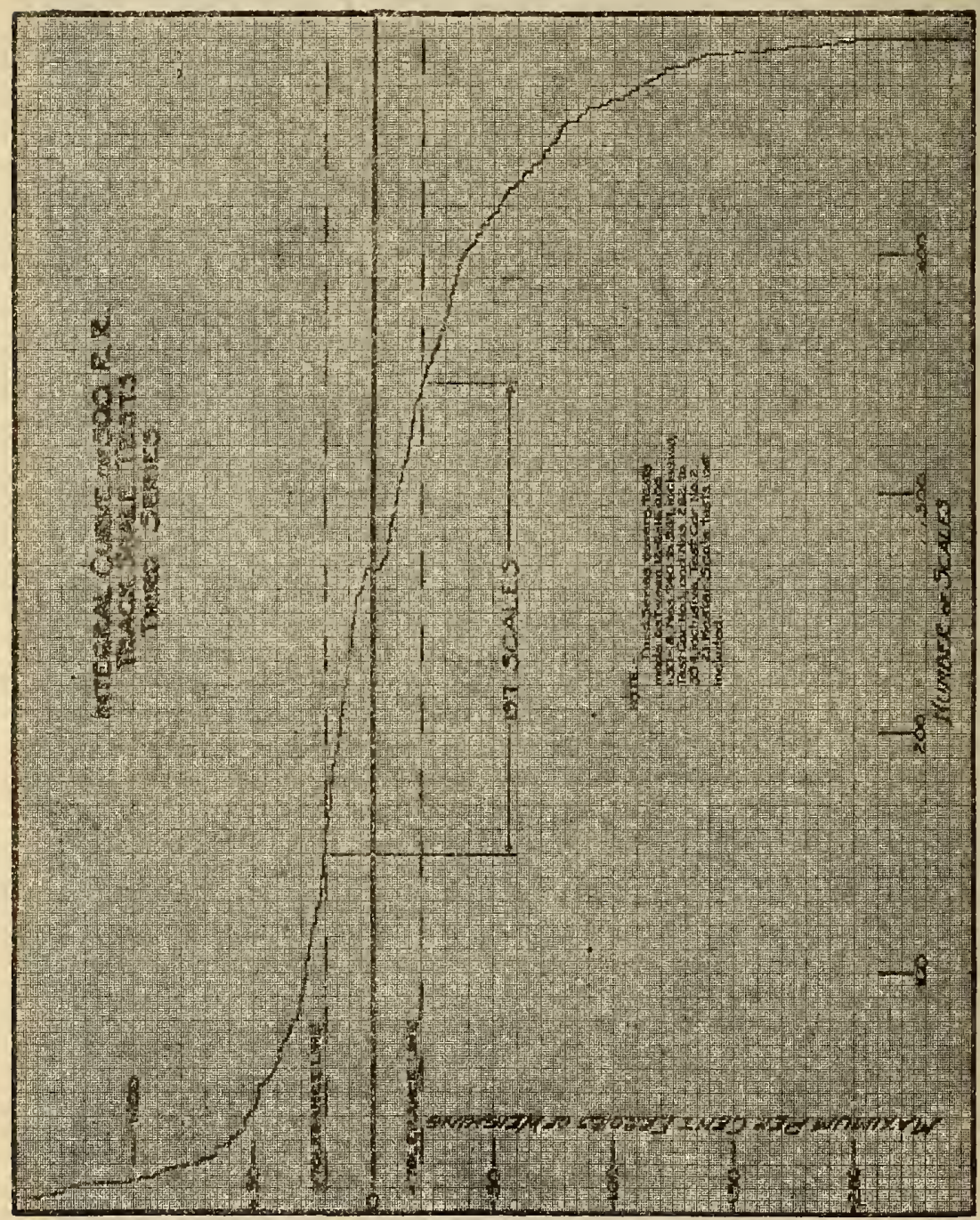

correct by the Bureau and the railroad track scale-namely, the railroad scale-test car.

Now, I wish to give in a general way a summary of the results of the first 2,000 tests made by the Bureau's testing equipments. In order to make this summary as simple and as clear as possible, I have it here in two different forms: First, in the form of graphical curves, and, second, in the form of a table (fig. 4). 
TWELFTH ANNUAL CONFERENCE ON WEIGHTS AND MEASURES. 67

The curves are self-explanatory when one is close enough to read them, but under the present circumstances I will give a few details about them before discussing the results. You will note that there are three curves here, two of then each representing a series of 500 tests, and the last one, or curve No. 3, represents a summary of the

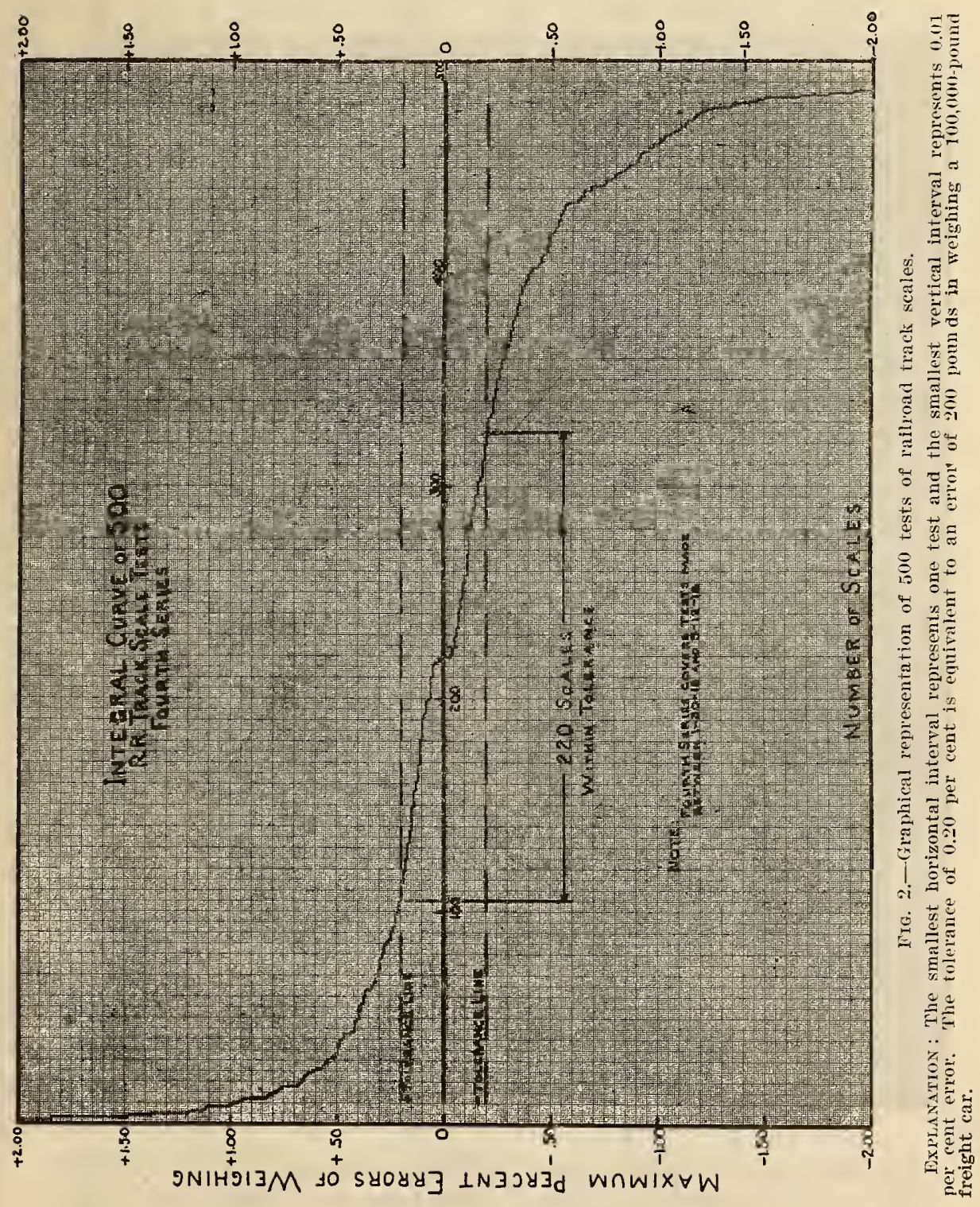

first 2,000 tests made by the Bureau. Now, upon examining one of these sheets closely you will note that it is subdivided into little squares and that there are exactly 500 such squares across the sheet in a horizontal direction, so that we have made each little square represent one scale test. In the vertical direction each little square, 
of which there are 400 , represents 0.01 of 1 per cent error. In plotting the curve, therefore, we plot the number of scales in the horirontal direction and the errors in the vertical direction. The heavy black line in the center of the sheet represents zero error and is the dividing line between the plus and minus errors. You will note that

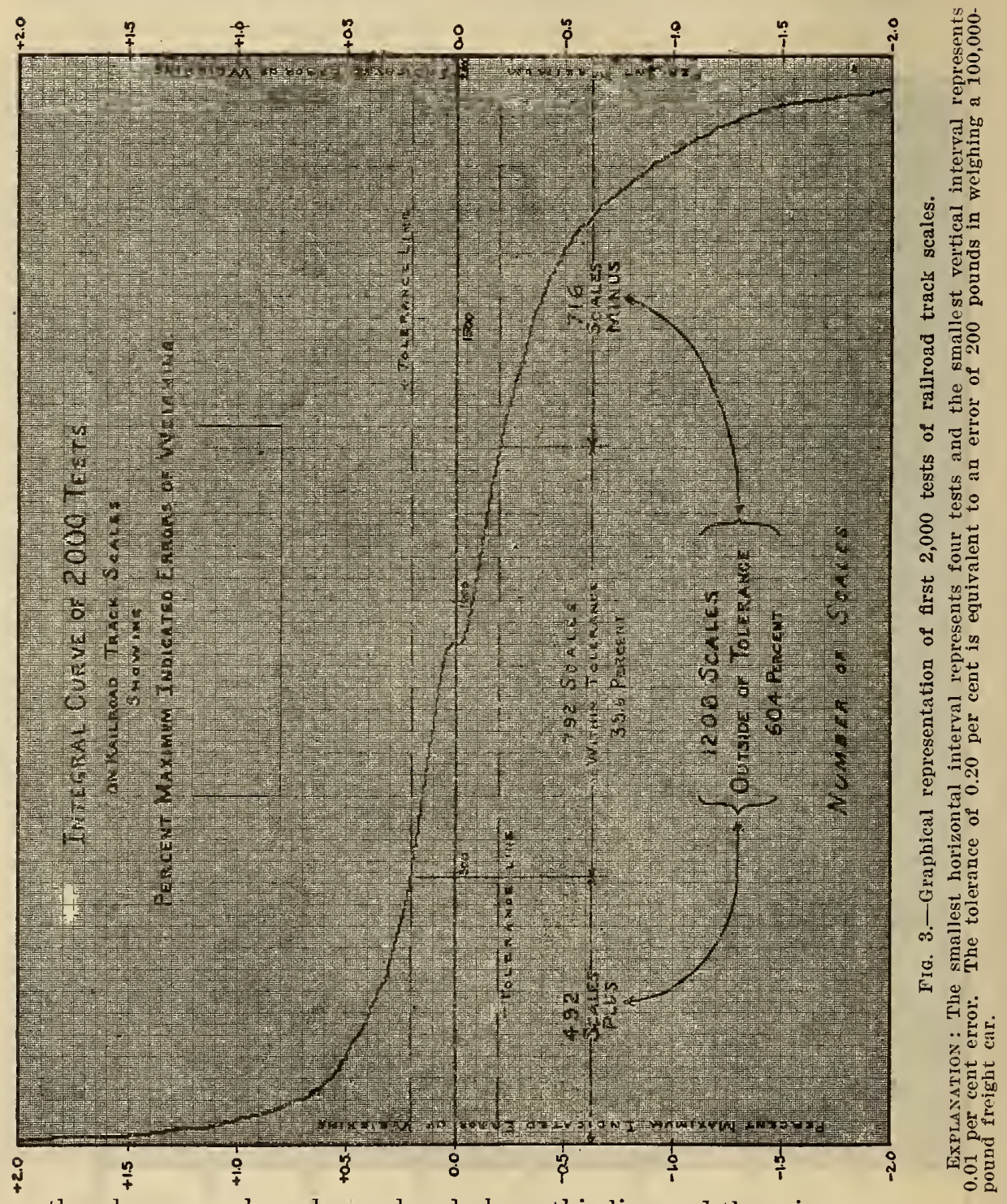

the plus exrors have been placed above this line and the minus errors below. The manner in which we plot these curves may be of interest. The first thing that is done is to draw the zero line and then indicate on the first vertical line to the left the points for the percentages of error. You will note in this particular curve that the top line represents +2 per cent and the bottom line -2 per cent. 
Then we proceed with the results of the 500 tests by separating all the plus errors from the minus errors and then further separate these errors into groups, depending upon their value. Now we are ready to plot the results, and upon curve No. 2 you will note that in this particular case we had three tests with errors greater than +2 per cent. The next largest error was +1.85 . There was only one scale that had this particular error. The next largest error was +1.49 , and there was but one scale having this error. This method is continued until all the plus errors have been plotted. Then the minus errors are plotted in the same manner. You will note that toward the ends of the curves the horizontal lines are short, which indicates that there are in these cases only a few scales tested with these errors, and in the middle of the curve the horizontal lines are relatively longer, which indicates that there are several scales having these particular errors in each case. After the curves have been plotted then the tolerance lines are drawn and are shown on the curve as the horizontal dash lines above and below the zero line. This tolerance represents plus or minus 0.2 of 1 per cent.

You will note that the most striking feature about these curves is their similarity. This is somewhat to be expected, because the Bureau in all this work has endearored to make these tests as representative as possible of the general conditions, and for this reason very few duplicate tests have been made, and also in each year's work the Bureau has endeavored to cover the entire country as far as possible. Tou will note also that the number of scales having a minus error was slightly greater than the number of plus errors. This condition would tend to prove the idea that all scales theoretically will wear toward the minus error. However, in this connection I wish to state that in all the Bureau's experience in carrying on this investigation we have never discovered any attempt at fraud. In this last curve (fig. 3) there is included all the tests contained in the other curves. In this case, each little square horizontally represents four scale tests. The squares in the vertical direction represent hundredths of 1 per cent error, the same as on the other curves.

The table given herewith was hastily prepared for summarizing the same 2,000 tests in a comparatire form, so that at a glance one is able to note several interesting features connected with each series of the 500 tests.

Before proceeding any further let me state that these 2,000 tests include both railroad-owned scales and industry-owned scales, in a proportion of approximately 1,100 to 900 , respectively.

Summary of 2,000 tests on railroad track scales.

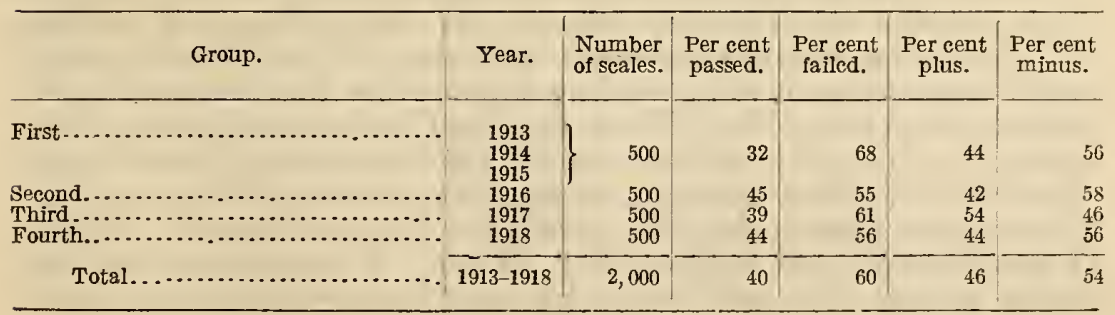

FigURE 4. 
Now, suppose we turn our attention for a few minutes to the tabulated form (fig. 4). Each vertical column is headed by appropriate notation; the first column gives the grouping or series of test; the second column gives the year during which the tests were made; the third column gives the number of scales in question; and so on across the sheet we have the per cent of scales which passed, next the per cent of scales which failed, and the next two columns give the per cent of scales having plus errors and minus errors.

In the horizontal lines are given statistics for the first, second, third, and fourth series of 500 tests, and then the sum or total of 2,000 tests.

This table is a hasty analysis, we will admit, but it gives in a general way the results of the investigation as it has progressed from year to year, and it also indicates quite accurately the general conditions of railroad track scales throughout the country. You will note that the ralues in the failed column are larger in erery case than the values in the passed column. It is interesting to note how persistently the ratio of 40 per cent passed and 60 per cent failed continues. The ratio of 32 per cent passed and 68 per cent failed, as shown for the first series of 500 , is somewhat different from the others and tends to show that a general improrement of track-scale conditions took place after 1915 . This ditference, howerer, is not sufficiently great to enable us to make any decided statements.

Furthermore, it is very singular that this ratio of percentage for the railroads and industries separately happen to be the same. It would be well to state here that we have found good scales and bad scales on both sides. It is true that we hear considerable amount of criticisms pro and con about railroad scales and industry scales, and the criticisms are often justifiable in particular cases; but as a general proposition they even up, as we have seen. I well remember several years ago testing an industry scale which was used by a coal operator for selling the coal produced at his mine. We found the scale with an error of minus 4,000 pounds, or 2 tons. He was losing more than $\$ 100$ a day because of this scale's condition, yet he had deliberately purchased a cheap scale of light construction and had allowed it to wear out apparently without any attention. I asked the operator why he had an engineer to take care of the machinery in his power plant, but apparently had made no effort to take care of his scale, upon which his income to a large extent was based. He said that he did not know any better. I was glad to hear him admit the truth so frankly, and personally I believe that that reason is true for the majority of cases, especially concerning industries, and is also true in the case of railroads more generally than is admitted.

Concerning railroad scales, the Burean's testing to date includes work on about 100 different systems. Of course, this work includes all of the so-called large systems and many of the smaller roads. In this connection it is interesting to note that the Bureau has two perfect scores on its list. There are about 15 large railroad systems which own 100 scales or more each. Of these systems there is one upon which we have tested more than 30 per cent of its scales, and in every case these scales have passed the Bureau tolerance. Moral: If one railroad can do this, they all can. Furthermore, this particular system does not possess an ideal testing equipment, but it 
does, however, lay very great stress on organization. We have just one other railroad, a comparatively small one, with a perfect score of all scales tested within tolerance. This railroad has a fair testing equipment and a good scale inspector.

On the other hand, the Bureau has in this list abont 12 railroads with a perfect score in the other direction; that is, not one of their scales tested has passed the Bureau tolerance. In all of these instances the railroads are comparatively small ones, and very few of them possess any testing equipment at all. Judging from the condition of the scales tested, their inspection force also must be of very poor material. Speaking of work on the smaller systems, I wish to state that we met with an interesting experience last spring, which is somewhat typical, I believe, of the attitude assumed by many railroad officials who apparently know very little about track scales and their importance. On this particular road we tested some six scales at this time, and all of them failed to pass the Bureau's tolerance. One of the scales had an error of more than 5 per cent plus. A couple of weeks or so after we had reported on this work we received a letter from the chief engineer of this road which stated that he understood we had tester an industry sale along his line with whom they were having some disagreement about correct weights. He wished to be advised of the condition of this scale, for, he stated, that he was under the inpression the industry scale was weighing light. As a matter of fact, this industry scale had an error of minus one-half per: cent. So here we had a railroad with their own seales showing errors in their own faror disagreeing with an industry whose scale was conisiderably better than the railroad scales, and as a matter of fact, one of the railroad's scales was 10 times as much in error as the industry scale. It did not take us long to inform this engineer of the actual condition on his own road, and we also gave him the information in regard to the industry scale. It is needless to say that we heard nothing further about the matter. On this particular road we found one scale with an error of 13 per cent.

Not long ago we had another typical case which I believe is still quite prevalent; that is, the idea that carload weights can be estimated with accuracy. This point happened to come up in a disagreement between another small road, whose scales were in very Lad condition, and an industry along the right of way. In this particular case the industry was a stone quarry, and they were objecting to the railroad scale weights because they did not check up with their quarryman's estimate of the contents in the cars.

Gener'ally speaking, the larger railroad systems are in much better condition than the small ones, both in regard to testing equipment and organization of scale departments, and such a condition is naturally to be expected; but, taken as a whole, the railload-track-scale question at the present time is very far from satisfactory.

The field work which is done by the Bureau's testing equipments is followed up in several different ways: First, a detail report is made upon every test, which at the present time is sent to the Federal manager of the particular road in question; second, commun ications are issued from time to time relating to particular phases of the track-scale question, such as testing equpments, care of scales, methods of inspection, methods of test and other problems of main- 
tenance; third, the development of proper specifications. It is true that most of this effort applies primarily to the mechanical side of the general problem and not very much to the personal side; that is, organization of scale departments. This personal side, however, is a vast problem in itself and, furthermore, is a problem which can not be solved as readily as the mechanical one. The Bureau has done rery little work along this line thus far, but hopes to tackle this problem more vigorously in the early future.

As has been stated heretofore, nearly all of this work is original testing and very little duplicating work has been done. However, the investigation has progressed far enough now to make duplicating tests an important factor, and a separate file for this purpose has already been started, but as yet a sufficient number of tests have not been made to enable any general conclusion to be drawn at this time. In another year we will probably be in a position to report on this subject.

Work of this character will also have an important bearing on the tolerance problem, for we feel very certain that the results of this kind of work will give a much larger percentage of scales passing tolerance, because there has been a decided change in attitude toward the subject of proper maintenance of railroad-track scales in the last two years. This new interest is especially marked in regard to specifications, and to-molrow afternoon, I believe, Mr. Briggs will tell you about the recent developments along this line. It is undoubtedly true that this investigation, which has been carried on during the past five years by this Bureau, has been largely responsible for this change in spirit toward this very important subject.

Mr. SCHWARTz. I make a motion at this time that the next paper, by Mr. Harrison, be held over until to-morrow afternoon, and that we now adjourn. Dr. Stratton leaves to-day, and that gives only one talk for to-morrow afternoon.

The Secretary. A motion is made and seconded that we postpone the next paper and adjourn at this time. What is your pleasure?

(The motion was agreed to.)

(Thereupon, at 5 o'clock p. m., the conference adjourned to meet at 10 o'clock a. m., Thursday, May 22, 1919.) 


\section{THIRD SESSION (MORNING OF THURSDAY, MAY 22, 1919).}

The conference reassembled at 10 o'clock a. m. at the Bureau of Standards, Mr. L. A. Fischer, secretary, presiding as chairman.

The Acting Chairman. The meeting will please come to order. I will not call on Mr. Harrison at this time. His paper was postponed from yesterday afternoon and will come up later, inasmuch as he is occupied just now with some other duties.

\section{AUTOMATIC SCALES, BY H. O. HEM.}

Members of the conference on weights and measures, I am glad the subject of automatic scales has been assigned to me. I am deeply interested and a believer in automatic scales. I shall try to avoid a technical paper, which would interest only those designing scales.

The sealers present are familiar with the standard types of automatic scales, especially the counter scales, as they come in contact with them more than the other types.

Automatic weighing is now a live subject. Twenty years ago no retail store wanted an automatic scale, but now that type is in very great demand. In all up-to-date retail stores beam counter scales are now almost a curiosity, while in the places where the larger types are used, such as railroad-track and wagon scales, the beam scale predominates. Automatic scales are preferable to beam scales, and always have been, but dependable automatic scales have been more difficult to construct. Now, however, manufacturers are learning more and mole how to make this type of scale, and shortly we will see automatic scales in use for all purposes, because weighing can be done much more quickly and more accurately, since the operator does not have to move poises or wait for the beam to balance in the center of the trig loop.

I will not attempt to give you a technical description of scales in common use, with which you are familiar, but will confine my remarks to a few scales that may be called "specials." The war was responsible for a large number of different types of automatic scales, which were then special,'but which have now come into general use.

Take, for example, scales in powder mills. When we entered the war, labor was scarce and the output had to be increased considerably; hence more new help was needed, more speed in production was necessary, and the amount of danger increased proportionally. Powder mills are usually built in a part of the country where ground is cheap and fit for little else and where people do not live close to the plant. Buildings where explosives are made are usually small, generally constructed of wood instead of structural steel. In case of explosion, structural steel seems to be able to sail through the air for a considerable distance, while wood breaks up into small splinters. In most cases the buildings are surrounded by embankments extending as high as the buildings so as to confine the explosions, should they occur, to that particular location. The men working in the 
plant must not even have nails in their shoes. Every precaution is taken to reduce the danger of explosions.

I have been in a number of powder mills, have studied their weighing problems, and designed scales to increase the output of the mill, as well as to reduce the danger of explosions; for instance, take nitroglycerin, usually kept in a large tank the bottom of which is about 3 feet above the floor. To make up various batches of dynamite it is necessary to weigh out definite amounts of nitroglycerin. For this purpose I found in use the ordinary dormant beam scale with cast-iron platform, cast-iron corner plates or frames, as well as pivots, links, and loops under the platform. The glycerin is transported and weighed in a wooden barrel set in a frame mounted on an axle with wheels having pneumatic tires, usually called the "glycerin buggy." This buggy is rum on the scale platform and counterbalanced on the ta re beam. A rubber hose is connected close to the bottom of the tank, and the other end of this hose is then placed over the top of the barrel, so as to allow a certain amount of the glycerin to run into the barrel on the buggy. An automatic scale instantly indicates when the right amount of glycerin is in the buggy, and the men in attendance can tell from the position of the indicating hand when they have nearly the desired amount of glycerin, enabling them to pinch off the supply slowly. They then lift the hose out of the barrel and wipe off the end to prevent any nitroglycerin from dropping onto the scale or floor.

It happens at times, that in taking the hose out of the buggy a ronsiderable amount of nitroglycerin spills on the scale, runs under the scale platform, and splashes in the loops and bearings. This makes the danger of explosion very great, because the platform really has to be taken up and the whole scale washed out, as well as the floor. The floors and all parts are usually covered with sheet lead to prevent the nitroglycerin from soaking into the wood. The danger lies in lifting the platform of the scale, for if any nitroglycerin has splashed into the bearings the swinging of the platform would be liable to set it off, and there would be no evidence left to indicate the cause of the explosion.

After consideration of these weighing problems I designed special suspension scales with overhead levers, also a wooden platform hung directly under the levers, so arranged that in case of breakage the parts could not drop down to the floor. The poises on the beans have fiber stops, and the platform posts and suspension rods are covered with sheet lead.

We also designed and built automatic scales for the dope houses, where the various ingredients for dynamite are mixed. These are used similar to furnace-charging scales. Six or seven ingredients may be weighed up in a hopper suspended from an overhead scale. The operator always loads the ingredients in the same rotation. He has a card of the mixture made 11 which shows the total weight as each ingredient is added, and with the automatic scale he can see the indicator and is able to tell just when he has the right amount of each ingredient at a single glance, while with the beam scale it is necessary to set the poise on the beam and then take out or put in material until the beam balances. So. automatic scales materially speeded up the output when the Government needed it most. 
We also built automatic scales for determining the density of powder. A certain-sized cartridge is supposed to contain a certain definite weight of powder. These scales have a zone chart which indicates whether the various sizes weigh too much or not enough powder to each stick.

For packing dynamite and powder automatic scales are used for taring the boxes to a predetermined weight. Other automatic scales are used in roller conveyers with a section of the conveyer mounted upon the scale platform. The boxes, tared to a uniform weight, may be loaded with a definite weight of powder or dynamite.

These are only a few of the special scales made for powder mills which are now standard equipment. We also made special automatic scales for loading stations for weighing the powder charges of shells so that the range could be predetermined with accuracy. Automatic scales were not only used for weighing the charges, but for weighing the shells at the various stages of manufacture. Scales were designed for weighing the copper bands, the time fuses, as well as scales for weighing the finished shells, scales with special charts showing the standard weights for the various sized shells and the allowable tolerance for each shell. It is practicably impossible in manufacturing large shells to have them come to a certain predetermined weight, but by having a certain tolerance and knowing just how much lighter or heavier the shell is than it should be the operator, when weighing the shell, would see a mark on the chart in line with the inclicating hand and would stamp the same mark on the shell. Thus, when a shell is handled in the field, the men know just exactly the amount of powder to use in connection with a shell having such mark.

For airplanes a great number of special automatic scales were furnished, such as scales for testing airplane motors, scales for weighing propellers, scales for determining the amount of power required to revolve propellers at various speeds, as well as scales for determining the end thrust or the end pressure at the various speeds.

We are also making dynamometer scales with horsepower charts graduated so as to read the horsepower directly, as well as the torque in pounds.

In the development of the Liberty motor we were called upon to furnish several special automatic scales for determining the amount of gasoline required per horsepower per hour; for determining the amount of lubricating oil required; for testing the tension of the piston rings and of the valve springs; for weighing the pistons and the connecting lods; for deternining the center of gravity of such connecting rods, and so to reduce vibration; and for a number of other purposes.

The Government wanted to know the power of a Liberty motor at high altitude, so they mounted a Liberty motor on a truck with all testing paraphermalia and sent it up on top of Pikes Peak. Even this equipment was provided with an automatic scale to determine the horsepower.

In connection witl the manufacture of motor trucks, we have made many special automatic scales. Also we have developed special scales for use in the manufacture of rubber tires, very accurate scales with predetermined weight charts, for weighing the amount of rubber required in truck tires. Such scales have platforms 12 feet long 
and 1 foot wide, of 150 kilograms capacity, with a chart graduated to 50 grams. The height of the platform is about the same as the die in the machine from which the rubber is molded. The rubber is here cut off about the length required to go around the tire and must be of a certain weight to aroid wastage, as the rubber when cured is worth only a small amount, while in the condition when it is weighed it is worth 75 or 80 cents a pound. We built automatic scales for weighing the iron cores on which the tires are vulcanized; scales for reighing the rubber before it is put on the tire; scales for weighing the tire after it is completed. Similar scales for weighing the rubber used in pneumatic tires have been developed. In this type the rubber for the tread is gauged for thickness, cut to lengths, and then weigherl and trimmed to a tolerance of about 1 ounce.

These are only a fow of the special scales which we made in our efforts to help win the war, automatic scales ranging in capacities fiom about 1 pound to 60,000 pounds.

I would like to show you a few slides of these special scales. The construction is musual, and $I$ think it may be interesting to you to see them.

(The speaker then exhibited a number of lantern slides and explained the method of operation of the various scales shown.)

The Acting Champras. The interesting talk by Mr. Hem illustrates the special devices designed to meet war conditions. Are there any questions that any one would like to ask Mr. Hem? We will he glad to hear them.

\section{APPOINTMENT OF COMMITTEES AND DISCUSSION OF PROGRAM.}

The Acring Chairucar. I rould like to interrupt the program at this time to bring up one or two matters that should be attended to. First, I think we ought to arrange for the appointment of the usual committee on nominations, in order that people who have views as to whom candidates should be can consult with them from time to time. The more time these gentlemen have to consider that, the better it will be. The chairman will be glad to entertain a motion for the appointment of such a committee.

Mr. BARNARD. I move you that the chairman appoint a committee of three on nominations and a committee of five on resolutions.

Mr. Irvine. I second the motion.

(The motion was agreed to.)

The Acting Chairman. The suggestion has been made that our program be so accelerated. or changed, as to close up matters tomollow afternoon. To find how general the sentiment is I should like to have a rote on it.

Mr. Tucker. Mr. Chairman, I hope that due consideration will be given to the fact that gasoline pumps are scheduled for to-morrow afternoon. I understand that some representatives of the pump companies are not in town at the present time, but they made provision to be here at the discussion that will take place at the time appointed in the program. I think they ought to get consideration. and that we should not have that discussion at some time when those who are prepared to be here at a definite time are out of the city.

The Acting Chairman. Is there any further discussion? The proposition is to close up our program to-morrow afternoon and 
permit the delegates to leave the city, or do as they desire, on Saturday. Of course, they can do as they desire now.

Mr. Schoenthal. I move that the convention close Friday evening instead of Saturday as fixed by the program.

(The motion was seconded and agreed to.)

Mr. Tucrer. Mr. Chairman, we might have a Friday night session.

Mr. Barnard. Mr. Chairman, I think one of the principal discussions at this convention will be upon gasoline pumps, and I anticipate that will take all of one day, if we all express our opinions freely. I believe if we are to go away from this convention with a uniform thought on gasoline pumps it will take some time to work out our ideas, and I do not think we ought to hurry this convention to satisfy some one who wishes to go away on Saturday. I came quite a long way down here principally because of this gasoline-pump proposition, and I think we ought to give it the fullest discussion.

Mr. Schoenrhal. Mr. Chairman, I would like to add also that that is one of my chief objects in coming here. This gasoline-pump proposition is one of the most important matters of interest. I would like to hear discussion on that.

Mr. Strmpson. Mr. Chairman, we in our State give inspector's two weeks' vacation every year. We are sent here for the purpose of getting the benefit of this convention, and if we want pleasure we take that during our two weeks' vacation. I think we ought to get the benefit of this convention and thrash out the thing while we are here. We are here for the benefit of the States, at their expense, and those who are here seeking pleasure can regulate that themselves.

Mr. Sciromenthal. I move a reconsideration of the previous motion so that the original program may be followed as closely as possible.

The Acting Chamman. Gentlemen, you have heard this new motion. Is there any further discussion? The motion is that we shall go through with our program as rapidly as possible in order to allow delegates who have not seen Washington to do so. If you favor this motion say aye; contrary ninded, no.

(The motion was agreed to.)

The Acting Chairman. The chair appoints Mr. Hanson, Mr. Schwartz, and Mr. Cluett as the committee ou nominations. They have all been in the business a long time, are thoroughly familiar with the procedure, and are also acquainted with most of the members, I think.

\section{SHORT WEIGHTING IN ICE SALES, BY LESLIE C. SMITH, SECRE- TARY, NATIONAL ASSOCIATION OF ICE INDUSTRIES.}

Before we can arrive at a complete understanding of the importance of any industry, and therefore at the scope or meaning of the evils which may creep into it, we must first know the measure of its relation to the public at large. Particularly is this true when official or governmental authority interests itself in investigation or inquiry in the performance of its duty to that public.

The value of ice and refrigeration to human welfare has not been generally understood. The evolution in modern methods of living. the congestion of peoples in cities, the very trend of American life. 
have made ice an absolute necessity to health, comfort, and happiness of our people. Cool cellars, sping houses, wells of cold water, and dry attics are things of the past. Instead of these there has come up the ice box and the refrigerator. Probably 90 per cent of our ineats and vegetables have come into contact with refrigeration of some sort before they are offered to the consumer. That means that they must be kept cold to prevent deterioration before actual consumption. The expense of such refirigeration is an item of cost in the prices we pay for perishable foodstuffs. Thus in large measure we are all affected by agents of refrigeration and their costs.

A potent guide to the actual necessity of a commodity of general consumption is in the value which social workers and child-welfare societies place upon it. Their contact is with the great mass problem of society and of government, and their initial requirements are invariably milk and ice.

Accepting, then, its importance and necessity, we should the more carefully seek to protect its supply from evils and distortions. Public-health protection has long since demanded sanitation and purity in ice trafficking, just as it has in water supply and in milk, meat, and similar products. But as yet slight attention has been given the elimination of waste and suppression or prevention of unfair practices in its handling, which directly affect its cost, particularly to the classes least able to bear the burden or to protect themselves.

The most flagrant evil in the selling of ice to the ultimate consumer is the practice of giving short weight. It is the one which ice companies themselves find most difficult to control. It is undoubtedly true that origin of the evil was coincident with early methods of procuring and supplying ice. Uniformity and standardization were matters of slow development in this industry. Men were employed for low wages and were, if not actually expected to cheat in order to round out the return to themselves, at least not punished for doing so.

But the ice industry has grown and developed until now we have been told it stands ninth on our list of great commercial activities. The best estimates of the Census Bureau place the annual sales at about $50,000,000$ tons, and we believe $\$ 8$ investment per ton sold is thoroughly conservative. Careless methods of production and distribution have been largely discarded. Labor has been standardized in this business as in practically all others. All reputable dealers in ice want to deal fairly with the public. They desire to give full weight to all customers. Most of them have worked out systems of selling and collecting in the effort to eliminate any possibility of unfairness or dishonesty on the part of their delivery inen. And the weakness of these systems has lain and still lies in the failure of the public to cooperate with the companies from whom they buy.

It is a bold statement that the public does not want full weight, yet it is true. They want overweight. In petty ways they seek to accomplish this by some form of bribery to the delivery man. The man is charged with all the ice he takes out and must account for it. Therefore, the only way overweight can be secured for one is by cheating or short weighting another. That means that when, through any medium, one consumer receives more than he pays for he is actually taking the money the driver receives, not from the company, but from the other consumers. The reasoning seems to be that the loss falls upon the company where it is insignificant, whereas in reality 
it must be borne by one's neighbors. A few cents per day to each of some 25,000 drivers merely adds that nuch to the cost of ice. Every transaction that permits of a dollar being withheld from its proper application increases the cost to the public.

The most common practices of consumers is the giving of liquor or other dainties of the ice box and insistence upon paying cash for the delivery when the company's plan calls for payment by coupon. This makes it possible for the delivery man to keep all or part of the money, and thus secures the desired overallowance. If the driver fulfills their expectations, all the overweight they receive is taken diretly from =omeone else. He has no chance to deceive the company. It must be understood that we are not making the ice man the worst of all laborers; yet the opportunity is frequent, and the refusal of the public to assist the companies in minimizing it is the direct feeder to it. If the public would follow the plan and abide by the regulations of the companies, there would be no market for the ill-gotten oversupply of the driver, and therefore no inducement for him to be unfair to anyone.

Regulations calling for weighing each delivery and for penalizing false weights exist in many communities, yet they are merely in line with the companies' wishes. They do not reach the tacit agreement between driver and customer.

Another phase of the question is that of the itinerant dealer, known to the trade as the ice peddler. He has merely the investment of a horse and wagon. He accepts no responsibility of supply for even his own limited trade. If there is a shortage in the narket, the peddler escapes all criticism, while the responsible company bears all the odium of public censure. He has heavy investments in storage houses, manufacturing plants, and delivery equipment, which must be maintained all year around in order to secure a supply for the summer months. His season of profit is limited to the lieated period, whereas he actually suffers loss during the major portions of the year.

Nor are all peddlers dishonest. But the margin between wholesale and retail prices is usually not sufficient to permit a profit from distribution only. The result is dishonesty. The class, as such, is irresponsible. In fact, most of them are drawn to the occupation by reason of this very opportunity for graft. Their sales must reach into business of goodly proportions, even under the most fertile opportunities. The ice industry does not differ materially from any other. If you allow a dealer in any class to stand on a market with a measure containing a false bottom, yoll will soon make rogues of the other dealers or drive them from the market.

The well-organized companies have sought faithfully to protect the public. They ask them to buy coupons and to exchange these only for ice. Cash sales by drivers are frequently forbidden entirely. If the best results have failed of accomplishment, it has been because the public and the officials of whatsoever unit capacity have failed to comprehend the seriousness of the situation. It is even next to impossible to convict a man who has been actually detected in the wrong, because the customers defrauded will not appear against him. They think he has not done much harm and that they, each one, have been the gainer by his lapses. If they thought the company was reaping the profit from these peculations, the protest would very 
soon suggest the remedy. They ignore it in the individual because they do not grasp its vast extent.

Absolute dealing in ice is difficult. It is almost impossible to give exact weight in each transaction, because there is no practical method of cutting a block of ice into equal units. Try as one may, it will act contrary at times and any piece may weigh slightly more or less than was intended. If the excess is cut off, it is absolute waste. The difference can not be adjusted in cash, because of the low value of ice per pound. But if there be no chance for personal gain to the delivery man the give and take in weight will balance itself. This course has been argued and approved through the courts of Missouri.

Nor will the policy of tolerance entirely solve the difficulty. It may protect the honest, but it would leave open the opportunity for studied and systematic operation to the dishonest.

There seems to be ample protection for the public in practically all other branches of trade, and ice dealers will welcome any assistance toward the goal of absolutely fair treatment of the public upon a basis of sane and justifiable conduct of a business at once vital and legitimate. We welcome such inquiry as this Bureau is making because we want to do the right thing, and that only. Our various associations, State and national, stand ready to lend their utmost to your successful solution of this and all problems which touch our industry in its intimate relation to the American public.

\section{DISCUSSION OF ABOVE PAPER.}

The Acting Chamran. Mr. Smith's paper is now before you for discussion.

Mr. Schoenthal. I see the speaker divides the vendors into two classes, one the producer and the other the itinerant vendor. He tells us that the producer, the manufacturer, issues coupons and desires these coupons to be used. I would like to ask Mr. Smith if he does not think the method by which these coupons are issued stimulates dishonesty from the fact that these coupons are in nearly every case made to represent 5 or 10 cents' worth of ice, instead of the number of pounds the consumer is receiving.

Mr. Lesure C. Smrtr. For the benefit of the gentleman I would say that that has been until very recently a large practice and one just now being discountenanced in favor of the substitute suggestion you make. Since Mr. Wilkinson is representing the City Ice Delivery Co., of Cleveland, we might have lis opinion; his company is perhaps the largest developer in the matter of coupons, and if your body desires that the modern method of issuing coupons be laid before you, Mr. Wilkinson will be very glad to do it.

Mr. Hanson. I would like to ask the gentleman a question relative to ice scales: Is it the custom in the city of Cleveland for the ice companies to have these retail scales graduated to 5 pounds, or 2 pounds, or 1 pound?

Mr. Lestie C. Smrth. Mr. Wilkinson represents that individual company. I am from Chicago, representing the national industry.

Mr. Wilkinson. They are graduated to 1 pound.

Mr. Hanson. Is that universal in the Middle West?

Mr. LesLie C. Smith. It is universally so in the industry. I should like to explain to the gentleman that that is in no sense a protection 
to the customer. The cutting of a block of ice, whether it be a 300 or 400 pound cake, is at the best a speculative operation. If the consumer gets a piece of ice purporting to be 50 pounds and it is 52 , the weighing of that piece of ice has meant absolutely nothing to him. $\mathrm{He}$ is getting cut off of 2 pounds if it weighs 48 pounds; he is not getting within 2 pounds of what he pays for and it adds to the cost to the consumer. If he knew it weighed 48 pounds he would in all probability reject the piece of ice. The weighing of ice is in no way a positive protection or safeguard against shortage.

Mr. Hanson. Suppose an iceman has come to my house, and for some reason or other I have complained to the local sealer of weights and measures and he has found a shortage. Assume he is the only iceman in that section of the town. If he refuses to give me ice, is there a law that makes it mandatory for him to give me ice, provided I tender him 5 cents, or a multiple thereof?

Mr. Lesuif C. Smith. There is none.

Mr. Hanson. I want to say as a matter of information that the great old Commonwealth of Massachusetts has a law that if any ice dealer refuses ice to any person offering a 5-cent piece, or a multiple thereof, he is liable to a criminal prosecution and subject to a more severe fine than if he gave short weight.

Mr. Lesire C. SMrth. That is a matter of statutory regulation?

Mr. Hanson. Yes; I wanted to call attention to it.

Mr. Mikeseru. I understand Mr. Smith to say that the act of weighing a piece of ice is no protection to the consumer?

Mr. Lesume C. Smith. Yes.

Mr. Miresel. I can not agree with that statement. I understood Mr. Smith to say that if a piece of ice weighed 2 pounds more than the man paid for there is no advantage to the consumer. I figure that, literally speaking, this is a natural advantage to the consumer. On the other hand, I also figure that if he pays for the 50 pounds of ice the coupon calls for and only 48 pounds of ice are delivered he suffers a distinct loss.

Mr. Wilkinson. I do not know whether you men realize the situation the ice company is up against. There was some discussion among a good many persons as to whether the association should present all these facts before the weights and measures officials of the United States, and you will be surprised what a large percentage objected. Why did they object to Mr. Smith coming down here to present this matter and asking your cooperation?. The reason they objected is because the weights and measures officials in a good many of the States of the Union have attempted to apply the same methods to correcting short weight in ice which they try to apply in the case of potatoes and apples, and meat, and flour and sugar, and gentlemen, it will not work. It absolutely will not work. Even if you put absolutely accurate scales on every ice wagon, and in most towns they are there and they have got the seals on them to show that they will weigh accurately, they will never be used. You can not follow an ice driver and make him use them. What is the reason? When he puts a piece of ice on that scale, he is the only man that ever sees it; nobody else ever sees that indication. He knows before he hangs it there that the lady is going to get that piece of ice whether it weighs a pound more or a pound less. At a big apart$155530-20-6$ 
ment house he will cut off a large piece and put it on his shoulder and take his ice pick and chop off pieces as he goes around. If he is honest he will not miss any of these more than a pound, or a pound and a half. Any honest driver can give honest weights, especially with machine ice; he may miss it to-day but to-morrow he may give half a pound more. Your neighbor gets half a pound of your ice here to-day, and next day you get a half a pound of his ice. That is insignificant, and that is where weights and measures officials have fallen down in trying to get honest treatment for the public. They have been bothering themselves with those pounds and half pounds when that is no evil at all. The only way we will be able to get this thing corrected is to work out some cooperation with the companies. Let the companies know that you are going to take part in it. The independent man supplies a good many people, and when you find that that man is giving short weight here and there you know that somebody is going to get the ice to make up for the short weight. If you follow him to half a dozen customers, and one gets a pound more, perhaps the next day he will get a pound short.

Mr. Tucker. I do not know what the system in use in the different States is, but in Indiana we allow a tolerance of 2 pounds on our ice scales. We realize the fact that the iceman in cutting his block of ice saws down so far and then splits it. It is practically impossible to make that ice split square through, but we do require that when they start out with a 300 -pound cake of ice they shall sell only 300 pounds. We have taken it up with the ice dealers of the State and require them to take care of shrinkage from the time of loading the wagon to the end of his route. We find that the average 300 pound cake of ice in our State will overrun 5 or 10 pounds, and we are getting splendid results from the icemen and satisfaction for the consumers. We realize that it is impossible to follow the iceman from the beginning of his route to the end of it, but in checking up his loads quite frequently after he leaves the ice plant, we find that he has about the same amount of ice he is supposed to have. He can not cut his pieces to the pound; but the average iceman is like the average butcher, or the arerage man in the drug store; he can almost guess to a grain, and the average iceman, after he is on the wagon for a short time, will know about what the ice is going to weigh.

Mr. Guardia. As a representative of an ice-scales company I should like to say that ice scales are made in capacities of 125 pounds by 1 pound, 200 pounds by 2 pounds and by 5 pounds, 300 pounds by 5 pounds, and 400 pounds by 5 pounds. We find that the average scale called for runs 200 by 2,200 by 1 , and 300 by 5 . We find very little sale for the 125 by 1 pound, and limited sale for 400 by 5 pounds.

Mr. Schwartz. Mr. Chailman, I would like to ask Mr. Smith regarding the hygienic, or manufactured, ice. In manufacturing the cakes-that is, in freezing-what is the weight of the cake of hygienic ice supposed to be?

Mr. Lesire C. Smith. Either 300 or 400 pounds, generally speaking. They run about 310 and 415 pounds.

Mr. Schwartz. All over the country?

Mr. Iassire C. Smith. Universally. 
Mr. Scriwartz. I did not think that they did. Of course, in New Jersey we have just enacted at the session of 1919 an ice law requiring all ice to be sold by weight. In addition to that, the statute requires that the ice companies must have the ice tongs weighed by the sealers of weights and measures and the weight stamped on them, because there is a variation in the weight of ice tongs, and the dealer sometimes gets the benefit of $2 \frac{1}{2}$ or $3 \frac{1}{2}$ pounds of tongs with the ice, which is not part of the commodity. It requires that the ice tongs must be brought to the different superintendents of the department for weighing, and we seal these with the weight placed on the tongs. Then he must weigh the ice. We do not follow this 1 pound or half pound shortage. That is not the idea. We realize that it is not like butter or cheese. You can not cut it accurately. This act has been on the statute books only since April of this year. We find the dealer is not always the honest man you have been trying to show him to be to-day. Instead of giving the 300 or 310 , his cakes are weighing only 270 pounds, and when the retailer comes up to the platform to get that ice he gives him eight cakes to the ton. The former puts the eight cakes on and goes out selling it.

Mr. LesLie C. SMirh. Does he sell that cake by weight?

Mr. Schwartz. Yes; under our law, he must sell it by weight, but that is the custom they have up there, and they are still trying to do it. He receives the eight cakes for a ton, 270 pounds to a cake, but when he sells them he charges for 300 pounds. He is making one block on his eight. That is the practice we are going to stop in New Jersey, where we find some of the icemen are not honest.

Mr. LesLIe C. Smith. In a few of them-the modern companiesthe trend now is for weighing, not measuring it at all. The driver takes his load out by weight, not under cake measurement.

Mr. SchwarTz. We are compelling them to do that.

Mr. Leslie C. Smith. The general trend of the trade is in favor of that, and that is very generally done. I was not thoroughly informed about your New Jersey situation, but that is coming to be a general practice.

Mr. Mrressid. The cake of ice never ceases to be 300 pounds from the time it leaves the shed until it is delivered. From the dealer's standpoint ice does not melt. What I want to call the attention of the conference to is the argument of Mr. Wilkinson. I submit to this conference that his argument is a hit-and-miss policy, and not a business proposition. In the entire argument he admitted that. The other gentleman, Mr. Smith, has a business proposition. Mr. Jones loses in his ice and Mr. Smith gains in his ice, but neighbors change and one ceases to live there. The law of compensation will not fit in in Mr. Wilkinson's argument. In my experience my ice coupons call for pounds, and naturally I get the proper weight myself, because they happen to know me; but I know there are others in my community who never get the poundage, and the method that Mr. Tucker uses to check up on the iceman is not at all times practicable. I sometimes check when the iceman knows nothing about it. A good way to check up is at the back door of the housewife to find out how many times the law of compensation comes in.

Mr. Bove. May I be permitted at this time to explain to this convention the difficulties and trouble which I had during the last sum- 
mer in my city of Portland, Me. Shortly after I assumed my office, gentlemen, I began to receive numerous complaints from the housewives regarding short weight of ice. Of course, I did not have experience in my position, and immediately I consulted with my superior, the deputy State sealer of weights and measures, Mr. Levi $\mathrm{S}$. Pennell. This is a serious propositioon, it is true, and the idea is this, that the complaints I received were not of overweight, they were of underweight from 5 to 10 pounds. In my city of Portland, the ice company sells ice at 15 cents for 50 pounds. Now, the customers did not receive the 50 pounds, but anywhere from 5 to 10 pounds short. Last February, in the city of Portland, the argument was that during the war the labor situation was so serious they could not hire sufficient men to do the work. Now, then, our argument was this, that it was not right for the icemen to give 40 pounds for 15 cents; if it weighed 40 pounds they should charge accordingly; if 50 pounds, then charge 15 cents. I do not believe I can agree with the gentlemen that stated just a while ago that the sealers of weights and measures have fallen down. It is not the practice of the sealer of weights and measures to persecute the ice company. I have learned from Mr. Hanson, of Massachusetts, that they have a law there that they must sell ice to customers. We have not that law in the State of Maine, and I am glad I learned of it this morning. One particular customer made a complaint in regard to short weight of ice, and the next morning the dealer refused to sell ice to this particular customer. Do you call that a square deal? Of course not. I had more trouble with the ice companies last year than I did with any other class of dealers.

Mr. LesLie C. Smith. We began this discussion by admitting that there is an evil. I am not here to defend the proposition that no such evil as short weight exists. We admit it and are here to offer all the assistance of the ice industry to eliminate that evil, all the assistance we can bring to you, and to ask you all to cooperate with us. There is dishonesty in the business; there is short weighting in the business. We know that perfectly well; but I do maintain and I insist that the element of correction must not be confined to any hairsplitting processes. We must get down to this thing on a broad business basis, treat it as a wrong to the community, educate the public to assist us to bring to prosecution and punishment those men that are dishonest and unfit, and encourage their assistance and their support in the adoption and following out without deviation the plans which the companies, the State authorities, and you gentlemen in serious authority may institute for their own protection. That was the gist of the paper I read to you; that is the plea which I make.

The Acting Chairman. I think this is the time to close this discussion. Unless there is opposition to this, we will go on to the next paper. I think it is a good thing to have these gentlemen come down here and present their side. Unless there is a decided desire to continue, I think we had better stop the discussion at this point.

Mr. Mikeselu. I appreciate the fact that I have intruded upon the convention, and, except to answer Mr. Wilkinson, would not have had anything to say, but I do not believe the discussion should be cut off. 
Mr. Schwartz. I make a motion that we put it in cold storage until luncheon.

The Acting Chairman. How does the convention feel about it? Do you want to carry oll discussion or proceed with the program? All in favor of going oll with the regular program signify it by saying "Aye"; contrary "No."

(The members expressed their desire to proceed with the program.)

INSPECTION AND REGULATION OF TAXIMETERS, BY GEORGE F. AUSTIN, CITY SEALER OF DETROIT.

Mr. Chairman and gentlemen of the conference, before proceeding with my somewhat brief paper I desire to take this opportunity of expressing my sincere pleasure at again meeting with the members of this convention to discuss the vexing problems that we are facing from day to day. It is a pleasure to me because I am interested in the standardization of weights and measures, and it is also a pleasure to renew the acquaintances which I have made during the past 8 or 10 years. While I can not boast of being a representative of a great State, Commonwealth, or Empire, I am proud to be the representative of one of the best and most enterprising cities in the United States. I refer to the city of Detroit in the great State of Michigan.

It has been hard for me to decide on a subject to present. It seems that such subjects as the majority of delegates attending this conference are most interested in have been very ably discussed. However, in looking over a list of the work with which my department in the city of Detroit is engaged I find that for the past 10 years we have been charged with the inspection and regulation of taximeters, and I am advised that some of the other large cities have had supervision over this branch of public service for even a longer period. Yet, to my knowledge, no word has come to this conference concerning the subject, and, as the conference is in a measure a clearing house for the weight and measure officials of the entire country, I will, with your indulgence, endeavor briefly to outline the method used in the inspection of taximeters in the city of Detroit and, so far as I am aware, throughout the entire State of Michigan. This is not for the purpose of imposing our system upon the association, but in the hope of provoking a discussion of the subject which may tend to simplify and better the present conditions.

Since the recording mechanism of the meter is connected by a flexible cable and a system of gears with the cab wheel, which furnishes the motive power, it is obvious that the degree of accuracy in recording the mileage and the fare to be collected depends very largely upon the care and accuracy displayed in determining the circumference of the cab wheel in service and from this the number of revolutions which said wheel will make in traveling a given distance. This is rendered difficult owing to the different degrees of inflation maintained in tires in usual service. Hence it is necessary that the number of revolutons per mile of the various sizes of tires be predetermined and arbitrarily fixed as a basis for further computation.

The method which I use in arriving at this base measurement is to carefully mark the wheel of each cab in service and require the driver to move his cab forward one complete revolution of the 
wheel, measure the distance, and take the average of all wheels equipped with a certain-sized tire as the measurement to which the meter must be adjusted for taxicabs using that size of tire.

Example: In a 35 by $4 \frac{1}{2}$ inch heavy-duty tire the average circumference of all wheels measured equaled 108.38 inches; 63,360 inches divided by 108.38 equals 584.6 revolutions per mile, and the meter is required to be adjusted accordingly.

In like manner we determine the revolutions for the followingsized tires:

36 by $4 \frac{1}{2}$ inches, 560 revolutions per mile.

35 by $4 \frac{1}{2}$ inches, 584 revolutions per mile.

34 by $4 \frac{1}{2}$ inches, heavy duty, 600 revolutions per mile.

34 by 4 inches, 609 revolutions per mile.

33 by $4 \frac{1}{2}$ inches, 626 revolutions per mile.

32 by $4 \frac{1}{2}$ inches, 631 revolutions per mile.

32 by 4 inches, 650 revolutions per mile.

31 by $3 \frac{1}{2}$ inches, 660 revolutions per mile.

30 by 3 inches, 678 revolutions per mile.

SEALER OF WEIGHTS AND MEASURES

173

REPORT OF TAXIMETER INSPECTION

Detroit Toxicob Co.

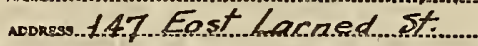

мвтея ко. 727

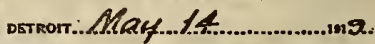

\begin{tabular}{|c|c|c|c|c|c|c|c|c|c|c|}
\hline 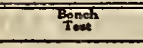 & Reocises & Fiti & 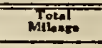 & 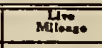 & 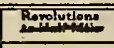 & \multicolumn{3}{|c|}{ 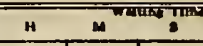 } & \multicolumn{2}{|c|}{ Monos } \\
\hline Roendinin at Finleh & 793 & 2665 & $748-1$ & 581 & 39753 & \multicolumn{2}{|c|}{ Arrival } & \multicolumn{2}{|c|}{ z $\leq p$ m. } & \\
\hline Rooding aet Steart & 174 & 2664 & $744-1$ & 577 & 37329 & 2 & 34 & 10 & $\pi_{2}$ & 100 \\
\hline Disomones. & 19 & 1 & 4- & 4 & & 2 & 38 & zo & $Z$ & 10 \\
\hline Compuruston & $\begin{array}{r}19910=1.90 \\
1.20+500772\end{array}$ & & & & & 2 & 42 & 20 & 2 & 20 \\
\hline Yrooo Roedilne & & & & & & 2 & 46 & 30 & $\sqrt{2}$ & 30 \\
\hline$P=$ & & & & Rer.per & $d / e=600$ & & & & & \\
\hline 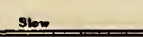 & & & & & & & & & & \\
\hline Trend & Numbor & Dhe-1 & 2000 & $\begin{array}{l}\text { Smatl } \\
\text { coser } \\
\end{array}$ & Romeluenters & \multicolumn{2}{|c|}{ 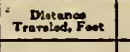 } & $P_{m e}$ & \multicolumn{2}{|c|}{ slone } \\
\hline & 46 & $34 \times 4 \% / 2 k, 0$ & & & 2404 & \multicolumn{2}{|c|}{21155} & & \multicolumn{2}{|c|}{35} \\
\hline
\end{tabular}

FIG. 1.-Report of taximeter inspection, city of Detroit.

Our method of inspection is as follows: A taxicab is brought to the garage with the meter affixed thereto; we then jack up the cab wheel to which the driving pinion is affixed and the same is connected to a machine operated by a motor and equipped with a revolution counter. A reading is then taken of the revolution counter, also the various readings on the meter to be tested, all of which are properly recorded on blanks prepared for that purpose, a sample of which is illustrated herewith. The flag is then set in position to indicate that the meter is engaged, and at the same time the cab wheel is put in motion and the current applied to the motor. The test may be concluded when the money value for any desired distance has been recorded. A reading of the revolution counter and other values indicated by the meter are again taken and recorded as before, and without changing the position of the flag the meter is subjected to a test of several periods of waiting time. If our test for mileage, waiting time, and money values prove to be correct 
we seal the meter on the cab with a wire seal and seal the transmission at the cab wheel.

A metal tag is riveted to the flag of the taximeter and numbered to correspond with the number on the inspection certificate, which is made in duplicate, one of which is filed in the office and the other is furnished to the owner of the cab. A certificate of approval is also posted in a conspicuous place on the inside of the cab for the information of the public.

We allow a maximum tolerance of 2 per cent for meters running slow, but make no allowance for those running fast, for the reason that taximeters register the fare for each one-quarter mile in advance, and in case a meter is fast it would record the fare for the second one-quarter mile before the first quarter had been traveled.

We also have two 1-mile courses surveyed which we sometimes use in connection with our inspection work.

\section{REMARKS BY F. REICHMANN, FORMER STATE SUPERINTENDENT OF WEIGHTS AND MEASURES OF NEW YORK.}

Mr. Chairman and members of the conference, by agreement with Mr. Schmitz, I am entitled to only two and a half minutes. The paper that I was going to read you can all read in the proceedings. I will tell you briefly what it is.

In order to be successful in any kind of business, it does not make any difference whether it is the business of weights and measures or a business concern in private life, there are two things you have to know: First, you must know who is your official boss, and, second, what is your job. I suggest that everybody hold a little period of introspection and answer those two questions for himself for his own satisfaction. If you organize your department-and in this paper I am giving you some organization pointers from the standpoint of activity and personnel and its relation to the department activities-if you will organize your department and have the chart before you all the time so that you know who your official boss is, because I know a lot of you are in political life and there are other bosses than official bosses, and what is your job, you will never become stagnant and will appreciate the economic value of weights and measures and never degenerate simply into tinkerers of scales. Thank you, gentlemen.

Mr. Barnard. I am afraid I will have to make a little complaint at this time. I think our old and much respected friend, Dr. Reichmann, has short weighted this convention.

\section{SALARY SYSTEM VERSUS FEE SYSTEM OF INSPECTION, BY GEORGE H. STAPLES, INSPECTOR OF WEIGHTS AND MEASURES OF MINNE- SOTA.}

The fee system of weights and measures inspection-that is, the charging of a fee for inspection of weighing and measuring apparatus-presents four different phases, to wit:

First. Where the inspector depends entirely on the fees collected as compensation for his work.

Second. Where the inspector's salary is a stated sum and the fees that he collects go into a fund which is drawn upon to pay the fixed salary. 
Third. Where a fee is charged only under certain conditions, such as a special test, the regular annual inspection being free of sharge.

Fourth. Where the officer doing the inspection work draws a fixed salary from State or municipality in some other official capacity and is permitted to charge and retain a fee as sort of compensation for the extra work involved because of the weights and measures inspections.

As far as I have been able to look into the matter, I have learned that practically all of the above-named systems are now or have been in vogue in different parts of the country, but since the title of the paper suggested for me seems to cover only the first-named phase of the subject, I will try to stick to that text under the given heading, "Fee system versus salary system of inspection," this, of course, dealing with the subject of weights and measures inspection.

The fact that the most progressive States in the matter of weights and measures supervision and regulation have abandoned the fee system would of itself indicate the unpopularity and lack of equity in making an individual charge for testing weighing or measuring devices, because undoubtedly most of the States and municipalities within a State were at one time or another on some sort of fee system, and must have been influenced by good and sufficient reasons in making a change.

I have heard it argued that under such a system as indicated by the subject title of this paper-that is, the fee system as the total compensation for the inspection work-there would be a tendency to greater effort and activity on the part of the inspector because of his natural desire to collect money enough to make an attractive compensation, and that this would result in extra benefits to the public in general because of such extra activity; but there are, in my opinion, based on some study of the matter, ample reasons to advance in answering such an argument.

In modern weights and measures work the inspector should be as independent as possible of any direct relation in money matters to the people who own or operate the weighing or measuring apparatus that come under his official supervision, and thus avoid entanglements of individual and private interests which would unavoidably to a greater or less extent affect the general efficiency of the inspector in his duties, resulting in a proportionate loss to the whole public who are to be served.

As to there being an extra amount of work done by an inspector under such conditions, through possible feverish desire to collect many fees, it is very clear to me that the extra amount of work apparently accomplished might only in fact mean larger figures on paper, for, since an inspector working on a salary system must be given the presumption that he is doing a full and proper day's work, it would follow as a mattter of logic that the extra amount of work done in a number of places visited or number of pieces of weighing or measuring apparatus inspected under the fee system, as against the salary system, would plainly indicate more or less slighting of the work in order to cover more ground.

Where a fee is charged, especially where it goes directly as an amount to compensate the inspector in his official duties, it is impossible to avoid some suggestion of "graft," no matter how unfair and 
groundless the intimation may be, and, since equity and aboveboard dealing make up the fundamental principle of weights and measures supervision, every effort should be made to avoid any possible suggestion of that modern word of unsavory meaning in any public work or utility.

Weights and measures inspection results in a positive benefit to every individual in a State or smaller community, and it seems to me but fair to have the expense of the inspection borne by all who receive the benefits, thus making exceedingly small the individual financial burden, rather than having it borne by a comparatively small class who happen to be engaged in the business of buying and selling, an eminently respectable and necessary occupation in modern life.

To sum up in conclusion, I will state that the "fee system" is antiquated, always savors of "graft," is dangerous from a politicaleconomy point of view, places a burden on a small class alone in the community, greatly adds to the troubles of an inspector in the field, and hinders the work in general.

\section{APPOINTMENT OF COMIMITTEE ON RESOLUTIONS.}

The Acting Charrman. The committee on resolutions will be $\mathrm{Mr}$. Webster, of New Hampshire; Mr. Gregg, of Texas; Mr. Smith, of Wisconsin; Mr. Holwell, of New York; and Mr. Holbrook, of the Bureau of Standards.

THE PRESENT MOVEIMENT TOWARD OBTAINING STANDARD SHIP. PING CONTAINERS FOR IMARKETING FRESH FRUITS AND VEGETABLES, BY F. P. DOWNING, BUREAU OF IMARKETS.

Mr. Chairman and gentlemen: For the last two years I have been associated with the Bureau of Markets of the Department of Agriculture, and for the benefit of those who are not familiar with the work of that Bureau I might say that the Burean of Markets studies and investigates all of the various problems connected with marlieting. My work for the past two years has been a study of the different types of fruit and vegetable containers-shipping containers, if you please, gentlemen. I have arrived at a few fairly definite conclusions which I want to bring before this conference.

In taking up this question, I want to treat it, perhaps, from a little different point of view than it has ever been treated before in a weights and measures gathering. I want to treat it from the point of view of the commodities that go into these containers. Did you ever stop to think of the different living conditions to-day and 25 or 50 years ago? Twenty-five years ago all of our perishables came from within a few miles of the market. To-day, even in the winter time, you can get strawberries from Florida, radishes and onions from Louisiana; you can get lettuce and cauliflower from away across the continent, from California. Now, then, this means, first of all, that we must have some particular type of shipping container for getting these commodities to market. At first there was no regulation of this important question. The different growers and the different merchants in the different sections of the country used their own ingenuity in working out types of packages with the result you all 
know. All you need to do is to go into any one of our large markets to-day and you will see hundreds of different types of shipping containers. A few of the unscrupulous dealers took advantage of this chaotic condition and began to cut down the size of their containers to the detriment of legitimate shipping interests and to the detriment of the public. Some of our larger cities and some of the States wero the first to notice this, and they began to pass regulatory laws.

One of the most important packages from the standpoint of the consumer, because it goes directly to the consumer, is the berry box. Massachusetts and New York were among the first to pass berry-box laws; but there was a conflict from the beginning. Massachusetts provided for a standard box; New York provided for a 7 per cent tolerance, with the result that as far south as Tennessee the New York shippers had boxes that were 7 per cent short of the quart.

Out in Kansas they regulated this proposition in the interest of the berry grower by legalizing the wine quart, and I believe that law is still on the Kansas statutes, although I am pleased to say that even the inanufacturers of Kansas are making standard boxes. It does not pay them to make a short box just for the Kansas trade. In a recent investigation $I$ made in that State $I$ find this to be the case.

California is peculiar on the berry-box situation. They have a law out there that provides for the quart, pint, and half-pint boxes, and at the same time three other containers, a shallow half-pound, a deep half-pound, and a three-fourths pound box. They go on the assumption that the fairest method of selling is by weight, and I believe they are right in most instances; but berries can not be handled in the way that you handle potatoes; you must establish a standard container there.

As I take it, no regulatory law on packages considers the fact that these packages should not resemble one another too closely, but in California they are beginning to realize this, for the last legislature has a bill up proposing the elimination of the boxes standardized by weight, and providing for only three standard sizes. The national law which I am called upon to enforce provides for those three sizes, but in the enforcement of the national statute $I$ have a distinct advantage over those enforcing State laws from the fact that I can go directly to the manufacturer of the package and say, "You are held lesponsible for marking the standard package." It must be standard whether it is filled or unfilled. It is easy to enforce a law of that sort.

I want to say that the manufacturers of containers are strongly in favor of standards because it is to their interest to cut out and eliminate many of the forms they now have and to standardize their machinery.

The picture I have up here [indicating] shows the condition that existed prior to the passage of the standard-container act. There are eight sizes between the 2 quart and 3 quart. The sizes are so close to one another that the consumer is not protected, since there is a very great chance for fraud to creep in. Would it not be feasible for you gentlemen to get similar laws enacted in your different States?

I find in some instances that some of these packages of intervening size are still used locally where we have no jurisdiction. Under this law the Federal Government has jurisdiction over only interstate shipments; it has no jurisdiction between points in the same State, 
so that the manufacturer in Ohio can make a $2 \frac{1}{2}$-quart basket and sell it in Cleveland, and it would not be affected by this legislation.

This condition to which I have called your attention also exists in the case of the grape basket, which we designate as the Climax basket. There used to be 12 or 15 sizes of these. Now, there are only 3 . The States are trying to regulate this condition. New York passed a grape-basket law on the basis of weight. Pennsylvania passed a law, and both of these were in conflict with the present Federal law. The State of New York, I understand, has repealed its law, and the 'State of Pennsylvania is unable to enfore its law. From personal observations I am now pretty well convinced that there are no grape baskets made in the United States except the 2, 4, and 12 quart sizes. There may, perhaps, be a few of the old stock left over.

New Jersey was one of the first States to attempt to regulate the size of containers, and those of you who are familar with the statute of New Jersey know that it provided for the bushel and certain subdivisions, but the 3-quart basket was not included. Their law, you see, is in conflict with the Federal statute. If they enforce it rigidly or do not provide for the sale of this type of basket by weight, they will not be able to get any tomatoes, berries, or peaches from Mississippi and Alabama in this size. They will not be able to get any grapes, apricots, or plums from California since these are shipped almost entirely in this basket.

The point I want to make is we must have uniformity between national and State laws. I have about reached the conclusion that if we attempt to standardize shipping packages on the basis of the bushel, and subdivisions of the bushel by two, we are going to get into serious trouble.

There are a number of troublesome problems, such as the net-weight law. This net-weight law, an amendment to the pure-food and drugs act, is an attempt to let the public know just how much they are getting in the different types of packages. It seems to me ridiculous to allow the sale of a basket weighing 7 or $7 \frac{1}{2}$ ounces. It would be better to graduate on the basis of the pound and its divisions, like 1 pound, one-half pound, 4 ounces, and so on. That applies, we will say, to breakfast foods, canned goods, and things of that sort; but when you come to perishables you have a different proposition to contend with. You can not work this thing out on the basis of the bushel and its divisions by two. Let me show you what you would arrive at. Take the type of container known as the asparagus crate. It is not any usual division of the bushel, but is standardized by dimensions to hold a certain number of bunches or a certain number of pounds of asparagus. Now, asparagus will pack best in a container narrower at the top than at the bottom. The point I want to make is that if you make them ship asparagus in another kind of container you would be passing a piece of legislation that it would be almost impossible to enforce; and. what applies to asparagus applies to many other commodities. It applies to cabbage. You can not ship all varieties of cabbage in a bushél container. You might take some cabbages and put them in a bushel, but it would be impossible in the case of large western cabbages, such as grow in Colorado. You would only get two or three of them in a basket of some shapes. 
So, we have about reached the conclusion that you must standardize the type. Let that be standardized, first, as to capacity; second, as to dimensions; and, third, as to strength. Let the capacity be such that the packages in use can readily be distinguished from one another. We should not have another asparagus crate that is only a half an inch less than this in length or width. Also, since we have an onion crate that is absolutely a bushel, we should not have another one containing a bushel and 2 quarts, or 30 quarts.

I believe it is best to take this thing up from the standpoint of individual containers. We have already standardized the grape basket; we have already standardized the berry basket and the till basket; and now, gradually, we can standardize the other baskets. We have worked out with our legal advisers a bill standardizing the round-stave basket and the hamper. There are more than 30 sizes of these baskets, almost as many baskets as there are quarts in a bushel. Now, we can get away from that by selecting only those sizes that are necessary for carrying out legitimate trade. We believe, from a thorough study of this question, that five sizes are a sufficient number, the 8,16 , and 20 quart, the bushel, and the bushel and a half.

There are two types of the $1 \frac{1}{2}$-bushel basket proposed, one of them a till basket such as is now used in the marketing of both cabbage and lettuce; the other one is a basket that has a narrow bottom. This till basket would not at all answer the requirements of another section, where they would demand something that has a wider base; so bearing in mind that in all of this regulatory legislation we must not unnecessarily disturb conditions, we deem it advisable to permit of these two sizes.

In this piece of legislation we provide that the bushel hamper shall be 15 inches across the top, 9 inches across the bottom, with a 20 -incl stave. We bring dimensions into this for a number of very important reasons. It will, first of all, be of assistance to the manufacturer to enable him to standardize his forms, enabling him to turn out the packages cheaper and to keep them in stock and, in this way, to aid the farmer. It will be of value to the trade in detecting false packages, because all they will need to do will be to put a rule on the package. The sealer of weights and measures can resort to the same method of test. He will not have to go to the tedious process of measuring with seed, except, perhaps, in a case in court. It will be of infinite value in working out standard loading specifications in the shipment of these packages to the market.

I do not know whether you gentlemen realize how important this is, but the railroads report that their claims for loss and damage in transit in the last year amounted to something like $\$ 100,000,000$ on all commodities shipped; that first in point of loss in transit was grain, and a close second to grain was perishables. The latter loss was largely from breakage due to failure to load packages in the cars solidly, on account of the many different dimensions; and due also to lack of strength. All the grower seemed to be interested in was something to put on the platform. Later on he held the railroad responsible by putting in a claim for damage. As a result the United States Railroad Administration to-day has appointed a committee, known as the "Blood committee," for the standardization of packages. The railroads are very much interested in this movement toward standard packages and have subcommittees all over this 
country. Their idea is to put these standard specifications into the railroad tariffs and to put a higher tariff on nonstandard packages; or to refuse to allow claims on such packages. Now, there may be some question as to whether it is advisable for the railroads to do this. Some of our shippers are saying that in doing so they are trying to exercise a function of Congress; that they are trying to establish standards. But whether it is constitutional or not, the railroads have already begun to get results. Only a few weeks ago I saw the first standard bushel hamper of cucumbers come from the State of Florida; the railroads are going to refuse to carry cucumbers in anything but that standard package.

In this proposed bill, in addition to the standards of the hamper, we are also proposing standards for the round-stave basket. Here, again, we have a similar condition. The hamper is used very largely in the South and East. The round-stave basket is more distinctly a package of the Northwest and Central States, even out as far as Texas. There are 16 or 20 different sizes of round-stave baskets; in place of these 20 sizes we believe that 4 sizes, from onehalf bushel up to 2 bushels, will be sufficient to answer the requirements of the trade, and of these 4 the first 2 will be really the main shipping containers. The $1 \frac{1}{2}$ and the 2 bushel sizes are seldom used, but are put in to forestall some manufacturer turning out something in between them.

Now, my theme so far has been the standardization of the package; but I also believe that we should go further than this. In addition to the standardization of the shipping container-and, gentlemen, if you please, allowing that shipping container to be sold as and for such container-we should also enact legislation providing for the sale of dry commodities by either standard weight or by count when removed from such containers and sold at retail and when sold in bulk. I believe this association a number of years ago went on record as favoring sales by weight or by count, but at that time you did not take into consideration the need of having a standard container. Now, I think it is a foregone conclusion that we must have containers. A bushel onion crate holding 2,150 cubic inches will not hold 57 pounds of onions, which is the legal weight in a number of States; it may only hold 50 pounds. I believe if that package is well filled it ought to be allowed to be sold as such a package. If you do not allow this because you have numerous conflicting laws regulating the legal weight of dry commodities, you are going to bring about conditions like this. A package of this sort, marked "One bushel" under the net-weight amendment, goes into New York, where the legal weight is 57 pounds, with but 50 pounds in it. The New York inspector says, "You can not sell that for a bushel; it contains only 50 pounds." What is the result? The result is you must stamp out the "One bushel" label on it and make it read "50 pounds." It simply adds to the cost because of the extra labor involved.

Standard shipping containers are here, gentlemen, and we have to recognize the fact. I believe that the legal weights on all of our dry commodities ought to be revised-I am almost tempted to say, abolished-so as to get uniformity; revised on the basis of the number of pounds in our standard shipping containers. When you ship 
a commodity, you can not ship it heap measure, because you must have the cover on; otherwise there would be an enormous loss. Take the hamper used extensively in New Jersey for marketing sweet potatoes. When that package is well filled with sweet potatoes and the cover put on so that it is tight, I believe that that ought to be the weight of a bushel of sweet potatoes and that our legal weights ought to be so revised. Now, it may be a ridiculous belief, but if we do not get some revision of this sort we are going to have this present unnecessary conflict. This, of course, is an open question, and if any of you gentlemen have any better solution to suggest we would welcome it; but the thing we want to get away from is this lack of uniformity. We want to get these laws enacted so they will not interfere with legitimate business and at the same time will prohibit or have a tendency to do away with fraudulent practices; and we find that in accomplishing this it will be working toward the standard container. We want revision of the legal weights per bushel on the basis of the quantity that will go into this specified standard shipping container.

The hour is getting late, and I do not want to go into this matter at further length, but I would like to hear from the gentlemen regarding the theory that I have just proposed. If any of you are interested in this proposed legislation on the hamper, I might say that I have copies of the bill that I will have introduced into Congress at the coming session, standardizing these packages. I might say, furthermore, that the State of Ohio has just enacted a bill standardizing the hamper and round-stave package. Mr. Mote referred to this yesterday morning.

\section{DISCUSSION OF ABOVE PAPER.}

The Acting Chairman. Is there any discussion?

Mr. Townsend. Mr. Chairman, I think the gentleman has put the cart before the horse. I think the container should be made according to the weight per bushel, and not the bushel to suit the container.

Mr. DownING. I might answer by saying that we had that matter in mind, and if you attempt to standardize on the basis of the weight per bushel you will have an infinite variety of packages. You will have any number of them. I can illustrate by California. California sells by weight. Here we have four 3-pound tins, all of different shapes and all of different dimensions. If you carry that proposition out on the basis of the bushel for all the different vegetables, you are going to have a condition almost identical with what we have here, because you will have 32,34 , and 29 quart capacity containers for holding the different legal weights per bushel of these different dry commodities.

Mr. Tucker. My first question is, suppose a man in Ohiv takes 32 quarts of berries, places them in a crate, ships them into West Virginia or Pennsylvania, and when they get there, none of these baskets are filled; they have settled down. They may have the weight but the basket is not full. That is one thing.

Mr. Downing. In this proposed legislation we have provided that the basket shall be well filled, whether sold on the basis of weight or count. 
Mr. TUCKer. Next question: Suppose a merchant buys a bushel of onions, breaks the crate, and sells them by the pound? Instead of a bushel he had 40 pounds, yet he sells them out figuring on 56 pounds.

Mr. DownING. You must take this thing in consideration with the revision of the legal weights. If you do not have some weight on these packages, it leaves an opening for fraud in such commodities as spinach; they could be put in 12 pounds, or 18 pounds.

Mr. STEWaRT. We find that in peaches. The point I make is this: They were selling peaches short in weight-we go by pounds in West Virginia - and I went to one firm and weighed their baskets. They all had 48 pounds. I went to another firm and found from 39 to 45 pounds, and the baskets apparently were full. I raised the question, and one man who seemed to know how to pack peaches said they would hold 48 pounds, and he fixed the top and made honest measure, and when he got through he had 49 pounds in the same container.

Mr. DownING. That is a further reason why you should have at least the minimum weight on the package.

Mr. GREGG. The question I want to ask is this: Reference has been made to the crate exhibited there for a bushel of onions. That crate is extensively used in my State, in which there are some 5,700 acres of early onions shipped in April and May. If a bushel of 57 pounds is put in that crate at the point of shipment, by the time it reaches St. Louis or Chicago, which are the principal markets, although some of them come east, we find that shrinkage has reduced the weight of that package down to anywhere from 50 to 54 pounds, making it less than the standard bushel of onions. We do not believe the placing of the weight on a basket of that kind would be safe for the shipper unless a tolerance is allowed.

Mr. Irvine. There is one commodity that has not been mentioned relative to the standardized package. That is apples. In shipping apples the different kinds of apples will vary 20 pounds to the standard apple box which is used out West. You can take Bell Flower apples and they weigh 35 pounds; then, there is Black Twig; that will weigh 55 pounds. The quality of the apple has a good deal to do with the price per box. The Bell Flower apple is better than the Black Twig. The latter is a hard apple and will keep, but the quality is not as good. It seems to me that if a standard container be adopted and that container be well filled, the trade will soon learn the weight of the commodity in that container. That is, the retailer will soon learn, if the standard containers are put in use. I believe in selling by weight. I do not see any necessity of defining how many pounds there should be in a bushel. It seems to me that if we attempt to weigh evenly a certain number of pounds we need not define the number of pounds in a bushel.

It seems to me that there should be sufficient punch in this convention to cause the delegates to take up the matter witl their Congressmen and Senators and get the proper legislation through to standardize these containers and make them uniform throughout the land. I believe the weights and measures officials should use their influence with their legislators in order to get these measures passed. I know I could be of some value in taking this matter up with our Senators and Representatives in getting national legislation through, and I believe every member of this convention would 
have influence with his delegation in Washington in helping to get standardized containers. It seems to me that we ought to do away with this old system. We have tried to do away with it in the West. If we see a man with dry-measure containers on his wagon, we confiscate and destroy them. We do not permit them to sell by dry measure at all, but we do recognize standard containers. Our law provides that the standard adopted by the United States Government shall be the standard in the State of Utah. We took that measure up at the suggestion of Mr. Holbrook and embodied it in our law. When the United States Government enacts a law regarding standard containers it automatically becomes the law of Utah. I believe if every law should contain that clause we would soon get uniformity of standards and do away with this proposition of defining how many pounds there should be to a bushel. This latter method seems to me a ridiculous thing.

Mr. Barnard. For the benefit of our friend from Utah, I have to state that at the last conference, held in 1916, a committee was appointed to draft and present at this conference a bill largely covering the proposition he just suggested. I wish also to state that this bill, which has been tentatively prepared, also takes into consideration standardization of certain packages, the matter which our friend Mr. Downing has presented to us to-day. This bill will be presented to the conference a little later, and you gentlemen will have an opportunity to discuss the matter.

Mr. Bचск. This question is one of the thorns in the flesh of the sealer of weights and measures. Last Monday, before I started for the convention, I stepped into a little corner grocery conducted by a widow. She said, "I have a hamper here, a standard hamper, so many quarts in it." She told me it was supposed to hold 30 pounds, and I found there were only 26 . It was filled, so far as she could tell. Just recently two merchants adjoining had some standard-size hampers and there was as much as 8 pounds difference in the weights. One of them to come out even had to mark his pounds 15 cents; the other sold his at $12 \frac{1}{2}$ cents and made a profit.

I do not know what that bill covers; if we had it here I think we could discuss it, but I think our Federal Government had better pass one or more bills, and then forget some they have passed. It is one of the things I have more trouble with than anything else. We have the weights exclusively. We do not have any dry measures in Indiana. We have got far enough along to forget it. I wish the Government would make the hundredweight the standard; then forget everything else and sell by the pound. Now the commission man goes on the market, sells his hamper at the market, and nobody knows how many pounds are in it. As soon as the retail merchant gets it he has to sell by the pound. Gardeners have to work hard and are compelled to market their products by weight. I say to the retail merchant, "Deal with the men who are giving you a square deal; those men who have their goods marked on the outside with the net weight."

Mr. TraHe. For the past nine years the mayor's bureau of weights and measures of New York City have practiced the policy Mr. Downing has just spoken of, of standardizing packages, and the exhibits which he has presented here are similar to the packages which the weights and measures bureau has standardized. I.think 
the Federal standards will not go far enough, in that they will not have the authority to prevent the retail merchants in the various cities and States from repacking and using arbitrary measures which will defeat the object of the Federal package in so far as giving to the ultimate consumer a protection which the weights and measures officer desires to give at all times.

I think Mr. Downing's proposition for legislation is following the policy of the New York bureau of weights and measures in standardizing the packages. I am of the opinion, personally, that if we have a standardized package, and it is filled with a commodity that we go a longer distance in giving to the people protection than by fixing arbitrary weights. I fully agree with him that the equivalent of the bushel should be eliminated, and when the public become accustomed to the actual weight of standard capacities they will adapt themselves to that capacity and that weight by selling in divisions of that capacity; if they so desire they can sell by weight. I think Mr. Downing's proposed legislation will solve the problem. There is only one point on which I take any issue with him, and that is that it will not be necessary for the local sealer to give to those packages the supervision that he has heretofore. I have a point in mind which has been brought to my attention at this conference, and that is that a standardized package of the mayor's bureau of weights and measures, bearing a serial letter, was found to contain less than the capacity of the standardized one. Now, if the local sealer in this case had recognized the serial letter on this package and allowed it to be sold without making an examination of it, why there would have been a loss to the consumer of 2 quarts.

Mr. Buck. What are we to understand by the marking on some of these containers, these New York standards?

Mr. Tigns. The point of the marking is that the New York City approved type is the type of the United States standard capacity. We standardize as to United States capacity.

Mr. STuHr. It seems to me we have a condition here that is not uniform throughout the country. The southeln shipper sends out a hamper, and you are supposed to have a certain number of pounds. These goods reach the central part of the country, and the jobber buys them in these hampers. The retailer invariably breaks them and sells the articles by weight. It seems the most natural thing in the world that as long as the consumer is going to buy these things by weight that idea could be followed throughout the entire country. In the transaction, if a man is shipping goods green, there is a certain shrinkage. That shrinkage must be taken up before this article goes to the consumer. Consequently, it is natural that the allowance must be made. Possibly the shipper must stand a certain amount of shrinkage. You will find it in other shipments; in cattle a man shipping must bear shrinkage at the market. The shipper of vegetables bears shrinkage when they go to market. If the jobber buys by the hamper it would be standard as far as cubic contents is concerned, but not as to pounds; he would know the volumetric contents in cubic inches, but he would not know the quantity in terms of weight, yet this article is invariably broken and sold by weight. There is a discrimination in selling it by the hamper at one stage of the game and by the pound at another.

$155530-20-7$ 
In our State we have enacted a new law on that subject, which recognizes standard berry boxes, and nothing else. Consequently, it is questionable whether it would be up to us to recognize standard hampers and various other containers. We insist upon everything with the exception of berries being sold by weight. I refer particularly to apricots, prunes, and possibly grapes. It looks to me that if you are going to have something uniform, the best proposition would be to have weight throughout.

Mr. Irvine. Mr. Chairman, I believe this is a very worthy discussion and should be contilued. I think that if we adjourn this conference now and have luncheon and take this matter up afterwards it could be discussed with a great deal of benefit and with a larger attendance.

The Acting Champiran. I might state that at 1 o'clock we are expecting an officer from the Ordnance Department, and his time is limited, and I think he is going to give us a very interesting illustrated talk. I might say that I hope that everybody will be here becanse I think you will enjoy it very much.

Mr. Downing. In connection with the weight that goes into these standard packages, I want to call your attention to another bill which was before Congress at the last session, known as the Lever bill, providing for the use of standard crates for the different perishables. Now, if the Secretary of Agriculture is given the authority to work out these standards, we are going to come pretty close to uniform weight in the package.

(Thereupon, at 12.50 o'clock p. m., the conference took a recess until 2 o'clock p. m.) 


\section{FOURTH SESSION (AFTERNOON OF THURSDAY, MAY 22, 1919).}

The conference reassembled at 2 o'clock p. m., Mr. L. A. Fischer, secretary, presiding as chairman.

WORK OF THE ORDNANCE DEPARTMENT, BY LIEUT. COL. C. B. GATEWOOD, ORDNANCE, U. S. ARIYY.

Gentlemen, I appreciate your welcome and hope this paper will be of interest to you. I have a number of topics here which I will discuss more or less at random. This subject of ordnance is really a large one. It is something that I feel could not be adequately covered in anything less than a lengthy series of articles. To give anything like a full recital of the proposition as a whole I would have to go into a history of our different types and trace the facilities of the department in producing them. To understand it thoroughly, we have to go back through its history and follow it through the full development. Some developments have come very rapidly in the last few year's; others have taken several hundreds of years for their evolution.

A proper understanding of the apparatus now would depend to some extent upon the conception of the problems that have to be solved in order to bring things up to their present state of perfection. At other places the subject would be a discussion of the many engineering problems, which could be multiplied ad infinitum, because hardly anything that comes up, from a special-sized screw or special-fitting screw to the largest caliber gun, but has some engineering difficulty for which we can not readily find a solution. In the field of manufacturing and production there are many special difficulties not encountered in times of peace.

Then, to discuss the purpose of ordnance you would have to get some idea of the preparation made in time of peace in the way of accumulation of information and data, and often of material. Some of the material can not be produced quickly. When Germany started out on this program of hers recently brought to a termination, she had gone into everything thoroughly and had accumulated great masses of material. We have never considered that necessary, because of our intrinsic ability to produce them. But that should not be entirely our mainstay nowadays on account of the great variety of complicated material which is absolutely necessary. Then, in addition to that there must be plans as to the distribution of material needed in time of war, which is a big business in itself. For instance the consumption of small arms-cartridges for infantrymen aloneis a thing that kept a corps more or less busy solving the problem of getting the necessary ammunition to the front. The artillery is an even more vital problem.

To come down to recent construction of ordnance and to get an idea of what it all means, we must get a little appreciation of what 
the work of our immediate predecessors amounted to. They laid a foundation which has been lost sight of now by the superstructure of the war, but their work is there, and it counted for a great deal. In sizing up their work we must know something about the inherent difficulties in a country like this, one not prepared for war. We liad the foundation both in brains, ideas, and material.

What this country accomplished in producing ordnance and munitions has been written up more or less from various viewpoints, both friendly and unfriendly, partial and impartial. In its entirety it is something none of us can grasp, because it includes so many things. Take this illustration: We have actually spent in ordnance alone, in addition to other operations of the Government, during this war an amount equivalent to $\$ 1$ for every five seconds of time elapsing during the 1,919 years of the Christian era. That strikes me as a forcible illustration of the amount of money that has been needed. Another illustration is that our Government up to the day it entered this war had spent a total of $\$ 26,000,000,000$. That carried us through all of our 140 years of existence, including the Mexican War, the Civil War, and the Spanish-American War. Yet at the beginning of this war and during the first part of it, when we were forming our plans, we proposed to spend about thirteen or fourteen billion dollars, which was half the whole sum that the whole Government had spent in the preceding 140 years. The race was called off before we spent all of that money, and a good deal of it was saved; but, nevertheless, the amount actually spent mounted up to a great fraction of it. About 58 per cent of all the funds obtained by the Government during the war were spent for producing ordnance.

In the study of this proposition we find that preparation during the time of peace is as important as accomplishments during time of war. The nucleus we had before the war was the real factor in the problem and necessary to the war work. So our work can not be considered as accomplished now if we are to have any insurance against another war.

Taking up again our matériel, which is a most interesting thing, perhaps, with you gentlemen, there are about 100,000 separate and distinct articles that are carried in the ordnance catalogue for issuance to the troops. Among the most important are small arms and machine guns, cannon, ammunition, and explosives, tanks and trucks and other motorized vehicles and trailers, trench-warfare matériel, airplane armament, equipment both for man and beast, specialized fire-control instruments, and other special miscellaneous equipment. Explaining a little more specifically, small arms and machine guns include pistols, shoulder rifles, automatic rifles and machine guns, light and heavy, adapted to a number of different purposes, some used in the aircraft, others against the aircraft, some for development of heavy-fire volume, and others for lighter fire effects where we sacrifice fire to some extent to enable us to get greater portability. All of these different types are necessary, and each one has a distinct field. Under cannon we have guns, howitzers, and mortars of all calibers from 20 millimeters (about 0.8 inch) up to 16 inches, mounted in various ways and for all purposes from aircraft and tank use up to the type for the heaviest fortification. We have developed more or less complicated and special fire-control apparatus for obtaining accuracy of fire in the case of long-range guns, 
involving principles of optics, meteorology, and aeronautics. The expedient of using airplanes to direct fire is a part of that system. Without the use of accurate and specialized instruments our larger guns would be more or less useless.

In the group of munitions and explosives we have projectiles of every conceivable kind from the familiar small-arms bullet up to the large high-power explosive shell and the gas shell. Among the different small-caliber bullets we have many different types, such, for instance, as incendiary bullets for setting fire to airplane fabrics.

We have armor-piercing projectiles of every caliber, small arms as well as large. The infantry rifle has become a formidable weapon against tanks and artillery, most of which are armored, on account of the development of armor-piercing bullets, which make it possible to penetrate armor, and thereby get at the crews of tanks and bring down even those airplanes that are armored to protect their vital parts. In the class of larger projectiles we have specialized shells carrying thermite and other incendiary compounds and using high explosives for a maximum shattering effect. There are also explosives intended simply to rupture the shells so the gas contained therein can escape to best advantage; also explosives that are intended to set off the propelling charges to send the projectiles on their flight.

In motorized vehicles we have, of course, the armored tanks, with which most of you are familiar. The smaller of these are the twomen tanks, carrying one machine gun, such as the Ford and the whippet, capable of fairly high speed. The way they get over rough ground is an eye opener for anyone who has not seen them in action. All the successful ones now are caterpillar-tread. We have given up the idea of having armored cars on wheels unless they are railway mounts. In our present warfare you must be able to get over rough ground, since you can not always find smooth roads to go over.

Then, we have tractors of several different capacities to move the artillery. There is still horse-drawn artillery, and a great deal of it, but the tractor has proven its efficiency for the larger guns. It has increased the mobility and greatly increased the efficiency of the heavier guns. It is certainly a vital invention as applied to war.

Then, we have rolling equipment of other kinds-automobiles, fourwheel-drive chassis for ammunition, and other supply trucks of various kinds. It is necessary to supply certain definite quantities of repair parts for artillery on the front line, and these trucks and their repair facilities have enabled us to keep in action guns that otherwise would have been withdrawn to some factory a number of miles in the rear. The French perfected their requirements to such an extent that they sometimes got back into action within an hour or two a gun that had been put out of commission. A great number of them were put in satisfactory condition within a few minutes or a fraction of an hour. Our people have done the same thing, and our repair service in Europe has brought forth from the users of this matériel words of very deep appreciation, which we are very glad to get. These various tractors and trucks are often equipped to carry a full load of ammunition and also to drag several trailers. We have been mounting guns on these trailers to secure greater mobility. With the tractor or truck you can get over more ground than in any other way under the conditions we faced on the front. 
Trench warfare, which has grown up during this war, has been conducted with lots of strange apparatus, much of which did not even exist more than two or three years ago. We have hand and rifle grenades, bombs, signal rockets, pistols, and flares of different kinds. Some of the flares light up the battle ground for a much longer distance than any other source of illumination that we have been able to get. Also trench warfare has produced the gas mask and methods of using gas and the high-explosive and gas shell that are fired from trench mortars. Then there are flame projectors, some capable of throwing a stream of burning oil 100 and 125 feet; and trench periscopes and various inventions which have been used to some extent which practically enable a man to fire around a corner. This is a decided improvement over the first invention of the man who thought he could do it by bending the musket barrel, and who blew off his hand trying to accomplish it.

The armament for aircraft includes bombs of all kinds. They vary in weight from 25 pounds up to 1,600 pounds. The highexplosive bombs will make a crater in the ground and are so powerful that they even threaten the airplane itself if it is lower down than 6,000 feet. The method of carrying these bombs and of properly releasing them and knowing when to release them calls for quite a lot of specialized apparatus. We have bomb-carrying traps which hold the bombs in a certain position and drop them at a predetermined instant. These devices must be simple, since the aviator has not the time to operate any complicated mechanism; the best he can do is to shove a button with his knee. His faculties are occupied. Consequently, mechanisms have been perfected for carrying a number of small bombs which are released one at a time, so that the aviator or his observer can work the whole thing very easily. The apparatus for determining when to release a bomb is especially complicated in appearance, althongh in use it has been simplified or the aviator could not use it. Very good scientists and mathematicians and practical men have worked on the problem, but it is still inaccurate. It involves gauging the speed of the airplane and its height and also meteorological conditions. Developments are still being carried out along that line, and that is one important thing the Ordnance Department ought to see to now, since we all agree that aircraft in the future will be even a more terrible engine of war than it has been in this war.

The development of armor plate of light type for aircraft has given us during the war steel very much ahead of anything we had before. Some of the armor plate we sent abroad was just as good as that made by the French. It was good enough for the job, and we had a good steel to protect our men.

Equipment of airplanes includes specialized types of machine guns. They have actually speeded up in a practical way some machine guns to fire 12 shots a second, very much more than we thought possible before this war started. They control the gun by a mechanism making it possible to shoot through the propeller without hitting the blades, although this is revolving at a very high speed. Even a small portion shot out of a propeller blade is enough to unbalance the propeller and set up vibration that will tear the whole engine and the plane apart very quickly. 
I brought along a few slides, and I think if we could see them now it would help me in my talk. It would be of far more interest to you. [NoTE.-At this point the speaker exhibited a number of interesting lantern slides showing a large variety of ordnance equipment, including various models of heavy guns, machine guns, projectiles, grenades, etc. He pointed out the salient features of each type and explained briefly their advantages and disadvantages and the part played by them in the winning of the war. The speaker then continued.]

I will conclude with a few remarks which may be of interest, just a few suggestions on production. In the matter of small-arms ammunition during the war and up to November 11 of last year we produced only about 10 per cent less small-arms ammunition than did England and considerably more than the French. In round numbers, our production was $2,864,960,000$; but that is only part of the tale. The rate of increase in production exceeded England greatly, and was even more greatly in excess of that of France. In other words, we built up a machine which was greater than either of theirs. We had a number of very large powder plants. One of these, which was not the largest just before the armistice, produced a million rounds a day of smokeless powder, eniployed over 30,000 people, covered 4,700 acres of land, and used about 100,000,000 gallons of water a day, more than the city of Buffalo, as a matter of fact.

At the time of the armistice we had machine guns enough for $7,000,000$ men, and after July of last year, we had over there more than they could use, including the prospect of replacement. Of shoulder rifles we even further overtopped the average of the British and French. We got into production early with the help of the Enfield rifle, and made during those 19 months about 2,500,000. England produced a little short of $2,000,000$; France about one and onethird million, and they were all of them getting out full capacity.

Our artillery ammunition was slower coming into production, and we have been criticized for this, but this criticism did not take into account all of the factors of the proposition. I can say briefly that we established a production machine which came into operation before it was needed, taking into consideration that we had the use of French and English reserves. Our machine got into production sufficiently in every way in time to avoid the depletion of these reserves, notwithstanding that the artillery was perhaps the slowest of all. I have no doubt that Germany sized up the program as a whole, and that this was the main reason they asked for an armistice.

I may say, in conclusion, that the Ordnance Department started ont with 92 officers and 750 men. We wound up at the time of the armistice with 5,900 officers and 64,000 enlisted men. That is an increase of 830 per cent right there, and that was only a small proportion of the Ordnance Department. The Ordnance Department, in fact, was that portion of the organized manufacturing ability of this country which was producing munitions, and the largest proportion of it was diverted to such purposes. The development of that immense machine is more to the credit of the construction business and professional men of this country than any other one thing. On account of their individual effort and the high class of their intelligence they put through these things without the need of a highly 
compact organization. It is ccrtainly a credit to the thinking and business portion of our country. If any class of men saved our country it mas these same men, who saw the thing in its substantial way and carried through an apparently impossible project.

I ought also to say that the work of the department has not finished by any means with the cessation of hostilities. We have a big job ahead of us, and that is to create some kind of foundation upon which we can build in time of war. That was attempted by this handful of 92 before the war. They did the best they could with very limited facilities. If they had had greater facilities, we would have gotten into production earlier. It certainly would have shortened the war. The necessity of preparation and experimental research work in determining what is the best material and the best way to produce it in quantities needed: these are the factors of the problem I have been trying to lay before you. It is by this that we will avert future wars, and I make a plea for the active assistance of all of you. I have tried to impress upon you that we want your active cooperation and sympathy, and it is as much your job to determine the ordnance policy in the future as it is ours. I thank you.

\section{ADDRESS IN IVEMORY OF IMR. JOHN C. CONNORS.}

Mr. Tighe. Mr. Chairman, I rise to a point of special privilege.

Mr. President and gentlemen, it is with profound solrow that I rise to pay a tribute to the memory of a man whom it was my great pleasure to call my friend, a man whom you all knew in life and one whom you all cherished as your friend. Intelligence, integrity, courage, and unflinching faith were the pillars that held aloft the rharacter of this man. His untiring efforts contributed in a great measure to the success of the National Conference of Weights and Measures officials in former years.

He thoroughly understood the subject of weights and measures, and by the power and energy of his efforts he quickly attracted the attention of the technical minds of the Bureau of Standards. As a member of the committee on tolerances of the national conference, he gave to it the fruits of a practical knowledge second to none in these United States. The laws that thundered down from Sinai were graven upon his soul, and proudly and gladly he took up his cross and by night and by day preached weights and measures.

His ship of life was sweeping gracefully along the rippling sea, the eager winds were kissing every sail, the Port of the Shadow seemed far away, when suddenly and without warning the submerged rock drew near and like a flash the billows roared above the sunken ship. His hour had come, and, alas! the night came down and as he lived he died.

He left us in his golden prime, as manhood's morning brightened into noon. He lives beyond the twilight-purpled hills in the vast region of silence, but he has left behind him a wealth of good deeds done, and in the hearts and memory of men who knew him best his grave is ever green, his memory secure, and his name indelibly enshrined upon the foundation of honest weights and measures.

Were every one for whom he did some loving kindness to bring one hlossom to his grave, he would sleep to-day beneath a wilderness of flowers. 
Few men cherished a closer friendship for this man than the speaker, who a few short years ago suffered a serious illness and was confined in a hospital on the outskirts of Brooklyn. Out of that illness grew a friendship that ripened into love and affection. No more devoted visitor came to my bedside, and always with a token of affection and words of encouragement to relieve my anxiety at a time when it was problematical whether I would live or die.

When one is hovering upon the brink of the great divide, over which all go and none return, it is at least some compensation for the pain and suffering endured to realize that one is surrounded by-

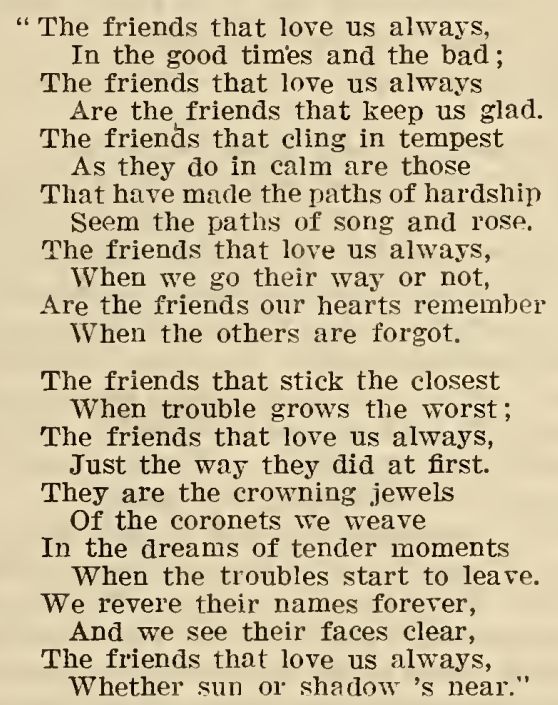

Such was the sterling quality of the friendship of our absent brother, and I move you, sir, Mr. President, that all business before this session be suspended and that we adjourn as a mark of respect to the memory of Mr. John C. Connors, and may the Almighty God have mercy upon his soul!

I move to adjourn.

The Acting Champan. Before I put that motion, I would like to thank Col. Gatewood, and in doing so I am sure I voice the sentiments of the other members of this conference, for the very interesting talk he has given us this afternoon. I am sure we all ought to be interested in what the Army has done, and is doing, to protect us in the future.

Mr. Fine. In amendment of that motion, I would move you, sir, that we stand silent for one minute in the memory of John C. Connors.

The Acting Chairman. Do you accept that as an amendment?

(The motion as amended was seconded.)

(The motion as amended was agreed to and the members of the conference stood in silence for one minute in respect for the memory of Mr. John C. Connors.)

The Acting Chairman. I wish to announce a change in our program. Instead of having the demonstration test of a track scale at 
this time it will be postponed until Saturday. If it is your wish, I will now go on with the regular program.

Mr. Tlgme. Mr. Chairman, I asked that all business before us this session be suspended.

The Acting Chairman. I understood this was a substitute.

Mr. TiGHE. I did not understand it as such. I thought that was an added part of the motion.

Mr. Webster. Mr. Chairman, I believe that if Mr. Connors was present here he would say that we should go on with our program. He felt the importance of this work very keenly, and I am sure that he would want us to devote our time here to the work.

Mr. GregG. As a substitute for the motion, may I move you, sir, that when we adjourn we adjourn out of respect to the deceased brother.

The Acring Chamrinan. Is that accepted by you?

Mr. Tigne. No, sir; unless we adjourn as a mark of respect as I suggested, it is a mere proposition of necessity. We are about to partake of our dinner, and this is only an expression of mine, personal to myself. If it does not fit the views or the feeling of the other's, why they are here to object to it. 'This is a personal expression of mine, having known Mr. Connors for several years and known what he has done in the weights and measures work and what he has done for weights and measures officials. Of course, what disposition is made with that suggestion of mine lies with the members. I have served my purpose in reading my paper.

Mr. Goodwin. If I may add a word, I feel that we ought to adjourn this meeting to carry out this resolution. When I first took hold of the subject Mr. Connors was practically my educator, I might say. He came to me unsolicited, at his own expense, and gave me all the necessary knowledge I neerled in the discharge of my duties. I feel that the memory of a man who has done so much in the interest of the weights and measures laws in this country, I might say in every State in this country, ought to be respected.

The Acting Chairman. Are there any further remarks? If not, those in favor of the motion to adjourn as a mark of respect to the memory of Mr. Connors will say "Aye"; contrary minded "No."

(The motion was agreed to.)

(Thereupon at $4.30 \mathrm{p}$. m., the conference adjourned to meet at 10 o'clock a. m., Friday, May 23, 1919.) 


\section{FIFTH SESSION (MORNING OF FRIDAY, MAY 23, 1919).}

The conference reassembled at 10 o'clock a. m., the secretary, Mr. L. A. Fischer, presiding as chairman.

RECENT DEVELOPMENTS IN SPECIFICATIONS FOR RAILROADTRACK SCALES, BY C. A. BRIGGS, BUREAU OF STANDARDS.

Mr. Chairman and gentlemen, at the time the United States entered the war railroad-track scales had passed through about five or six years of very active development. This has been rendered necessary by the fact that there had been very great progress in raitroad equipment in the United States, particularly as to the size and weight of rolling stock, which had increased to an extent that was not thought possible a few years previons. During this time the science and art of constructing railroad-track scales remained stationary until the discrepancy between what was required for properly weighing cars and what was being generally furnished was very great.

At this time the subject received the attention of the Bureau of Standards, railroads, States, industries, and scale manufacturers, with the result that there was a rapid development in the design and construction of scales, and specifications covering track scales made their appearance from different sources.

Progress is never abrupt, so that radical changes necessary in the construction of scales and the elimination of many imperfect principles were required to be done in stages. Unfortunately it was not very difficult for any trained engineer to study the construction of railroad-track scales and discover what appeared to be a structural defect or an incorrect principle. This, of course, brought into question the other provision of the specifications, and there resulted a general tendency for the engineer to plow up the whole subject and draw up specifications complete on his own account.

At the time of the war, therefore, there were adopted or proposed a rather large number of specifications for railroad-track scales. Among these may be mentioned of special interest those of the American Railway Association, State of Minnesota, American Railway Engineering Association, and the Bureau of Standards.

In meeting the various specifications of their cnstomers the scale companies had been producing a variety of scales, a large number of which differed in no essential particulars, but which at the same time required differences in patterns, drawings, etc., which added very much to the expense of construction.

After the declaration of war the Bureau of Standards, which was on the point of issuing a revised set of specifications, had to drop this matter to a large extent and give its energies to matters which had immediate bearing on the war. The war, however, soon increased the importance of scales, and it was not possible to let the subject rest, and those concerned with the administrative features of the subject continued on the matter of specifications ac- 
cording to circumstances. The State of Minnesota issued a rather complete set of specifications to govern the installation of scales in that State, effective December 1, 1918, in accordance with their previous program.

As the war continued the need for men and material became one of the most important considerations affecting everything. The scale manufacturers found not only that they were having difficulty in meeting their own needs, but were required by the Government to limit their output to a certain percentage of what it had been in previous years, and restrictions on their fuel and cast iron were still further narrowed over what they had been during the previous winter when the fuel shortage first caused restrictions to be imposed

The scale manufacturers undertook to study the matter so as to do as rrell as possible under the circumstances, and one of the first matters evident to all was that a great saving would be effected in the men and material used and in the spare parts required to be carried in stock if there could be a reduction in the number of types of scales manufactured. However. the restrictions were so great that not only was it necessary to cut out types which were to a large extent in the nature of a duplication, but also many which would ordinarily be regarded as necessary. In this connection the new specifications proposed by the State of Minnesota gave them some concern, as they represented just the opposite of what was called for in the restrictions being placed on scale manufacturing.

In connection with the consideration of this problem the writer was asked to address the Scale Manufacturers' Association on the subject of "War-time Standardization of Railroad Track Scales." This request was granted by the Bureau, and on September 10, 1918, the subject of track scales was discussed and the paper given. At this meeting it appeared that the manufacturers were in general accord with what the Bureau had to suggest. In the paper it was suggested that the elimination of the nonessential should consist not merely in cutting out types, but that possibly the needs might be met by something in the nature of more constructive action. It was suggested that it was desired to avoid as much as possible slipping back into the conditions found so unsatisfactory throughout the country in the past.

In previous work the Bureau of Standards has prepared its specifications in careful reference to making the provisions general, so as not to restrict the introduction of improvements, and so as to make the designs as flexible as possible. It was felt in the emergency, however, that what was required was a contrary policy, and the Bureau of Standards was willing to do what it could to help to settle on a few types consistent with the needs. The Government's interest in the scales over which revenues were collected was considered, as, on account of taking over the railroads, the Government had an enhanced interest in the correctness of the scales. The situation was analyzed into the following parts:

The Goverument has a peculiar interest in the accuracy of railroad track scales.

Numerous designs for scales are on the market arising from the natural activities of competition and several sets of specifications from different sources are in existence. 
There is a need for limiting the number of designs to those which are essential.

The designs available have suffered on account of the conditions which have been outlined.

The following suggestions were made for dealing with the situation:

1. That a number of standard railroad track scales not to exceed six should be established representing all possible combinations of lengths and capacities, and that except for very unusual cases all demands for new scales be met by selecting one of these types.

2. That in so far as is practical the scales should be selected in accordance with proper specifications. These specifications should be based on sound engineering principles in order to make them as permanent as possible.

3. That in the accepted types produced by any given manufacturer the details for that manufacturer should be fixed and not changed unless the change is incorporated in all subsequent scales produced by him.

It was stated by a member of the Scale Manufacturers' Association that the paper anticipated practically all the points which were in mind for discussion and that harmony of the ideas was indicated.

Therefore, the most important question remaining to be considered was that of the specifications for the State of Minnesota, which were scheduled to go into effect December 1, 1918. After a discussion it was decided that the manufacturers would formulate in detail the suggestions they would like to make in regard to the Minnesota specifications.

Following the meeting this was made a subject for discussion by correspondence between those concerned in the matter. However the matter did not proceed rery far before another factor had to be considered.

The Minnesota specifications were of interest to the railroads operating in the State of Minnesota, and on account of the policy of the railroads of eliminating, in so far as possible, the unessential they were concerned with any changes they might have to make in their scales during the emergency. As a result Mr. R. M. Aishton, regional director of the Northwest called a meeting at his office in Chicago in October, 1918, for the purpose of considering the specifications of the State of Minnesota. There were present at the meeting representatives from the State of Minnesota, Bureau of Standards, and various railroads and railroad organizations. At this meeting Mr. Aishton stated that he desired to ask as a war measure that the State of Minnesota postpone the date at which their specifications went into effect. He stated that he did not wish to criticize the Minnesota specifications and did not want his present action so construed, but that he was asking that they be postponed in compliance with the need of aiding the railroads to devote all their facilities to expediting the movement of troops and materials.

Judge Ira B. Mills, chairman of the Minnesota Railroad and Warehouse Commission, who was present at the meeting, then stated that the State of Minnesota was willing to comply with his request and that the date at which these specifications would go into effect would be postponed.

Mr. Aishton then stated that he realized that scales were in many instances not what they should be and that he had no defense of railroad track scales as they were in the past. He stated further that the Government had an interest in the scales to a greater extent 
than had been the case and that in the future the Government would have to be considered more of a factor in the scale situation than had formerly been the case. He said that they would naturally look to the Bureau of Standards for a proper scale.

Mr. Aishton emphasized the value of standardization and then mentioned the difficulties which had formerly been experienced on account of the numerous interests inrolved and the personal ideas of the engineers of the railroads in an attempt to standardize freight cars. This resulted in a failure to get together. Since the Gorernment took charge of the matter, however, it had been possible to obtain a standardization, with the consequent benefits. He was of the opinion that, haring in mind that it was a United States proposition and that what was wanted was progress and economy, adrantage should be taken of the presence of the rarious parties interested by proceeding with the subject of what should be incorporated in specifications for scales which could be applied after the war. It would, then, be his purpose to submit the findings to the Director General for general adoption to secure proper weighing scales of uniform type.

As a result a committee was formed on which there were representatives of the following organizations: The Minnesota Railroad and Warehouse Commission, the Scale Manufacturers' Association, the National Scale Men's Association, and the Bureau of Standards. Members of the American Railway Association and of the American Railway Engineering Association were also on the committee and unofficially represented these associations.

This committee has since become known as the Aishton Committee. At the first meeting it was apparent that the members of the committee representing verv different interests were much in the mood for getting together. There ensued sereral meetings from which resulted the most complete set of specifications thus far prepared, upon which all the members of the committee were in rery substantial accord and which were indorsed by all of them. It was intended originally to have represented on this committee delegates from the American Railway Engineering Association and the American Railway Association, but this arrangement was not completed in time. Howerer, the specifications hare now been indorsed by the American Railway Association and practically so by the American Railway Engineering Association. The latter body, howerer, have certain changes which they have suggested and which they may propose to the Aishton Committee for adoption. with the probability that they will be accepted by that committee. There is, therefore, a possibility of having, at an early date, rather complete specifications for railroad track scales in which all interested are in accord.

This same subject was of interest. howerer, in connection with the Interstate Commerce Commission docket No. 9009 on loss and damage claims for grain in bulk shipments. The matter of the weighing of grain had been found to be one of the main issues. After an unsuccessful attempt to get the carriers and shippers together, Commissioner Clark, of the Interstate Commerce Commission, prepared a letter which he sent to Mr. F. C. Maegly as representing the railroads, and $\mathbf{M r}$. H. L. Goeman, as representing the shippers. Since 
this outlines the situation it will be read though it lengthens this paper considerably:

I am advised that the joint conference of the committees representing the grain interests and the carriers held at Chicago on April 16 and 17, 1918, pursuant to our report in "Claims for loss and damage of grain, No. 9009," adjourned without reaching an agreement or arranging for future action upon the matter of grain claims.

It was shown in this investigation that there is urgent need of improvemen in the facilities used and the practices followed in connection with the transportation of grain in order that losses in transit may be reduced; that more accurate and complete records may be obtained; that improper claims may be eliminated; and that prompt and fair settlement of just claims may be brought about.

The carriers and shipper's being directiy interested and also fully advised as to all phases of the situation, we suggested in our report that they should confer and agree upon what rules and practices would be just and reasonable. It was thought that the subject could thus be dealt with in a more satisfactory and comprehensive way than if the commission should undertake to prescribe rules respecting only such matters as are within its jurisdiction.

The failure of the conferees to formulate rules or to provide for any further joint action appears to have been largely due to insistence that as a primary matter a rule should be agreed upon limiting legal rights and liabilities pertaining to the adjustment of claims on so-called clear-record cars. Without criticising the attitude taken in that respect or underestimating the importance of this matter under present conditions, I venture to suggest that rules intended to limit the legal rights of either party should not have been presented, because they would not be bincling upon the carriers and shippers as a whole and are beyond tle jurisdiction of the commission to prescribe.

It seems quite probable, however, that if fair rules should be adopted dealing with the practical aspects of the situation, such as the installation, operation, and maintenance of scales, the inspection and supervision of elevator equipment and records, the condition, inspection, and cooperating of cars of origin, specifications for grain doors and the installation thereof, the weights and weighing of grain at origin and destination, the inspection of cars and the recording of losses or other defects noted in transit and at destination, allowances on account of scale variations, natural shrinkage and waste and the filing and investigation of claims, including the adoption of a standard form for the presentation of grain claims, and providing for an impartial audit or supervision of claim investigations and adjustments, the existng sources of controversy would be largely diminished, and, therefore, relatively few claims would arise which could not be satisfactorily adjusted without resort to litigation.

Before proceeding further in the matter I wish to suggest for the consideration of the respective committees the propriety and desirability of appointing a small joint working committee to formulate and submit a complete code of rules to be considered and acted upon by a joint conference of the carriers and grain interests and, if necessary, by the commission. It is believed that if the various matters in issue are considered in a spirit of fairness and any attempt to abridge the substantial and well-established legal rights of either party is abandoned there should be little difficulty in harmonizing the difference or opinion that may develop.

As a result the shipper's and carriers again undertook to find a settlement of the question. Under the Pomerene law the railroads were required to accept bills of lading of the carrier's on the shippers' weights when the grain had been weighed by adequate weighing facilities. It was soon apparent that what was termed adequate weighing facilities would have to be defined by specifications. As i result, there was formed a committee on specifications on scales for weighing grain, consisting of the following member's:

Mr. J. A. Schmitz, weighmaster's department, Chicago Board of Trade, chairman; Mr. George Betzelberger, Illinois Grain Dealers' Association; Mr. C. A. Briggs, Bureau of. Standards, Washington, D. C.; Mr. W. P. Buchan, Richardson Scale Co.; Mr. C. A. Redfield, 
scale department of the Minnesota Railroad and Warehouse Commission. This committee was concerned with hopper scales, automatic scales, and railroad track scales over which grain was weighed.

In the deliberations of the Aishton Committee it had been decided that railroad track scales used for weighing grain were not within the province of its work, as such scales usually belonged to private or industrial concerns over which the railroads had no direct control. Moreover, railroad track scales for weighing grain were not necessarily subject to the same requirements as the scales considered by the Aishton Committee. The grain scale committee, however, desired to cooperate to the fullest extent possible with the Aishton Committee, as it was appreciated that uniformity in the specifications would be a great assistance in getting proper scales installed. As a result the specifications rere prepared in so far as possible in compliance with those of the Aishton Committee.

At the last meeting of this committee held in Washington during March. the Aishton Committee had completed its specifications, and at the request of Mr. Goeman, who had been elected chairman of the joint committee of shippers and carriers, the precise rording of the Aishton Committee was employed when the provisions were in substantial agreement. This was carried out to the fullest extent possible. It was necessary, however, to have certain provisions different on account of the special requirements for weighing grain. These differences, however, are not inconsistent. There is, therefore, substantial agreement between the specifications of the Aishton Committee and those of the grain-reighing committee.

We may say, therefore, that there is now in existence a set of specifications for railroad track scales which have received the most thorough consideration and which will probably represent the standard for railroad track scales in this country for some time to come.

The Actixg Chatriran. The next on the program is a paper entitled "The Metric System," by Mr. F. A. Halsey.

Mr. McGradr. I would like to make a motion that some of the papers be presented to the stenographer and printed with the report.

The Activg Chairmax. I will say in response to this that these gentlemen have been asked to appear on this program, and it would be a scant courtesy not to proceed. Howerer, in so far as the papers referred to are by members of the Bureau, this course will be followed, if desired.

Mr. McGRady. With the reading of these papers we are consuming so much time that really we who are doing the practical weights and measures rork are getting no results. We have nothing to bring back except the papers a year from now. I have not found out a thing of any benefit to me in Pittsburgh.

THE METRIC SYSTEM, BY F. A. HALSEY, AMERICAN INSTITUTE OF WEIGHTS AND MEASURES.

When, 15 or 18 years ago, Mr. Dale and I published the results of our inrestigations showing that the claim for the universal use of the metric system, except in the United States and Great Britain, 
was unfounded, that in most so-called metric countries it was nothing more than an official system used but little by the people, our statement of facts were received with shouts of derision.

We said then what we now reassert, tlat the metric claim had nothing behind it but initial assumption, followed by endless repetition, where in it stands upon the same footing as the story of George Washington and the cherry tree. Both are widely believed because of endless repetition, but neither is founded upon fact and neither is true.

These shouts of derision over our discoveries have now ceased, and I am here to point out to you not only this fact, but also the remarkable extent to which our findings have been confirmed.

Most of you have, I think, received my report on the metric system in Latin America, while for those wlo liave not received it I have copies here for distribution, together with copies of a more recent pamphlet, "The Metric System Condemned by Those Who Know."

Prior to the publication of this report, Latin America like many other countries, had been claimed to be "purely metric;" "they had forgotten their old units;" "our units are meaningless to them;" "we must deal with them in language they understand," etc.

This investigation shows that with a single exception (Uruguay) the metric system in Latin America is a joke. Because of laws which are fairly grotesque in their severity, the metric system is in common use in domestic trade and commerce in Uruguay, although even there the laws are not entirely effective. In no country of Latin America is the system universal; in most of thens, except in Government transactions, it is used but little; in 10 of them it can scarcely be found in the practice of the people; and in five of them the English units are used far more than the metric.

These are my findings, and in connection with them you should remember that those countries adopted the metric systen! more than half a century ago, most of them having gone into it like a flock of sheep between 1850 and 1860 .

Next, I wish to place before you some confirmations of these findings. Some years ago-that is, before the war- our Department, of Commerce sent $\mathrm{Mr}$. W. Graliam Clark as a special agent to Latin America to investigate the conditions and trarle opportunities for the sale there of the products of our textile mills. Mr. Clark spent several years in personal investigations upon the ground. He went to Latin America in order to detelmine what we should do to gain the trade of those countries, and in not one of his reports is there so much as a word regarding the adoption of the metric system. Moreover, he names the system of measurements used in nine of the countries which he visited, and in every case he confirms our findings.

Since my report was published, a book, "Getting Together with Latin America," has appeared from the pen of Mr. A. Hyatt Verrill and from the press of E. P. Dutton \& Co. Mr. Verrill has lived for many years in Latin American countries, and, upon his return to this country, he prepared this book in order to place before our exporters the things they should do in order to sell goods to Latin America, and, like Mr. Clark, he does not even mention the adoption of the $155530-20-8$ 
metric system. Nearly half of his book is given up to an appendix in which is given statistical and other detailed information regarding the various countries, which are arranged in alphabetical order. For 18 countries he names the system of weights and measures used, and he confirms my findings in every case except one.

Unknown to me, until the results were placed in my hands, Mr. Henry R. Towne, president of the Yale \& Towne Manufacturing Co., sent a questionnaire to the branches and representatives of that company in various parts of the world, and the answers to that questionnaire confirm our findings in every instance.

In 1913, Mr. F. S. Holbrook, of the Bureau of Standards, went to Porto Rico to assist in preparing for the enforcement of weights and measures legislation passed shortly before that time. His report which was published as part of the proceedings of a former session of this conference absolutely confirms my findings for Porto Rico.

In the New York Herald for April 6 is given an interview with Mr. William C. IVells, chief statistician of the Pan American Union, from which the following are extracts:

Everyone recognizes that there is a connection in the matter of measure be1 ween our dounestic mauufacture and the export trade, more or less direct, but it is much less direct than is ordinarily believed. Sometimes the measure counts; sometimes it does not.

The problem, however, is different when you come to consirler the extent to which English measures have penetrated Latin American countries. This extent is much greater than the advocates of the metric measures in the United States are willing to admit.

Where American or English monopoly exists, English measures are received, and it probably would not be wise to change.

This penetration *** is particularly in eviclence in Cuba and Mexico. In Cuba it has extended to a remarkable degree. Eren the Cuban statistical publications show sugar exports in pounds, not kilos.

Quite the most remarkable of these confirmations of our findings is found in Commerce Reports for April 21 under the subhead "Prepared by the Latin American Division of the Bureau of Foreign and Domestic Commerce, With Assistance from the Bureau of Standards." From this article I quote as follows:

Truguay.-This system was adopted in 1862, * * * but it did not come into general use until made compulsory by law in 1894, providing that fines should be imposed for the use of other systems. It was found, linverel. that customers continued to call for articles under the old names.

Argentina. - While the metric system is legal, it is only compulsory in Govelnment departments, and a number of old Spanish measures still survive.

Bolivia.-The old Symisl units, which vary greatly; are in gencral use nutside of Govermment aud litilway circles.

$B r a_{z i t}$ - The Almanach Commercial Frasileiro states that the metric system was adnpted in 1862 and made ohligatory in 1874 , alding, howrere, that. as many of the old nemsules are still lised in the interior of the combtry, tables ot equivalents are given in the Almanach.

('hili.-Many of the country districts still cling to the old units.

Pcru.-The dmerican commerial attarese at Lima reported that Ial comerou "speaks of the lame metric system of Peru." hecausc many articles are nurchased at wholesale by the metric system and retailed by a nother system of reights and mersures.

Tenezuela.-In spite of the stringent laws, old peonic and country people cling to the old units in domestic lite, and this will rinly be clanged by the growing up of a new generation.

When reading these extracts from Commere Rejorts, it should not be forgotten that the seven comutries referred to therein are all 
from the list in which my "Report on the Weights and Measures of Latin America" shows the system to have made the greatest progress. I am very glad to believe that the selections are accidental, but it is nerertheless proper for me to point out that to the 10 countries wherein I have shown the metric system to have made substantially no progress among the people and to the 5 countries in which I have showl the English units to be used far more than the metric, no reference whatever is made.

During the past year I have attended two great foreign-trade conventions-those of the National Foreign Trade Council and of the American Manufacturers' Export Association. At both of these conventions so many papers were offered that it was necessary for them to be held in parallel sessions. At one of them an afternoon session was devoted to education for foreign trade, and in no one of the papers read at that session or at any other session of either convention was the adoption of the metric system for the benefit of export trade so much as mentioned, and it is to be remembered that the papers read at these conventions were prepared by those who are in immediate contact with export trade.

Our findings are thus established and acknowledged. You can no more doubt them than you can doubt the multiplication table, while against them you have nothing but assumptions endlessly repeated.

A graphic summary of our 20 years of investigation has been prepared by Mr. Dale in the accompanying map, which is the only authentic, comprehensive exhibit of the weights and measures situation of the world as it exists to-day that has been prepared by anyone. Whatever you have seen or heard that differs from that map is untrue.

And now comes the World Trade Club of San Francisco with a pamphlet and a map, by which latter we are told that Greenland, Patagonia, and the Sahara Desert are all "metric." The text of the pamphlet also repeats the assertion that "all the civilized world has adopted it except the United States of America and Britannia."

Among the specific statements of this pamphlet I find this:

The large French population of Canada has greatly increased the use of the metric system there.

In reply to this I give yon the following from Mr. E. O. Way, chief inspector of the Canadian Weights and Measmres Inspection Service:

The facts are that the use of the metric system of weights and measures in Canada is practically nil, and less in our Quebec Province than in any other.

Ninety per cent of the San Francisco pamphlet is of a piece with this. That organization has collected all the statements favorable to the metric system they could find and reprinted them. They know nothing about their truthfulness, but, whether true or false, they all make good campaign material.

The question before us is, Why and how has the world gone so far wrong in this matter? The man in the street has merely accepted these endless repetitions and his opinion has no value. There is, however, one class of metric advocates from whom we expect something better-one class to whose opinions we attach some value 
because we expect them to speak from knowledge. I mean, of course, the scientific men who hare gone wrong equally with the man in the street, and it is important to ask and to answer why they have done this. The explanation is a simple one and, while it does them no particular credit, it at least supplies them with a ladder on which they can climb down, and I am glad to supply sucli a ladder, because climb down they must.

The scientific man, like many others, has made the initial assumption that a change in weights and measures by a country may be easily brought about. It seems to me quite clear that this is a matter, not of belief, but of fact; and, while the facts show such a change to be a matter of supreme difficulty, the scientific man has made no investigation of such facts.

He had his initial belief that the change is easy, and in his case this belief was fortified by the fact that in his own work the change is easy. I have said this many times and repeat it now. In the affairs of modern life there are three leading applications of weights and measures to industry, commerce, and science, which applications are named in the order of decreasing difficulty. In industry we have both the universal psychological difficulty of learning to think in metric units and the still greater physical difficulty of a change in manufacturing sizes. In commerce the physical difficulty, while still present, is nevertheless much reduced, although the psychological difficulty remains in full force. In science the physical difficulty nearly disappears, while the psychological difficulty is at its minimum.

Let us compare the task of learning to think in netric units as it appears to the laboratory scientist and the corner grocer. Should this change come to pass, both parties must use the kilogram and learn to visualize values in it, or to think in kilograms as the expression is.

For this the scientist must acquire a clear conception of the ralue of the kilogram, and the psychological task so far as the kilogrann is concerned is then consplete.

The grocer must also acquirc this conception, but his task is then no more than begun. With the grocer, units of weight are compounded with price units. He buys and sells many things of which the prices are given as so many cents per pound and, stored in the back of his heac, is a whole series of such price units, both wholesale and retail, for all the commodities that he sells by weight, this being an important part of his business equipment.

After the metric system is adopted, he must acquire a new sense of price values in cents per kilogram for all of these commodities. If he sells 100 articles by weight, he has 100 times as much of a task before him as the scientist before he has learned to think in kilograms; indeed, I should say 200 times, for the grocer must have in mind both wholesale and retail prices.

It is useless to say that he may divide the price per kilogram by 2.2 in order to reduce those prices to cents per pound, because so long as he has to do that he has not learned the metric system, for he still thinks in pounds.

After the grocer has acquired this new sense of price. values, he must then teach his salesmen, buyer, bookkeeper, and others who are 
concerned with prices, and after they have acquired this new sense of price values, the grocer must deal with his customers. Some of these customers are not very intelligent, while some are stupid, so stupid that they are unable to understand why butter at $\$ 1.10$ per kilogram is a better purchase than the same butter at 50 cents per pound. I confess that I am that stupid myself, and I know many others who pass as men of average intelligence in the affairs of life who are just as stupid as I am. Other customers, again, are indifferent and can sce no reason for all this pother for no particular purpose, while still others are hostile and object to recasting all their ideas of values not only for groceries but for everything they buy.

Some of these hostile customers tell the grocer that when he names prices in these strange units they can not tell whether he offers them a bargain or a swindle, and they tell him very plainly that unless he can offer them goods in terms that they understand they will go to other grocers who will.

Were I to compare the task of the scientist with the manufacturer, we would find an even greater difference than that between the scientist and the grocer, but it seems to me that the illustration I have given is sufficient to show that the scientist has no right to speak for the corner grocer.

It seems to me that $I$ have also showed the reason why the scientist believes this change to be easy, because in his field of work he has found it so, and this is the first great lesson I have come here to teach.

The continued use of old units in so-called metric countries being now established and admitted, it is necessary to refer to an old explatnation which recently has been revived-namely, that this practice is a survival of names, but not of things; that in metric countries the people apply the old names to metric units; for example, that in Latin Amelica when they say vara they mean meter and when they say libra they mean half a kilogram.

It should be noted at the start that this explanation is always limited to units of the two systems which do not differ greatly in value. We are never told to what metric units the Spanish names "pulgada" (inch) and "pie" (foot) apply.

The replies to the questionnaire which was distributed throughout Latin America are sprinkled with such expressions as these: "Metric system infrequently;" "The two standards are used indiscriminately;" "The meter is used very little;" "The artisans of the courtry use in their calculation the Spanish vara as their standard;" "Our standard of weight is the quintal of 100 Spanish pounds;" "The people continue to use the old Spanish measures;" "At retail vara, at wholesale yard, meter;" "While the metric system is legal, it is not enforced;" "In domestic business only the Spanish system it is not enforced;" "In domestic business only the Spanish system is still commonly used, but is prohibited in the documents;" "The old Brazilian system is still commonly used;" "Cloths are sold indiscriminately by meters, varas, and yards;" "Occasionally the metric ton;" "The metric measurements are sometimes used."

Such expressions as the above, of which there are many more, can not be thus explained.

Many of the replies give values of the Spanish in terms of metric and English units, which show that the old names are not used for 
the new units. Of these a few of many examples follow (note that the libra is not a half kilogram):

From Costa Rica: Vara, 0.836 meter ; libra, 460 grams ; cuartillo, 4.165 liters; botella, 0.67 liter; manzana, 6,988 square meters.

From Argentina : Vara, 0.866 meter; pie, 0.289 meter; libra, 0.4594 kilogram; tonelada, 918.8 kilograms.

From Nicaragua: Vara, 33 inches ; libra, 16 onzas ; fanega, 288 libras; manzana, 10,000 square varas.

From Ecuador: Vara, 84 centimeters; libra, 16 onzas; cuadra, 100 square varas.

From Guatemala : Vara, 2.78 feet; manzana, 10,000 square varas; cabaleria, 64 manzanas; cuadra, 625 square varas.

From Mexico: Vara, 2.7 feet; onza, 1.0148 ounces avoirdupois; cuartillo, 1.7 quarts; sitio, 1,755 hectares ; caballeria, 42 hectares.

From Venezuela: Vara, 0.836 meter; pie, 0.279 meter; pulgada, 0.023 meter; libra, 400 grams ; arroba, 11.5 kilograms.

From Honduras: Vara, "about 33 inches;" manzana, "100 square English yards."

From Brazil: Libra, 0.45905 kilogram; arroba, 14.6896 kilograms; oitava, 3.586 grams; quartillo, 0.665 liter; canada, 2.662 liters.

From Peru: Vara, 83 centimeters; topo, 5,000 square veras, or 3,485 square meters; quintal, 46 kilograms; marco, 228 grams.

From Chile: Quintal, 46 kilograms; arroba, $11 \frac{1}{2}$ kilograms; corcada (cord for firewood ), 6 pies by 3 pies by 3 pies.

More might be given to the point of weariness, but the above are sufficient. Not one of all of these hundreds of sheets contains a single item to substantiate this explanation. No proof of it has ever been offered. It is clearly untenable and must be dismissed.

As it is now demonstrated and accepted that the "adoption" of the metric system in Latin America has led to nothing but a mixed system of units, I desire, next, to point out the consequences of this mixture.

In Latin America, the butchers buy beef cattle on the hoof by the kilogram and they sell the beef from those cattle at retail by the libra. Similarly, the dry goods merchants buy their fabrics at wholesale by the meter or yard, in accordance with the country of their origin, and sell them by the vara, while the customhouse duties are assessed by the meter. This condition is very common in Latin America, although the units used are more often inverted from those named. The metric system has made much greater progress in retail than in wholesale markets, the result being that merchants everywhere buy their goods at wholesale by one system and sell them at retail by another. You will observe from this how simple their calculations must be.

If you lived in that part of the world and had occasion to erect a building, your building lot would be measured by the vara; while the mansonry work would be done by the meter, the carpenter work by the pulgada, the painting by the square meter, the glazing by the inch, and the piping by the meter for length and the inch for diameter, and when your builder went to the lumberyard to buy his lumber he would buy so many cubic meters of 1 -inch boards. You will recognize at once how simple his calculations must be-how simple when he calculates the cubic meters of 1 -inch boards required by the floors, how simple when he calculates the cubic meters of 10 by 12 inch timbers required for the frame, and when he determines the velocity of water in meters per second and the dis- 
charge in liters through a 2 -inch pipe his calculations will be so simple that he will make them with his eyes shut.

I am telling you what that builder does because his country has adopted the metric system, and I am telling you what we will do should our country adopt the metric system.

As the scientist has found nothing so easy as to introduce a new unit of measure, so the world has found nothing is so difficult as to get rid of an old one.

Does it not occur to you that the time has come to stop chasing rainbows? Is it not clear that we must compare what we have with what we will get, not with what the metric party piously hope we will get?

Shall we learn from the experience of others, or shall we plunge headlong into this bottomless morass? Shall we join the chase of this will-'o-the-wisp which the nations are always chasing, but never catching, and which leads nowhere but into a quagmire of confusion and disorder?

In conclusion, I desire to express my appreciation of the courtesy of Dr. Stratton in permitting me to address you. His action contrasts most favorably with that of Mr. Fred R. Drake, chairman of the metric-system committee of the National Wholesale Grocers' Association, who has positively refused to permit these facts to be placed before that association. You will recognize at once the means by which the wholesale grocers have been led to indorse the adoption of the metric system.

DISCUSSION OF ABOVE PAPER.

Mr. Weuss. Do I understand that in Uruguay the lumbermen cut their lumber by the inch or foot?

Mr. Halsey. The inch is my understanding. They sell it by the meter. You buy so many cubic meters, or so many square meters.

Mr. Welus. What does the lumberman use?

Mr. Halsey. Lumber is cut by the inch. It is in my report. You will find it in my report.

Mr. Weurs. My only interest is that in Uruguay there is no lumber cut. Uruguay is not a lumber-producing country.

Mr. Halsey. I am talking about lumber used. I do not know whether they have sawmills there or not.

The Acting Chamman. Members and guests of the convention, we have with us Secretary Redfield, who has been kind enough to address us continuously ever since he has been in office. I do not think that Secretary Redfield needs any introduction.

ADDRESS BY HON. WILLIAM C. REDFIELD, SECRETARY OF COMMERCE.

Mr. Fischer and gentlemen, I am sorry that a word of welcome from me was delayed so long. I can only plead that I was absent from the city on necessary public business, and I am fortunate in being able to crowd into this hour with you between the necessities of daily work, as I hare to leave this afternoon for another brief absence on public business. 
It is a pleasure to have you back again under peaceful circumstances. I remember that when you were last here the clouds of war were all about. We could not then foresee what was to happen in the two years that followed, and now we have seen such a sight as I suppose the nations of the world have never seen before. Yesterday a representative of a foreign government asked me if I supposed there had ever been such a complete collapse of a great power as we have witnessed in the last six months. I presume there has never been anything like it. We look back to the times of the old military empires and thought instinctively reverts to the great imperial power of Rome covering the world. Her decline and fall, however, took several centuries to bring about, and even after she went her name was preserved.

It has been only a few short months since the German terror passed away, and I believe that we in this country now do not realize yet what it means to many of our fellow men to have that German terror gone. I suppose the Hollander, the Swede, the Norwegian, and the Czechoslovak feel as if they had come out of darkness into light, out of danger into safety, out of a condition in which threats were hanging over their heads all the time into a world where for the first time they know security. Our papers are full of talk and countertalk, the superficial current gossip; but I have no fear whatever, gentlemen, that any of these shallow opinions asserting that there will be no signature to the treaty of peace have any possible significance. I think that if we were permitted to see the condition into which hideous selfishness has brought Germany, the condition of starvation, not merely of food, but of all the ordinary supplies of civilization, we would realize that the pressure of the blockade upon them has been such that for the mere means of industrial existence, for clothing, and shoes, and all the necessary things of life they must needs come very speedily into peace with the world at large. My own feeling is that they will have to bear the greatest suffering that can be imposed upon a high-spirited people when after peace is established they go out, now and then, into the great world with the thought of resuming a place in it only to find what the conscience of the world has personally and privately to say. I think that then, and hardly until then, will this people which has striven to overwhelm the world, and has itself been overwhelmed, realize what the common judgment of mankind is as to what they are and what they do.

The vision of the national selfishness which has come to a national tragedy brings us back naturally to what the American outlook is to be in the world. We stand now at the parting of the ways for our country, as Germany not long ago stood at the parting of the ways for hers. Our very wealth and prosperity create for us a very serious problem. I said that in dictation not long ago, and my stenographer interrupted me to ask how wealth and prosperity could bring with it very anxious and difficult problems. Let me outline my explanation. The world owes us about twelve billion dollars, and in some way or other will pay it. The world is hungry to a degree which we have never realized. We are sending more food abroad than we supposed we should ever be called upon to send, so much that our exports of all goods last month ran up to something more than seven hundred million dollars, and the balance in our favor 
for last month of over four hundred million dollars represented an annual rate of five billion dollars, accumulating, observe, on top of the twelve billion dollars of loans. If, in addition to that, we are to do our normal foreign business, how is the world to pay? We are in the position, you see, of a great creditor who must needs continue selling to keep his industries and his farms at work. We are growing more wheat than we are using, and we must sell it; producing more goods than we can use-we must sell them; and we must buy some things abroad and must export to pay for them. But how is this great debt to us to be paid?

The nations of the world are solvent in the sense that they have back of them the resources from which to pay. A man would be foolish that would suggest that the British Empire was not abundantly able in time to meet every obligation, or that France, with her wonderful thrift, the most saving people in the world, with her great African empire behind her, was not abundantly able after a while to pay, and that Italy in the same way would not be able to pay. All of these things we know, and yet debts can be paid in only three ways. They can be paid only in cash or in credit, which is a deferred form of cash, in goods or in services. The foreign nations have not the cash, they have not the goods, and if they had we do not need them and they can not render the service they once rendered because we purpose running our own merchant marine and have established our own insurance companies, which are two of the greatest services they rendered us before the war. So, as there are three ways to pay vast obligations, and none of the three ways are satisfactory, and none can be used in sufficient quantity, nor even all three together, the actual problem of our prosperity becomes a very big one indeed. We are in the position, if I put it to you as a private individual, of you owing me a great sum. You have land and lumber and grain, a sufficient amount of money for yourself, and willingness to work. Suppose I say to you, "I do not need your work; your grain and your lumber I do not require; your land I do not want; and you have not sufficient cash." How are you going to pay me? It is obvious that in spite of these conditions, the obligation is on me to be paid, on you to develop your own resources so that they may become liquid as soon as possible in order to get the means of paying me. That is the world problem to-day.

We must be patient with the world and not expect our debtors to pay us too fast, and we must help them pay us and not growl because they may put an embargo here and an embargo there. This action means only that they do not want to buy any more for the time being, so that they can get their affairs settled and pay for what they have already bought. There has been much unnecessary protest against enbargoes, which merely mean, as I have said, that in not buying for the present they may pay more readily for past purchases. Besides, gentlemen, we have done something similar in the embargo line. I suppose that the French wine industry has marked views on the subject of the prohibition amendment to the United States Constitution. I am not objecting to the amendment, but I point out that when Americans object to the French embargo they ought to remember that they put an embargo on one of the most important French products without asking France any questions about it, and put it 
on permanently, whereas the French embargo on some of our goods is a matter of a few months. Along with our own protests let us remember the Scotch whisky distiller and his views of the American embargo; the English ale brewer and his views of the embargo. I mention this to show that criticism can not be wholly on one side and that when Great Britain declines temporarily to purchase certain goods from us we must bear in mind that we have declined permanently to purchase certain goods from her, and not get mad and start to grumble.

There are two sides to every question of the kind. There is only one way of solution that I see except patience and time. I know of only one way to solve the big problem that I have suggested to you very simply - this problem of perfectly solvent creditor's owing us enormous sums which we try to increase by selling them more. all the time-and that is that we help them develop in order that we may get back what they owe us.

Fifty years ago the United States did not build its railroads on its utilities out of its own funds, but it borrowed from Amsterdam, and Berlin, and Vienna until when the war began, we owed them over five billions of dollars for building up the United States. Certain great railioads were built with English and Dutch capital. Great corporations in this country issued bonds in pounds sterling and marks, and that is what built us up. Our industries, railroads, and utilities were constructed largely on the basis of foreign capital loaned here for our benefit. That was good for us and for them, and we must do the same thing now in other countries. It is a strange thing to us, wholly novel. We have not done this heretofore, but we have to become lenders ourselves. There is a threefold business advantage in loaning our money to foreign lands. Some think we don't want to, some of us may think it is risky; but it has to be done, for they owe us $\$ 12,000,000,000$, and we have to get paid for it some way. We can help them pay us by developing their wealth. That means that if a city in France needs to develop itself, it will offer its securities for sale in the United States. If a public utility in Italy needs to develop itself, it will offer its securities for sale here. If Madagascar wants to build a railroad, she will come to the United States to hold the bonds. If Denmark or Holland wish to build highways, gas works, or l'ailroad lines, they will come here for the money to do it. That works three ways to our profit. In the first place, we get the interest on the investment, if we do not invest wrongly. In the second place, we get the business that naturally comes from the companies that are thus operated with American cash. In the third place, this increases their wealth, and thus enables them to pay us more readily the money they owe us. In these three ways foreign investments are profitable and I am discussing the subject this morning because it is one of the coming things in this country. We will have to get accustomed to it just as fast as we can, because Bill Jones and the other fellow in Great Britain, France, Serbia, Roumania, Czechoslovakia, and Jugoslavia owe us a great deal of money, and we want to get it back without doing them harm. We will have to play the game with them arm in arm and hand in hand in a way that we never played before. There are just two ways to get along with a debtor: One is to help him, the other is to fight him. You can not ignore him; that you can not do. For that reason, if there were no other reason, you and I 
are tied to the world because we hold their promissory notes bearing interest due us. We have their notes to us, and I am sure that no one of you puts such keen interest in anyone as in the fellow who owes you money. That binds you and him together. The men who suggest that we Americans, now that the war is over, can draw in our horns, stay inside our own 3-mile limit, and go back into our former isolation, forget the $\$ 12,000,000,000$ that must needs be paid. That is the whole story in a nutshell. That is the background for the new relations of the United States. We are in the family of the world, and we can not get out; we are in too deep in investments everywhere. Our wealth is invested all over the world. You all, no doubt, have Liberty bonds and Victory bonds; there is hardly a man here that does not hold them; and against them in the United States Treasury are some six or seven billions of dollars of securities of lands whose names we could not even pronounce two years ago.

We are bound together in this great world, and nowadays we see New York concerned with the prosperity of Buenos Aires and Lima, the interest of Chicago affected by Caracas and Omsk; others of our commercial center may look to Pekin and Shanghai and Tokyo for carrying on their operations. We will never go back. You and I have been, in a national sense, boys in school and the end of the old school term has come, and we have graduated out into life. We are no longer playing a local, provincial, narrow game. The game is as broad as humanity and as large as the planet, and we can not help it. We may be just as reluctant as we choose, but the only way in which we could get back would be in some inconceivable way to get the $\$ 12,000,000,000$ paid. Besides, we know now that when little Belgium stood up to the mighty power of Germany she was fighting our fight. We are certain of that now. We are not admirers of kings, but there is not a man of you who would not show honor to King Albert and to his queen. We know perfectly well that when Serbia fought almost to absolute extinction, losing everything, she was fighting our battle. We know that the small nations of this world are tied to us because we are not quitters. We brought the new Poland into life. We brought the new Czechoslovakia into life, and erery Bohemian and every Moravian knows that America was his foster mother in his new freedom. We brought back Serbia into life, and every Croat and every Slovene and Jugoslav knows that America was his rescurer, restoring him to freedom. Every Dane knows that it is the power of America and her associates that is restoring to the Danish people Schleswig, stolen from them in 1865 . They all know these things, and because they are true and because out of our freedom and wealth and by the sacrifice of our boys and of our means and our food we did bring these nations into life we are not ging to quit the game and say, "There you are; now look out for yourselves."

Gentlemen, in thinking of you and the work you do, I have often reflected that you are the followers of perhaps the oldest code in the world. There were many ancient codes, and we find them in Babylonia marked on slabs and plates of brick, but those codes are dead. The codes of ancient Egypt and the laws of Rome have all passed out of the memory of man, and we hardly know what they are. But the code under which you work, written actually 2,000 years ago in a 
book which Jew and Gentile honor and which Christian and Mohammedan alike respect, that old code still survives, and in it are these words, that the false weight is an abomination to the Lord.

That is your anthority, the charter that was written long before Christ walked in the land of Judea. It was then, and is yet, an abomination to the Lord. I do not know any organization or group of men that has a more authoritative charter than that. That makes it pretty well worth while to have your job to do. The moral judgments of the world are formed pretty slowly, but you represent probably the very oldest of them all, and that, surely, is a fine thing to be connected with.

This war has brought us one thing very valuable, a certain sense of social union that we never had before. My boyhood friend-he was so much younger than I was that I thought of him as a boyTom Whittlesey, up in my old home town in Massachusetts, was a major of the Lost Battalion. Who made up the battalion? The boys from the East Side of New York. Some of us would have been just foolish enough 20 years ago to langh at some of the names of the boys, because they seemed queer, but the 450 men that Maj. Tom Whittlesey commanded in the Lost Battalion were almost all taken by the draft from the East Side of New York, and as you look at the names representing 10 or 12 different nationalities, Americans, every man of them, but with different traditions back of them, you get a sense of the unity of America that you get hardly anywhere else. These men were unanimonsly perfectly willing to die, and they did not back an inch, but stayed where they were. I could give a thousand other instances that is only one-as proofs of the unity we have not had before. It is taking some very surprising forms.

I met on the train two or three weeks ago one of the most conservative men in the country, as I supposed. He was the head of one of the big inanufacturing companies in New England. He was the chairman of the executive committee of another, and a member of the board of directors of a third, steeped up to the ears in the industrial traditions of the capitalist type, and about 65 years of age. All this, I should think, would justify us if we were hasty in classifying him as a mossback. Now, this man said to me in the train that he thought at 65 years of age he had got to the point where, having attended to his personal convenience the most of his life, he ought to do something for his country; so he accepted nomination and election to the Massachusetts State Senate. That man with that background introduced a bill into the State senate which is now the law of that conservative State of Massachusetts, whereby any manufacturing corporation of that State is authorized to have the workmen in its eniploy elect one or more of their own number to be a member of the board of directors of that corporation, with all the powers of a stockholding director. I want you to see that in its proper setting. That man, from such environment voluntarily, unasked, thought it his duty to do that thing. Such is the new sense of social union, and when Bill Smith down in the forge or shop can throw off his jumper, wash his hands, and put on a collar, and sit on the board of directors, why you have hit Bolshevism in this country a terrible blow.

There is one of the signs of a new social union, a new relation with men. At this time wages are high in America, higher than they 
have been for many long years, but very few of you recall any attempt on the part of any responsible industry to cut down wages in the last six months; do you? I hare been looking for some such thing, to see if I could find it. I knew one man who said he was going to, but changed his mind and decided that he mould not; that it was not square. I do not recall a single case of a large industry that has niade any definite attempts to cut wages in the last six months. There may be such; I am not a rare of it, and I know of 20 cases that have come to my personal notice where the leaders of great industries employing thousands of men said to me that they thought it their main duty to keep those wages up to the last limit of their power.

There is a new consciousness in this country. You are to some degree interpreters of that feeling, because you touch intimately, whether you realize it or not, the lives of the very poor, who are not able to protect themselves. There are thousands of humble housewives spending on very high-priced necessities the hardearned wages of their husbands and sons. Their battle to make ends meet depends upon the fair weight and the just balance, and in that sense you have behind you both human and divine authority. You stand in a real relationship as the protectors of the poor. I saw a fellow the other day selling a beefsteak for 50 cents a pound, which was all right if anybody wanted to pay that price, but I didn't like the amount of paper that was sold at that price. So I always think of you coming into this rery scientific atmosphere to do a thoroughly human job; none the less human that lots of people may not know about it or some of them may kick about it. You do, practically, stand between the crook-perhaps we should be less severe on the fellow whose standards are low-and those who can ill afford to have those standards imposed upon. I think it is a fine jol. I like to come here and tell you so, because people like to be appreciated, and I heartily and thoroughly appreciate the rork you gentlemen do, which is a manifestation of the noral force of the country and a contribution to social well-being.

WEIGHTS AND MEASURES OF LATIN AMERICAN COUNTRIES, BY W. C. WELLS, PAN AMERICAN UNION.

Gentlemen of the convention, I do not want the idea to be entertained that I am here to answer Mr. Halsey. I never could answer Mr. Halsey, and I never intend to attempt it. I do not think anyone can. $\Lambda$ representative here of the American Metric Association, Mr. Richards, probably conld come nearer than I conld. My interest is not the same as that of Mr. Halsey. I am not a propagandist of the metric system or of the old Finglish system. I hare looked at this thing entirely from the commercial standpoint. I have observed commercial inethods in most parts of the world, and particularly Latin American countries, in which I have spent a number of years, and I know the language fairly well, and the customs. I have seen the effect of measures in conmerce, and that effect is in some cases very great; in others it is not very important.

My conclusions from my observations do not agree at all with what Mr. Halsey says his conclusions have been, but my opportunities have been better than Mr. Halsey's. Mr. Halsey has never, I think, vis- 
ited any South American country. He does not speak the Spanish or Portuguese language. He has not derived his information from people who can speak for those countries.

I want simply to say we are looking at the entire thing from entirely different standpoints. The interest of measure in commerce is not the same as the interest of measure in the industrial world. The two are the same in one sense, but not the same in another. Measure is of the same vital interest to commerce that it is to industry, but not in the same direction. Take, for instance, the manufacturer of a lock. There is bound to be used in the manufacture of a lock a measure of length. You can not possibly escape that, but in the commerce of locks there is but little measure involved. A man who uses a lock does not care what the interior dimensions of that lock are nor how much the manufacturer of that lock made use of measurement in manufacturing it. It is from that commercial standpoint, from what it means to the man who buys the lock, that I want to speak.

In the Latin American countries the old measures-I will say many things that directly contradict what Mr. Halsey has affirmed-the old measures no longer exist. They do not exist at all in anything that is imported. There is more or less of an existence in certain land measures and in certain measures of agricultural commodities in that the names of the old measures are used but the standards are of the metric system. In other words, that state of affairs is very simple to arrive at. because if you take away from a man the measuring instrument he loses that measure. The measuring instruments of the old Spanish and Portuguese systems are no longer sold in the Latin American countries; they are no longer procurable. The very few in existence mostly have been worn out, and they are not used at all. It is a very easy thing to make a substitute as anyone may find out for himself if he has been accustomed to using a certain measure for a certain purpose. Take, for instance. a cook who has been accustomed to use a pint measure. Substitute for that pint measure a half-liter measure some night when the cook does not know about it; she merely goes on using it as before. If there is no exterior marking it looks exactly the same; the cook will call it a pint, but it will be a half liter.

In the Spanish American countries you find the word libra used, which is an equivalent for our mord pound. To one traveling through Latin America and hearing the word libra used he would naturally conclude that that meant the Spanish pound, or the English pound, or some other pound. It does not mean that. It is the standardized metric reight of 500 grams. Sometimes it is used officially in that sense; for instance, in the official reports of IIonduras the rord libra appear's everywhere, but you will find it noted at the beginning of the table that the libra is 500 grams. Now, in one industry, and perhaps also in one or two supporting industries in Cuba, that word libra has an English sense. In the manufacture of sugar in the sugar centrales of Cuba, they use our American pound. The reason for this is that practically all of the sugar of Cuba, except that which during the war was diverted to England, comes to the United States. Much more than half of the capital inrested in sugar manufactures in Cuba is American capital. Threc- 
fourths of the managers and superior employees of Cuban centrales are Americans. You can account readily, therefore, for the American pound having penetrated into Cuba.

You will find here and there spots of Mexico where the English weights have penetrated. Very seldom will you find any English measures of length. You will find Mormon colonies in Mexico where they have carried the old English weights and measures with them and use them to measure with, but outside of Cuba and Mexico, and Panama, of course, you will not find any measuring devices in the English system anywhere throughout the Latin countries. You will find none of the old Spanish or Portuguese measuring devices; in other words, there is no possibility of using them, because they have not the devices except as I will explain hereinafter. There are no such things as bushels at all. There is, however, a standardized measure used in the retail shop, sometimes called a "bushel." There is no measure such as a vara unless it be an old one. There is none from the other countries unless one gets it from England or America. But that is immaterial from the commercial standpoint, because if the old measures were used they would be foreign to us and we could not conform to them in our industry. So, after all, the question of old measures is not of vital importance. The question of English measure does touch us, and it is particularly to that I want to direct attention.

There are certain lines of commerce in the Latin American countries, quite a number of them, where the monopoly in supply has been English or, more often, American, or sometimes Australian. You can not get these goods from any other country. In those cases the English and American manufacturers have disregarded the wants and customs of Latin America; they sent them what they wanted to send them; one had to use a left-handed saw although lie is a righthanded man. That is true of lumber. All of the lumber that is imported iuto Latin American countries is from America or Australia. Furtherinore, these imports represent perhaps 90 per cent of all what we would properly call lumber, although wood is cut in the country occasionally to make a peasant's hut. Wherever in a city lumber, properly so called, is used that is a foreign production in at least 80 per cent of the cases in all of the Latin American countries. In some it is entirely so. For instance, in Uruguay $\mathrm{Mr}$. Halsey will probably find the fact that Uruguay does not cut lumber; has not got it. Argentina has trees, but does not cut them. Brazil has enormous forests which could be manufactured into timber, but it is cheaper to lay down American lumber at Rio de Janeiro, Pernambuco, or anywhere else than to get the lumber 20 miles away. This is particularly true in Para, surlounded by forests. American timber is sold there. On the west coast of South America Chile is the only country that manufactures, lumber. Notwithstanding, Chile does not manufacture, at the outside, more than 33 per cent of the lumber used in Santiago or Valparaiso, and even in the south the center of the lumber industry of Chile, you will find Oregon pine and Australian gum sold. The lumber which goes into the Latin American countries is cut by the board-foot measure. It is bought by the boardfoot measure, but is not used by the board-foot measure. The man who builds a house uses a meter instrument to measure it. He has no foot rule, and would not know how to use it. He uses the meter 
rule entirely. That is the custom everywhere throughout the Latin American countries. That illustrates as well as anything else the method by which the English measure has penetrated into the Latin American countries. It has penetrated in those countries where a monopoly existed in the United States or Great Britain, or in some of the English possessions where they use the old English mcasures.

Take the case of coal oil. American oil controls in Latin America absolutely, except recently there has been a little Mexican oil, and for a number of years Mexican crude oil, and that is, as we all know, an American or English industry in Mexico. The American oil has golle into I atin Anerica in 5-gallon cans. The retail buyer buys the 5-gallon can and pours it into a liter measure and sells it to his customers. There are no quart or gallon measures used. He draws as many liters as there are in the 5-gallon can. The measure has no effect upon the oil. The man who buys oil knows nothing about the gallon, and yet all the oil that goes to South America goes in gallon measures. One would think here that English measure was the basis of the Latin American oil trade.

So it runs through all the industries of that kind. Take flour, which they get only from the United States, an absolute monopoly except so far as $\Lambda$ rgentina and Brazil produce it; in the northern States there is an importation from Argentina. In Brazil in the north, and in Central Amcrica and Mexico they get their flour from the United States. There is very little manufactured in Mexico. That flour is all in the customary half-barrel sack or one-fourth barrel sack. The man that sells that flour by retail sells it by the kilo. That is the rule everywhere. So it runs. Now there is no measure impressed in flour any more than there is a measure impressed in the thing itself, in the case of oil. But there are measures impressed to a slight degrec, but not cntirely, in certain other products in which we have a partial monopoly in Latin American countries. Take the question of agricultural machinery, for instance. That is a casc in which the measure is vitally important to the American manufacturer. It is a matter of vital importance to the manufacture of a mowing machine or any other agricultural implement that it shall be on a single standard, but measure is of but little importance to the user; whether the cutting bar of a mowing machine be exactly 5 feet or 150 centimeters is not a matter of much consequencc. The inan who buys it does not ordinarily care provided you stamp that thing with a customary measure, the measure that he knows. The man in Latin America does not want to be told that a collar is a 15-inch collar. He wants it stamped $38 \mathrm{~cm}$; but it does not mean anything in the manufacture. It is a mere conversion of terms.

That brings us to a rery important element that has led to a good dcal of misapprehcnsion to people who have not examined anything more than the surface of the matter. You hear a great deal of English measure being used in Germany, for instance, in manufacture, and in Holland, and in Belgium. That is true. It is also true that the metric measure is used in the parallel casc in England. Wherever England has shipped goods to Germany those goods have becn manıfactured by a metric standard. A large proportion of English textiles are manufactured on centimeter widths and in meter lengths for export to metric countries. Germany manufactures goods in yard 
lengths to be sent to the United States and Canada and England. That is a mere matter of detail. It does not mean that Germany has adopted the English standard because they manufacture for the English market, or that England has adopted the metric system because they manufacture for the French or German market. In South America, in all the lines of competing goods, the experienced manufacturer in England has manufactured according to the metric system because the English system was a handicap. For instance, in nearly all of the English textiles-in all, or so near all, the remainder amounts to nothing-where there is competition with French or German textiles, English goods come to Sonth or Latin America in meter lengths and centimeter widths. In some few cases where the Englishman has more or less of a monolopy in the textiles, and that is true of some kinds of wool cloth, as in waterproof cloths, that kind of a cloth is generally in the inch widths, but they are sold over the counter by the meter. That is the custom everywhere in the Latin American countries.

Whether the user will demand that an article be in the system in customary use comes to this: It is a question of how much he is handicapped by the unfamiliar thing. Now, what is the handicap to a man when he buys a yard of cloth when he wanted a meter or some metric length. The handicap to a dressmaker or to a tailor is that his patterns are on the metric dimensions, and, consequently, they fit in to adrantage on the cloth of the metric dimensions. Since they do not fit on yard measure, there is more wastage in using material measured in yards, just as there would be more wastage here if we had metric patterns to cut to for yard lengths and widths. That is part of the handicap. Another part of the handicap is that the dressmaker or tailor tries to fit them in and that takes time. $\mathrm{He}$ is not accustomed to know, as he would know in metric lengths, which patterns lie next each other in order to get the best advantage out of the cloth. He has to learn orer again. It takes 10 times as long: to lay his patterns out on the cloth to get the advantage out of it if he is using the unfamiliar units. Now, we come back to whether there are not some other lines of commerce where the handicap is not so great.

First, let me say this: The handicap to my mind is just the margin between an unsuccessful and a sucessful business. It may be only 2 or 3 per cent, but it may be enough to absorb the advantage that one has over the other fellow. There are certain lines of industry in the Latin American countries in which the measure counts ritally to the man who uses it. If you take the statistics of Latin American countries-and I am more familiar with them than any man in the world, because I am the only man who compiles them in their entirety-you will find it remarkable that the Latin American countries do not import from England or the United States any goods, or scarcely any goods, in which the measure is vital to the user. This is a demonstration beyond all question of the fact that therein we have fallen down.

In 1913, prior to the outbreak of the war, the United States exported to Latin America more goods than any other country in the world. That year for the first time we passed England, 60 per cent greater than England. Notwithstanding that enormous hold $155530-20-9$ 
we had on the Latin American trade in those countries, nevertheless, where the measure was vital to the user-in other words, where the things that were bought were to function in relation to something else and would not function if the measure were not exact-they bought none of those goods from the United States.

Take the case of one of the firms that Mr. Halsey reports upon. They answered his questionnaire, and he said they did not see any necessity for adopting the metric system in shipments to Latin American countries, as they had sold goods there successfully for a good many years. The thing sold was machetes. It does not matter whether the machete is 35 centimeters or 14 inches long. It is like an axe. It is not material whether the cutting edge varies oneeighth or one-half inch. But it is material if the man wants a chisel to cut an exact mortise, and this firm sells none of that kind of chisels. It is a matter of considerable significance if a plumber wants plumbing-repair parts, unions and joints and pipings, that measure must be exact, and it is remarkable that all of these goods were French or German, and yet France and Germany did not lead in that industry. You might think that could be accounted for by what I first said, that this was more or less a monopoly, but it is not.

In the case of all of the tools of precision that are used in the Latin American countries on woodwork, where the cutter head must be of exact width, the United States and England furnish none of them. As I said once to Mr. Halsey, ask your correspondents why it is that they can sell so much of one kind of their tools and so little of another and they will probably answer that Latin America does not use the latter; but they do. I can show you the statistics, but they get them from Germany. They comprise those things where measure actually counts to the user. The degree in which the measure counts to the user may go anywhere from zero up to 100 per cent. It is 100 per cent in the case of the man who wants to make a pipe connection. It is practically nothing in the case of the man who buys a watch. It is only to the watch repairman that the measure counts. There is no handicap on locks sold in South America, except on the exterior dimension, and it is not great there. The interior dimension of the lock or watch is of no consequence to the user. The result is wo send American watches to Latin America, and they are sold along with the Swiss watch. I believe some of our watches are manufactured on the metric scale now, but that is of significance only to the repair man.

In all of the countries you will find these facts. That brings me back to the point which should be, I think, considered by everyone as more or less basic. It is this: The Latin American countries have no absolute standards of their own. Mr. Halsey showed on his map of the world here the countries in the world that have standards. They are Great Britain, Germany, France, and the United States. Outside of these the other countries have standards more or less imposed upon them. The standards, and that applies almost entirely to the standards having reference to the measure of length, are created in manufacturing. The manufacturing industry of the world is centered in the United States, England, France, and Germany. The rest scarcely count. Those countries have their own standards. You can not ship to France goods on 
the inch and foot and yard measurement because France will not accept them. You can not create a monopoly. The individual standard is there. It resists absolutely the intrusion of foreign goods. You can not send to Germany goods on the English standard, for they will not take them. But you can send them to Turkey, to Russia, and to I atin American countries because they have no standards of their own. The way that works is this: What a man sends into a country is forced upon the people there. He sends goods because he makes a profit. If he finds there is too great an impediment, he retires from the field or overcomes the impediment. If he sends his goods to Brazil measured in the yard measurement and finds German goods in the metric are outselling them, he will adopt the meter if he can. If Brazil itself was a manufacturer of machinery, for example, it would supply its own market to a large extent, and the foreign countries would have to conform to their measurement, but, since it is not a manufacturing country, it has no standard to which the foreigner is forced to conform. That runs through all the world-China and everywhere else. Wherever you find the bulk of the trade in the hands of England in a nonmanufacturing country you will find the English measure has more or less penetrated. I will speak in a few minutes of just how far it has penetrated. Where you will find France or Germany has control of the goods imported you will find the metric measure has penetrated there. Wherever the American goods have penetrated you will find that the American measure has penetrated to a certain extent.

You will find, if you look in one direction, a very considerable amount of apparent penetration of American measure in Latin American countries. If you look in another direction, you will see none of it. It depends upon which way you are looking.

You will see that we are shipping flour, lumber, textile goods, and machinery to Latin America where formerly we did not. In 1913 such exports amounted to about $\$ 326,000,000$ worth. Ninetynime per cent of this, I suppose, is manufactured according to the English and American measures, and not more than 5 or 10 per cent of it was denoted in metric measures by conversion from the English.

That looks as though the English measure had penetrated a great deal into Latin American countries. It is the case of coal oil and the case of lumber; immediately the man gets hold of them, as soon as they pass into the wholesaler's hands, or at the very customhouse, he converts them into the metric scale if he can. That runs through the industry everywhere, and if you will start at the other side, as I have started, with the people themselves, with wliat they do in the shop, you will find there is nothing but the metric scale.

Take this argument, and let us see how it works out. Suppose you read in a Brazilian journal, or some Brazilian makes the assertion, that the coffee industry of the United States is on the metric system of weights. You would laugh at that as ridiculous, and yet every pound of coffee that comes into the United States from Latin American countries, and that is 98 per cent of it all-three-fourths from Brazil alone-every pound of it, every bag of it, comes here in metric measurement, in 60-kilo bags. Thousands of wholesale dealers do not know it is in kilo bags; they think of 132-pound bags, and think that 
English measure is being used. But they are measuring from 60 kilos. The coffee industry of the United States is not on the metric basis at all. The customhouse weighs it by pounds, the wholesaler buys it by pounds, the retailer sells it by pounds, and you drink it in a pint cup, and you know how many pints a pound will make. That is exactly what happens from this end. That is exactly the kind of evidence that people opposing the nietric system are producing. They say that lumber, machines, and everything else are on the English scale, yet it is just exactly the converse. All the cocoa and chocolate we buy, everything we buy in Latin America, is measured in the metric system and we buy and pay for it in the metric system. We sell it here on our own scale.

Just one or two little references to things that may appear, perhaps, misleading. Take the cattle industry of Latin American countries. Cattle are not bought by the kilo or pound there by the packers. You buy cattle there by the head, like horses. It is probable that in some few localities, in which American influence has had its effect, they occasionally weigh cattle. In Mexico cattle are sold by the head. The cattle are cut up and manufactured in all the refrigericos, the slaughtering establishments of Argentina, and about fourfifths are in English and American hands, all on the kilo basis. There is no other way to measure it. It comes in at the door by the head, 60 to 200 pesos per head. It is cut up and sold by the kilo, even to England. All of the frozen meats from the Platte region go to England marked by the kilo; manufactured by England in Argentina and sold to the English dealer, London market, by the kilo. The dealer in London sells it by the pound.

Now, just one last word in closing in reference to the inexactness of the lind of information which is produced by people here who are opposed to the metric system. I am not an advocate of it, but I want to see the truth told. Take, for instance, the statement you heard that in the silk mills of France the dernier was used as a unit of measurement. The dernier never was the unit of measure of length in any silk factory in the world from the beginning of time to the present day. It never was and never will be. The dernier is nothing but the pennyweight; that is the equivalent, so far as a French unit can be changed to English. The dernier is the pennyweight. They all go back to Venice, and perhaps to Byzantine, if you go far enough. The ancient measures were very valuable things, diamonds at one time, gold and silver at all times. It was the measure of silk when silk was equal by weight to the value of gold. It was sold as against gold on the Venetian market, by putting gold on one side of the scales and on the other side, silk. The buying and selling of sillk by pennyweights passed out of use hundreds of years ago. No silk was ever manufactured on any machine ever built that took account of the dernier in the weights. It could not be. It became a specialized standard, as you gentlemen will recognize. It became a conventional sign, the dernier, or pennyweight, for a certain thickness of silk, a certain quality of silk. In the silk mills of New Jersey to-day, they speak of sill as of a certain pennyweight; it is a quality of thickness.

So far as the aune is concerned, in the old days that was the measure by which the retailer bought cloths in England, France, Belgium, Flanders, and practically all of Europe. It was about a yard 
and a fourth in length. Perhaps some of you older men saw in the old textbooks the ell. That was another old measure for cloth, genelally something around 45 inches in length.

The French in 1792 adopted in a measure the metric system. It did not come very quickly. In 1812 they standardized the metric system in the same way that Chile and other countries did; that is, they varied the old measures to malse them conform to the new. They standardized the aune at 120 centimeter's. The aume to-day is used in the silk factories of France to this extent and no further. There is no measuring instrument, no machine, in France that measures by the aune. The ratio is 6 meters to 5 aunes. It is used in paying pieceworkers. It is nothing more than that. All the French silk factories of Lyons purchase and sell everything else by the meter but since the workmen like to use the old term and get paid in that way, they use this 6 meters and call it 5 aunes.

The Acting Cliamman. Before going further, I would like to know if it is desired to have any discussion on this paper at all. Those in favor of continuing discussion will signify it by saying "Aye;" those contrary minded "No."

(The members expressed a desire to dispense with discussion.)

\section{DISCUSSION IN REGARD TO PROGRAII.}

Mr. Fine. I move you, sir, that the address delivered by the Hon. William C. Redfield be printed, so that it will be possible for each delegate to take it home with him. I think it was one of the best addresses made to show the sealer where he stands in his community.

If it is not possible, Mr. Chairman, to have it ready for the sealers to take with them, I would like to have a copy sent as soon as possible.

Mr. Goodwin. It is with great pleasure that I second that motion. I believe that each sealer representing the different. States of the Union should have a copy to present to the governor, because I believe it is in the interests of humanity and honest weights and measures.

Dr. Reichmann. May I amend that to send to guests also?

Mr. Farrell. May I ask if that address of Secretary Redfield will be printed in the report in the minutes of the conference?

The Acring Criairman. It certainly will.

I may state that we will get it out for you withont any resolution.

Mr. STEwarT. I have a motion to make previous to which I want to make this statement. It is not my intention nor the intention of those who liave talked with me on this particular question to treat anyone with discourtesy, but we have some things in our system that we wish to get out.

Therefore, I make the motion that the reading of all papers be dispensed with until certain questions that are in the ninds of the delegates be considered by this convention.

Mr. Tucker. I second the motion.

Mr. Fine. I want to oppose that motion, Mr. Chairman. I think an interesting paper on the program is by Dr. Alsberg. I would like to hear it.

The Acring Criarman. Dr. Alsberg will not read his paper, This motion is to have all papers submitted without reading. 
Mr. Stewant. No, sir; the object of this motion is that all papers be dispensed with until the relegates get through with certain matter's that they want to hear discussed, such as the questions of marking the rreight on packaged meats, oil pumps, and a number of others that come up every lay in the field. WT want time to consider them.

The Actung Cmarman. I might stato that that is equivalent to dispensing with the program, which is arranged. J)r. Alsber is is (xpected to be here at 1 o'clock. Shall I tell him that you do not want to hear him?

Mr. Mikeseld. With reference to No. 29 on the program, the first thing in the afternoon, inasmuch as Dr. Alsberg has been invited, I know erery member of this conference is interested in hearing him. Nothing should be done to detract from or set aside that subject, the net-reight amendment to the food and drug act.

Mr. STewar'. I will amend my motion by stating that we proceed in accordance with it after we have heard that paper.

Dr. Rerchmann. I will offer an amendment that it be left to the rliscretion of the chair.

The Actung Cuampar. I do not see any objection to interrupting the program, but I would like to get the next three papers off. I (an ask Dr. Alsberg to make his remarks brief.

Mr. Stewart. While some of these papers were being read, we have been holding conferences on the outside.

The Acting Crialraran. So I have observed.

Mr. STzivaris. We hare decided that we want to get into discussion on those questions that lay most closely to our hearts.

The Actrag Chamman. Have you a list of questions you want discussed? Do you want to proceed to new business? The suggestion has been made that the program be carried on until 3 oclock. Is that agreeable?

Mr. Stuivart. Well, do that.

The Acting Chulrman. If that is agreeable, I will not put the motion, unless there be objection.

\section{FEDERAL REGULATION OF WEIGEING AND MEASURING DEVICES, BX JOSEPH J. HOLWELL, COMMISSIONER, MAYOR'S BUREAU OF WEIGHTS AND MEASURES, NEW YORK CITY.}

Mr. Chairman, ladies, and gentlemen, I regret very much that there has been introduced into this conference opposition to the reading of papers, because the first time that I hare ever been asked to prepare a paper and read it, is the invitation extended to me by your chairman.

I have taken rather a dry subject, but I presume it is going to be interesting, as it is the intention of your committee on resolutions to introduce a resolution which will bring the subject up for discussion to-morrow. I have made it as brief as possible.

To those who have watched this country's wonderful growth in commerce, population, and wealth, and who have realized the necessity for the use of proper devices in the measuring and weighing of those commodities which are sold by either weight or measure, there has been a keen desire that proper legulation and control shall be exercised ovtr such derices by governmental authorities. Al- 
though millions of dollar's are spent annually in this country for commodities sold by either weight or measure, comparatively few of the municipal or State governments have done anything to properly safeguard the purchasing public in compelling the manufacturers of such devices to submit their scales and measures for approval before same could be sold.

Realizing the need of protecting the great purchasing public of the city of New Iork, forner commissioner of weights and measures, Hon. John L. Walsh, succeeded in haring an ordinance enacted in 1910 by the local board of aldermen giving the necessary authority to the commissioner of weights and measures over the sale of all measuring and weighing devices. This ordinance is as follows:

SEc. 384a. No person, firm, or corporation shall sell, offer for sale, or give away any weights, scales, beams, measures of any kind, or the tools, appliances, or accessories connected with any and all instruments or mechanical devices for weighing or measuring intended to be used for the purchase or sale of any commodity or article of merchandise, or for public veighing, within the city of New York, nntil a type or types of the said weights, scales, beams, measures of every kind, or the tools, appliances, or accessuries connected with any and all instruments or mechanical devices for measurement or public weighing, with specifications as to construction, shall have been submitted to and approved by the commissioner of the mayor's bureau of weights and measures. The commissioner shall, when said types are approved, designate a serial number, which serial number shall be used in identifying the type approved. A record of the serial numbers and to whom furnished shall be kept in the office of the commissioner of the mayor's bureau of weights and measures.

Any person, firm, or corporation who sells, offers for sale, or gives away within the city of New York any weights, scales, beams, measures of any kind, or the tools, appliances, or accessories connected with any and all instruments or mechanical devices for weighing or measuring intended to be used for the purchase or sale of any commodity or article of merchandise, or for public weighing within the city of New York, that do not comply with the specifications and type submitted and approved by the commissioner of the mayor's bureau of weights and neasures, as provided in this section, shall be liable to a penalty of one lrundied dollars for each and every such offense.

The results obtained from the nine years' operation of this ordinance has justified its enactment. Prior to its enactment many defective and fradulent scales were sold to the merchants in the city of New York, necessitating the conclemnation and confiscation of thousands of them. To-day, nothwithstanding that the number of scales and measures used run into the hundreds of thousands, it is a rarity to find defective scales in use. In fact, the scales that are confiscated are those found in use on pushcarts, which, owing to their hard usage and their exposure to the elements, easily get out of order. The initiation of such regulatory control by the New York City weights and measures officials resulted in the introduction into use of a more substantial and improved type of scales by the manufacturers of this country and the change has not only benefited the city of New York, but has had a corresponding beneficial effect upon the entire country.

This nine years' test in the largest city of the country, with a population estimated to-day at close to $6,000,000$, shows the possibilities which could be accomplished for the entire 48 States by vesting in a central mandatory authority the power of enforcing the manufacture of scales and other measuring devices based upon right principles. The central mandatory authority, in my judgment, should be the National Bureau of Standards of the Department of Commerce, be- 
cause this Bureau, with its efficient, trained staff and its laboratorial equipment, is especially qualified to deal with and pass upon all derices submitted to it for its approval.

In order to ascertain the riews of the scale manufacturer's of this country regarding national serialization by the National Bureau of Standards. I sent the following lettel to 45 of the most prominent firms engaged in that industry:

A PRIL 2, 1919.

I have in preparation a paper dealing with the urgent need for the serialization of all scales, manufactured or sold in the United States, by the National Bureau of Standards. I have come to the conclusion, after 15 months' experience as commissioner of weights and measules for the city of New York, that vesting such authority in the National Bureau of Standards will not only improve conditions in so far as the purchasing public and the purchaser of scales are concelned, but that it will at the same time centralize authority for the scale manufacturers and facilitate the introduction of their particular trpe of scales on the market and materially assist the reights and measures officials of the country in their work.

I would appreciate if you will let me have vour views on this question. I would also like to have from rou, first, an approximate estimate of the number of scales now in use in the United States in the sale of commodities; second, approximate estimate as to the number of such scales manufactured in the United States in the rear 1918.

The majority of the responses were farorable to reposing such power in the National Bureau of Standards, but my attention was called to the need. if such authority was granted-

1. That centralization of such authority should mork to the advantage of all; the small as mell as the large manufacturers.

2. That regulations should not be too drastic in calling for terhnical requirements which would make a commercial proposition impossible.

3. That the small dealer should not be compel!ed to inrest so large a proportion of his capital as to work a hardship because of the extreme technicả accuracy demanded.

4. That a national bureau is apt to run more to theory than to practice and needless expense placed upon the scale manufacturer in complying with its requirements.

5. That some arthority other than the courts be instituted to reriew the decisions of the national bureau in the erent that one desired to appeal from its decisious, with the privilege of final review by the courts.

From my own personal experience and that of my prerlecessors, I feel that if the policy followed by the mayor's bureau of weights and measures of the city of New York rere adopted as the policy of the National Bureau of Standards, that few complaints rill be forthcoming from the manufacturers of weighing and measuring devices.

In New York City we hare endearored to conduct our bureau on practical lines, ritl an eye not only for the protection of the merchant who purchases a reighing or measuring device, or the purchaser of a commodity sold by reight or measure, but also for the manufacturer of the derice. Te hare realized the time, energy, thought, and capital that the manufacturer has put into his device, and our requirements hare not been so exacting. for example, for the scrale used in the sale of potatoes as for the one used in the sale of butter. 
I realize, howerer, the potency of the al'gument of the manufacturers that sucl a bureau is apt to become theoretical instead of practical, because in the final analysis the bureau's requirements irould be the viewpoint of a single individual. If that individual were a broad, practical mau, a nian possessing not only mechanical and executive ability, but one able to realize what liardship a drastic decision of his would work upon a great industry, there would be no need of placing any checkmates upon him. But, uufortunately, that nanner of man is not always placed in authority, and only too frequently we have men placed in public office who fail to realize the need of exercising proper discretion and giving the necessary thought to matters coming before them.

In view of the fact that the several States are vitally concerned in the proper regulation of all weighing and measuring devices and imasmuch as millions of dollars have been invested by private capital in the manufacture of such devices, I believe it would be adrisable that a board of review consisting of four State or municipal weights and measures officials and three manufacturers of weights and measures be named by the Secretary of Conmerce. This board of review would in a sense be a court to hear any appeals from a manufacturer who might feel that he had been discriminated against either by the promulgation of a too drastic regulation of the Bureau of Standards or its refusal to approve the device submitted. It would not be necessary for this board of review to sit permanently in Washington. It miglit meet biannually to elect a chairman and secretary. Its members could receive copies of the papers of the particular transaction, pass upon same witl their recommendation that the Bureau of Standards be sustained or not sustained, and the combined findings submitted to the Secretary of Commerce for decision. The members of such a board would serve without pay, with the possible exception of the secretary, traveling and clerical expenses being allowed.

In making the recommendation of placing snels power to serialize and to approve all types of weighing and measuring devices in the hands of the National Bureau of Standards, I am not ummindful of the opposition of those who are opposed to such action. The opponents of such necessary legislation predicate their opposition on two points:

First. Congress has no power under the Constitution to make such a law.

Second. Such a law if passed would be harmuful and detrimental to the business interests of this country.

It is uot my intention to enter into any discussion as to the constitutionality of such legislation, because I am a manufacturer and not a lawyer, but the purpose of every good law is to render justice, and commou sense should be followed in its interpretation. It would appear, therefore, that a law which was in every sense progressive and which aimed to protect the interests of both the nianufacturel and the purchasing public of the several States, if passed upon by the Supreme Court of the United States, would be declared constitutional in view of the fact that it protected all of the people and not some of them. 
I fail to agree with the opponents of such legislation that "it would be harmful and detrimental to the business interests of this country." I suppose by "business interests" is meant those who hare invested their capital in the manufacture of weighing and measuring devices. Let us suppose that the 48 States followed the example of the city of New York and passed similar laws to theirs, controlling and seralizing all weighing and measuring devices before such could be offered for sale in the several States. This would mean that the manufacturers of the country would be compelled to submit their devices to 48 weights and measures officials instead of to one central authority. It would mean, possibly, 48 different sets of rules and regulations. It would mean 48 additional mechanical laboratories to be maintained instead of one. Whether such legislation giving authority to the National Burean of Standards is enacted or not, the sereral States, if they are to keep step with the times, must eventually adopt proper control of weighing and measuring devices offered for sale in their respective States. The question is: Which will prove more helpful to all, a centralized control or an individual State control?

A central mandatory authority along the lines I suggest would prove a wonderful help to the reights and measures officials of the country, because it would enable them to concentrate their efforts to detecting the cheat and the short-weighter and to educating the purchasing public how to protect themselves when purchasing particularly the necessaries of life. In New York I have said we have few defective scales, but our concern is with "the man behind the scale," and that is the man in whom every weights and measures official is interested. When we can impress upon the purchasing public the great need of protecting their purses by seeing that "the man behind the scales" does not manipulate the scale when weighing a commodity; that he does not deliberately overcharge; and that he does not insert items in the weekly or monthly account which were never delivered, then I feel that we weights and measures officials will have accomplished some of the important features of our work.

But, notwithstanding the wonderful improvement made in weighing and measuring devices, there is still great need for improvements in them in some parts of this country. As men interested in this subject, I feel that we should rise above personal interests and that we should lend every aid possible to enacting the necessary legislation to permit the National Bureau of Standards to take over the work of approving and serializing all weighing and measuring derices offered for sale in this country.

\section{DISCUSSION OF ABOVE PAPER. ${ }^{1}$}

The Acting Chairman. We have a few minutes before luncheou, and this paper is open to discussion.

Mr. SweENex. I am opposed to the National Government enacting any such legislation as has been recommended in Mr. Holwell's paper. In the first place, it will make the State inspector of weights and measures a nonentity, because just as soon as the National Gov-

${ }^{1}$ See also discussion on this subject on pp. 50-51, and resolution on p. 205 . 
crnment enarts this legislation and power is placed in the hands of this bureau, or whatever authority it is placed in, they will come to your State or send to your State to give you orders what to do. The National Burcau of Standards furnishes every State in this Union with the standards of the country, and there is no reason why each State can not attend to its own business. Over 50 years ago this Gorernment furnished to every State in the Union a set of standards, but the States could arlange their local matters. If this legislation recommended by $\mathrm{Mr}$. Holwell goes into force, a lot of you people here to-day will find yourselves ont of positions. There is no reason why the fellow who has not a large technical knowledge should not be pernitted to aspire to these positions. If you are compelled to take examinations fixed by certain individuals known as the Civil Service Commission, a boy going through school to-day can pass an examination that you and I and other's can not pass. You can not get in this Bureau to-day unless you can pass that examination. How many of you can pass it? Not 10 per cent in the conference. The founders of this Government in mapping out a system of government fixed a sistem for the State, county, and city, and we have lived prosperously under it for 145 years. I do not see any reason why we should allow that piece of legislation to go through.

Mr. Farrell. We all hold political jobs and have certaill fundamental ideas regarding government. Mr. Holwell's predecessor in office held a political position and was of the opposite faith of Mr. llolwell. The previous commissioner's telm of office having expired, another man comes in and lias views exactly opposite. How much better it is to have one single administration such as they would have in Washington than to be put to the expense, as some of the manufacturer's are, of changing practically the whole scheme of lisanufacture for each State of the Union when the liead of a particular department of weights and measures changes. I belicre that crentually we are coming to the centralization of goveriment in Washington.

The Acting Chairman. Before we take a recess I would like to make an amouncement. It is that $I$ hope everybody will be here promptly at 2 o'clock. There will not be any delay in that case.

(Thereupon, at 1 o'elock p. m., the conference took a recess until 2 (i) ork p. ni.) 


\section{SIXTH SESSION (AFTERNOON OF FRIDAY, MAY 23, 1919).}

The conference reassembled at 2 o'clock p. m., Mr. L. A. Fischer, secretary, presiding as chairman.

THE PROBLEM OF WEIGHTS IN THE HANDLING OF GRAIN, BY J. A. SCHMITZ, ASSISTANT WEIGHMASTER, CHICAGO BOARD OF TRADE.

The weighing question in the handling of grain plays an inportant part in that important branch of onr industrial life. I believe I am justified in saying that there is no other commodity, of equal valne per pound, that is weighed in such wholesale quantities as is grain. No doubt there are some commodities weighed where the total tonnnage will exceed that of grain and other commodities of large tonnage that will exceed the per pound value of grain; but the requirements in the grain trade are such that accuracy in the weighing of large quantities of grain at a minimum of expense in time and labor is imperative. This accuracy calls for scales of large capacity and with a degree of fineness in proportion to the value of this costly product; and it also calls for scales possessed of a high degree of permanent accuracy. After snch a scale has been properly designed, carefully manufactured, and correctly installed its continned accuracy is dependent largely on the skill and equipment of the scale inspector in whose charge it is placed. For, obrionsly, the maintenance of a scale includes the careful attention of a competent inspector, with suitable equipment to prove its accuracy, or to bring to light inaccuracies and the need for repairs and adjustment, shonld they exist. By suitable equipment I mean test weights of known quantities and in sufficient number.

It is plain that the weighing results obtainable by a careful, conscientious weighmaster depend largely on how well the manufactmrer, the builder, and the scale inspector have performed their work. On the other hand, no amount of care in the construction and erection of a scale will bring the desired weighing results if the weighmaster is careless, inefficient, or dishonest. Each branch of the service, then, whether manufacturer, builder, inspector, or weighmaster. must lend its best efforts to the end that the sum total of all these efforts is accurate weights.

Now, it is my desire to lay special emphasis on the dnties of the scale inspector as represented at this gathering. It must be plain to you that to obtain that accuracy which is an indispensable element in commercial transactions having weight for their basis of settlement. the testing of scales becomes paramount. Hence your men have invaluable duties to perform.

Right here a word about the department I represent may be of interest. The department of weights of the Board of Trade of Chicago was organized to furnish weights independent of the interests of either the bnyer's or sellers of grain and seed; that is to say, weights that can be used as bases of settlement. To carry out this 
plan comprehensirely it was necessary to appoint a chief weighmaster and a force of assistants called deputy reighmasters. Now, in the early days the duties of these deputy weighmen were simple and were generally confined to a reading and recording of the weights on the scale beam. Howerer, as the department grew in importance and as progress was made in weighing matters, improvements in the service were found necessary, until finally the actual checking and recording of the weights themselves, while of the utinost importance, became but one of many duties, until now the service of the department begins in the ontlying "railroad arrival yards" and does not end until the grain is finally paid for. The service now includes car inspection, police service, custodianship of the grain in elevators, and the care and inspection of scales and equipment used to handle the grain to and from cars and boats.

In the days long ago, when there were few comparative weighings, and when scales generally were few in number and often unreliable in quality, and when the weighing was performed in a more $\mathrm{or}$ less perfunctory manner, and when the efforts of weighing departments were directed more toward the preventing of the larger errors than toward the securing of fineness in weighing, the matter of a close adjustment and of a high degree of accuracy were not regarded as of much importance. But all this has been changed, until now the highest possible degree of correctness is required and demanded. To secure such a high degree of accuracy, an improvement in the grain-handling equipment and in the methods of weighing became imperative. But, most of all, it became necessary to provide scales that would meet the more exacting requirements demanded, and also to provide for the care and maintenance of these scales.

This brings us directly to the subject of scale inspection and scale testing and to the oft-repeated query, "What constitutes a sufficient amount of test weights for testing scales used in the weighing of grain?"

$\mathrm{Now}$, to determine the required number of test weights properly to test, for example, a hopper grain scale, we must consider, first, the tolerance allowed, and, second, the sensibility reciprocal in its relation to the greatest error that will remain undetected because not visible. And right here let me quote the accepted definition of sensibility reciprocal:

The sensibility reciprocal is the added weight required to be placed upon the platform to break or turn the beam from a horizontal position in the middle of the trig loop to a position of equilibrium in the top of the loop. This may be determined by subtracting the weight instead of adding it, or by using the sliding poise on the beam, if this be done without jarring the beam.

As scale inspectors you all appreciate the importance of applying literally the definition I have just quoted. Obviously, the less the amount required to turn the beam, the smaller will be the amount of rariation not visible to the inspector. For example, if it takes 1 poind to turn the beam from the center of the trig loop to the top or bottom, an error of one-half pound, or eren less, would be easily perceptible. But, on the other hand, if it takes 10 pounds to turn the beam a like distance, one-half pound would not be visible; and if such a scale is tested with but 1,000 pounds of test weights, errors in excess of the tolerances provided for grain scales would go undetected. 
In view of the foregoing, it is plain that any specifications for scales to be complete and of practical assistance must prescribe a maximum range for the sensibility reciprocal, as well as limits for the error permissible in the ratio of the scale. It follows, then, that, by considering both of these factors, we can in all cases accurately determine the exact amount of test weights needed.

The specifications compiled by the scale committee for the grain interests in Interstate Commerce Commission case No. 9009 provide for a maximum sensibility reciprocal for a tolerance on the ratio of the scale and a tolerance on the hanger weights. The maximum sensibility reciprocal ranges from 1 pound on scales of 3,000 pounds' capacity to 15 pounds on scales of 120,000 pounds' capacity or more. The tolerance on ratio is one-half pound per 1,000 pounds. The amount of test weights prescribed by this committee for testing hopper scales, based on the tolerance and the prescribed sensibility reciprocal, approximate 8 per cent of the rated capacity; and, further, the specifications also provide that scales shall be tested "empty" as well as "loaded." Hence, 10,000 pounds of test weights are required to test a 2,000-bushel (120,000-pound) scale, since this is 8 per cent of its capacity.

Be it remembered that the principle involved in the determination of the quantity of known weight required to test hopper grain scales, as set forth in the specification referred to, is equally applicable to scales of any type and used for any purpose, since in any case the tolerance and the maximum sensibility reciprocal allowable determine the amount of test weights that must be used to make an efficient test.

There is another important matter that enters into the testing of scales, and that is the skill, care, and efficiency of the inspector performing the work; for, be it remembered, the scale inspector who approves the scale, thereby placing it in service, assumes in large measure the responsibility not only for the scale's accuracy at the time the test is made, but also for its permanent accuracy and its dependability as a weighing machine. The scale inspector, as you can plainly see, is in a position either to commend or to criticize the work of the designer, the manufacturer, and installer of a scale, for his periodical tests of the scale give him unusual opportunity to make observations and collect data concerning the scale's performance. And, moreover, if his criticism be constructive, it will be of assistance to those whose labor he reviews. His cooperation should be of extreme benefit to the other divisions of the craft and to commercial interests in general.

In closing, let me say that the greater the consideration given by scale inspectors everywhere to the size of the sensibility reciprocal of the scales they test, and to the amount of known weight requisite, will increase the sum total of satisfactory results materially. And my hope is that you will carry this message home and use it in your propaganda for greater accuracy in scales and weights.

DISCUSSION OF ABOVE PAPER.

The Acting Chalrman. Are there any questions?

Mr. StewarT. I believe I understood the gentleman to say that by taking 8 per cent of the capacity of the scale in test weights he could make a sufficient test of the scale. Is that correct? 
Mr. Schurtz. That is correct. That was the decision of this committee on grain scales, who decided that a minimum of 8 per cent of the rated capacity of the scale would be required, providing the scale was within the maximum range of sensibility reciprocal prescribed by the committee. The allowable tolerance is one-half pound in each 1,000 pounds. In other words, the committee decided that error greater than one-half pound per 1,000 would be visible to the scale inspector with the amount of test weights specified and that the scale could be maintained within the tolerance.

Mr. Stewart. I would like to follow that question with another. Do you not believe that, even though you do not have that amount of test weights, it would be a fairly complete test if you would use some sort of load and build the scale up to its capacity?

Mr. Briggs. Ten thousand pounds, which he mentioned in connection with testing 120,000-pound capacity scale, was the minimum amount of weights allowable. These weights were to be used in building up as you suggest, but you can not build up from an ounce weight to test big scales. That is the minimum amount to start the building-up process.

Mr. BARNARD. As a matter of information, I would like to ask Mr. Schmitz the amount of tolerance he allows on a grain scale. In the city of Battle Creek our food factories are buying a great deal of grain and oftentimes disputes come up as to the weight of the same, and our department is called in to settle a dispute. To get down to the question, just what tolerance would you allow per 10,000 pounds?

Mr. Schmitz. I quoted a tolerance of one-half pound per thousand, as agreed on by this committee. As a matter of fact, a good many of the grain-weighing departments are staying within that tolerance or do not permit so large a tolerance. But these specifications were for the whole United States, and we wanted to allow that for departments poorly equipped and not well organized. We all felt that one-half pound tolerance was the limit to be allowed. I believe tolerances ought to be held down. Our practice is to work as close as the inspector can possibly work. I realize that inspector's are merely asked to approve or condemn scales. Our function is somewhat different. We not only approve and condemn scales, but we also make reports, and when we find a visible error in the scale we inake the correction absolute, if we can.

Mr. Barnard. That was the point I wanted to bring out, because if a scale showed an error of 5 pounds on capacity it would be within the tolerance, but that means considerable to a concern buying wheat at the present price. It runs up rapidly. It mounted up quickly in the amount of grain this particular concern was buying each month.

Mr. Schmixz. One dollar and twenty-three cents on a thousand bushels.

Mr. Mrkeser.l. I believe I understood Mr. Schmitz to say that an effort was made to come within that tolerance which he nanied theire. Would it not be better to say that the weighmaster, or whoever is dealing in the wheat, should make it a point to get accuracy first and then, if he falls below accuracy, the tolerance is allowed. A tolerance is not for the purpose of allowing people to give a short- 
age. Each weighmaster and each dealer are supposed to reach that point of perfection which we call accuracy. If he should fall below it through some means not controllable, then the tolerance comes in.

Mr. SchMitz. In response to that, theoretically there should be no tolerance. Every scale should be 100 per cent correct, but in practice we find they are not. In fact, we have considerable trouble holding them within the small tolerance. When we decided on onehalf pound per 1,000 we thonght we had gone the limit, and no scale must have an error larger than that. That is the limit. If an inspector should test 10 scales and find each of the 10 one-half pounil per thousand in error in the same direction then he would have found, possibly, a scale inspector of unusual ability and also some very fine scales. This would be true if one could take advantage of that tolerance in one direction. But we do not find that. We find scales in error on either side of accuracy. However, I feel that the one-half pound per thousand is ample, probably too much, but I believe the allowance on the small scales used throughout the country is in excess of that tolerance.

Mr. Strwart. You were asked a question a moment ago if you allowed the tolerance on the grain. If I understand that question it was if a man was weighing 1,000 pounds, and the delivery amounted to $999 \frac{1}{2}$ pounds, he would call it a thousand and it would be all right; you don't allow any greater tolerance on grain?

Mr. Scrmitz. That would be a commodity tolerance, and I confine myself to scales; simple the accuracy of the scales.

Mr. Briggs. If the majority of you men here come within that half pound per thousand in your work, you are going some. To actually make a scale meet that requires much skill, and when the grain department is meeting that tolerance it must be a pretty wellorganized one. Ten thousand pounds in test weights is needed to test these big scales, and that load has to be applied with great skill.

Mr. Mikesell. Do not use tolerances to make short weight.

Mr. BRIGGS. I was just going to suggest that this tolerance is so small for ordinary purposes that you can not manipulate unless you are a good one. If you can find 10 scales in error within tolerance all the same direction, you have fine scales and a smooth man. Is not that true?

Mr. Schurte. I have not found any.

Mr. Mineseld. There is difficulty in differentiating between scale tolerances and commodity tolerances.

$\mathrm{Mr}$. BRIGGs. In answer to that the general sentiment has been that when the scale is tested they must use that scale, even if the scale is in error', provided it is within the tolerance. Otherwise you would be involved in tremendous difficulties and could be prosecuted for short weight because of that. It is the only practical way out of the proposition.

Mr. Mikeseld. My whole argument is to make the weighing processes reach accuracy, the primary object. The rest is secondary.

Mr. Schoenthai. Mr. Schmitz spoke of building up weights. Mr. Stewart asked a question after that, and I have no doubt but that there will be some confusion on this proposition. As I understand it, the method employed by Mr. Schmitz is to test the scales with a minimum of 8 per cent test weights and to read the error, then to 
put an equal amount of load on the scales and read the elror on this equal amount; and then again put the test weights on.

It is a common practice, I believe, throughout the country to use an unknown load. For instance, in testing a wagon scale, 1 ton of test weights may be put on the scale, the beam read, and the error noted. Then some object weighing, perhaps, 3 or 4 tons is put on the scale, and to this load are added the test weights and the error then read. Of course the error should be the original error that was found in the original test load. At least I have had that experience.

That practice has existed, and in certain parts of the country exists to-day, and I did not want to get that confused.

The Acting Chairman. I think this amount of discussion excited by that paper is more or less justified, and $I$ think we are all very much indebted to Mr. Schmitz for giving us a clear-cut statement of what the practice of the very best men of the United States is. I am not making that statement in any official capacity. I want that understood.

\section{DISCUSSION ON RE-IYLARKING OF WRAPPED HAMS, BACON, AND} OTHER MLATS.

The Actrng Chairman. I notice that Dr. Alsberg is not here, and we have a few minutes, so I will bring up a matter on this tentative program mentioned to me by $\mathrm{Mr}$. Stewart, and we can have it in mind when Dr. Alsberg is here. It is a telegram of the National Wholesale Grocers' Association of the United States, reading as follows:

NEW YoRk, N. Y., May 22, 1919.

S. W. Stration, Director, Bureat of Standards, Department of Commerce, Washington, D. C.:

National Wholesale Grocel's' Association of United States earnestly requests that you urge convention of weights and neasures officials to adopt resolution requesting Department of Agriculture to provide in new regulations under consideration that wrapped hams and bacon are in package form and must be labeled to slow net weight. Such requirement is in interest of honest weights and measures, is essential for protection of consumer, and necessary to inform purchasing public of what it is buying.

\section{ARJAY DAvies, President. \\ ATFRED H. BECKMANN, \\ Fred R. Draike, Secretary. \\ Chairman Pure Food and Legislative Committee.}

Mr. Hanson. Mr. Chairman, in view of this telegram, I would like to enlighten the delegation relative to a hearing which was held here in Washington some four years ago last March. Previous to that time the Bureau of Chemistry sent out letters, as I understand, to the various States and cities asking them to attend at the bureau's office here for the purpose of giving the bureau some light on whether. hams and bacons should be considered as being "in package form." I am sorry to say that the only gentlemen representing weights and measures officials here were Mr. Tighe, of the city of New York, and myself. There were some representatives, however, from Chicago packers. Outside of these there was not one other person in the United States, weights and measures officials or otherwise, interested enough in the subject to come here and fight for the principle that $155530-20-10$ 
hams and bacons should be within the meaning of the words "in package form."

Mr. FARRELL. The city of New York was suing the packers in the State on that particular matter, and we beat them right at the particular time that that was going on. We were trying the case out in New York City.

Mr. Haxsov. We had the hearing here, as Mr. Farrell remembers. The Bureau was going to defer action. I have written to them a hundred times, and up to the present time they have not come to a conclusion as to whether hams and bacons should be held to be within the terms of the law. In our State we have been successful in prosecution in intrastate business; that is, hams and bacons manufactured in the State must be marked in accordance with the net-weight law.

Mr. Schwartz. I make a motion that this conference go on record, by adopting the telegram itself, that it is the sense of this conference that we are back of this movement to require wrapped hams and bacon to be marked with the net contents.

Mr. Goopwix. I second the motion.

Mr. KeLLY. In regard to this matter, I had a case in court two or three years ago, and it went along for some time. It is my recollection at this time that there were 10 or 12 ounces of wrapping on the ham in this case. It dragged along in the courts until they finally decided that, for sanitary reasons, wrapped hams and bacons did not constitute a package. I have always thought that the decision was not entirely right, and I am glad at this time to be able to second the motion as made by Brother Schwartz, and I trust the conference will make the resolution as strong as possible, and all get together and get behind it.

Mr. Sharp. I have prepared a resolution which is in the hands of the resolutions committee embodying all the facts in the telegram.

The Actisg Chatrian. Could not the resolution committee act on that right now? I don't think we ought to have so much discussion.

Mr. FARReLl. I offer an amendment. New York City is, perhaps, the greatest user of honey in the country.

The Acting Chatriran. Hare Jou considered Massachusetts?

Mr. FarRell. No, sir; Massachusetts for asperity, and New York for sweetness. Howerer, the Bureau of Chemistry has held that the ham was not in package form, but that the comb of honey was.

I would like to offer an amendment to that resolution that combs of honey are not in package form and need not be marked.

Mr. Scrrwartz. I do not think Mr. Farrell understands that we are indorsing the request of the National Wholesale Grocers' Association, who ask that the net contents be marked on hams and bacons. We want to know that these are marked properly. Permit me to straighten this thing out. I think this telegram should be referred to the resolutions committee and for their report later, presenting the proper resolution to enable this conference to go on record.

Mr. KeLLY. I believe this matter is sufficiently important to act on at once, and I more you that the resolution which the gentleman has spoken of be produced, read, and acted on. I think it is perfectly in order to have that resolution.

The Acting Chatrusan. Does the gentleman making the original suggestion, that the matter be acted upon, accept the amendment 
offered by Mr. Schwartz, that the whole matter be referred to the committee on resolutions to be reported on later?

Mr. Stewart. I want to say that the Bureau of Chemistry by its ruling in regard to bacons and hams defeated the case I had against a packer on the question of the marking of meats. We want to go on record right now.

The Acting Chairman. Has the resolutions committee a reșolution prepared?

Mr. Webster. That matter is under consideration at the present time. We have no resolution prepared.

The Acting Chairman. Will somebody state a resolution?

Mr. Sharp. I presented to one member of the resolutions committee such a resolution to-day.

Mr. Houbrook. I have that resolution here. It has not yet been considered by the resolutions committee. I will read.

(Mr. Holbrook commenced reading the preamble to the resolution.)

The Acting Chairman. I do not think we want all this material. We simply want the resolution of the committee. Mr. Holbrook will read simply the resolution proposed to take care of it.

Mr. Houbrook. The whole thing is the proposed resolution. It is in resolution form. If I may say one word here, it contains material which I think perhaps may be resented, and rightly resented, by the Bureau of Chemistry, and I think that very possibly the drafter of that resolution did not have any intention to offend.

Mr. Schwartz. Just take the telegram and use it as the resolution. Have the telegram read again.

The Acting Chairman. [reading]:

National Wholesale Grocers' Association of United States earnestly requests that you urge convention of weights and measures officials to adopt resolution requesting Department of Agriculture to provide in new regulations under consideration that wrapped hams and bacons are in package form and must be labeled to show net weight. Such requirement is in interest of honest weights and measures, is essential for protection of consumer, and necessary to inform purchasing public of what it is buying.

ARJay Davies,
President.
Alfred H. BeckmanN,
Secretary.
Fred R. Drakn,
and Legislative Committee.

Chairman Pure Food and Legislative Committee.

Mr. Howwelc. I think this matter should be referred to the resolutions committee this morning, and they will report to-morrow morn-
ing a resolution embodying the sense of this meeting that we are opposed to the exemption of these commodities.

The Acting Chairman. I might state in answer to that that this conference has just voted to take it up now.

Mr. Holbroor. I may say that at the direction of the resolutions committee a resolution has been prepared, and it is now before me. I have not presented it previously because the resolutions committee had not passed upon it; but if I might read it at this time the committee could decide right now whether they think it a proper resolution to be presented to this conference. The resolution is as follows:

Whereas we, the delegates of the Twelfth Annual Conference on Weights and Measures in conference assembled, firmly believe that wrapped hams, bacon, and other meats as put up by manufacturers are food "in package form" within the meaning of Federal and State laws, and, furtler, that there 
is a real and pressing need for the marking of the net weight in order to put competition on a fair and honest basis in trade and to provide for the protection of the wholesaler, retailer, and consumer from unfair practices and fraud, and to eliminate the confusion arising from conflicting laws; therefore, be it

Resolved, That we emphatically record our approval of laws and rules and regulations to the effect that wrapped hams, bacon, and other meats be required to be marked with the true net weight contained therein, and of the rigid enforcement of the same. And be it further

Resolved, That we respectfully urge the Bureau of Chemistry of the Department of Agricultule to take such steps as may be found necessary to put a marking requirement into effect.

Mr. Sharp. I withdraw the resolution I introduced to make it clear.

The Acting Chatrman. You have heard the resolution read. There is a motion before the house to adopt it. Those in favor say "Aye"; those opposed "No."

(The motion was agreed to.)

\section{ENFORCENENT OF INET-WEIGHT AIIENDMENT TO THE FOOD AND DRUG ACT, BY DR. C. L. ALSBERG, CHIEF, BUREAU OF CHEM- ISTRY.}

Mr. Chairman and gentlemen, some three or four years ago I had the honor of addressing this conference at a time when the netweight amendment, so-called, or the Gould amendment to the food and drug act had only recently been passed and when the action under that amendment was begun. That amendment, as you know, deals only with food in package form.

I would like to-day to give you some idea of what has transpired so far as that amendment is concerned since the last time I addressed you. Under that amendment we have had a great many difficult situations to deal with. The difficulties have arisen chiefly on the definition of the package as that term is used in the law. The first impulse of the committee drawing up the regulations, which was composed of $\mathrm{Mr}$. Fischer, $\mathrm{Mr}$. Halstead, and myself, acting for our respective superiors, was to endeavor to define a package, and we struggled more with that one particular thing, as Mr. Fischer no doubt recalls very well, than with any other matter with which we had to deal in drawing up these regulations. We finally gave it up and came to the point of view that no definition of a package we could make would include all those articles which should be included and exclude all those articles which should be excluded. As a result we made no regulation defining a package, but left the thing to be decided in the individual case, by an administrative ruling, by the decision of a court, or by the opinion of the attorney, and it is on that general basis that we have been proceeding. It is a very unsatisfactory basis, because as yet there have been very few judicial decisions on this particular point. As a matter of fact, although there have been a great many cases brought-and practically all have been successful-under that provision of the law, thele has been to my knowledge no defense raised in any case the main point of which was that the article in question was not food in package form, and therefore not within the provisions of the act. WVe have been proceeding along hoping that we would get a judicial decision. However, in spite of the fact that we are making prosecutions at the 
present time at the rate of 1,000 a year, there has been as yet so few cases in which interpretations of the law have been raised that we have not received any enlightment from the Federal courts on this particular question.

When I state that we are making prosecutions at the rate of $1,000 \mathrm{a}$ year for violations of this particular part of the food and drug act, I do not mean to imply that all the cases are cases in which the violation of the net-weight amendment is the only charge. In a considerable proportion of these cases there are also other charges, charges of misbranding and charges of adulteration under other provisions of the law because, of course the people who are short weighting usually do not content themselres with cheating in that way; they are also often misbranding and adulterating the food. The type of man who will do the one is the type of man who will do the other; so, in a good many of the cases there have been a number of charges. In a measure, that is one of the reasons why relatively few of the cases that we have had so far have been been contested. A man may feel possibly that he is being done an injustice by the charge under the net-weight amendment, but that the charge of adulteration against the goods is a good charge. In such a case he will not defend one charge and have the other proved, but will usually plead nolle contendere to the whole case. A certain number of cases have been of that type. Others, of course, have been straight cases, but I can not say what the proportion is, except that it is a considerable one.

Now, there are just at present certain features of our work which may be interesting to you. We have had a very difficult time as a result of the war with reference to the slack filling of packages; a particularly difficult situation arose, for example, in the spice trade.

Ordinarily, spices are sold for household consumption in 5 and 10 cent packages. In these packages there are usually put 1 or 2 ounces. We have had an exemption of 2 ounces in our regulations, because when these regulations were drawn up some three or four years ago it was not believed that any serious fraud could be perpetrated in a package that weighed only 2 ounces or less. Now, during the war, owing to the disturbed trade conditions, the price of spice has quadrupled in some instances, and the spice grinder has not been in a position to make even a legitimate profit and give the same 1 or 2 onlnces for 5 or 10 cents that he had been giving. What he did was the thing that the average business man usually does. His reaction was characteristic. Instead of cutting down the size of his package and giving a small package, reasonably full, he kept the size of his package constant and filled it only one-half or one-third, or in some cases one-fourth, full. He was not, in a sense, naking any more money by that procedure. He was giving as much spice as he could afford to gire for 5 or 10 cents; but the housewife who was buying a package of cinnamon or a package of pepper, particularly if it was a package with a shaker top attached, undoubtedly was very commonly deceived. Now, according to a strict interpretation of this particular clause of the law, together with the exemptions in the regulations, we could not do very much about the situation. There was no misleading statement on the labels, since they were not branded at all because they were exempt. To rectify this, we hare 
written a new regulation reducing the exemption from 2 ounces to one-half an ounce; so, such packages must now be marked if they contain over one-half an ounce.

This, however, does not help the situation very much. The at. torneys feel that there is no language in our law that will prevent spice grinders from putting onè-half ounce of spice into a 2 or 4 ounce package, even though the package is only a third full, or less, provided they brand it correctly. The average buyer of an article does not know what the relation of the volume to the weight is. The worman does not know, when she buys a small package of spice, whether it would weigh 2 ounces if full or only one-half an ounce. She sees only the outside of the package, and she buys a slack-filled package under the implession that she is getting an old-style full package. It seems very difficult to deal with that particular fraud, which has been, and is at the present time, not entirely eliminated. The attorney's hold that we have no real basis of prosecution under the langurage of the act. The weight is correctly stated. The deception is in putting a stated quantity into an abnormally large package; yet the average woman buys it by the size of the package and if it is a shaker top, she can not open it, and therefore, as a rule, she never finds out that she has bought a slack-filled package.

Apparently there is nothing that we can do with that particular situation under the existing language of our law. We did believe that we could get the shippers of such packages under the provisions of the food and drugs act, which requires that food shall be deemed to be misbranded if it bear any false or misleading design or device. Unfortunately, the word "bear" being used, it seems necessary to interpret it as something on the package, and not the package itself. At least we have run into this particular snag when the matter has been put up to various United States attorneys. A very similar situation exists in the case of canned goods. You can not tell until you open the can whether you are getting a full can or a partly empty one; and the statement of weight on the label of the can means very little to the cousumer. The average woman gauges the quantity of the tomatoes by the size of the can. She will not distinguish between two cans of equal size containing different quantities of food unless she carefully examines the label. These are conditions that do not exist in actual practice. We have here just exactly the same difficulty to meet as in the case of slack-filled spice packages.

We have been able to get at some of these frauds under a clause of the law which has nothing to do with net weight. We have a provision in the food and drugs act that articles are adulterated if any article has been substituted in whole or in part for the article in question in a manner whereby the quality of the package is lowered. Now, in the case of most canned goods, they complete the filling of the can witl a solution of sugar and brine. The can is filled with peas, for instance, and then the interstices between the peas are filled with this solution. They fill the can completely with liquid, because when it is not completely filled the food in the can can not be easily sterilized and it may spoil through scorching. You must have the liquid there so that the heat may have something to conduct it through into the middle of the can, and sterilize it completely. 
Therefore, if we find a can of peas that does not contain the proper amount of peas, but on which the weight is correctly stated, we do not charge that the net-weight amendment has been violated, but that the article is adulterated, namely, sweetened brine has been substituted in part for the peas. We have prosecuted a very large number of cases which are essentially short-weight cases under that clause of the act which in itself has nothing to do with the short weight. This type of prosecution I did not include in my compilation of cases when I stated that we were prosecuting at the rate of about 1,000 cases a year at the present time.

Now, that is all very well when you are dealing with canned peas or tomatoes where they are obliged to put in the water to preserve the goods; but there are some goods that are not put up in that way. For example, shrimp may be packed in brine, and when there are not enough shrimp in the can to comfortably fill it, we can proceed, and have proceeded, in a considerably number of cases, in the same way we proceed against watered tomatoes or peas with large quantities of brine. But it also hapens that shrimp are put up without brine by a special process. It is obvious that in that case we could not get very far along in court, if the weight of shrimp in the can was correctly stated, by alleging that the article was adulterated in that it purported to contain shrimp, but that air had been substituted. So, this roundabout method of getting at slack filling through charging adulteration, whlle it helped us considerably, has not enabled us to deal with all the packages in which short weighing is practiced.

Of course, this canned-goods matter presents a great many difficulties of a technical nature. In the first place, we have to determine how many peas, or how many beans, or how many pitted cherries, for example, ought to go into each type of the sizes of cans for that particular article.

Fruits and vegetables vary widely in their composition. They vary widely, therefore, in their weight per unit volume, and they also shrink in weight in the can during the process of packing, to a greater or less degree. You can not say that the can has to be filled as full of peas as is possible before being sealed and sterilized, because if the peas are rather mature they will absorb water, swell, and open the can. Moreover, you will have a soft mush in the can which looks like a thick pulp, and you have got an article which is not merchantable, an article the public will not accept. There has to be in each such can that is put up a certain amount of head space to allow for the readjustment in volume of the material which takes place in packing, and this head space must be sufficient so that the article will be one which is satisfactory. That does not always mean that the can is to be completely filled. On the contrary, this practice is apt to lead to the rejection of the pack. I well remember a case in which we were called in to arbitrate, in a sense. One of the State food commissioners had caused to be libelled a large shipment of sweet potatoes on the charge that it consisted in the main of decomposed products. The charge was made because the cans were swelled. "Swells" are ordinarily produced by fermentation in the can because of imperfect sterilization or leaking cans, leading to the development of gas. When we came to look into the case, we found that what had happened was that the canner had overfilled his cans; 
had put more sweet potatoes in the cans than was proper, and in the process of cooking the swelling of the sweet potatoes caused the ends of the cans to bulge. They were perfectly good and satisfactory sweet potatoes, but were not merchantable because the average consumer, knowing that the swelled can is usually an unsatisfactory one, can not distinguish between the bulging due to overfilling and bulging due to spoilage and fermentation.

You would think offhand that a given size can would hold more of little fine French peas, than of large mature peas. You would think that the interstices between the small peas would be less than they are between the large peas. Actual experiments show that it is not the case at all. While the small peas can be crowded into a smaller volume, their specific-gravity weight is so nearly identical with that of the brine in which they are camned that they do not actually crowd themselves together in commercial practice to the same extent that the larger and heavier peas do, so that actually you are getting a heavier weight of mature peas into a given-size can. Also, as I have just indicated, the specific gravity or density of the small pea is . different from that of the more mature one. That meant that the Bureau of Chemistry had to undertake, and is just completing after several years' work, a rery extensive, and, I may say, expensive, investigation of the proper fill of the different articles that go into cans for food purposes. We have to go into commercial plants and actually pack under commerical conditions known weights of a large variety of these different articles. Then they have to be stored, because it is a fact that the weight of the solid fruit in the can, the "cutont weight," as the trade calls it, will continue to change for months as the water in the fruit diffuses. Also they have to be shipped around the country under commercial conditions, because a pack of peas originally satisfactory may arrive after shipment in an absolutely unmerchantable condition hecause of having been overfilled. So, we put up thousands of cans of a large variety of products in all sections of the country and ship them from place to place. Then we call in the best experts in the trade, and our own experts also, and at stated intervals after the pack we open them, the final opening being one year after the packing. Of course, we know just exactly how much was in each can. Then the experts, who were the cannedgoods buyers of the great wholesale grocery houses, grade the cans with reference to fill. They grade certain cans as slack, certain cans as satisfactory, certain cans as ideal, and certain others as overfilled. They did not know how much went into them, but it was strange how uniformly they check each other. Some of the people who have been making a practice of handling slack cans practically convict themselves when they are judging samples of that kind.

On the basis of these findings, which are really based on the judgment of the trade, as well as our own, we are publishing what we believe to be the proper fill for the various sizes and types of cans for the various kinds of goods. We have already published these data on cove oysters, shrimp, pitted cherries, beans. string beans, peas, and several other articles, and we expect to get the full line out and published for the information of the trade a month ahead of the packing season for each class of fruits and vegetables this year, so that the trade will have a month's notice of the figures. 
The trade in general has cooperated with us in this particular matter exceedingly well, and they are adopting. and have been adopting the standard fills which we are proposing as their standard for their commercial transactions. We have already standardized a number of food packages, even though under the net-weight clause of the food and drugs act we might not be able to prosecute a man for slack filling, and wc have been getting cooperation from the industry along these lines.

The situation, as you see, with reference to these slack-filled packages is really an anomalous one. We are doing a thing that was intended to be done under one clause of the law, so far as we can do it at all, under an entirely different clause. We are at the present moment preparing an amendment to the food and drugs act which will be presented to Congress within a very few days. We are going to ask Congress to amend the food and drugs act so as to give us direct power to suppress these practices of slack filling. We have succeeded in cutting it down very considerably, but not in suppressing all lines as we ought. I do not know whether Congress will at this time find an opportunity to consider and pass such an amendment, but the fact that the packer is given an opportunity to slack fill a package, or put in a false bottom, or leave an unfair amount of head space, providing he declares correctly on the label how much food is in the package, is a very important and a very serious situation, because the average consumer does not know how much the food should weigh. They buy their food in package form by the size of the package, and our experience is that the declaration of the label on the outside does not prevent imposition on the consumer. It shows only if he has got two packages side by side for comparison, one of which is honestly filled and the other not and both with the correct weight stated. That very rarely happens.

Of course, you gentlemen recall that our act has jurisdiction over only interstate shipments. The violation of this law is not, technically speaking, in the adulteration or misbranding of food. The violation is the shipuluent of such misbranded or adulterated packages in interstate commerce. The crime is committer, if crime be committed, at the time when the goods are shipped or offered for shipment in interstate commerce. It therefore becomes incumbent upon us when we make a case for violations of the net-weight amendment to prove that the goods were in violation of the law at the time they were offered for shipment or shipped in interstate commerce. That means we can not consider, so far as our law is concerned, shrinkage occurring after shipment. Shrinkage before offering in interstate coumerce is no excuse under our law, but shrinkage after shipment constitutes a defense. Therefore, it is exceedingly important that you and the Bureau of Chemistry cooperate completely in this matter. It is beyond our power to protect the ultimate consumer from being takell advantage of because of this shrinkage. That is your job, not our's. We wish it were, but it is not. However, if our powers did extend to that point there would not be any particular work for you gentlemen to do in this particular line.

Now, the fact that we have to deal with the condition of the goods when they were offered for interstate shipment or actually shipped makes our problem a great deal more difficult than your problem. You have to make sure that when a man buys a pound of cheese he 
gets a pound of cheese. We can not be present at the shipment of all the goods that go into interstate commerce. We find that a shipment of cheese which has been on the road a month is short weight. We can not charge that that shipment constituted a violation of our law unless we can prove that the cheese must have been short weight when it entered into interstate commerce. This means that the Bureau of Chemistry, in addition to making such investigations as these slack-filled investigations for canned goods, has found it necessary to make a great many investigations of shrinkage of such articles as cheese, macaroni, fruit, and vegetables. A characteristic example is an investigation that we made last summer of the shipment of grapes from a certain section of western New York to other parts of the country. Our inspectors weighed the grapes and measured the baskets as they arrived, and we found very shortly that there was a violation of the standard basket law. Of course, we reported this to the Bureau of Markets, which has charge of the enforcement of that law, and a prosecution resulted, but we also thought there should be a prosecution under the food and drug law, that the shippers in question should be punished under that act. We were immediately confronted with the question of what is the shrinkage of grapes in certain shipments, as from western New York to Baltimore or to New York City. That necessitated that we send a group of men into western New York who would actually put up grapes in baskets at different times of the season, at different stages of maturity, because the ripe grapes will shrink more than the green ones, and determine the minimum and maximum shrinkage for grapes recently packed and recently shipped. We have that data now. Last season we could only make a few prosecutions for violations because we had only sufficient evidence for extreme cases. Last year we obtained the data which will enable us to prosecute people for short weight on shipments of grapes. The same is true of cheese and of macaroni, and of a whole series of other products. All that information is, so far as we have it completed, at the service and disposal of you gentlemen if you are interested or if it will be of any service to you. We have hesitated to publish a great deal of it, because we have not wanted to give to the food shippers information which might enable them to sail closer to the line than probably they can sail at the present time. Our experience in the enforcement of the food and drug act is that establishing tolerances and standards, and making them publicly known, often has very bad effects. I can cite as an instance the case of black pepper. It has nothing to do with this net-weight matter, but it illustrates what I mean. Many years ago we had in the Department of Agriculture a national foodstandards commission, created by act of Congress.

Among other things that commission established standards for ground black pepper. Their standards consisted in declaring what was pepper and what were its limits of composition. Now, of course. they had to take the position that any kind of pepper which was pure was entitled to be called pepper. Some years ago, the pepper crop in Malaysia, Java, and Sumatra had a bad year, and during that bad year there were perhaps 20 per cent of berries that did not plump out. We have the same thing in wheat; in some localities wheat does not plump out; it shrivels and is inferior. In these cases the pepper berries are hollow and have no inside, and consist in the main 
of shells. If you grind that kind of pepper berries there is a large amount of shell, and the crude fiber content is high. It is honest pepper, but poor quality. It is not adulterated pepper; it is the ordinary run of pepper for that year, and obvionsly a standard made for pepper must permit that particular pepper to be marketed. Yet: such pepper may contain 15 per cent crude fiber, the material that characterizes the shell. What has been the result? Pepper shells are on the market in Europe, being obtained when white pepper, which is hulled black pepper, is manufactured. Of course, the shells are worth nothing, and can be bought for from a fraction of a cent a pound to 2 cents a pound delivered in this country. For years certain manufacturer's who employed good chemists have been getting batches of fine-bloom, high-ground pepper containing only 9 per cent crude pepper. They grind in with this perhaps 6 per cent of the pepper shells which they have bought, and produce an article containing not more than the limit of 15 per cent of cride pepper, which the food standards committee has held is the maximum content that any pepper ever has. So, you will see why we are very loath to publish numerical figures, because they are apt to give the crooked man a formula for conducting his crooked practices within the limit and range within which they may be conducted. If some of you are impatient that we have not published anything in the line of tolerances, that information is at your service as officers; but we do not like to put it at the service of Tom, Dick, and Harry, who may put it to dishonest uses.

I think that covers, Mr. Fischer, some of the things I wanted to present. If I seem to present mainly matters of difficulty, that is, I think, what almost everybody experiences when they have a new law to enforce which is, very complex in its bearings. The difficulties in the beginning loom up prominently, but we are going on at what seems to us a pretty good gait, and have made great progress during the last two years.

\section{DISCUSSION OF ABOVE SUBJECT.}

Mr. Schwartz. Mr. Chairman, will Dr. Alsberg submit to some questions at this time. We want to get a little discussion on this container law. I was much interested in the Doctor's talk and in his asking for the cooperation of the several departments of weights and measures, but he does not give us any solution as to how we are going to cooperate. In our State we have practically adopted the pure-food net-container act and made it a part of the State legislation of New Jersey, and we have met with some difficulties in it, as Dr. Alsberg has in his investigations. One of the things in which at this time we are very much interested, and I think Pennsylvania is also, is that relating to the measuring of cans. Section $(g)$ provides that "the quantity of the contents shall be stated in terms of weight or measure unless the package be marked by numerical count, and such numerical count gives accurate information as to the quantity of the food in the package."

Coming down to $(l)$, "when a parkage is not required by paragraph $(g)$ to be marked in terms of either weight or measure, and the lunits of food therein are six or less, it shall, for the purpose of 
this regulation, be deemed 'small' and shall be exempt from marking in terms of numerical count."

Of course, these regulations, I find, were issued by your departinent.

Dr. Alsberg. By the three departments.

Mr. Schwartz. By the three secretaries. In Philadelphia, Pa., and in New Jersey we have two baking concerns that put up cakes in small packages and place these in a large carton, which is sealed. Sometimes on the botton of the carton the arerage weight is stated as 2 pounds. Now, under your regulations as I understand them, since the weight must be conspicuously placed it should not be on the bottom of the carton. Now, when the original container is opened and the flap turned up, there is seen an adrertisement of the brand. In the one case there are five small packages wrapped and not marked, each weighing 4 ounces or more. Sometimes the arerage weight of that package is placed on the bottom. In the other case, they have six cakes to the package weighing about 10 ounces. The question I want to ask the Doctor is, What regulation applies, if any? Ought not each small package be marked with its net weight?

Dr. Alsberg. You have asked me two different questions, and I will take them up separately. In the first place, you want to know how you can cooperate with us. Well, when I came into the bureau I found that there was no machinery for cooperation between State and municipal officials. After casting around for a while to determine how re could get some cooperation I decided that the only way to get anything done right was to get a new man and make that his job. So. we established in the bureau an office of cooperation, and I called to take charge of that office of cooperation Mr. J. G. Abbott, then the State food commissioner of the State of Texas, and an efficient one. He came to us four or five years ago, and it is his job to see that every food or drug officer or sealer of weights and measures who wants help or information gets it. That is his sole job, going around and visiting them and helping them in their difficulties and keeping them in touch with us.

Every such inquiry that comes to the bureau, no matter what its subject matter nay be, goes to Mr. Abbott. It does not go to the man who has charge of the subject. He or one of his assistants wets the information and handles it himself. The best way of getting in touch with the bureau is to get in touch with Mr. Abbott. Anwther way is keeping in touch with on local offices. I do not know whether in the State of New Jersey the net weight work is tied up with the work of the food and drug commissioner.

Mr. Schwartz. No; in the next year after the act was originally passed (in 1915-16) the act was attached to our weights and measures law.

Dr. Alsbers. Then, in your case the matter is relatively simple. I do not know whether the gentlemen who have to do with the enforcement of the local laws know that the Bureau of Chemistry maintains 18 branch offices which have to do with the enforcement of the food and drugs act. We have, in addition to that, a number of research laboratories scattered over the country. We have 18 branch offices whose sole job it is to enforce this law in their respec- 
tive districts. Some of these branches are located at Boston, New York, Philadelphia, Baltimore, Buffalo, Cincinnati, Chicago, Minneapolis, St. Louis, New Orleans, Savannah, Denver, Seattle, and San Francisco and in Porto Rico. The men in charge at these stations have authority and instructions to cooperate with all local officials. In your particular case the simplest thing to do is to get in touch with the man in charge in New York or in Philadelphia, and work with him. They can notify you of interstate shipments in violation of the law that are going into your territory and will be glad of information concerning shipments out of your territory into some other State that are in violation of the law. You will find the New York laboratory situated in the United States Appraisers' Stores, Washington and Christopher Streets, and the Philadelphia headquarters is in the old customhouse on Front Street. Within easy distance of pretty nearly every one of you there is a branch office of the Bureau of Chemistry, with a man who has instructions to cooperate with the local people and to assist them in every way he can, and that is the way in which cooperation can be handled.

So far as the marking of the package of food is concermed, that is really a shipping case which contains inside of it a number of smaller packages. We have held that under the provisions of the law a statement on the outside of the case or package of the number of units inside the package is no indication of the quantity of the contents of food inside that package, except in that particular instance in which the name of the article implies a certain size. We have not required or allowed, for example, a declaration that the contents of a box of apples were 160 apples without any further description. We have insisted that such a shipping case be labeled $1 \frac{1}{2}$ bushels, or whatever it may be, or so many pounds; but if they want to say 150 apples of an average diameter of $2 \frac{1}{2}$ inches, if that happened to be the size, it would be all right. But to say 150 apples obviously does not tell you what measure of food there is in the package and therefore does not comply with the requirements that the quantity of contents be stated.

In the same way we have not permitted-and nobody has tested our refusal in court-a man to pnt into a shipping case a lot of small packages and label that shipping case as containing 100 packages of cake. If he wants to label them by numerical count he can say 25 pounds of cake, or 25 one-pound packages of cake, and we require in a case of that kind that the individual 1-pound packages also be marked. That is the way we have handled that particular situation.

Mr. Schwartz. Another question: Suppose the packages of food are six or less. Could these people put in five packages weighing 4 ounces or over and leave the individual packages unmarked if the carton is marked with the total weight?

Dr. Alsberg. Have you an exemption size of 4 ounces?

Mr. SchwarTz. No; we have your exemption.

Dr. Alspera. We have lowered that to one-half ounce. The individual package is not exempted.

(At this point, Mr. Webster, of New Hampshire, assumed the chair.)

Mr. Mrkeselu. I would like to submit this label to Dr. Alsberg and ask him if this marking is in violation of law. Does that comply with the regulations of the board? 
(The label referred to bore the following wording in 8-point type, under the word "Directions":)

Guaranteed genuine and unadulaterated. No preservatives or artificial coloring used.

Net weight, 11 pounds, equals about 19 pounds fresh rhubarb.

Soak rhubarb in cold water, etc.

The Acting Chamman. The expression of net weight is a part of the advertisement.

Dr. Alsberg. We should not consider that as plain and conspicuous.

Mr. MrkeserL. Then it is a violation.

Dr. Alsberg. I should say it is a matter of opinion what is plain and conspicuous. We think the statement of the quantity of contents should be made by itself. We have fixed no definite size of type or definite color, but the language is that the label shall be plain and conspicuous. When the net-weight requirement went into effect, there were some bottles on the market which had been packed without being marked. They put a sticker or label around the neck printed in large letters, giving the contents. That certainly was more conspicuous than if they had it printed on the principal label.

Mr. Mrkesell. In your judgment, that is not a proper net-weight marking?

Dr. Alsberg. We would hold it a violation of the law because of its not being plain and conspicuous.

Mr. Mrkeselu. Should it be prosecuted, and how?

Dr. Alsbera. Any United States attorney or any local attorney could prosecute. We could prosecute this particular case if it was shipped in interstate commerce.

Mr. Mrkesell. In the course of your address you spoke of standard containers for the canning of fruits and vegetables. Are there certain containers which are standard?

Dr. Alsberg. I meant standard in trade. There are no standards fixed by law for packages or cans. That is a trade question.

Mr. Mrkesel. Your department issues a regulatory bulletin. Would there be any objection to your department sending that bulletin to all these gentlemen?

Dr. Alsberg. No objection, and we will be glad to do that or anything else we can to assist you or to have you assist us.

Mr. Mrkesen. I have been on the job in my district five or six years, and during the whole of that time I have received your bulletin and find it of inestimable value, and I think all these gentlemen would find it so.

Dr. Arsberg. If anybody will send in his name and address, why, of course, he would be put on the mailing list for all our material which might be of interest to him. You gentlemen may change your particular jobs, come into office and go ont of office, but we have not been able to keep track of you.

Mr. Mrkesenc. If you please, I suggest that the bulletins be addressed to the department and not to the individual; then it would not be necessary to make any change whatever. As long as the department existed the bulletin would be delivered to the commissioner or sealer.

Dr. Alsberg. We carry such a list of all the food officials. I wonder whether there would be any object in adding to that list the names 
of all these men. We have this list of food commissioners, State commissioners, and inspectors of foods and drugs, and keep it up to date. Probably we really ought to add to it the sealers of weights and measures, as they all have to do with food.

Mr. Tighe. Dr. Alsberg said that he conferred with Mr. Fischer and Mr. Holbrook with reference to wrapped meats and that all three gentlemen were unable to arrive at any definite conclusion as to whether or not wrapped meats came within the meaning of the words "in package form."

Dr. AlsBerg. No; my reference in my opening remarks was to the original regulations. The act required that the Secretary of the Treasury, the Secretary of Agriculture, and the Secretary of Commerce should draft appropriate rules and regulations for the enforcement of the act. The Secretary of Agriculture delegated me to represent him, the Secretary of Commerce delegated Mr. Fischer, and the Secretary of the Treasury delegated Mr. Halstead, head of the Division of Customs in the Treasury Department, which, of course, is interested in weights and measures from the standpoint of collecting duties on imported articles, to represent him. The three, with the assistance of their respective solicitors, prepared the original draft, which went to the three secretaries for their approval. At that time the law was not yet operative and no question in reference to ham or bacon was in their minds at that time.

Mr. Tigre. May I ask further if in this power to regulate slackfilled packages you contemplate incorporating the power to regulate the sale of wrapped meats and a statutory definition of the words "in package form"? Does the bureau contemplate incorporating. that?

Dr. Alsberg. We were not contemplating a definition of a package because we are at a loss to know what definition would cover all cases without including some cases that obviously ought not to be included. We were not proposing at this time to deal with anything except the slack-filled cases.

Mr. Tigre. Do you not think, Dr. Alsberg, that the abominable practice of selling wrapped meat is such that there should be some definition of the package?

Dr. Alsberg. If we could get a statutory definition of what a package is, I should be very happy, indeed, because it would immensely simplify the operation of the bureau.

Mr. Tighe. Could not your bureau specify that in its regulations just as was done in New York.

Dr. AlsBerg. The attorneys have held that we have not been given the power to do that. I have no power to say what a package is. We can not make a thing a package just by saying so.

Mr. Trghe. It would appear to me that the commodity known as wrapped meats has a practical exemption from the regulations of the Bureau of Chemistry of the Department of Agriculture in view of the fact that you are unable to define a package in relation to the sale of that particular commodity. That is what this conference is very deeply interested in.

Dr. A LsBerg. I am also deeply interested.

Mr. Webster. Mr. Fischer has asked me to serve as temporary chairman. It was voted some time ago to resolve ourselves into an 
open forum after Dr. Alsberg had completed his address, and if that is the wish of the conference we shall proceed along these lines.

Mr. Strewart. I would like to have two things brought out. One of them is, I would like to have the resolution that was adopted here this afternoon read, so the Doctor could hear it. Then I would ask this question: I understand the district attorney will assist us in the preparation of these cases. We have had two carloads of tomatoes tied up in the city of Huntington for two years, marked 2 pounds net, shipped from the State of Virginia into the State of West Virginia. They do contain about $1 \frac{1}{4}$ pounds net. The case was turned over to the district attorney in the city of Huntington at the time. I have visited him a number of times since and there has been no action taken.

Dr. Alsberg. Local attorney or United States attorney?

Mr. STEwarT. The United States district attorney.

Dr. Alsberg. If you will give me the data of that case-who libeled these tomatoes?

Mr. Stewart. I am not able to-I do not have the data here, but the city sealer held them up and turned the case over to me as State inspector. They are still tied up, and I do not propose to allow them to be sold. I certainly would like to have some one take some action.

Dr. Alsberg. If you will write me a letter, giving me the data, I will see what can be done about it. As far as I know, the Bureau of Chemistry has no knowledge of that particular case. There may be something in the files. You have never taken it up with us?

Mr. Stewart. No, sir; we turned it over to the United States authorities and they promised to do something.

Mr. Irvine. Mr. Chairman and gentlemen of the convention, one of the questions that is paramount with me is the question of standards for food packages. This is a question that has been discussed considelably out West and one that I believe every consumer in this land is interested in. This is one of the questions that I was requested to bring up here or to take part in the discussion if discussion was had. I would feel that I had not done my full duty should I not mention it or take some part in this important discussion. It seems to me that every part of the discussion here confirms the idea we have out there that food packages should be standardized. The Doctor has told us about the packing of spices in cans that, perhaps are made to contain 4 ounces, but which contain only an ounce or 2 ounces. He says this is probably done by the honest manufacturers, the packers, because of the increased cost of the product. I hardly agree with him relative to the honesty of the packers. If the packers who do that were honest, they would cut down the size of the package, so they would not mislead the housewife when she purchases the package.

Now, you find packages of food products marked 11, 12, and 13 ounces that seem large enough to contain a full pound. You find packages marked 1 pound 12 ounces or 1 pound 10 ounces that would contain fully 2 pounds. It seems to me that if this conference will go on record as favoring the standardization of packages of food products and can furnish sufficient punch to force some legislation along that line, we will be doing the people a great service. The in- 
clination on the part of the packers to trim down the size of the package for the purpose of profiteering seems to me to be so great that it is a question which concerms every person interested in weights and measures work. I think we should go further than that. We should require that mill products be packed in 100-pound packages and subdivisions of 100 pounds, and even further than that, and require that a moisture content be established and the shrinkage determined according to the proper percentage of moisture in the mill product when it is put up under favorable circumstances. Some time ago I discovered 97 bales of corn meal each containing 10 bags marked 9 pounds, and practically all of them were $7 \frac{1}{2}$ per cent short. A few bales ran $5 \frac{1}{2}$ per cent short. I got into communication with the Federal representative in Denver, and we made an investigation, weighing up a large quantity of it and obtaining a good average of the shipment. It was his opinion that there was a great amount of shrinkage. I turned it over to him, and a month later learned that he had submitted the question to Washington and that the corn meal had been turned loose because they could not prosecute.

It seems to me that the standardization of food packages is a proper subject for this conference to take up, and I hope that the resolutions committee will draw up a resolution memorializing Congress for the enactment of a law to standardize packages of food products. 1

Mr. Stewart. You will note on the program a paper on "Mine Scales," and I would like to see this paper before this convention.

The Acting Chairman. If that is the sense of the conference, we will be glad to hear from Mr. Harrison.

IMINE SCALES AND MINE-SCAIE INVESTIGATION, BY M. J. J. HARRISON, BUREAU OF STANDARDS.

The Bureau of Standards commenced the work of testing mine scales about one and a half years ago, when the State's attorney of Allegany County, Md., came down here with a personal appeal to this Bureau to come up and settle some disputes in his county pending at that time. He said the situation existing was a very critical one and that there was nobody there available who could settle it in any way. So Mr. Holbrook and another man from the Bureau went up and made an investigation. As a result of what they found, the next Congress gave us an appropriation for the investigation of mine scales and weights, the methods of using and determining them, and the general conditions existing in regard to the accuracy of weights and measures. at the mines. We at once started out to get equipment to take up this work. We found that the most practical way of doing it was by employing motor trucks. Consequently, we procured two motor trucks, equipped them, and started out. Up to the present time we have made additional inspections in Maryland and carried the investigation into five other States.

We have not as yet made any detailed study of the conditions in any given State, simply because we have not had the opportunity. All you gentlemen will realize that to make a detailed investigation of even one State takes a very considerable time, and we have really 
just touched the high spots so far. The places visited and the cases investigated have been selected on the strength of information supplied to the Bureau inspectors or to the State or county officials who passed it on to the Bureau, or in other cases upon request made by miners' organizations or by coal companies. There have been about 200 individual cases investigated; but, as I said before, in only one instance has any return trip to a district been made. That was in Maryland. When we got back there the second time, we found a very decided improvement in conditions. On the first inspection trip the average error of all the scales tested was about 6 per cent in favor of the operators. When we went back there, we found that everybody along the creek had been hiring scale men in the meantime. Nobody told them to do it; they just got out and did it. During the second inspection we selected scales in exactly the same way that we selected them the first time, yet the average error in this case was only seventeenth-hundredths of 1 per cent, as contrasted with the former error of 6 per cent.

I have been asked by one or two of the gentlemen here, interested in this question, to outline the methods used in testing these scales. The equipment that we have in each truck consists of a ton of 50pound test weights, a smaller number of standard counterpoise weights, a balance, and other necessary equipment.

When I say a ton of weights, I mean the ton used in the State in which we are working. If we are working in a State where the ton of 2,240 pounds is used, then we use this amount of weights; if in a State where the 2,000-pound ton is employed, then we use 2,000 pounds. We also test scales with loads of one-fourth ton and onehalf ton. The reason we use 1 ton of welghts is becanse it is not practicable, so far as we have found, to carry a larger quantity; if it were, we would use a larger quantity.

We test the beam indication, each counterpoise weight, the multiplication of the scale, and the sensibility reciprocal at various loads.

We take the attitude in testing scales that you should test it to capacity load as nearly as possible. When you have a 5-ton scale, however, a test at capacity would require the employment of 5 tons of test weights and hauling 5 tons of test weights around the country is not a simple proposition. A great many of the mine scales of the type upon which we have been working are locally tested with two 50 -pound weights, or with four or five or occasionally with ten 50pound weights. We do not believe that you can get a representative test of the performance of any mine scale by using less than 2,000 pounds. In effect we actually use more than 2,000 pounds, since after we have gone up to 2,000 pounds we take a mine car, determine its weight, place all our test weights in it, and then use this as a test load in different positions on the platform. This method is employed in the case of a platform scale, and about one-half of the mine scales so far encountered have been of this type. In some cases we have gone further than that and substituted for the test weights in the car a quantity of coal, or car wheels, or some other heavy material, building up to the same weight. Knowing the weight of this load, we then add our test weights to it. Our known load will thus run up to $2 \frac{1}{2}$ tons, perhaps, which is a good working load for most of these scales. The only objection to this method is that you must be very careful in 
taking your observations while making these different substitutions, if errors are to be avoided. The accuracy of this method depends also upon the sensitiveness of the scale. If very insensitive, it is of no use to do it at all, because the sensitivity of the scale is the measure of how close you can weigh with it, even if it is correct in every other way.

We have found several cases where the scales were almost right except that they showed no evidence of ever being intelligently balanced. The out-of-balance condition was anywhere from 10 up to 600 pounds. It may seem absurd on the face of it to say a scale 600 pounds out of balance was in use, but that was the actual condition in one place the first time the Bureau men went into Maryland. In this case the scale was equipped with a spring dial attached to the end of the beam. They balanced the scale very carefully every morning, but when they balanced it they took off the counterpoise hanger from the end of the beam. After the scale was carefully balanced they hung that on again, thereby throwing the scale out of balance by the weight of that counterpoise, which represented 600 pounds. Then they used the scale in that way. They knew something was wrong with it, because most of those weighmasters can judge the weight of a carload of coal with fair accuracy, but they did not know what the trouble was in this case. So they were accustomed to allow the cars to come down on the scale with considerable speed and impact and as the needle responded they would take the farthest point it reached and call that the weight of the car. Of course, that varied with the speed of the car and the particular way in which it hit the scale.

We have issued several communications on the maintenance of mine scales and we are preparing a set of specifications for the construction or manufacture and the installation of mine scales. We hope to get this out very soon now, and we hope for considerable cooperation from the manufacturers and from the people who are buying the scales.

I have not as yet said anything about the tolerances which we apply to these mine scales. The tolerance for platform scales as given in Bureau of Standards Circular No. 61 is two-tenths of 1 per cent, or 2 pounds in 1,000 pounds. That is the tolerance which is applied to railroad-track scales and to wagon scales and platform scales in general.

Now, there is no fundamental difference in the construction of the lever system of mine scales and wagon scales. However, there is a fundamental difference in the uses to which they are put. It seems to me that what is being bought over a mine scale is labor. What is being bought over the railroad-track scale on which coal is weighed is the coal itself. The price of labor to mine a given quantity of coal is very much less than the price of the coal itself, and for that reason we feel that the tolerance on the mine scale need not be as small as the tolerance allowed on a railroad-track scale. We have felt that a tolerance of four-tenths of 1 per cent, or double the tolerance applied to the railroad-track scale, is a proper tolerance for the mine scale.

Another problem with which we have had to contend and to which we have given considerable attention is the tare weights of 
the cars used in the case of the platform mine scales. There are a number of States that have attempted to govern the question of the tare weight of the mine cars by a legislative act. I would not say that any of them have been very successful in doing that. There is only one State, so far as I know, whose law says that the weight of each car shall be used in determining the amount of coal in the total load. In other words, this State requires the use of actual tare weights. It is the almost universal practice to use the average tare weight. Now, the usual manner of getting at that is for the people concerned to weight about 10 per cent of their cars and call that an average of all of them. This is absurd on the face of it, and we have proved this in sereral instances. The view of the Bureau is strongly to the effect that the actual tare weight should be used instead of the average tare weight. We have not found any advantage in the use of the average tare weight, except that using the actual tare makes a little more work for the weighmaster, a little more clerical work in between times when he is not weighing anything. We have found some instances where theoretically the scales were balanced to fit the weight of the average car used. I mean by that that the scale with the platform empty is out of balance by the amount used as the average tare weight. The idea is that when they run the car on and take a weight this is the actual weight of the coal as indicated by that scale. As a matter of fact we have not found a single instance where that practice was employed in which they had the balance correct. They thought they had, but it varied anywhere from 50 to 100 pounds from the supposed balance, and. consequently, there was a constant error of that much on every car of coal that was weighed on the scale.

There are a number of points that come up along these lines, and I have outlined a good many of those which are of more general interest. I know that you want to proceed with other work; so I think I will close to let you do so.

\section{DISCUSSION ON ABOVE PAPER.}

The Acting Chatruan. I believe we go into open forum at this point.

Mr. Fischer. I understood Mr. Harrison to say that the reason for increasing the tolerance was the low price of the commodity, but I think he overlooked the fact that on account of the rough conditions which exist we also find it impossible to require greater accuracy. It would have been impossible to maintain scales within these small tolerances that we have for our other scales, anyway. As a matter of information, I would like to have Mr. Harrison make a statement as to how the tolerance affects the wages. Have you made that computation-the effect of the errors allowed on the actual wages of the miners? My recollection is that it is a very small matter.

Mr. HaRRison. I am very sorry to say that I have not these figures with me, and I would not assume to give them offhand.

Mr. HoLbrook. I think I can give them offhand. The average amount paid for digging coal is about $\$ 1$ a ton, 100 cents for 2,000 pounds, or 1 cent for each 20 pounds. The error per ton now allow- 
able is 8 pounds, and, therefore, it would seem to make a difference in the wages of the miners of eight-twentieths or 0.4 of a cent per ton; less than half a cent per ton.

Mr. Mrkiseld. In reference to the Georges Creek field, am $I$ to understand that the miners and operators work on a "50-50" basis? Anything past 50 pounds is credited as 100 pounds; anything less than 50 pounds is not credited at all.

Mr. Harrison. That is almost universal, not only in the Georges Creek field, but in almost all the other fields.

Mr. Mrkeseld. Naturally, they do not grasp that the accuracy of the scale has anything to do with the 50-50 basis. If the scale is incorrect to the extent of 2 or 3 pounds, when the 50-pound point is reached, one side loses and the other side gains.

Mr. Harrison. They feel that a small error in the scale does not make much difference; but this it not true. Suppose they have a 10-pound error in the scale and they are giving and taking on 50 pounds. Four-fifths of the time that error of 10 pounds in the scale would make absolutely no difference whatever in the weight that the miner would get the credit for, but the other fifth of the time it would make a difference of five times the amount of the error. Because the 50 pounds is so much larger a quantity than the 10 -pound error, he does not pay much attention to the 10 pounds until the matter is explained to him.

Mr. Mikeselu. I have in my hand a copy of a statistical report that we fill out when making a test of a mine scale, also with it a card containing information given by the Bureau of Standards which $I$ have taken from some of their pamphlets. I have here another slip with certain questions on it which is sent out in advance to each coal company for the purpose of getting data on each scale. All the companies readily fill these out and return them. Another card is filled out and left with the weighmaster advising him to let us know when anything is wrong, or whether adjustments have been made. When we get back in that section, the scale is retested. The reason we leave this is for the purpose of getting the owner to readjust his scales whenever anything goes wrong with it.

Mr. Stewart. Mr. Harrison, we find in the mining districts scales having a net weight and a gross weight beam; that is, the upper beam will be gross, the lower one net. They weigh the car to take the tare on the net-weight beam. They weigh the whole load on the gross beam, thereby entangling the two. I want to know if you have found anything of that sort?

Mr. Harrison. We found some instances where, as you say, the car was weighed on the net-weight beam, the average tare set off on this beam, and no more attention paid to it. The coal was weighed on the gross-weight beam, and with counterpoise weights. Does that answer your question?

Mr. StewarT. No; my point is this: The beam is graduated to 1,000 pounds. The cars may weigh 2,200 pounds. The counterpoise weights are all gross. They put on a counterpoise weight and then complete the weighing on the net-weight beam, mixing the two systems together.

Mr. Harrison. Mr. Stewart, it is my understanding that you use the 2,240-pound ton. 
Mr. Stewart. It has been used until I had passed a recent act making it 2,000 pounds in the State of West Virginia.

Mr. Harrison. In that case you are all right, and in the other case I do not know of any way to simplify the matter except by the use of net counterpoise weights, which are employed in many cases.

Mr. Stewart. I understand that the same practice is being employed in Ohio and Pennsylvania.

The Acting Chairman. The chair notices that the secretary is in the room and will be very glad to be relieved of his duties.

(At this point, the secretary, Mr. L. A. Fischer, resumed the chair.)

\section{ELECTION OF OFFICERS.}

Mr. Hanson. In view of the fact that a great many of the delegates will leave to-night, I have been asked by several if it would be possible to have the election of officers this afternoon instead of tomorrow morning. Therefore, I ask you whether it is the wish of the conference that we proceed with the election of officers at this time instead of to-morrow. The committee on nominations is ready to report.

The Acting Chalrman. Do you make that as a motion?

Mr. Hanson. Yes, sir.

(The motion was seconded and agreed to.)

Mr. Schwartz. Before the chairman of the committee reports, I would like to state the following recommendation of the committee: Your committee on nominations respectfully recommends that the office of second vice president be created and that nominations for this office be made from the floor. I introduce that as a recommendation of the committee.

Mr. FINE. I move you that the recommendation be accepted.

Mr. Goodwin. I second the motion.

The Acting Charrman. Gentlemen, you have heard the motion that the office of second vice president be created. I think that that is a good idea. We should not go too far in the creation of offices.

(The motion was agreed to.) REPORT OF COMMITTEE ON NOMINATIONS, PRESENTED BY A. W.
SCHWARTZ.

Your committee on nominations respectfully recommends the following names for officers of the conference for the coming year:

For president, S. W. Stratton; first vice president, Charles G. Johnson; secretary, L. A. Fischer; treasurer, Frank Wanser. For the executive committee, ex officio officers: W. F. Steinel, Charles C. Neale, W. T. White, W. F. Cluett, F. W. Tucker, F. L. Woodworth, D. A. Gregg, H. A. Webster, T. F. Egan, J. M. Mote, Anton Runbeck, T. L. Irvine, J. J. Holwell, T. F. Mahoney, R. W. Smith, G. B. Stewart, F. G. Barnard, O. E. Mikesell.

Mr. Mrkeselu. Is it in order to make a nomination for second vice president?

The Acting Chalrman. It seems to me we should dispose of the regular nominations first.

Mr. Mrkesert. We could dispose of them all at one time. 
Dr. Reichmann. Is there any particular number provided for on the executive committee?

The Acting Chairman. I think there should be 17.

Dr. ReICHMaNN. Is the executive committee increased over last year?

Mr. Hanson. The officers are understood to be members of the executive committee; for that reason we arranged them geographically, so that there will be a representation throughout the United States.

Mr. Horвrook. There were 17 members of the executive committee, inclusive of the president and secretary. The treasurer and the vice president have not been nembers of the executive committee heretofore. That was provided for by a former resolution of the conference.

The Acting Chalrman. You say that that was done by resolution? I imagine we should rescind that action by a separate motion rather than to do it automatically by electing this committee. However, I have no choice in the matter myself. I will be very glad to entertain a motion as to how that matter shall be disposed of.

Mr. Fine. Does it make any difference? We have no constitution or by-laws.

The Acting Chairman. We want to do things in an orderly way.

Mr. Schoenthal. I think if the records of the last convention, held at the Raleigh, were read it would show that this committee was increased from 15 to 18.

Mr. HoLrRook. There are now 23 names in nomination for the executive committee. It was not increased up to this number. No suggestion has been made that it was increased to this number.

Mr. J. T. Townsend. We had 17 on the committee last year, counting the president and secretary.

The Acting Chairman. Is it the wish of this conference that the number be increased?

Dr. Reichmans. I move that the previous resolution be rescinded and the number increased to whatever the nominating committee may report.

(The motion was seconded and agreed to.)

The Acting Chairman. Instead of saying "number reported," would it not be well to put in the definite number?

Dr. Reichmans. I purposely worded it this way because I think it bears on future conferences.

The Acting Chairman. All right, sir; that seems to be agreeable. You have before you the nominations of the committee on nominations. What is your pleasure in the matter?

(The nominations were written on the blackboard at the front of the room by Mr. Holbrook.)

Mr. Brown. I move you that the recommendations of the committee on nominations be accepted as the wishes of this conference.

(The motion was seconded and agreed to.)

The Acting Chatrman. Nominations are in order for second vice president.

Mr. Miresell. I nominate for second vice president of the conference Mr. Thure Hanson, of Massachusetts.

Mr. Cluetr. I second the motion. 
Mr. Mikesell. I might make an explanation. I do this for this purpose: Mr. Johnson, our first vice president, resides in the State of California. $\mathrm{He}$ is not with us in this conference, although I, understand it was his intention to be here. Something might happen at the next conference that would prevent Mr. Johnson from being here, and Dr. Stratton might be called away again, and, Mr. Hanson being from the East. is almost sure to be here.

Mr. BARNARD. It gives the great State of Michigan pleasure to second the nomination of Mr. Hanson, from the great Commonwealth of Massachusetts.

Dr. Reichmann. I move the nominations be closed and that Mr. Hanson be elected by acclamation.

The Acting Chatrman. If that is agreeable to the wishes of the conference they will signify it by rising.

(The motion was agreed to by a rising vote.)

Mr. Hanson. Mr. Chairman and gentlemen, I wish to thank you for the honor conferred upon me.

The Acting Chatrman. I understand that the committee on resolutions is not yet ready to report. The paper on "Liquid-measuring Pumps" is a rather long one, and there probably will be considerable discussion upon it.

(A motion to adjourn was made and seconded.)

The Acting Chatrman. It has been moved and seconded that we adjourn.

(The motion was agreed to.)

(Accordingly, at $5.10 \mathrm{o}$ 'clock p. m., the conference adjourned to meet at 10 o'clock a. m., Saturday, May 24, 1919.) 


\section{SEVENTH SESSION (MORNING OF SATURDAY, MAY 24, 1919).}

The conference reassembled at 10 o'clock a. m., at the Bureau of Standards, Mr. L. A. Fischer, secretary, presiding as chairman.

The Acting Charrman. Gentlemen of the conference, inasmuch as you have a regular vice president present, I shall ask him to step forward and take the chair.

Mr. Hasson. I prefer that you retain it. The machinery is well oiled.

The Activg Chairatan. The machinery is at your disposal. Before we go on with the regular business we will have a telegram from Mr. Johnson, of California, read. It is as follows:

Sachamente, Calif, Muy 19, 1919.

Dr: S. W. STRaTron:

California pledges sincere aui cumplete cooperation, trustful that conference will be fruitful of constructive and uniform legislation. Our service, now well grounded in public confidence, demands efficiency, practicality, and Federal cooperation. Deeply regret my absence and sincerely wish you success.

(Signed) Charles G. Johnson.

(At this point Mr. Thure Hanson, second vice president, assumed the chair.)

LIQUID-MEASURING PUMPS. A SYMPOSIUM OF EXPERIENCES AND IDEAS FOR PROPERLY REGULATING THIS CLASS OF APPARATUS. DISCUSSION OPENED BY F. S. HOLBROOK, BUREAU OF STANDARDS.

Mr. Chairman and gentlemen, day before yesterday I was very sorry that I had not been able to prepare a paper on the subject of liquid-measuring pumps, and yet yesterday I was congratulating myself upon this very fact. This goes to show that you never can tell. I have no paper on this subject. My remarks will be extemporaneous.

I take it, it is not my function to go thoroughly into all phases of this subject, inasmuch as this number on the program is largely to be given up to the delegates. We want to assemble together at this time a large amount of data upon the condition of measuring pumps in the field, as found by you, to use as a basis of constructive action upon the subject. Up to this time, for various reasons, the subject of liquid-measuring pumps has never been given proper consideration by the conference, and our specifications are consequently woefully weak. I believe they number three. Any one who knows anything about the mechanism of liquid-measuring pumps will realize that three specifications can not cover that field.

The subject of liquid-measuring pumps has been separated into two parts upon the program, the first being called a "symposium of 
experiences and ideas." After the ideas and experiences and data of the delegates have been collected and heard, then we have to present a set of specifications and tolerance for the proper regulation of this type of apparatus.

However, if you will pardon me just for a moment, I would like to put into the record a few figures in regard to accuracy of pumps. They were gathered by the Bureau of Standards after the last conference was held in 1916, and they cover the field investigation of 183 pumps examined in several sections of the country, in the State of Illinois outside of the city of Chicago, and in several other districts. Of these 183 pumps 7 per cent were found to be delivering more than the amount represented and 93 per cent were found to be delivering short measure. Five were outside the tolerance in excess, 7 were inside the tolerance in excess, 19 were inside the tolerance in deficiency, and 152, or 83 per cent of all those examined, were tested and were outside the tolerance in deficiency. The total errors ranged from plus 3 per cent to minus 28 per cent.

Now, I would like to say just a few words as to the opinion of the Bureau regarding the best way of handling this subject this year. These specifications and tolerances were not distributed to the delegates and the manufacturers a month or six weeks before the conference, although the Bureau heartily agrees that in every case, where possible, this should be done. However I think we may say that we have no apologies whatever to make on that score. The war threw the subject of measuring pumps distinctly into the background. We did not have the time to give the subject proper consideration, and, as a result, when we present this set of specifications and tolerances to you we want you to realize that they are simply suggestive on the part of the Bureau. They were prepared largely by Mr. Schlink with some amendments on the part of other members of the Bureau. I repeat, then, they are merely suggestive, and we want a thorough and complete discussion of the entire subject. Take these specifications and read them over. (I will call upon Mr. Schlink to accept the responsibility of explaining many of them and of justifying many of them, if justification be necessary.) Amend them as you think proper and wise, and, if you please, adopt them; but it should be very definitely emphasized that we believe they should not be finally adopted. at the present session. The time is too short to expect to arrive at any perfect code. We would suggest that they be adopted, if you please; tentatively. We then go upon record to the effect that these specifications and tolerances as adopted here are the present ideas of the conference as to what should be done in regulating this class of apparatus. Take these tentative specifications of the conference back to your various jurisdictions and enforce them in so far as you find it possible to enforce them. In any event, in every case find out what the effect in your jurisdiction of rigid enforcement of these specifications would be. If you find them to be practicable and workable as a set of specifications, enforce them rigidly, because if in your judgment they are proper, it is proper that they should be enforced by you. If you find any of them so impracticable that in your opinion they can not be enforced, note this fact, giving your reasons therefor, and send the material to the committee on specifications and tolerances. This committee on its part will pledge itself, I have no doubt, 
to get in touch also with the manufacturers of pumps, listen to any criticisms or suggestions which they may desire to make, and, perhaps, from time to time you can make a brief of the progress and the suggestions made and furnish them to the delegates of this confrence for consideration. You can discuss matters with the tolerance committee by mail or otherwise from time to time and, with the mass of data which we will get through cooperation of all delegates, the tolerance committee will be enabled to draft a code-it may be the same as this or may be different from this-and send it out broadcast one month or six weeks before the next conference is due to convene. You can, in the light of your experience of this year, study this set of specifications and tolerances and come to the conference prepared to adopt a set of tolerances and specifications for these pumps which will be complete, proper, fair, and workable, which will do justice to both the manufacturer of pumps and the consumer of gasoline. This, if you please, will be the final opinion of the conference as to what form the specifications and tolerances should take.

Now, all this, of course, is merely suggestive. You may follow some very entirely different course, but the Bureau believes that that would be the fairest way to go about the matter. It will not put the conference in the position of saying this year, "Here is what we are going to do in the case of gasoline pumps throughout the country," and then coming in next year to say, "We thought that was what we were going to do, but what we are really going to do is this, which is different." You throw the industry into confusion every time important changes of that kind are made.

While this is not the proper time to talk about the specifications and tolerances, because, according to the scheme of things, they are not yet before you, nevertheless, I think it will be excusable if I mention one point here, and that is that the bureau recommends an increase in tolerance of some 33 per cent, and we think that the reason for this change is a sound one. As you know, the conference adopted some years ago tolerances upon measures of $1,2,3,4,5$, and 10 gallon sizes, and at that time they placed the tolerance in deficiency at a certain figure and the tolerance in excess at twice this figure. That was done for the reason that it was believed that if any error was made in filling an ordinary liquid measure it would probably be in deficiency; there would be many slight errors in deficiency, even when the attempt was made to use the measure properly, due to the failure to fill the measure or to the spilling of small quantities. It was believed that if the tolerance in excess was slightly greater than the tolerance in deficiency, we could very much more safely guarantee the delivery to the purchaser, and the delivery is in the final analysis the thing of interest to all weights and measures officials and to all purchasers. The tolerance on machines simply leads up to the approximately correct delivery, a commercially correct delivery, a delivery as accurate as can be expected in ordinary trade.

Now, were it possible to take these gasoline pumps apart and test separately the measuring chambers, then perhaps we would have a condition analogous to the testing of the ordinary measure. We would then have a delivery error on the commodity consisting of the tolerance error upon the measure itself and the error of use of the measure. 
But gasoline pumps so differ from measures in this respect that one never tests the measuring chambers of the pump itself. The thing that is tested is the delivery of the pump, the amount of gasoline actually received by the purchaser. Therefore, in the case of a gasoline pump, the two sources of the final error of the ordinary delivery by liquid measure are both present in the result of the test made. Therefore, there seems to be no particular reason why the tolerance in excess upon the gasoline pump should be greater than the tolerance in deficiency, since no additional error, usually in deficiency, is to be guarded against. If the tolerances are the same in excess and deficiency and the pumps are not adjusted to take advantage of that tolerance, and if there is no fraudulent manipulation, then in the long run the purchaser should receive an amount that averages correct; that he will receive individual amounts in which the error can be neglected because the tolerance fixed, we believe, is small enough so that the pumps can not be adjusted so as to take advantage of the tolerance.

Mr. Schmitz yesterday said that he would be a very good scale mechanic who could take advantage of a tolerance of one-half pound per thousand pounds upon a grain scale. From what we know about pumps we may say that it would be a well-nigh perfect instrument and an extremely good mechanic that would be able to take advantage of the tolerance fixed for gasoline pumps. Any attempt to take advantage of these tolerances is almost sure to be followed by condemnation of the apparatus, since it is very difficult to control the errors within the small range which will be in effect even when the present tolerance in deficiency is doubled. However, we throw an additional safeguard around the tolerance by requiring that when a gasoline pump has been repaired and is being retested, then, if you please, on this test the error allowed shall be one-half the ordinary error allowed, or, in other words, repaired pumps shall take the same tolerance as new pumps. Take an example. A pump is allowed to remain in use until it is more than 1.8 cubic inches short per gallon. The pump is tested, found to be 21 cubic inches short per gallon, and is condemned. It will not in that case be satisfactory to bring the pump back to 1.7 cubic inches short per gallon. Under such circumstances the pump should not be sealed. While the repair and adjustment is being made the repair man must bring the pump back very much closer to accuracy, and sealing should not take place until a test shows it to be within 0.9 cubic inch per gallon. The pump will then have a slight leeway over which it will be allowed to pass before it need be again condemned by the inspector.

One other point. You have copies of these specifications and tolerances in your hands. In making the mimeograph for these specifications an important specification was omitted. We have had extra copies of this struck off, and these will now be passed out to you. We consider this specification an important one and ask your attention to it at the proper time.

The program states that I will open the discussion. I am now through with my explanations, and I take it, therefore, that the discussion may be considered as officially open to the delegates. 


\section{DISCUSSION CONTINUED BY MEMBERS.}

The Acting Chatrman. The discussion on liquid-measuring devices or pumps is now open.

Mr. Stewart. I want to raise one question with Mr. Holbrook. Should an inspector, either county or State, seal a gasoline pump? If so, why? If not, why?

Mr. HoLbrook. Does the inspector of weights and measures seal scales? Do you seal scales in your State, Mr. Stewart?

Mr. Stewart. Yes, sir.

Mr. НоцвRоок. In what essential respect does a pump for the distribution of gasoline by measure differ from a scale for the distribution of food by weight?

Mr. STEWART. Quite a difference.

Mr. HoLвrook. Explain the difference and I can answer your question.

Mr. Stewart. In the first place, if we test a scale and we seal that scale, in case of some error occurring in it there is nothing to prevent the owner from having it adjusted; but a gasoline pump is so constructed that when you seal that pump as it should be sealed, then the individual can not move the adjusting parts. If he does and you go and find the seal broken and the pump used, it is prima facie evidence against him that he has been tampering with the pump. If you leave the pumps unsealed and hold him responsible for the condition in which you find them, it is up to him then to have 1 and 5 gallon measures and from time to time test them. If a scale is out of balance the merchant can correct it.

Mr. HoLвRook. Yes; but there are very many things which happen to scales which tend to make them incorrect, but which do not affect the balance of the scale in any way.

Mr. Stetrart. That is a fact.

Mr. HoLbrook. I would say that you seal measures. Gasoline pumps should not need to be balanced any more than a measure needs to be balanced; it should not be necessary to adjust the stops from day to day. If you seal liquid measures, why not seal gasoline pumps? Perhaps you have not sealed gasoline pumps in the past. The reason you have not sealed them in the past is perhaps that you have found they do not remain accurate. If that is at the bottom of it, and, in fact, gasoline pumps do not remain accurate, then they are not proper measuring devices. If a set of proper specifications be adopted, galoine pumps complying with these specifications will remain accurate; therefore, your objection to sealing the device will no longer be a valid one and there can be no objection left.

Mr. Stewart. Mr. Holbrook, excuse me for replying to the question you asked, and that is about the balancing of the gasoline pump. If I go and test a scale, and for some cause that scale gets out of balance, I do not see why the merchant can not put it in balance again. But if I seal a gasoline pump he can not put it in balance without breaking my seal.

Mr. HoLBRook. How does a gasoline pump get out of balance?

Mr. Stewart. Various things cause it to get out of balance. What I mean by balance is to have it give what it is supposed to give. That is done from different causes. Some little thing may get in 
under the foot valve, which will let a little liquid drain back. Another way that it gets out of balance is that the proof of the gasoline varies. A low-proof gasoline will give one amount; a highproof gasoline will give another. You have to adjust it to the sort of gasoline that you are using; and there are other reasons why you need to adjust it, and if you seal this you prevent these adjustments.

Mr. Holbrook. Would you adjust the measuring chamber of a liquid-measuring pump in order to compensate for a leak in the foot valve?

Mr. Stewart. Mr. Holbrook, you have valves in all sorts of pumps. You get a little grain of sand or hard substance in and leaks result.

Mr. HoLBRoox. I agree that valves occasionally leak.

Mr. Stewart. It may cause just a very small leak, and yet if that is adjusted it will be practically correct.

Mr. Ноцвоок. Suppose a gasoline pump is used three times in 15 minutes with a leak of five minutes between each delivery, and then is left to stand for an hour or two, or overnight. Do you think you can adjust the measuring chamber of the pump to take care of the leak which occurs in five minutes, and also secure the adjustment of a leak which occurs during three or four or half a dozen hours? I think the proposition is not tenable. It is getting ahead of the subject. One of our specifications, No. 5, prohibits adjustments made to compensate for leaky valves.

Mr. Riondan. Mr. Holbrook, would you advise the sealer to place the seal on the individual stop?

Mr. HоLввоок. Yes; provided that you have a measuring pumpand this is what we are attempting to get-which remains permanently in adjustment as every other piece of apparatus, satisfactory to be commercially used, should.

Mr. Hanson. Mr. Riordan, relative to the sealing of these individual stops, assume that the pump gets out of order and the garage man, or filling-station man, wants to regulate it. Do you think it would be allowable for him simply to say, "This stop has been sealed by the sealer; I can not touch it, or I am prima facie liable in court." Ought he not to be allowed to break the seal to readjust the pump?

Mr. HoLBRook. He should send for the sealer of weights and measures.

Mr. HANson. Is that practicable?

Mr. Holbrook. It is practicable just as soon as we get pumps which remain within tolerance.

Mr. Hanson. I am assuming present conditions.

Mr. Ноцввоок. I am not talking about present conditions, but about conditions when this set of specifications and tolerances goes into effect. Moreover, I may say this discussion is not proceeding in exactly the way we assumed it would proceed. If you want to say anything about measuring pumps in your jurisdiction under present conditions say it now. Then let us take up these specifications. Every point which has been raised so far is covered by the specifications. Let us read our specifications and discuss them one by one instead of jumping around from one to another.

Sealers all over the country have been telling us that they had a lot of data on liquid-measuring pumps in their various juris- 
dictions. Now, if anybody here has anything to say about the condition of gasoline pumps in his jurisdiction, or wants to explain any special difficulties which he has had in relation to this apparatus, groundwork that will explain why we are now attempting properly to regulate measuring pumps, why not tell it now? Has anybody here any data which he wants to present to the convention as to the difficulties he has had? Has anybody here allything to say? If there is nothing to be said on the matter it will be the first conference on weights and measures where officials have had nothing to say on the subject of regulating measuring pumps. Mr. C. C. Townsend. Do you want to know some of the experiences we have had?

Mr. HoLBrook. I think this conference wants to know, because members have told me so separately.

Mr. C. C. Townsend. I had one little experience, and I would like to know how you are going to overcome such a condition. There was a pump in our neighborhood which I had trouble with, and the pump man got it adjusted so that it was correct, and I tested it every once in a while. I tested it five times one day and every delivery was correct. While we were still standing there a man came up and said, "I would like to have a gallon of gas," and presented a can. The man that had worked the pump for me put the end of the hose in the can, turned the handle, picked the can up, and handed it to the man. That delivery happened to be a quart for a gallon. I went to that same pump and got 5 gallons of gas for myself. I was sitting in my wagon holding the hose in my hand. When the second gallon was pumped I thought I noticed a dropping off in the amount of gas coming into the can. The fourth gallon was over $1 \frac{1}{2}$ quarts short. Suppose I had sealed that pump. It would have been several days before I would have been able to get back to knock that seal off for him. I do not think it is practicable to seal those adjustments.

The Acting Champran. I think it would be better to take up the tentative specifications as outlined here.

Mr. BARnard. It seems to me, in accordance with the thought of Mr. Holbrook, that there are quite a number of things that are to be thoroughly discussed before this conference starts on these specifications. Anything I may say will not be in a spirit of animosity, but I desire to be extremely frank in what I may say, and I hope that the representatives of the various pump companies will take it so. In the first place, in my judgment, we have been going about the inspection of gasoline pumps by putting the cart before the horse. You go up to the pump with your measure, proceed to extract a gallon from the pump, and find an error. You have no way of knowing at that time what is causing that error.

I have found in my experience that the largest cause of errors in gasoline pumps is faulty installation. It is natural to assume that a gasoline pump is manufactured by the various gasoline-pump-manufacturing companies as near perfect as possible from a mechanical and structural standpoint. These pumps are tested in factories and found to throw an accurate amount of fluid before the pump is allowed to go on the market. Very well so far. That pump is shipped to its ultimate delivery point and there delivered in its crate to the 
purchaser. There the responsibility of the gasoline-pump company ceases, and any Tom, Dick, or Harry proceeds to set up that pump. The gasoline is delivered from the underground tank through a series of pipes which must necessarily be properly installed in order to obtain the correct delivery. The ordinary man that installs a gasoline pump pays no particular attention as to whether he has done it properly or whether he has half a dozen different angles in the piping. Now, just the minute an incorrect angle is established in your pipe you are going to establish an air pocket, the same as an air pocket in a steam pipe, and that minute you have established an error in that pump and you can adjust the pump until doomsday, but you will not get a correct measure.

That is only one reason. A good many pumps have joints in a great many of the pipes; they are put in with different packing materials. I heard the other day of a man using soap to connect a pump. To my knowledge there is only one material that should be used, and that is litharge, and that must be properly put on; otherwise you have a leak in the pipes.

The next proposition to my mind is the condition of the foot valve. In putting the gasoline into the pipes, unless great care is used, sand is going to get in, and the minute you get sand into the pipes you will have more or less trouble with the foot valve. It seems to me the principal thing we must consider before we take up anything else is some sort of regulations relative to the installation of gasoline pumps.

When I first faced the installation of gasoline pumps in the city of Battle Creek, I found all sorts of trouble. Some 78 per cent were in error. After giving the matter consideration, I found that the trouble was in the installation. I required every pump I found in error to be taken up and the installation examined and replaced properly. Since that time I have required that each and every installation shall be examined before the pipes are covered up.

We have had considerable trouble in Michigan. Almost 60 per cent-59 and a fraction-of the pumps tested in the State of Michigan were found in error. It seems to me imperative at this time that we should take into consideration the installation of the pumps.

Now, for some reason or other it seems to be the attitude of the pump-manufacturing companies to disregard installation. I do not know why that is so. A scale company sending out a large scale sends you a blue print for the foundation of your scale, and they are insistent that that foundation be correct before they put up the scale thereon. There should be just as much consideration taken by the gasoline-pump maker, in my opinion, as there is by the scale maker, especially in view of the present high price of gasoline.

We tried in Michigan a month or six weeks ago to put through the legislature certain legislation which would regulate to a certain extent the gasoline-pump proposition. Immediately we had the animosity of certain pump-manufacturing companies who came to Lansing and did everything in their power to destroy that piece of legislation. That does not appear to me to be cooperation in any sense of the word. They wrote a letter to every garage man in Michigan arguing that legislation should be defeated and they asked every garage man to go to his senator and representative and ex- 
plain to them that they had already invested considerable money in gasoline pumps and should not be disturbed. I have reached a point where I have lost confidence in that sort of procedure. It seems to me that the strictest kind of regulation should be established for these gasoline pumps.

The Acting Chatrman. I may say for the information of the speaker that in our State, Massachusetts, the installation of pumps of whatever make they may be is always handled by the experts of the respective companies. Further than that, I think we never have found any case of a pump which was incorrect and which could not be adjusted by the sealer, or where a telephone call to any of the companies would not have an immediate response. They have in the different localities corps of workmen. We have no trouble whatsoever as to installation; it is all done by expert workmen.

Mr. Ноцввоок. Can we find out at this time how many delegates will be present at lunch, so that we can make proper arrangement for their entertainment?

Mr. STEWART. Will there be a session this afternon?

Mr. HoLbrook. This session will run through into the afternoon if you want it to. We still have to dispose of these gasoline-pump reports and the specifications and tolerances, which I do not think should be hurried, reports by the resolutions committee and other standing committees, and the inspection of the laboratories.

Mr. STewart. In order to settle the question, I want to get at it this way: I move, if I can obtain a seconder, that we continue in session if it takes until 9 o'clock to-night.

(The motion was seconded and agreed to.)

The Acting Chairman. That means the majority here will have lunch at the Bureau.

Do you want to go on discussing the experiences you have had relative to your individual cases? If that is the case, why not fix a time limit? If we do not, I am afraid we will go on talking here from now until 9 o'clock to-night, and get to no definite results. Personally, I believe we could fix $11.15 \mathrm{a}$. $\mathrm{m}$. as a limit for discussion, no man to speak more than five minutes, and then go on to the tentative specifications.

Mr. Seraphim. I have a short paper which it will not take more than two minutes to read.

I desire to make a few remarks regarding my experience in the inspection of automatic liquid-measuring devices, but my object in attending this conference is more for the purpose of learning, for I believe that anything I might say would be only what is already known, especially in view of the fact that there are so many here who have such a very wide range of both practical and technical experience.

There is no doubt but that the subject of automatic liquid-measuring devices is one of the most important that confronts all weights and measures officials throughout the United States, due almost entirely to the phenomenal increase in the amount of gasoline vended to-day through these devices.

In a sense, so far as our supervision is concerned, this subject is in its infancy, owing to the fact that the use of these devices has increased so rapidly in the last few years and at the same time that 
the study of the situation was to some extent retarded by the late world conflict, which made other work more important.

There are a number of phases to this situation which are of great interest to-day, and I will confine myself to one which has given me the most trouble and which, if corrected, will be getting at the root of most of our difficulty, and that is the absence of supervision by weights and measures officials of the method of installation.

I desire to state that every weights and measures official should be provided with some standard set of rules and regulations governing the installation of any automatic liquid-measuring outfit, and its enforcement should be effected by them while the installation is being made, for, unlike scales, weights, and measures, which are always entirely exposed to the eye of the inspector when making a test, these devices have most of their arlangement under the ground and are sealed over with a heavy cement paving.

There is no doubt that many pumps which are in all probability correct are condemned for the following reasons:

First. By faulty and careless installation, where such installation is made by some one who is incompetent or is not thoroughly acquainted with the important rules set down by the manufacturers of these devices.

Second. Where rules set down by manufacturers are deviated from for the purpose of overcoming conditions in a building or premise which are not favorable for the proper installation of a pump.

This condition of faulty installation, in my opinion, exists to a much greater extent in Philadelphia than anywhere else, for, besides the absence of any supervision of the method of installation, we are handicapped also by an antiquated ordinance which prohibits a pump being installed at the curb, which for a sidewalk pump is the best location, since it secures the maximum efficiency, especially when lised in conjunction with a hose discharge properly arranged and equipped with an overhead automatic air valve, so that hose may be easily and thoroughly drained from a definite level." An arrangement of this kind, when properly installed, gives very good results and is the most popular in use to-day.

In Philadelphia, where sidewalk pumps have to be installed at the house line, a pipe is generally run under the sidewalk to the curb, where a connection is made at the surface of the pavement to a hose, or a pipe is extended vertically at the curb to a certain height and a hose connection made with it. In some cases a vertical pipe is also extended vertically above the pump, then down again, and under the sidewalk to the curb. In some cases an overhead automatic air valve is provided, and in others there is not. Some hose nozzles are provided with a shut-off valve, and others are not, thereby proving that there is no recognized method-at least in Philadelphia-which is considered the best. None of the above methods improve the efficiency of the pump, but, on the other hand, the reverse is the fact.

If one of the results of this conference is the formulating of specifications which will be enforced by the inspector or sealer, when the installation is being made, then a great stride will have been made which will not only help to protect both the purchaser and seller of gasoline, but will be of benefit to the mannfacturers of these devices and greatly lighten the work of the sealer. Such specifications could 
then be used as a basis for having any ruling or ordinance changed in any locality which tends to prevent the proper installation of any automatic liquid-measuring device.

Mr. Stewart. Answering Mr. Holbrook's question, I want to use just two of our own cities. In the city of Wheeling--I have forgotten the exact number of pumps we tested-64 per cent of the pumps were out of tolerance, 51 per cent of the total number, or about 80 per cent of those incorrect, being against the consumer. If I remember rightly, they were in error on an average of something like 14 per cent. We found one pump that was supposed to throw a gallon at a stroke. It took 14 strokes to give 10 gallons. Then, in Parkersburg we found that 73 per cent of the pumps were out of tolerance against the consumer, and these were in elror by about 9 per cent, on an average. That will give you some idea of what we found in these two towns.

Mr. Schoenthal. In the District of Columbia we use a large sign, about 9 by 11 inches in size, printed in red, a very distinctive sign, which we attach to condemned pumps. It is needless to say that, when one of these is put on, the owner is in great haste to have his apparatus repaired in order to get rid of this red sign. One of the pump agents asked me one day as I was placing a card on one of his pumps, "Why do you condemn that pump; there is absolutely nothing the matter with the pump. The trouble is with the installation." Of course, he knew and I knew why we condemned the pump, but there is a thought there, and that is that we condemn the pump very often when the pump is accurate, but the installation faulty. In 1918 we condemned 37 per cent of the pumps tested, and I feel safe in saying that 90 per cent of the condemnations were due to the fact that the installation was faulty and the pump correct. From February 3 to April 2 of the present year we inspected 13 newly installed pumps, and 13 , or 100 per cent, were condemned on account of faulty installation. It seems to be a common thought among buyers of pumps that any plumber can install a pump. A greater fallacy never existed, because the average plumber regards a little leak as being of no consequence, thinking that it will draw up the same as a hot-water pipe. Instead, gasoline very often will cause an increase in the leak.

One of the criticisms which I would make is that a great many of the pumps, or at least some, are so constructed that the discharge point is below the level of the automobile tank or other container to be filled. This, of course, was excusable at one time, but in this present day of enlightenment it seems ridiculous that the companies still manufacture pumps of that character.

I am informed by a representative of one of the pump companies, who is here to-day, that his company, and I think it is true of all other companies, furnish to each purchaser of a pump a pamphlet of instructions showing definitely how the pump is to be installed. I do not think that the great percentage of errors is due to the pump. There are some few cases where there are bad plunger washers and, possibly, leaks in the packing boxes, but I think the majority of errors are due to faulty installation.

Mr. Maixen. Just a word. Mr. Seraphim referred to the connection of the pump with the tank. Of course, the tank may be located some distance from the pump. Some one mentioned plumbing. In 
most cities it is necessary to get a plumbing permit. Why not make it necessary to secure a permit to install a pump?

Mr. Barasard. In the city of Battle Creek they have to do that, and they have to secure a licensed plumber to do that work. Even after doing this it is required that inspection be made by the chief of the fire department as to hazardous conditions and by the sealer of weights and measures as to accuracy, etc.

Mr. Schoenthal. In the District of Columbia the permission of the fire department must be secured, and we allow none but registered plumbers to do any plumbing work, which necessarily shows that these pumps are installed by plumbers. However, plumbers are not experts in installing gasoline pumps, and that is where the trouble comes in.

Mr. RUNBeck. In regard to sealing the gasoline pumps, when I first started work in South Dakota on gasoline pumps I sealed them, but in the last six months I have not done so, because I consider that the State seal placed on a gasoline pump is a guaranty to the public that it is correct. I now simply attach a tin tag showing it has been inspected on such and such a date. I am opposed to sealing gasoline pumps, because they apparently will not stay right. In starting the work I found that out of over 2,000 gasoline pumps 78 per cent gave short measure. That was on the first inspection, and I am not quite through with it yet.

Mr. IRvive. Would it not be a good plan to require each person tbout to install a gasoline pump to notify the inspector of this fact? Then he would get the proper instructions. I think that would obviate the trouble. I know one man who had a plumber install a pump and cement the tank, and who then sent for me to inspect it. He had a leaky installation and had to go to the expense of tearing up the sidewalk again. I think it would be a good thing to adopt the plan proposed.

The Actisg Chamman. I presume that would involve securing necessary legislation relative to installations, etc.

Mr. Schlivk. With respect to the matter of installation of pumps, I think much of the trouble is due to the fact that the plumbers are not literary men and will not stop to read the voluminous instructions sent out by the pump manufacturers regarding installation. Many of the defects are clearly set forth in the instructions sent out by at least two or three of the makers, but these take more careful thought and reading than the average installer is going to give them. He thinks they are theoretical requirements made by the manufacturer. If, however, sealers of weights and measures would prepare a summary of these requirements based upon the best information obtainable, distribute this in printed form to every garage owner who may install a pump, and make it clear that these requirements are mandatory, not suggestive, and are based upon sound engineering knowledge of the difficulties that are going to arise, then care in installation could be maintained. It is a matter of putting necessary force behind it, taking it out of the hands of the manufacturer who may or may not be followed by the plumber, and putting it officially to make it clear that he must follow it or, if he does not, that his installation will be condemned without the carrying on of a test. Mr. STrwarT. In regard to the plumber, I want to say, with all due 
lespect to him, that the plumber is not fit to install pumps. Why? Because he is not an expert pump man and does not figure on the pump being built so that it must produce a vacuum to carry up the liquid that is beneath. In order to install a pump, you must know something about a pump. I know a plumber that installed a lift pump in a house 60 feet above the water level, and you know the amount of water he got up there. You must have a man who has studied these things. I believe the way to overcome faulty installation is to have the regulations require that the seller of the pump install it.

Mr. Goodwin. I have had a little over 50 years' practical experience on this subject and have installed a great many of all kinds of pumps. I believe that the whole trouble lies in faulty installation. 'The suction pipe may', for instance, be so laid that there will be an air trap in it. This has occurred in my experience.

I have had a great deal of experience with pumps on driven wells. We had trouble when particles of sand got under the valve. While the valve is working it may be hardly perceptible, but the moment you stop that valve you will lose your liquid. To correct such a condition, we have what is called a sand chamber, which catches particles of sand by slowing down the current of water, thus causing it to come through a small pipe into the cylinder. I believe if there was some device attached to the pump to catch particles of dirt and eliminate them from the check valve, we would overcome a lot of this trouble. I think the pump manufacturers could afford to furnish that, and I hope they will take this under consideration.

Mr. Irvine. I would like to ask a question. Is the subject of the quality of gasoline going to be discussed here at all? I am more interested in the quality of gasoline for distribution than I am in the installation of pumps, because I believe every one of you is sufficiently familiar with the installation of pumps to enable you to handle that yourselves.

The Acting Chatrman. That would be considered under new business.

The Secretary. There are a number of manufacturers of pumps here, and it seems to me they ought to be given an opportunity to ask questions.

The Acting Chamran. Do any of the pump manufacturers wish 10 be heard?

Mr. Corex (representing S. F. Bowser \& Co. (Inc.)). The only thing I would suggest in this connection has reference to the directions which are sent out with pumps. I believe in practice that two sets of complete direction sheets are sent out with every pump shipped. It is only necessary for any intelligent man to follow these instructions, and he will then have no trouble with installation. In addition to that, some years ago we went to considerable trouble and expense in issuing service bulletins, and $I$ will also call attention to the publication, Terhnological Paper No. 81, of the Bureau of Standards. On page 19 of this you will find illustrations for correct and incorrect practices in installing pumps. Bowser \& Co. is willing to furnish the sealers throughout the country with all of our publications they may require and can make use of. We want everything to be right. We manufarture, as do all the manufacturers, with the 
best judgment we have. If anything is not right, we stand ready to make it right and we will give all the information and assistance we can in having the equipnent properly installed and regulated.

Perhaps I might adrl a word further as to what has been suggested in the way of making manufacturers responsible for all installations. That, of course, is an utterly inmpossible task. Hundreds of thousands of these pumps are located at remote points all over the country, where we have no way of having representatives to make installations. We have to depend upon the men who make purchases to make installations, but we are ready to lend all the assistance we can to anybody who has any trouble.

The Acting Chalrinax. Mr. Corey, what do you consider the maximum length of pipe feasible from the tank to the pump?

Mr. Coney. I do not know that it has been reached. I make that reply for the reason that I know of installations that run up to 600 feet of horizontal line. I do not recommend that. But the point brought up by the gentleman gets back to the question of the kind of gasoline being handled. There are certain localities where the casing head or blended gasoline is used, and the handling of this differs from that of straight run. However, distances of 50, 60, and 100 feet are not at all uncommon. There are any number of such installations.

The Acting Chalriran. There undoubtedly is a difference be$t$ tween deliveries of 50 feet and of 600 feet?

Mr. Corey. Not necessarily. It depends upon the size of the pipe line.

The Acting Chamrian. Assuming that the size of the pipe and the installations are correct, would it make any difference whether the tank was 600 feet a ray from the pump or 20 ?

Mr. Conex. Not if you hare adequate piping.

Mr. Y AKE (representing Gilbert \& Barker Mfg. Co.). Mr. Chairman, the problem of instructing the purchasers of the equipment in regard to proper installation is one that we, together with the other companies, have been trying to solve, and we are looking for the best methods of getting at it. Each one of our equipments is accompanied with very explicit instructions, and the great problem is to get these instructions into the hands of the plumber or the inan installing them and get him to read and follow them. We have had many discouraging experiences in that connection and also encouraging experiences, and I might relate a lot of funny incidents. I will say this, that we want to join hands with the sealers and any other authorities that will enable us to guarantee absolutely correct installation, because our experience has shown that more than 90 per cent of the troubles are due absolutely to faulty installation. That has been our experience covering a period of years. We are always open to suggestions as to how to obtain the results that the sealers want or that the Bureau of Standards wants, and we are ready to cooperate for the best possible results.

Mr. TrNkex. I just want to relate to you in a brief way an experience I have had that seems to be different from the rest of you and that resolves this whole thing into carelessness. I passed a pump one day and sealed it. The next day a man complained, 'I got some gasoline at that pump and am short." I went down and tried it and 
got only $4 \frac{3}{4}$ gallons on 5 strokes; so I condemned the pump. The repair man came orer and he took out chewing gum and wrapping paper from nunder the last ralrc. 'That is carclessness of the man who installed the pump.

Mr. Bean (representing the Wayne Oil Tank \& Pump Co.). I simply want to say that the sealers have struck the keynote of the major portion of the trouble in measuring pumps in the question of installation. A few days ago I was in the city of Buffalo, and while taking a drive, saw an excavation being made in which to install a pump. I stopped and looked into the hole. I asked the man what he was using on the joints. He said, "Soap." I said, "Did you ever install one of these pumps before?" He said, "Yes, I installed three last week." I said, "What did you use on those?" He said, "Soap." I presume that in the collse of a very short time those pumps are all going to give trouble. 'The sealer had absolutely no opportunity to examine those pipes before they were covered. He does not know how they are put together. He is going to assume there is something wrong with the pumps and condemn them. I believe that all installations should be examined by the sealer before they are covered. I believe that that should be covered by proper legislation. I want to say that the company which I represent is more than anxious to cooperate with the sealer's and authorities in charge of this class of work and to do anything in its power to correct the troubles that are now existing. I thank you.

The SECretary. I might relate a little experience the Ordnance Department had during the war that has a very direct bearing on this subject. In the manufacture of gas shells it was decided to use the Briggs pipe thread-that is, a thread which is more or less tapered-and notwithstanding the fact that every one of these threads were gaged with special gages and inspected to determine whether they were of the correct size, there were hundreds of thousands of these shells rendered useless on account of leaks after being put together. Of course, gas was put into these shells, and it was a severe test; but the fact remains that large numbers of them leaked, notwithstanding that they took extraordinary pains to have the joints made tight and that they were all put together in shops where they had facilities for doing it, and under supervision. One of the areatest difficulties encountered was to get a gas-tight shell.

Mr. Goodwr. Was there a hydrostatic test?

The SECreTaRY. They were tested with the gas itself; they put the gas in the shells and leaks were found.

Mr. Schlink. Mr. Stewart has asked me to emphasize the fact that plumbers in installing these pumps are inclined to follow their own judgment rather than the instructions of the pump manufacturers. He wished me to emphasize that in some way it should be possible to invoke the police power so that these instructions nust be followed: so that they will be mandatory and not permissive. These specifications have been prepared with the idea that forms of installation and of pump construction should be discussed to determine final results. I think it will be a mistake to assume that installation will explain everything and that if you have correct installation it makes no difference what type of pump you have or what specifications you have adopted as a safeguard. 
Mr. Riondan. The State Sealers' Association of Massachusetts is the only association in the entire Union to appoint a special representative to attend this conference; so I would like to call upon the special representative from Massachusetts.

Mr. DAX. I do not see where the delegates from the cities have much to do with this convention. The State men do the whole job. I think there should be a national association of local sealers where we could get together and talk and not bring it into this conference.

The Acting Champian. The time is now up for discussion, and I suggest that we proceed with the specifications.

TENTATIVE SPECIFICATIONS AND TOLERANCES FOR LIQUIDMEASURING PUIVIPS PROPOSED BY THE BUREAU OF STAND. ARDS, AND THE DISCUSSION THEREON."

Mr. HoLвRook. I will ask Mr. Schlink to read the specifications.

Mr. Schlink (reading) :

1. Definition.-A liquid-measuring pump is a pump, or a combination of a pump, with other mechanism, adapted to the measurement of liquid in definite quantities by volume.

Mr. Stimpson. I would like to ask if this definition is intended to include all of the installation and everything that goes with the outfit?

Mr. Schlink. It is meant to include the whole combination. Perhaps the wording ought to be clarified.

('There being no further discussion, a motion to adopt the specification as read was duly made and seconded, and the motion was agreed to.)

Mr. Schunk [reading]:

2. Permanence.-(a) Liquid-measuring pumps shall be of such design, construction, and materials that they may reasonably be expected to withstand ordinary usage without impairment of the accuracy of their measurement or the correct functioning of their operating or indicating parts.

(b) The longitudinal axis of the measuring cylinder or chamber shall be accurately plumb when the pump is in level, and a two-way or a circular level or leveling lugs shall be provided by means of which the level can be established. The installation shall be of such strength and rigidity as to maintain this plumb and level condition during the life of the apparatus.

Mr. Barnard. I would like to ask Mr. Schlink if in that there is anything to cover installation?

Mr. Schlink. There are half a dozen paragraphs that cover installation. This relates only to the things regarding installation that may be expected to change with time and that should be safeguarded in order that the installation may remain as it was put in.

Mr. Barnard. To my mind the language in those two paragraphs covers the proposition in a general way, but it would leave it a inatiei of construction, and it seems to me in this matter that we should be more or less definite.

Mr. Schoenthal. Paragraph (b) as read may be of some benefit, but I can not see it-the words at the end of the last line, "to maintain this plumb and level condition during the life of the appa-

${ }^{1}$ For the complete set of specifications and tolerances, as adopted, see Appendix, p. 223. 
ratus." It strikes me that to maintain this "in level condition" would be sufficient.

The Actixg Chairmax. Do you see any objection? What do you say to that, Mr. Schlink?

Mr. Schlixk. I think that change might well be included. I do not see any objection to it.

The Acting Chairmax. Is there any other question as to subdivision $(\alpha)$ ?

(There being no further discussion, a motion to adopt paragraph (a) of specification No. 2, as read, was duly made and seconded, and the motion was agreed to.)

The Actisg Chairmax. It is moved that this be adopted with the words "during the life of the apparatus" stricken out, so that the last sentence of section (b) of specification No. 2 shall read:

The installation shall be of such strength and rigidity as to maintain this plum and level condition.

(The motion to adopt paragraph $(b)$ of specification No. 2 as amended was agreed to.)

Mr. Corey. May I ask what is intended by the words in paragrapl (b) " a two-way or a circular level, or levelling lugs."

Mr. Schlixk. It provides merely that facilities shall be provided by which the installer may determine when he has the pump plumb and level.

Mr. SCHLINK (reading) :

3. Indicating and registering parts.-( $\alpha$ ) Counters, meters, and graduated scales used on liquid-measuring pumps to tally sales and deliveries to individual purchasers shall be so located and disposed that their readings will be visible to the customer as well as to the operator of the pump.

(b) Iu the case of measuring pumps used for dispensing gasoline, the counters shall be of such size and style that thes are clearly visible to, and realable by, the customer from any position which he may reasonably be expected to assume.

In that connection there will be excluded from the action of this specification certain counting devices which are provided by the manufacturer for the conrenience of the dealer for totalizing his sales so he can compute the sales and losses.

The Acting Chairiras. Is there anything to be sajd on paragraph (a) of specification No. 3 ?

Mr. Corey. May I ask all the questions I want to about this? That means the customer as well as the one operating the pump. One of the questions is, "Where?"

Mr. Schuink. In any position he can reasonably be expected to assume in buying gasoline.

Mr. Corey. Does it mean when he is sitting in the car?

Mr. Schlink. Standing or sitting in the car, or outside, holding the hose.

The Acting Chairmax. With particular reference to the 5-gallonstroke pump, with the scale on the side. I do not see how a man could very well see that unless he got out of his car and stayed outside.

Mr. Schurnk. Perhaps the phrase "from any position which he may reasonably be expected to assume" ought to be included in the first paragraph also. 
Mi: Stewart. It seems to me as if we have got a specification for a specific pump. I do not like the tenor of that part. We want to think about that as we go through these specifications. There is what we call the visible and the invisible device. Now, are we going to get up a specification that is going to make them all become visible? If so, let us say so plainly.

Mr. HoLbrook. This does not refer to a particular type. Every gasoline pump of which I have knowledge has some form of counter to show how much is being delivered to the consumer. You would not have an absolutely blind pump?

Mr. Stewart. Oh, no!

Mr. Holbrook. If a counter is incorpolated, that counter is for the purpose of informing the consumer how much he is getting, and this simply requires that counter to be in a prominent place and of sufficient size to fulfill its function.

Mr. Stewart. Whether the purchaser is in the car or at the hose?

$\mathrm{Mr}$. HoLвrooK. The specification as originally written provided specifically that the man might be in the car. I do not think that the purchaser is in "a reasonable position" when he is in his car, and the specification now merely contemplates any position he may l'casonably be expected to assume. I never sit in my car when they deliver ine gasoline. I think in adopting this that this conference should have in mind that a person sitting in a car is not in a position he may reasonably be expected to assume to check his delivery. The delegates can interpret that specification.

If we may go back to specification No. 2, paragraph (b), it seems that the words "or a plumb bob" slould be included after the words "leveling lugs." A plumb bob is a satisfactory means of determining a level in this case.

I will make a motion to that effect.

Mr. SCHLink. I second the motion.

The Acting Chatrman. It is moved and seconded that in specification No. 2, paragraph (b), after the words "leveling lugs," the words "or a plumb bob" shall be added.

Is there any objection to that?

(The motion was agreed to.)

Mr. Stimpson. I would like to move you that the words "from any position which he may reasonably be expected to assume," just now read in paragraph $(\dot{b})$, be inserted at the end of paragraph $(a)$ in specification No. 3.

The Acting Chairuan. The motion is made that the words "from any position which he may reasonably be expected to assume" be added at the end of paragraph $(a)$.

Mr. Holbroor. I understand that these words should not be put in there for the reason that many pumps have counters which are for the information of the consumer and have also a meter which tallies total sales. The latter need not be conspicuous to the purchaser.

Mr. Schlink. That is covered, Mr. Holbrook.

Mr. HoLbrook. A pump often has both a counter and a meter. This provides that the counter only should be visible from any position; the meter is almost solely for the information of the operator of the pump.

Mr. Schunk. They say you can not sce any counter if you are sitting in the car with a rear-end tank. 
Mr. HozвRook. Is that not covered by paragraph (b)? When there is a counter on a pump, it must be conspicuous; if the purchaser desires to read the meter in addition, he should put himself in a special position to read it. The fact that counters, meters, and graduated scales are mentioned in paragraph $(a)$ makes it inadvisable to add the suggested words there. Graduated scales, however, might well be included in paragraph $(b)$ also, although meters should be left out.

I will amend the motion to the effect that the words "and graduated scales" be added immediately after the words "counters" in subdivision $(b)$ of specification No. 3.

The Acting Chamrin. The motion is to add the words "and graduated scales" in specification No. 3, section (b).

Mr. BARNARD. I second the amended motion.

(The motion was agreed to.)

Mr. Coney. The question of meters is omitted from the second paragraph. Just to make the point clear, meters are the registering device for the use of the dealer himself, and the individual buyer has no interest in them. That is the purpose, is it not, of the specification as written? As a matter of fact, the meters on a very great number of pumps are purposely covered, because the dealer prefers to have it so.

The Acting Champman. Such as a cash register.

Mr. CoRer. Just the same; but the counter or graduated scale is for the use of the individual buyer. I want to have that point clear.

The Acting Chairman. The counter I have reference to registers the individual delivery only. That is what I assume to be a counter. What is ordinarily called the meter is a registering device for the benefit of the dealer.

(There being no further discussion, a motion to adopt specification No. 3, subdivisions $(a)$ and $(b)$, as amended was duly made and seconded, and the motion was agreed to.)

Mr. Schlink (reading) :

4. Units of delivery.-Liquid-measuring pumps shall have the following discharge capacities per stroke or cycle, and these only: One gallon, a multiple of the gallon, or a binary submultiple of the gallon; that is, a quantity obtained by dividing the gallon by the number 2 or a power of the number 2: Provided, however, That a pump may be constructed to deliver other amounts than the above corresponding to predetermined prices at a definite price per gallon, but in such cases the pump shall be so constructed that the price per gallon at which it is set at any time and also the amount actually delivered must be clearly indicated.

Mr. Holbrook is the author of that specification and can describe it better than $\mathrm{I}$.

Mr. Houbrook. The specification is necessarily supposed to be selfdescriptive. If there is any doubt about its meaning, I will be glad to discuss it.

(There being no further discussion, a motion to adopt the specification as read was duly made and seconded, and the motion was agreed to.)

Mr. Schlink (reading) :

5. Closure of one outlet.-When two discharge outlets fne the liquid are provided on a liquid-neasuring pump, the pump shall be so designed and constructed that one outlet must be tightly and completely closed off whenever the other is open, so that no liquid can be discharged excent through that outlet which is in use at the time and for the purpose intended. 
That is intended to guard against the possibility of having two pipes leading from the pump, as is often the case, with the danger that when one valve is in use the other may be slightly open and thus permit part of the gasoline to be diverted from the purchaser's car into some other pipe line.

Mr. Stewart. Am I to understand that that specification, No. 5 is to apply to all pumps? If so, what are we going to do with some already in use? I want you to think about that.

Mr. Houmsoor. The pump which is already in use which is incorrect or which facilitates the perpetration of fraud should be at once condemned.

Mr. Barnard. I more that specification No. 5 be arlopted as read.

(The motion was seconded and agreed to.)

Mr. Schlink (reading) :

6. Mrainatge of discharge pipin!- $(a)$ All liquirlmeasuring pumps used for the sale of gasoline shall be so constructed as to provide for the complete and rapicl drainage, to a definite and uniform level of the liquid contained in the lrose or outlet pipe. This specification will be construed to require that hose. if used, shall be of such length and stiffness and its inlet end at such height ibove the normal lerel of its discharge end, when used for the purpose of delivery to an automobile fuel tank, that no movable portion of the hose will be disposed in such a way as to tend to retain liquid after the operation of the pump is completed.

(b) All liquid-measuring pumps shall be so designed and constructed that they will not permit a siphoning or a continuous trickle of liquid from the discharge outlet after the operation of the mechanism is discontinued. All liquidmeasuring pumps which under the foregoing specification are required to be equipped with a standpipe shall be furnished with a vacuum breaker or equivalent device adapted to cause the definite, immediate, and rapid drainage of the downcoming portions of the hose or pipe.

NOTE.-A standpipe shall be defined as any elevated pipe designed to connect with the upper end of a hose or other movalble delivery tube and intended to insure rapid and complete drainage of such delivery tube into the tank or vessel into which liquid is being discharged.

Mr. Barnard. I am wondering in reference to this particular specification if it would not be advisable to specify a reinforced hose. I have found in my experience a great deal of trouble with hose that might be sufficiently long and might appear to be sufficiently stiff, but where there was no reinforcement inside the hose, and, consequently, the rubber expanded from contact with gasoline, the inside diameter became smaller, and it was impossible to get the fluid out. Language should be placed in the specification to indicate that the hose shonld he reinforced.

I move that Mr. Schlink prepare language in keeping with this specification according to that theory.

Mr. Stimpsox. I second the motion.

The Acting Chamman. It is moved and seconded that Mr. Schlink insert words in this specification relating to hose.

(The motion was agreed to.)

Mr. Stewart. That specification will do away with the valve on the end of the hose?

Mr. Holbrook. Yes, sir.

Mr. Stewart. I am glad of that.

Mr. Coney. That is contrary to some regulations as to safety and insurance.

The Acting Chairaras. We will pass from this section until Mr. Schlink prepares an amendment. 
Mr. Schlink. I think we had better pass on it now.

Mr. Stewart. If this disagrees with some of the insurance laws, we want to think about it. I am not objecting to it. I am in favor of it; but how about the insurance laws of the States?

Mr. Schlink. It is only proper to say that in the past the insurance men have led in the regulation of gasoline pumps and left the weights and measures men to take what is left. I think we ought to take the stand that accuracy is on a parity with the fire-hazard question. We can get together with the insurance agencies and come to an agreement on these points. I do not think there will be any difficulty on that.

Mr. HoLbrook. We all know that in every jurisdiction tliere are a very large number of pumps in use which do not have any cut-off at the end of the hose. If these are in conflict, how do those get by these insurance laws now? How do they violate the law and what form cloes the law take? Would the insurance people prefer to have the hose filled with gasoline to an empty hose? Would that reduce the hazard?

Mr. Coper. I think it is a law of the city of Detroit, for example.

Mr. Holbrook. Have you in use in Detroit, Mr. Austin, a number of measuring pumps which do not have a cut-off at the end of the hose?

Mr. Austix. Yes, sir; we have quite a number of them. Numerous installations are now going in and have been for the past six or eight months, and nearly all are with the character of delivery pipe specified here.

Mr. HoLbrook. If we have a very large number of pumps in those cities which have no cut-off at the end of the hose, and if it is the sense of the conference that there should be no cut-off at the end of the hose, what is the objection to providing such a specification?

Mr. Corer. I was only speaking of the city regulations which prevail at certain places. There are several times as many shipments made from our factories with the open-end hose than with the shutoff. These shut-off valves are being sent to those localities where the ordinance requires it. I think the manufacturers would all prefer to see the open end, as it gives the best results.

Mr. Holbrook. Is it considered safer to have the hose filled with gasoline rather than empty?

Mr. Schinк. I find this particular point is material in a later specification, in which only one shut-off cock is allowed in the discharge line. It is not germane to the present discussion, but has done no harm.

Mr. Holвrooк. It will not be necessary to discuss it later. Do you know, Mr. Corey, whether such an insurance regulation is written? Do you yourself think that the fire hazard is less with the hose filled with gasoline than when it is empty? I can not see why such a regulation should be in force, nor am I familiar with such a regulation.

The Acting Chairman. There is one exception, Mr. Holbrook. In Massachusetts, we insist that a hose shall be drained at all times, but there is one exception; that is in the case of a certain metering device. In this the meter commences to register as soon as the valve at the end of the hose is opened, and when the proper registration is reached the valve is closed. That is the only device in Massa- 
chusetts where we allow the hose to be filled. I can see no other way to dispense gasoline from that type of measuring device.

Mr. HoLbrook. If the purchaser can spot his car so that the valve at the other end of the pipe can be reached, would not that be satisfactory?

The Acting Chairman. What other end?

Mr. Houbrook. There are two ends to the hose and you are required to have the valve at the end of the hose near the pump. Why can not a valve be placed there?

The Acting Chairaran. I have taken it up with the manufacturer, and in the case of that particular type of device it is impracticable.

Mr. Holbrook. Why?

The Acting Chamman. I can not give you the scientific reasons. I will be glad to mail them to you.

Mr. HoLbrook. I have never considered it was impracticable.

The Acting Chairman. I wrote to the Bureau regarding this, and the reply was that my contention that the hose should be filled was practically upheld.

Mr. HocbrooK. No; not at all. We said that we saw no reason why a valve should not be placed at the pump end of the hose. That is far from upholding your contention. We saw no reason why the valve should be placed at the nozzle.

The Acting Chairman. Particularly on this hydraulic-pressure pump?

Mr. Hocrnook. Equally on the hydraulic-pressure pump.

The Acring Cramiran. That is the point I made, and when I got your letter that was the interpretation I put upon it.

Mr. HoLbrook. You did not need to interpret the letter. The letter said "No."

(There being no further discussion, a motion to adopt the specification as amended was duly made and seconded, and the motion was agreed to.)

Mr. SchlinK (reading) :

7. Sensitiveness.-All liquid-measuring pumps of whatever type used in retail trade shall be so designed, constructed, and graduated that their indications can be read or their discharge readily determined within an amount which is not greater than the value of the tolerance as hereinafter provided.

In connection with this specification, it was found not sufficient to define the accuracy and establish a tolerance, since it was impossible to read the tolerance on many pumps.

(There being no discussion, a motion to adopt the specification as read was duly made and seconded, and the motion was agreed to.)

Mr. Schlink (reading):

8. Conipletcness of delivery before indication.-(a) On all defined-stioke, piston-type, liquid-measuring pumps, the construction shall be such that a counter or indicator will indicate clearly and definitely such discharge, and only such discliarge, as lias actually been completed by the pump proper; that is, the indication of each unit of discharge shall take place only when such full discharge from the measuring cylinder has in fact occurred.

(b) Any such counter or tallying device as is required under the specification shall be so constructed that its dial or pointer is returnable readily to a definite and clear zero reading before the next delivery is begun.

(There being no discussion, a motion to adopt the specification as read was duly made and seconded, and the motion was agreed to.) 


\section{Mr. SchLINK (reading) :}

9. Pointers and indicators.-All pointers and indicators used on counters or computing attachments or other legistering parts shall be so shaped that a correct and accurate reading is given. Pointers are required to be symmetrical about the graduation lines at which they may stand, and blunt-endes types of pointers shall not be used.

(There being no discussion, a motion to adopt the specification as read was duly made and seconded, and the motion was agreed to.)

Mr. SchlivK (reading) :

10. Lettering, graduations.- $(a)$ All markings, instructions, and graduations required under these specifications shall be of such size, design, and location that they will not tend to become obliterated by dirt or oil, or for any other leasons tend easily to become illegible.

(b) The graduations shall be of such character and arrangement that the major ones are clearly distinguished from the minor ones.

We find in some cases that the graduation marks become incased with material or filled with lubricating oil, and you can not read them after a month or so.

Mr. Holвrook. I move that the specification be adopted with the word "distinguishable" inserted in section (b) in lieu of the word " distinguished." If we want them distinguishable, we must say so.

(The motion was seconded and agreed to.)

The Acting Champan. Where is No. 11?

Mr. Holbrook. A typographical error has been made. We must subtract one from each of the numbers until the extra specification is reached. That will adjust it.

Mr. SchlinK (reading) :

11. Scales in opposite directions prohibited.-The use on a liquid-measuring pump of two graduated scales reading in opposite directions and referable to the same pointer or liquid surface shall not be permitted.

(There being no discussion, a motion to adopt the specification as read was duly made and seconded, and the motion was agreed to.)

Mr. Schlink (reading):

12. Compuing charts.-The valne graduations on all computing charts used on liquid-measuring pumps shall not exceed 1 cent at all prices per gallon up to and including 30 cents. At any higher price per gallon the value graduation shall not exceed 2 cents: Provided, howerer, That nothing in the above shall be construed to prevent the placing of a special value graduation to represent each 5-cent interval. These special graduations may take the form of dots, staggered graduations, or similar forms. They shall be so placed that their meaning and value may be clearly understood, but they shall not be placed in the space between the regular graduations.

Mr. HoLвrook. That is lifted verbatim from the specification on computing scales. I think the same specification should apply here.

(There being no discussion, a motion to adopt the specification as read was duly made and seconded, and the motion was agreed to.)

Mr. Schlink (reading) :

13. Exhaustion of liquid supply.-All measuring pumps of which the accuracy of delivery is affected by the lowering of the liquid in the supply tank to a point at or near the intake end of the suction pipe shall be provided with a device which will make the pump inoperable during the continuance of this condition, or shall be so constructed as to warn the purchaser and the operator in a conspicuous and distinct manner that the lerel of the liquid supply is so low as to endanger the accuracy of the measurement. 
Mr. YAKE. Is it intended that a device shall be supplied, in addition to a guage stick, to enable the user to determine when a tank is empty or nearly empty?

Mr. Schlin K. Yes, sir.

Mr. Stewart. A device in addition, not only for the user, but for the purchaser.

(A motion to adopt the specification as read was duly made and seconded, and the motion was agreed to.)

Mr. Coner. May I ask for information regarding that? I do not know just what action will be taken. Are the men going out from this conference to put into effect these specifications; and if so, does that mean they are going to put two or three million gasoline pumps out of business right away? I do not know of any such device; possibly you would get it.

Mr. Bean. I do not know of any such device now on the market. The only thing I can think of would be a float. In many cases the storage tank is a considerable distance from the pump. Perhaps the pump is located on the curb, and the tank is underground back of the garage. It would certainly not show under these conditions unless controlled electrically. That would bring electrical contact into the tank, making an extremely dangerous condition.

Mr. Barnard. Mr. President, I think Mr. Schlink's contention in that respect is wise. I know we have had much trouble with gasoline being delivered from nearly empty tanks, and I think this anticipated regulation is certainly fine, and the quicker a provision of this kind is put into effect the better it will be for the ultimate consumer.

$\mathrm{Mr}$. HoLвRоoк. Is there such a device on the market?

Mr. Schlink. Not as far as I know.

Mr. HoLвкоок. I move that that specification be starred until such time as it is practicable to put it into effect. We declare, however, that it is the opinion of this conference that this should be complied with, and we will suggest to the manufacturers here, and throngh the record to other manufacturers, that steps be immediately taken and investigations begun which will ultimately result in the perfection of such a device.

Mr. Scmlixk. It is proper to say in this connection there is no device, so far as we know.

When a man purchases from an empty tank or nearly empty tank he almost always gets short measure. There is no reason why that should not be corrected. I have nyself seen three or four deliveries made from a tank in which the suction pipe was so nearly uncovered that every time the stroke was made the gasoline would back down to the pipe, and there would be too much aspiration of air. The user of that pump may not have known it. I think he should have been able to ascertain it by the way the pump operated, but he had no other means of knowing it.

The Acring Chairman. The motion before the house is that the enforcement of specification No. 13 be delayed until such time as the device has been perfected.

Mr. Stewart. This places us in West Virginia in a rather peculiar position. I had a bill put through our last legislature providing that all regulations issued by the Bureau of Standards at any time should immediately become effective in our State. We depend upon 
them to tell us about these regulations and specifications. It does seem to me there ought to be a date set if we can, say a year or something of the kind, so when these specifications go out to the States we will know when they will be in effect.

Mr. HoLbrook. We can not very well date the enforcement of a specification which is to go into effect at some time in the future. We can not very well date the time of enforcement when we do not know how soon practicable devices may be evolved. If the conference passes this, the work will be started. At any rate, if we are to follow out the suggestions which the Bureau has made, that these specifications are tentative and are only to be enforced in so far as they are found practicable to be enforced, you are supposed to state your difficulties in order that we may adopt a final set of specifications next year. Is it the sense of the conference that that procedure shall be followed?

The Acting Chairman. Please state the motion made.

Mr. HoLbrook. I make a motion to the effect that the specification under discussion be not retroactive on any pump, and, further, that it is not to be put into force by weights and measures officials until it has been demonstrated that there are devices on the market which will properly take care of the subject matter of this specification. Further, this conference calls the attention of the gasoline-pump manufacturers to this specification, and gives notice to the pump manufacturers that something like this is very much desired, and that if proper steps are taken to get devices like this on the market they will not be disturbed by the enforcement of this regulation at some future date.

(The motion was duly seconded, and was agreed to.)

Mr. SchurNK (reading) :

"14. Use limited to certain liquids.-Liquid-measuring pumps which will not give correct results except when used with liquids having particular properties, as, for example, high viscosity, shall be conspicuously, clearly, and permanently marked to indicate this limitation. Such wording may take the form, "Not suitable for gasoline or light oils," "Use only for molasses and heavy oils," or "For viscous liquids only."

As to the point involved in that, it has been said that when the gasoline pump is being used for a different kind of gasoline than it was adjusted for, or when it is being used for gasoline when it was built for kerosene or what not, then you can not expect it to be accurate. This really requires that the manufacturer shall accept the responsibility of stating the kind of liquid for which the pump may be properly used. Then, when incorrectly used, the fault can be brought home to the fellow it fits, whether dealer or manufacturer.

(There being no further discussion, a motion to adopt the specification as read was duly made and seconded, and the motion was agreed to.)

Mr. CoREr. As a matter of information, one of the principal reasons for thus marking the pumps, which may not have occurred to you, is that certain metals or finishes are necessary for the handling of certain liquids. I just suggest that so you will not be confused as to differences in pumps for different liquids. It may be due solely to the materials of which the pump is made. 
Mr. Schlink (reading) :

15. Provision for sealing.-All devices adapted to be altered for adjusting or correcting the delivery of a liquid-measuring pump shall be of such construction that they can be sealed, either separately or together, in such a manner that the position of none of them can be changed without destroying the seal ol seals: Provided, houever, That this shall not apply to such devices as alter the price, and consequently the delivery, of such a pump as is described in the proviso of specification No. 4.

Mr. Austrn. I move to strike out the provisions of that number.

The Vice President. Mr. Austin moves that we strike out the whole section-section 15.

Mr. BuCK. I second the motion.

Mr. Schoenthal. May I ask why? There is no reason given.

Mr. Austin. For the reason that up to this time, as far as my experience goes, there has been no pump found that would maintain its permanency for any feasible time, and this method of sealing them would prevent the user of the pump from interfering with or readjusting his pump so that it might give reasonable accuracy in its delivery.

Mr. Schlink. This matter is more fundamental than the question involved in specification No. 15. It becomes a question of whether or not a gasoline pump is a measuring device. If it is a measuring device, it ought to be sealed, if we are to give it any credence at all. Our idea in preparing the specification was that if it is a measuring device, seal it and give the consumer protection. The matter of permanence of accuracy is covered in the previous specification, which covers maintenance of accuracy of the pump when it is correctly adjusted. If you reject specification No. 15, you are rejecting the whole matter of leaving the measuring pump under the jurisdiction of the sealer of weights and measures in so far as it becomes a device available for use in trade. Am I right, Mr. Holbrook?

Mr. HoLвRook. Yes.

Mr. Stimpson. It seems to me this practice of leaving pumps unsealed could very well be retained in any definite locality; if any sealer does not think it is practical to seal the pump, he need not do so.

The Acting Chairman. The motion before the house is that the entire section be rejected. Those in favor of rejecting say "Aye"; those opposed to rejecting "No."

(The motion was rejected.)

A motion to adopt is in order.

Mr. BARNARD. I move that specification No. 15 be adopted.

(The motion was duly seconded and agreed to.)

Mr. Schlink (reading):

16. Stops to be positive.-When the stops or other stroke-limiting devices on a liquid-measuring pump are subject to direct pressure, or impact, in the operation of the pump, such stops shall be of such construction that the permanence and security of their positions are not solely dependent upon friction; that is, under the conditions designated, the construction must provide for a positive, nonfrictional engagement of the parts whose relative motions are to be prevented.

This is to prohibit the use of stops held by set screws moving on a rod or any similar arrangement which will permit the continual hammering of the stroke to slide the stop along the rod. Anything 
that could happen in this way would increase the delivery of the pump, it should be said.

(There being no further discussion, a motion to adopt the specification as read was duly made and seconded, and the motion was agreed to.)

Mr. Schlink (reading):

17. Graduated parts secured.-When a liquid-measuring pump is provided with a scale of graduations to indicate or adjust the amount to be delivered, this scale shall be riveted to its support or otherwise permanently fixed in position: Provided, however, That in the case of measurlng pumps of the gauge-glass type, a sliding scale will be permitted when the displacement of such scale is, by suitable mechanism, automatically prevented at all times when liquid is being discharged from the delivery outlet.

The reason for that is obvious. If a man moves the graduated scale at the time delivery is being made you do not know what he has done to the final indication.

(There being no further discussion, a motion to adopt the specification as read was duly made and seconded, and the motion was agreed to.)

Mr. Schlink (reading) :

18. Diversion of measured quantity.-There shall be no direct or continuous connection or device adapted to return any portion of the measured liquid from the discharge pipe or outlet of any liquid-measuring pump to the supply tank or pipe of the same. All valves in the suction line which are intended to prevent the reversal of flow of the liquid must be of such design that their closure is automatically effected in the use of the pump.

Mr. BARNARD. I think we should give this specification careful consideration. In the matter of visible pumps, the underwriters have a provision that gasoline which is in the container should be returned to the tank when the pump is closed for the day. I believe, and it was the consensus of opinion of the Michigan delegation in their conference, that there should be an automatic device for returning that gasoline to the tank in the case of visible pumps. This specification would not cover that, in my judgment.

Mr. HoLвRоoк. I think the words "from the discharge pipe or" outlet" are significant there. I take it that the gasoline can be returned to the tank provided specification No. 5, which is already adopted, is fulfilled. 'This provides that when two discharge outlets are provided the pump shall be so designed and constructed that one outlet must be completely closed off whenever the other is open.

Mr. Barnard. I think our phraseology in that respect should be absolutely clear, because it might be construed otherwise by some sealer who may not have the same thought and technical idea Mr. Holbrook has just presented. If the phraseology of that particular specification were to be clarified, I believe it would be better in practice.

The Acting Chatrman. That, probably, can be done.

Mr. Schlink. It would be well if you indicate what idea you wish to comprise in the first sentence. I take it the second sentence is all right.

Mr. Barnard. My idea is to make that particular specification clear and provide for an antomatic derice which will allow the gasoline in the visible container to be returned to the tank in compliance with the underwriters' regulations. 
Mr. Holbrook. What do you mean by automatic?

Mr. Barnard. It is done by the closing of the door, so it can not be done by the man in operating the pump at any time. If there were a device so a man could turn a valve or cock and return gasoline to the tank while the gasoline was going to the car, it would give an opening for short measure.

Mr. Holbrook. It is provided in specification No. 5 that while gas is being delivered to the car. it can not be delivered any place else:

5. Closure of one outlet. -When two discharge outlets for the liquid are provided on a liquid-measuring pump, the pump shall be so designed and constructed that one outlet must be tightly and completely closed off whenever the other is open, so that no liquid can be discharged except through that outlet which is in use at the time and for the purpose intended.

Mr. Barnard. I think it ought to be clearly specified that it should be an automatic arrangement.

Mr. Holbroor. You mean that we should require it to be an automatic arrangement? How about letting the fire underwriters' association take care of that?

Mr. Barnard. Why pass the buck to them? Why not do it ourselves?

Mr. Holbrook. Because the fire underwriters are going to make their regulations for safety arrangements requiring that it be automatic.

Mr. Barnard. That would be a safeguard from short measure, too.

Mr. Holbrook. I do not see how. If we have covered that matter when the gasoline is going into the car, have we not covered the matter completely? The fact that it be automatically returned to the tank is pure safety, is it not? Is there any accuracy requirement there?

Mr. Barnard. If they put a valve or cock on that pump which is operated by hand, they comply with specification No. 5, do they not? The gasoline could not go into the tank unless that was open.

Mr. Holbrook. Right.

Mr. BarNaRD. What is to prohibit them from turning the opening a little bit more, so while it is running into the car some will be returning to the underground tank?

Mr. Holizook. Because one must be closed before the other can be opened.

The Secremary. You can not always tell what is going into the car. It might run into the tank, while you think it is running into the car.

Mr. HoLвrook. If any man while delivery is going on turns the valve on the pump, it is up to the purchaser to see that. At Mr. Barnard's suggestion he would close the door which would be very much less obvious than the turning of the valve. Of course, he can turn a valve and retain part of the gasoline in the pump, but if he deliberately shuts off a valve the purchaser is on his guard.

Mr. Barnard. There is a very great objection in Michigan to that specification. It is a matter that was not clearly understood.

Dr. Reichmann. I think Mr. Holbrook's contention is right. $\mathrm{He}$ has covered that whole proposition of section 18 fundamentally, that when you deliver the gasoline from the device all of it must go to the place intended. The automatic return is purely a safety proposition. I think if you butt in on that, you butt in on the fire under- 
writers. The project brought up earlier in the day involved measurement and certainly you could not get much clearer English than that written in the former.

You can not put up to 16,000 firms the procedure that you want; it would not be perfected in 1920 .

Mr. Bean. I was wondering if in specification No. 5 the word "automatic" could not be inserted after "must," so as to read "one ontlet must be tightly and completely closed," etc.

Mr. ScrulNk. I move the insertion of that word.

The Vice President. It is moved and seconded.

Mr. W. S. Townsend (representing Guarantee Visible Measure Sales Co.) I think, perhaps, that the proposition you are trying to accomplish here is to prevent the return of liquid to the storage tank at the time it is being delivered to the car. The solution to the question of whether or not the outlet to the tank, if there be one, is closed or not is to have that outlet above the surface of the liquid, so that no liquid can run out. If, for instance, you should insert the phrase "should be automatically closed," I think the provision would be so broad that it would prevent a mechanical device being built to take care of your proposition and absolutely accomplish what you want to accomplish. I would, therefore, suggest that you make the wording so clear that it would permit the accomplishment of your purpose in a manner agreeable to the machinery manufacturer's.

Mr. Barnard. We have specified how it must be done. It must be done automatically.

The Acting Crampman. The question before the house is on the insertion, in specification No. 5, of the word "automatically" after the words "one outlet must," so as to read, "one outlet must automatically be tightly and completely closed," etc.

Mr. HouBroor. Why "automatically"?

Mr. Scrruin. Mr. Barnard said that would obviate his objection.

Mr. Houbrook. Suppose it is done by manual means. In other words, suppose we have a two-way valve so that one way must be completely closed before the other opens.

Mr. Scmulnk. That is fully automatic.

Mr. Holbrook. I take it he made it automatic by the closing of the door.

Mr. Barnard. That was the suggestion.

Mr. HoLbrook. Is a two-way valve operated automatically or manually?

Mr. Schlink. A two-way valve one opening of which can only be open at one time. Is there objection to it?

Mr. HoLbrook. Entirely satisfactory.

Mr. W. S. Townsend. What do you mean by "tightly closed" ?

Mr. Schink. If there are two pipes leading out from the pump, as in some pumps with a filling outlet alongside of the hose ontlet, this would require that when one is open the other must be closed.

Mr. WV. S. Townsend. Do you mean ontlet to the car or to the tank? What do you mean?

Mr. SchulN K. No liquid may be discharged except from that outlet which is in use at that time. This would prevent any device on the pump that would permit more or less to be diverted back to the tank or diverted to any other delivery point while gasoline is being delivered to the car. 
Mr. W. S. Tow xsmp. Suppose the opening in the container-I am speaking of the risible type-mere abore the lerel of the gasoline in the container. would that accomplish your purpose?

Mr. Schlix K. It would, provided it were automatically maintained in that position during the time the other valve was opened.

Mr. IV. S. Towrsend. That specification was written with the closing ralve in mind, but you say outlets must be tightly closed. I say the purpose can be accomplished by lifting the outlet.

Mr. Schlisk. If the open outlet is at the top of the liquid in the pump you speak of, I can still discharge liquid from the pump by operating the level adjuster. Does that answer your question?

Mr. IV. S. Townsexd. Suppose, then, that you fix this adjusting rod so it can not be lomered?

Mr. Schlisk. That would comply, I think, since you could not get liquid back through it.

The Actixg Chairirax. Tro motions have been suggested to the house. The first is on the adoption of section 18 as read.

(The motion was agreed to.)

The Acrisg Chammax. The next motion is to insert the word "automatically" "after the word "must," in specification No. 5, so as to read:

When two discharge outlets for the liquid are provided on a liquid-measuring pump, the pump shall be so designed and constructed that one outlet must automatically be tightly and completely closed off whenever the other is open, so that no liquid can be discharged excent through that outlet which is in use at the time and for the purpose intended.

(The motion ras duly seconded and agreed to.)

Mr. Schlink (reading):

19. Only one shut-off cock permitled in discharge line.-No more than one shut-off ralve or cock, intended to be operated by hand for the purpose of cutting off the flow of liquirl, shall be permitter in the discharge line of a liquidmeasuring pump, and in the case of liquirl-measuring pumps with which hose or other movable delivery tube is used or which require the use of a vacuumbreaking valve or equiralent derice, ans shnt-off valve shall be located as near as possible to the pump itself, and not in the hose line or at the extremity of the hose.

(There being no discussion a motion to adopt the specification as read was duly made and seconded, and the motion was agreed to.)

\section{Mr. Schlixk (reading) :}

20. Protection against corrosion.-In the case of liquid-measuring pumps which depend for the accuracy of theil measurement upon the tightness or perfection of seating a ralve or valres, the material used for tanks, piping, and all such auxiliary apparatus as may contain liquid, including the pump itself, shall be of such nature and properties as to be free from the likelihood of corrosion or rusting or the liberation of particles which will be likely to impair the tightness or correctness of seating of such valves.

(There being no discussion, a motion to adopt the specification as read ras duly made and seconded, and the motion was agreed to.)

Mr. Schlix (reading) :

21. Limiting height of suction lift.-No defined-stroke, piston-type, liquidmeasuring pump shall be so installed as to work under a total suction head sufficient to cause vaporization of the liquid for which it is used under the highest temperature and lowest harometric pressure likely to occur. 
It is inevitable that this specification should be somewhat vague in its terms. That is, it is impossible to name the particular height of lift, because it depends upon the gasoline used, and it will be up to the locality to determine for itself or by application to the Bureau of Stamdards in the case of the particular gasoline in question. We have found that in the case of the ordinary gasoline sold here in Washington a suction lift of 7 feet may actually be feasible. There are gasolines, which you all know, that you can not lift at all by suction, such as those that will boil off at ordinary temperature. This is intended to be broad enough to cover the whole range of possibility.

(There being no further discussion, a motion to adopt the specification as read was duly made and seconded, and the motion was agreed to.)

Mr. Scrumk (reading):

22. Use of adjustments.-(a) No adjustment of the delivery of a definedstroke, liquid-measuring pump shall be permitted, except that intended to proluce a piston displacement per cycle of 231 cubic inches per indicated galion of delivery.

(b) Adjustments of piston displacement to correct for leaks, slippage, excessive length of pipe line, or other defects of the installation shall not be permitted.

This seems absolutely called for by the adjustment conditions that obtain in the field. The installation men and repair men will change the adjusting stop on a gasoline pump for anything that is wrong from a slight leak to a broken pipe line. They have a queer idea that the only thing the adjustinent is for is to make that piston generate a volume equal to a gallon when it moves a stroke.

Mr. CoREx. This gets back to the previous paragraph: What happens when the user has been using straight-run gasoline satisfactorily and then operates with another gas?

Mr. Schlink. He is likely to change adjustment of the piston, but he should not do it.

(There being no further discussion, a motion to adopt the specification as read was duly made and seconded, and the motion was agreed to.)

Mr. Schuin K (reading) :

23. Stop mechanism to be definitely positioned.-All stops which define the delivery of a liquid-measuring pump shall be clearly and conspicuously marked to indicate the value of discharge volume to which they correspond, and any device intended to vary the discharge by bringing different stops into operation shall be so designed and constructed that it is brought to a definite and accurately defined position and that inadvertent displacement from that position will be obstructed.

(There being no discussion, a motion to adopt the specification as read was duly made and seconded, and the motion was agreed to.)

Mr. SchuINK (reading):

24. Position of operating handle--(a) In all defined-stroke, piston-type, liquid-measuring pumps the initial or starting position of the operating crank or handle shall be defined by a latch or snap which will operate to hold the handle accurately in that position when the apparatus is not in use.

(b) The initial position of the handle on all types of defined-stroke, pistontype, liquid-measuring pumps shall be vertically downward. Handles which in their starting positions are inclined to the vertical or stand vertically 1 pward shall not be permitted. 
Mr. Coner. I would like to ask why the second sentence?

Mr. Schurk. It is a matter of custom with a large proportion of measuring pumps to have the handle started in that position, and customers and garage men are accustomed to that position. I have seen measuring-pump handles that were deliberately placed off the vertical. In operating the pump the operator could bring it back and stop at the vertical position without hitting the lower stop and next time he would start from that position and deliver short measure to the extent of 20 to 30 per cent without your discovering it.

Mr. Coner. There are pumps in which only a portion of a revolution will give this full half stroke, and it is not convenient to start them from a direct vertical position.

Mr. Schlink. That may be true, but it seems to he necessary to safeguard the purchaser to the extent that he shall get full measure from a position where the handle is commonly supposed to start.

Mr. Corey. I can not see how that accomplishes this purpose.

Mr. YAke. There are types of pumps on the market where the lug is disengaged from the piston. How would this specification apply to those pumps? The handle is free.

Mr. Schurnk. Then the handle should engage the lug when in the position specified.

Mr. YAKe. It does not engage at all. How would the specification apply to that?

Mr. Schlink. That is a difficult question to answer; I admit it freely. I do not know whether that type should be permitted when it comes to that question. Perhaps it facilitates the perpetration of fraud.

Mr. YA Kr. On the other hand, the type is such that it prevents it.

Mr. BeAn. I beliere there are one or two pumps on the market in which the handle is in a vertical upward position. Otherwise it is impossible to lock it.

Mr. Schums. I admit it might require a modified handle.

Mr. Bean. What would be the result with these pumps now in use? Would they have to be condemned?

Mr. Schurn. It becomes a matter of policy of enforcing the regulations.

Mr. HoLвRook. I would say in relation to all these regulations that if in the sealer's opinion a specification is here written which will tend to improve the type, but which is not aimed at preventing the perpetration of fraud at the present time, then, in the case of such a specification, it need not be applied to apparatus in use at the time these regulations are adopted.

The Acting Chairman. In other words, these specifications will not be retroactive?

Mr. HoLbrook. Those will not be retroactive which in the judgment of enforcing officials are not absolutely required to prevent the perpetration of fraud. If a specification is put in here which the official believes tends to eliminate a pump which at the present time facilitates the perpetration of fraud, we suppose that ought to be retroactive and affect the pumps in use at the present time. If the specification is such that it will tend to improve the types of 
pumps in the future, but the present type is not one which makes easy the perpetration of fraud with the pump as installed, then we think the specification should not be retroactive and should not affect the pumps in use at the time the specifications will be adopted. The only reason some of these were not starred as in the specifications for reights and measures of other types is that they are tentative, as I have emphasized.

If it is found that some of them would be detrimental to some interests without accomplishing a good purpose for the consumer, then the official should not enforce those particular ones.

Mr. Coner. The point I made is that I fail to see how this particular position of the handle accomplishes the desired end. If the moving of the handle, for example, brings about a condition such as described by Mr. Schlink, the moving of the handle on the shaft would accomplish the same thing under this condition, and even more so, because the purchaser is then depending upon the position of the handle to indicate whether the pump is properly set as delivery begins, that being the case, nothing has been accomplished, and it upsets a whole lot of work done upon thousands of pumps now used at the present time and being manufactured constantly.

Mr. Schlink. The only answer to that question is to ask another one. How is the consumer to know when the stroke has been completed?

Mr. Coney. That is a matter of stopping in a particular position of the handle.

Mr. Schlink. He does not feel that stop. The operator feels it. There is no noise in connection with it even. You may see the handle stop sharply, but, on the other hand, the operator who is deliberately perpetrating fraud can easily so operate the pump as to give the impression of having reached the end of the stroke. I have seen it done, and this is merely attempting to add a visual index to the purchaser of the stroke being completed. It simply complies with the custom obtaining in the trade at that time.

Mr. STEwart. I would suggest that instead of regulating the position of the handle there be something to give a signal when a stroke is at the bottom or at the top, so arranged that it will not give that signal unless the complete stroke is made. That could be done and done easily.

Mr. Schumk. It is proper to say: Mr. Stewart, that we considered that too radical a proposition, since it would require a much wider range of reconstruction of pumps than this.

Mr. Stewart. That can be done by simply having a little bell.

Mr. Schlisk. But it would require reconstruction of every pump. This would permit existing pumps to pass in large numbers, because many of them are so constructed.

A Menber. I can make you one that can be attached to every pump in the field.

The Acting Chairman. The motion is on the adoption of specification No. 24.

(The motion was agreed to.)

Mr. SchurNK (reading):

25. Tolerances.-The tolerances to be allowed in excess or deficiency on all liquid-measuring pumps shall not be greater than 1.8 cubic inches per indicaterl gallon: Provided, houcver, That the manufacturers' tolerances or the toler- 
ances on all new liquid-measuring pumps shall not be greater than one-half of the values given above: And provided further, That these latter tolerances shall also be applierl to all pumps which are being retested after being found incorrect and subsequently adjusted or repaired.

Mr. Ноцввоок. I think it is fair to point out that this tolerance is changed, as stated in the remarks which I made earlier in the morning.

(There being no discussion, a motion to adopt the specification as read was duly made and seconded, and the motion was agreed to.)

Mr. Schlink (reading):

26. Constancy of delivery.-The amounts delivered shall not rary by more than the tolerances provided above, irrespective of the speed at which the apparatus is operated and irrespective of the time elapsing between operations, provided that, for the purpose of test, the conclition of the apparatus shall be such that a minimum period of nonuse of 24 hours shall not result in an error of the first delivery of the punip after such period of nonuse greater than the tolerance allowable.

NotE.-In applying the above specifications, errors due solely to a change in the rolume of the contained liquid resulting from temperature variations alone are to be eliminated, since an error of this character is unavoidable in the case of volumetric measurements of this kind when the apparatus is standing unused. This change in volume due to temperature rariations is, however, small in amount for all ordinary variations of temperature, amounting to about 0.7 per cent for ench $10^{\circ}$ is. change of temperature (or about 1.3 per cent for each $10^{\circ} \mathrm{C}$. change of tempelature).

Mr. Barnard. Is that a physical possibility relative to having the pump corrected after standing 24 hours?

Mr. Stewart. I suggest that that item be laid on the table.

Mr. HoLBrook. I desire to amend that specification to the effect that the part beginning with the words "provided that," be starred with a note of explanation that sealers shall not consider that this is to be enforced rigidly and immediately, but that upon this point in particular data be gained for the instruction of the conference next year.

Dr. Reichmann. I second the motion.

Mr. HolвRоoк. I may say in addition, the question is asked, Is this a physical possibility? There is no question whatever about its being a physical possibility.

$M_{1}$. Schunk. I can say further that in questiomaires sent out inquiring as to whether this was physically possible every manufacturer of liquid-measuring pumps that was approached said "yes"; that every pump when it left the factory would hold gasoline for any length of time, and, furthermore, if there was not damage to the ralves, such as deposits of material upon them, they would continue to hold gasoline for any length of time.

Mr. HoLbroox. I doubt it that is practicable; few in use will stand a 24 -hour test.

Mr. Schlink. They tell me that.

Mr. HoLbrook. As you know, there have been new pumps installed in the Burean which were supposed to be in perfect condition for our tests that did leak, and the manufacturer of one, at least, explained to me that while they could make a foot valve that would hold gas for an indefinite length of time, such a foot valve, being very deep, created such a large amount of trouble in practice that they were trying to make a shallow valve that would come up to the prorisions of this specification. 
Mr. Yake. The majority of the troubles experienced with the valves, as we all know, is dile to the character of the liquid that they handle, and the minutest particle of dirt getting on the valve disk or seat allows the valve to pass gasoline. I think every man here will agree that it is impossible to hare this permanence test covered in a gasoline-pump specification.

Mr. HoLbrook. Are they so tight when they leave the factory that they will hold gasoline for 24 hours?

Mr. Yake. I would say the largest pump manufacturers in the country aim to do that.

Mr. HolBrooK. Do they do that?

Mr. YAKE. From the test imposed upon them I should say "Yes."

Mr. Holbrook. Are they rejected if they leak 6 cubic inches in 24 lours?

Mr. YAKE. They are rejected for less than that. They are rejected for any leak at all. The aim is to make them perfectly tight.

Mr. Schlin K. It does not make a great deal of difference for the purposes of this specification as to whether they fail by a few cubic inches in maintaining their tightness. IVe must have a line of demarcation between a tight pump and one rejected because the foot ralves leak. If it is impossible for a pump to be maintained absolintely tight for a long time. there must be some limit on the leak beyond which we shall not allow a leak to go. If adopted later on, it will lead up to a definite numerical system of what shall constitute a definite allowable leakage.

The Acting Chairian. The question is on the adoption of this specification No. 26 . Amendment was that, beginning with the word "provided" in the fourth line, it be starred.

Mr. Corex. Going back to the words "irlespective of the time elapsing between operations"?

The Actrag Chammas. The amendment is to star beginning with the rords, "provided that."

Mr. Houbrook. I now suggest that it carry back to the words " and irrespective" at the end of the third line.

The Acting Champun. The staring will start after the words "and irrespective."

Mr. STEWART. Will the star indicate delay?

The Acting Chairman. That it is not to be immediately enforcerl, and that data be collected for the next conference.

(The motion was agreed to.)

(There being no further discussion, a motion to adopt the specific'stion as amended was duly made and seconded, and the motion was adopted.)

Mr. HoLbrook. At this point I suggest that the specification passed over be numbered 27 and put in here.

Mr. Schlink (reading) :

27. Length of scalc on certain types.--In all gauge-glass or float-gauge types of liquid-neasuring pumps which have a graduated scale as the sole means of determining the anount of liquid discharged the length on the scale equivalent to the tolerance at any point must be readily appreciable when the character of the indicator and normal distance from the observer's eye is taken into consideration, and in no case shall this length be less than 0.04 inch.

(There being no discussion, a motion to adopt the specification as read was dnly made and seconded, and the motion was agreed to.) 
Mr. Schlink (reading):

28. Maximum value of minimum graduation.-The maximum value of the minimum volume graduation on all liquid-measuring pumps shall be 1 pint.

Mr. CoRer. Does that mean that gasoline punıps must measure 1 pint?

Mr. Schlink. They must be graduated to 1 pint.

The Acting Chairman. Do you think a 5-gallon-capacity tank should be graduated to deliver a pint?

Mr. Schlink. There are 8 pints in a gallon, 1 part in 40 . Your customer is paying $\$ 1.25$ for the 5 gallons. Tou are giving him a chance to read to the nearest 3 cents; that is not rery close, compared with what is expected of computing scales. These graduations are used largely in case a man asks for 5 gallons. finds his tank will not hold it, and says "Stop." At that time you have to read how much you have actually delivered to him; so you see this auxiliary scale on the tank is a means of estimating the actual delivery; not what he intended to get.

The Acting Chaman. A man goes to fill his tank, supposing he can take 5 gallons. They put the hose in and the pump is operated until he gets $4 \frac{1}{2}$ and finds his tank is overflowing.

Mr. Schlis . The question is how much does he pay? He has to read the indication to ascertain how much he is to pay.

The Vice President. Those in favor of the adoption of specification No. 28 say "Aye ;" those opposed "No."

(The motion was rejected.)

Mr. Schlink (reading):

29. Fraudulent construction prohibited.-All liquid-measuring pumps shall be of such construction that they are not designed to and may not be used to facilitate the perpetration of fraud.

(There being no discussion, a motion to adopt the spccification as lead was duly made and seconded, and the motion was agreed to.)

Mr. Schlink (reading) :

30. Metric system.-No specifications contained in the preceding pages shall be understood or construed to prohibit the sale or use of liquid-measuring devices constructed or graduated in units of the metric system.

The tolerances to be allowed on any liquid-measuring device constructed or graduated in units of the metric system shall be the same as those specifier on similar apparatus of an equivalent size or at an equivalent capacity in the customary system.

(There being no discussion, a motion to adopt the specification as read was duly made and seconded, and the motion was agreed to.)

Mr. HoLBrook. There is a repolt of the resolutions committec to come before the convention.

The Acring Chairiran. We voted to come back this afternoon.

The Secretary. I have a communication herc from the Wholesale Grocers' Association transmitting 30 copies of their brief prepared in regard to this wrapped-meat proposition introduced at this conference. We will distribute them as you go out.

Mr. Barnard. I make a motion at this time that as soon as we return to the convention after lunch we take up again the matter of the net-weight proposition.

The Acting Champan. The motion is that the question of netweight marking be taken up.

(The motion was seconded and agreed to.) 

W. SIMITH.

The Acting Chairman. The committee appointed by the chair is ready to report if it is the wish of the conference. In the absence of the chairman, I have been asked to present the report on behalf of the committee. The resolutions are as follows:

RESOLUTION IN RE DECIMAL-WEIGHT FLOUR BILL.

Whereas we, the delegates of the Twelfth Annual Conference on Weights and Measures, in convention assembled, appreciate the great confusion resulting from the sale of flours, meals, commercial feeding stuffs, and corn products put up in packages weighing 196 pounds and the inconvenient and arbitrary submultiples of this figure, namely, $98,49,24 \frac{1}{2}, 12 \frac{1}{4}$ pounds, etc.; and

Whereas even this series is not adhered to in the several States, inasmuch as packages weighing 96, 48, 24 and 25 , and 12 pounds are sometimes standardized by law instead of the correct subdivisions given above, thereby increasing the confusion: Therefore be it

Resolved, That this conference go on lecord as leartily indorsing the principle of the sale of the above-mentioned commodities by the bundredweight and the following multiple and subdivisions thereof, namely 200 pounds, and $50,25,10,5,4,2$, and 1 pounds, respectively. And be it further

Resolved, That this conference respectfully urge the Congress of the United States promptly to enact legislation embodying this principle.

Mr. Tucker. I nove you that the resolution as read be adopted.

(The motion was duly seconded and agreed to.)

Mr. Sмrтн (reading):

RESOLUTION IN RE FEDERAL SERIALIZATION OF TYPE. ${ }^{1}$

Resolved, That we, the delegates of the Twelfth Annual Conference on Weights and Measures in convention assembled, realizing the imperative need that exists for uniform regulations governing the type and construction of weights and measures and weighing and measuring devices used for commercial purposes throughout the United States, go on recold as heartily indorsing legislation designed to secure serialization of the type and construction of such apparatus by the National Bureau of Standards.

Mr. Barnard. I move the adoption of the resolution.

Mr. Stimpson. I second the motion.

Mr. Strwart. Are the committee referring to containers in which this stuff is to be packed and shipped?

Mr. Smrth. Weights and measures and weighing and measuring devices have reference somewhat to containers.

(The motion was agreed to.)

Mr. Sмrтн (reading) :

RESOLUTION IN RE SALE OF COMMODITIES BY WEIGHT.

Resolved, That we, the delegates of the Twelftl Annual Conference on Weights and Measures in convention assembled, indor'se tlie principle of the sale of all dry commodities by weight in so far as this method of sale is practicable, and respectfully urge upon Congress the imperative necessity of enacting legislation designed to put this method of sale into force and effect throughout the United States.

Mr. Tucker. I move the adoption of the resolution.

Mr. Buck. I second the motion.

(The motion was agreed to.) 
Mr. Sмrth (reading):

RESOLUTION IN RE METRIC SYSTEM.

Resolved, That we, the delegates of the Twelfth Annual Conference on Weights and Measures in convention assembled, realizing the inherent simplicity of the metric system of weights and measures and the difficulties and handicaps imposed upon the people and industries of the United States by the continued use of the antiquated and cumbersome system of weights and measures customarily employed, do hereby state our conviction that the general adoption of the metric system in trade, commerce, and industry will be of inestimable benefit to the country, both in its internal and foreign relations.

Mr. GREGG. Does that contemplate the adoption of the metric system?

Mr. Sirth. Yes; I think so.

Mr. GREGG. I do not know that I fully understand that resolution, and I will have to file a minority report as a member of the resolutions committee on that question. That being the purpose, I will ask the secretairy to read the minority report prepared by myself and another member of the resolutions committee who disagree on this particular point only. That is the only point, we disagree upon. I did not have the opportunity, Mr. Chairman, of attending the meeting yesterday morning, having been detained on business matters, but one member of this committee went over the questions in detail with me yesterday, and we came to the conclusion that we could not agree to the majority report on that particular question.

The SECRETARY (reading):

We, the undersigned members of the committee on resolutions, beg leave to submit the following conclusions on the resolutions submitted to this conference by the majority of the committee:

1. We submit that all of the resolutions submitted by the majority meet our approval and indorsement, except the resolution which has for its object the establishment of the metric system of weights and measures to the exclusion of all other systems.

2. We can not agree to this resolution for the reason that we do not believe that the country is ready for this radical and far-reaching change. It will necessitate a complete reorganization of our entire industrial and economic: system in making the change from the dual system now in use throughout the country, the English system predominating in all domestic commercial intercourse and transaction. We submit that the adoption of any other than the Eliglish system of weights and measures for domestic use will have to be brought about by a systematic education, which will require the work of more than one generation. We submit, furthermore, that the adoption of the metric system at this time (to the exclusion of any other system) will bring about sucial unrest and confusion.

Respectfully submitted.

Webster (New Hampshire). Gregg (Texas).

Mr. BARNARD. In the interests of harmony, and inasmuch as it is almost the lunch hour, I move that this particular resolution be laid over until after that hour to give time for its consideration.

(The motion was seconded and agreed to.)

Mr. SMITH (reading):

\section{RESOLUTION IN RE EDUCATION OF PUBLIC.}

Whereas our experience as weights and measures officials reveals a very general and deplorable lack of ability on the part of the purchasing public properly to protect themselves against short weight and measure practices through ignorance of the proper use of weighing and measuring apparatus and 
of laws and regulations prescribing the metbods of sale to be employed. Therefore be it

Resolved, Tbat it is the sense of this Twelfth Annual Conference on Weights and Measures that the education of our future citizens along weights and measures lines should have its inception during the formative period of their lives; namely, in the public schools.

Mr. Barnard. I move the adoption of the resolution.

Mr. TIGHe. You state "public schools." There are parochial schools in every section of the country, and in some cities they have more children than the public schools. Why not include them?

Mr. Holbrook. I move we strike out the word "public."

Mr. TIgHe. I also move that the word ignorance in reference to the public be stricken out, and some other word used, such as unfamiliar.

The Acting Chairman. Will you read it with those changes, Mr. Smith?

Mr. Sмiтh (reading) :

RESOIUTION IN HE EDUCATION OF THE PUBI.IC.

Whereas our experience as weights and measures officials reveals a very general and deplorable lack of ability on the part of the purchasing public properly to protect themselves against short weight and measure practices tbrougb lack of knowledge of the proper use of weighing and measuring apparatus and of laws and regulations prescribing the metlods of sale to be employed. Therefore be it

Resolved, Tbat it is the sense of this Twelfth Annual Conference on Weights and Measures that the education of our future citizens along weights and measures lines should have its inception during the fornlative period of their. lives, namely, in all schools.

The Acting Chamman. That seems to cover it.

(It was regularly moved and seconded that the resolution as anended be adopted, and the motion was agreed to.)

Mr. Sмiтн (reading):

RESOLUTION IN RE STANDARDIZATION OF PACKAGES.

Whereas we, as weights and neasures officials, realize that our present laws requiring the quantity of the contents to be marked upon food in package form fail adequately to safeguard the public in the purcbase of commodities so put up: Therefore be it

Resolved, Tbat this, the Twelfth Annual Conference on Weigbts and Measures, record its conviction that standardization of packages is vitally necessary for the proper and complete protection of the purchasers of commorities so packed.

(It was regularly moved and seconded that the resolution as read be adopted, and the motion was agreed to.)

Mr. Simrr. As a matter of information to the conference I would like to call their attention to the phraseology in the majority report of the committee on the metric-system resolution. The language to which I refer is as follows: "Do hereby state our conviction that the general adoption of the metric system in trade, commerce, and industry will be of inestimable benefit to the country, both in its internal and foreign relations."

You will note that the resolution does not state that the conference goes on record as favoring the immediate adoption of the system to the exclusion of all others. It states that the change will be of benefit.

The Acting Ciratrmax. That will be taken up after dinner. 
Mr. Barnard. If it is the pleasure of the chairman and delegates I will at this time submit the report of the resolutions committee on the death of our brothers who have passed away during the past year.

REPORT OF SPECIAL COMMITTEE ON RESOLUTIONS, PRESENTED BY F. G. BARNARD.

Whereas an All-Wise Providence has seen fit in His judgment to call from our midst John C. Connors, one of our oldest, most loved, and valued members : Therefore be it

Resolved, That in his death the weights and measures officials of the United States have lost one who was always ready and willing to give his time, and from his vast store of practical knowledge the assistance and advice they at any time requested; and, while we bow in humble submission to the will of Him who doeth all things well, we extend to his wife and family our heartfelt sympathy, assuring them that, while he has gone, his memory

- will always be cherished by the weights and measures officials of the United States; and

Be it further resolved, That a copy of these resolutions be spread upon the minutes of this association and a copy of same, properly engrossed, sent to his fumily.

F. G. BARNARD.

F. S. HoLbrook.

WM. F. CluetT.

(It was regularly moved and seconded that the resolution as read be adopted, and the motion was agreed to by a rising vote of the members.)

Whereas the Twelfth Annual Conference of the Weights and Measures Officials of the United States have learned witl deep legret of the death of John $\mathbf{R}$. Willett, chief inspector of weights and measures of Indiana, one of its oldest and most loved member's: Therefor'e be it

Resolved, That, while we bow in humble submission to the will of Him who doeth all things well, we deeply deplore his death and extend to his wife and family our heartfelt sympathy, assuring them that, while he has gone, his memory will always be cherished by the weights and measures officials of the United States; and

Be it further resolved, That a copy of these resolutions be spread upon the miuntes of this conference, and a copy of sume, properly engrossed, sent to his family.

F. G. BARNARD.

F. S. HOLBROOK.

WM. F. Cluett.

(It was regularly moved and seconded that the resolution as read be adopted, and the motion was agreed to by a rising vote of the members.)

Whereas the Twelfth Annual Conference of the Weights and Measures Officials of the Uniter States have learned with deep regret of the death of James R. Smith, city sealer of weights and measures, Nashville, Tenn., one of its respected and loved members: Therefore be it

Resolved, That while we bow in humble submission to the will of Him who doeth all things well, we deeply deplore his death and extend to his wife and fanily our heartfelt sympathy, assuring them that, while he has gone, his memory will always be cherished by the Weights and Measures Officials of the United States; and

Be it further resolved, That a cony of these resolutions be spread upon the minutes of this conference, and a copy of same, properly engrossed, be sent to his family.

F. G. BARNARD.

F. S. Holbrook.

WM. F. CluetT. 
TWELFTH ANNUAL CONFERENCE ON WEIGHTS AND MEASURES. 209

(It was regularly moved and seconded that the resolution as read be adopted, and the motion was agreed to be a rising vote of the members.)

Mr. Barnard. Inasmuch as this convention has stood a minute in silence in memory of one of its members, I think that we should at this time arise in memory of John T. Willett and James $R$. Smith and devote a minute of time to silence.

(The delegates arose and stood for one minute in silence.

A motion to recess for lunch was regularly made and seconded, and the motion was agreed to.

Accordingly, at 1.30 o'clock p. m., the conference took a recess for luncheon.)

$155530-20-14$ 


\section{EIGHTH SESSION (AFTERNOON OF SATURDAY, MAY 24, 1919).}

The conference reassembled at 2.15 o'clock p. m., Dr. S. W. Stratton, chairman, presiding.

REPORT OF COMMITTEE ON RESOLUTIONS-Continued.

Mr. Smrth. The resolutions committee has amplified somewhat the resolution in regard to the metric system. I will read it:

RESOLUTION IN RE METRIC SYSTEM.

Resolved, That we, the delegates of the Twelfth Annual Conference on Weights and Measures in convention assembled, realizing the inherent simplicity of the metric system of weights and measures and the difficulties and handicaps imposed upon the people and industries of the United States by the continued use of the antiquated and cumbersome system of weights and measures customarily employed, do hereby state our conviction that the general adoption of the metric system in trade, commerce, and industry would be of inestimable benefit to the country, both in its internal and foreign relations; and in order to prepare the public for the adoption of this system, and to bring about a more general understanding thereof it is recommended that it be more generally taught in our schools.

Mr. GreGG. I think the amplified resolution covers the objections that might have been urged to the original resolution; therefore, on behalf of the minority, I want to withdraw the minority report.

Mr. Barnard. I move the adoption of the resolution.

Mr. Buck. I second the motion.

The Chairman. I want to say in connection with this that I am very glad, indeed, that this minority report has been withdrawn. I have found from long experience that people are very apt to get two things confused in this discussion of the metric system. There are questions which pertain to it as a system of weights and measures, and those questions we should study, and study carefully and go into them; and then there are questions as to its method of adoption. There is a very great disagreement as to the proper method of adoption that will have to be studied very carefully. It appears to me the resolution before you is all right and as far as we can go at this time, and as time goes on you will be thinking more and more of these two phases of this question and be in a better position to discuss them than we are to-day, so I am really very glad you have put it in this form. It will do a great deal of good, and yet not do any harm.

You have heard the motion and second. Those in favor will say "Aye"; contrary, "No."

(The motion was agreed to).

Mr. Smith (reading):

BESOLUTION OF APPRECIATION TO SECRETARY OF COMMERCE.

Resolved, That we, the delegates of the Twelfth Annual Conference on Weights and Measures, do hereby extend a vote of thanks to the Secretary of 
Commerce, Hon. William C. Redfield, and the secretary of this conference is hereby instructed to prepare in proper form and transmit to the Hon. William C. Redfield a copy of this resolution.

(It was regularly moved and seconded that the resolution as read be adopted, and the motion was agreed to.)

Mr. SMrTH (reading):

RESOLUTION OF APPRECIATION TO VARIOUS MEMBERS OF THE BUREAU OF STANDARDS.

Resolved, That the Twelfth Annual Conference on Weights and Measures do hereby gratefully acknowledge by a vote of thanks their sincere appreciation of the favors made possible by the untiring efforts of Dr. S. W. Stratton, Mr. L. A. Fischer, the members of the Weights and Measures Division, and other members of the Bureau of Standard.

(It was regularly moved and seconded that the resolution as read be adopted, and the motion was agreed to.)

Mr. SMith (reading).

RESOLUTION OF APPRECIATION TO OTHER PERSONS ASSISTING.

Resolved, That the Twelfth Annual Conference on Weights and Measures extend a vote of thanks to Miss Steere, the estimable lady who has so generously prepared luncheons for the members of this conference from day to day during its sessions and to those who have so ably assisted her.

Resolved further, That we extend a vote of thanks and appreciation to $\mathrm{Mr}$. Fred H. Monk, our stenographer, who has so faithfully maintained his post of duty and recorded all the proceedings of this convention during its sessions.

(It was regularly moved and seconded that the resolution as read be adopted, and the motion was agreed to.)

\section{CREATION OF PERMANENT COMMITTEE ON LEGISIATION.}

Mr. GRegG. I do not know whether I am in order, as I am a new nember of this conference and come to sit at the door of the temple before getting admission to the sanctuary; but I want to make a motion if it is in order, Mr. Chairman, that the chair be empowered to appoint at this time a permanent committee. I do not know whether it will be necessary to proceed by formal resolution or whether an extemporaneous motion may be made, but the motion that I want to put-and if it is out of order, so declare it, you will not offend me-is this: That the chair be empowered to appoint a permanent committee of either three or five, who will be known as the permanent committee on legislation to secure uniformity in legislation throughout the country on weights and measures.

Mr. Barnard. I will support that resolution.

Mr. GregG. It may be awkwardly put.

The Chamman. That is very well put and a very important thing, too. Are there any remarks?

I want to say that three or four of the bodies that I am attached to have a committee of that kind. In some cases it is called the committee on governmental relations, and in others legislative. Such a committee, it seems to me, would be of very great advantage. It probably ought to consist of as many as five members. Are there any further remarks on this? If not, those in favor of the motion say "Aye;" contrary "No."

(The motion was agreed to.) 
The Chamman. The chair will appoint this committee later. Are there any other motions?

Mr. BARNARD. The committee appointed two years ago for the purpose of drawing a bill on sales by weight is ready to report whenever you are ready for that report.

The Charrman. The report will be in order.

\section{REPORT OF COMMITTEE ON SALES BY WEIGHT, PRESENTED BY.} F. G. BARNARD.

$\mathrm{Mr}$. Chairman and gentlemen of the conference, for the benefit of those who were not here in 1916 at the last conference, I wish to advise that at several conferences the matter of eliminating as far as possible the dry measure in the sale of commodities at retail has been discussed, and finally, in 1916, a motion was made that the chair appoint a committee of three to draft a bill covering that proposition and present the same to the next conference. The chair appointed Mr. C. C. Neale, of Minnesota; Mr. John M. Mote, of Ohio; and myself as the committee to draw this bill. I might state that during the last two years there has been a great deal of difficulty in getting the committee together, but nevertheless we did not lose sight of the duties that were imposed upon us, and by means of correspondence and otherwise we have prepared a measure, which is signed by two members of the committee. Mr. Neale, being unable to be here, was unable to sign it, of course. The bill is as follows: A BILL To provide for the sale by weight of certain commodities and to provide a penalty
for the violation thereof.

Be it enacted by the Senate and House of Representatives oi the United States o; America in Congress assembled, That all articles hereinafter mentioned, when sold, shall be sold by avoirdupois net weight or numerical count, except when same are sold in containers standardized by act of Congress, to wit: Apples, grapes, peaches, pears, plums, quinces, cranberries, prunes, raisins, lates, figs, dried apples, dried peaches, apricots, rice, beans, green beans, carrots, onions, par'snips, potatoes, sweet potatoes, tomatoes, turnips, beets, peas, green peas, buckwheat, corn in ear, shelled corn, corn meals, flour, wheat, lye, oats, sweet coln in ear, shelled sweet corn, hominy, dried sweet corn, pop corn in ear, shelled pop corn, blue-grass seed, broom-corn seed, canary seed, cotton seed, clover seed, timothy seed, hempseed, malt, millet, onion sets, orchard-grass seed, rapeseed, redtop seed, English walnuts, black walnuts, hickory nuts, Brazil nuts, pecans, almonds, filbelts, ice, coal, coke, lime, salt, sugar, tea, coffee, bulk spices, cheese, butter, oleomargarine, lard, fresh and salt meats, fish, game fowls, chopped feed, candy, and other commodities usually and customarily sold by weight: Provided, That nothing in this section shall apply to seeds in sealed packages: Provided further, That the provisions of this section shall not apply to the sale of any article where both buyer and seller in writing agree to other methods of sale: And Provided further, That nothing in this section shall prohibit the sale of fresh fruits or vegetables which are customarily sold by the bunch, such as young onions, radishes, celery, and water cress.

Sec. 2. That whoever by himself, his servant, or agent, or as the servant or agent of another person, firm, or corporation, sells or offers for sale any articles enumerated in section 1 of this act in any other manner than provided by this act in any State, Territory, or the District of Columbia shall be deemed guilty of a misdemeanor, and upon conviction thereof in the court of the United States having jurisdiction, shall, for the first offense be punished by a fine of not less than $\$ 100$ nol $^{\circ}$ more than $\$ 200$ and cost of prosecution, or by imprisonment not to exceed three months; for the second and subsequent offenses by a fine of $\$ 500$ and cost of prosecution, or by imprisonment not to exceed six months. 
SEc. 3. That rules and regulations for the enforcement of this act not inconsistent with the provisions of this act shall be made by the Director of the United States Bureau of Standards and approved by the Secretary of Commerce. Prosecution for offenses under this act may be begun upon complaint of local sealers of weights and measures or other officers of the several States and Territories appointed to enforce the laws of the States and Territories, respectively. relative to the weights and measures.

We itemized these different commodities under the advice of the attorney general of Michigan, who advised me that it was questionable in his mind if the dry measure could be eliminated, inasmuch as he thought it was authorized by the Constitution. He advised us that in itemizing these commodities we would get around that proposition, and the act would be constitutional.

\section{DISCUSSION.}

The Chamman. You have heard the report of this committee. What is your pleasure in regard to it? Should this be acted upon or referred to this committee on legislation?

Mr. Hasson. I make a motion that this be referred to the committee on legislation.

Mr. Tighe. I second the motion.

The Cifairman. Are there any remarks?

Mr. GREGG. There is one provision only in the proposed legislation which, as I see it, might be objectionable, and that is the penal provision-the penalties imposed. Now, I believe that more effective cooperation in the enforcement of the law can be secured by rendering contracts entered under any other system than that prescribed by this act null and void and nonenforceable. If you put it upon a civil basis, I believe that you will get more hearty cooperation from the public generally than you will if it be made a penal statute. I am one of those old-fashioned fellows that believe we have too many penal statutes now. We have so many penal statutes, Federal and State, that no lawyer in the country can carry an index to the Penal Code, much less know anything about it. I believe if you make the penalties civil rather than criminal you would get a more hearty indorsement of the proposition.

Mr. BARNARD. It seems to me that in doing that we will be apt to take the teeth out of the bill. Possibly our friend from Texas is able to enforce the laws of Texas by the Golden Rule, but we find that in other sections of the country some of the persons that we have to deal with do not seem to comprehend that rule.

Mr. Hanson. Is it not a fundamental principle of law that where any sale is made in contravention of a statute that the vendor can not recover in such a case.

The Chamman. I think so.

Mr. Mоте. A statute similar to this was enacted in Ohio and was declared to be unconstitutional.

The Chairman. Similar to the proposed bill?

Mr. Mote. The view of the Supreme Court there was to the effect that if we require a contract to be made in writing we deprive the individual of the right of verbal contract. However, the decision of the court stood 4 to 3 , which was something near a tie. They did not have anything like a large majority in the decision, but it resolved 
itself down to this, that you place the individual upon his honesty and upon his integrity to obey this statute. In Ohio the people who were desirous of giving honest weight and measure retained the system of sales by weight, while the fellow who sought to defraud immediately grabbed up a set of fake measures and started out with them. So our experience with the bill was that the people who wanted to take advantage of the court's decision and deal out 11 pounds of potatoes for a peck were the first ones to use the measure. while in other sections, the merchants who wanted to buy bought 60 pounds of potatoes to the bushel and gave 15 pounds to the peck. They continue to sell these commodities by weight. It is my opinion that the statute such as that recommended by Mr. Gregg would not reach individuals such as the commission men, who-I will say in the State of Ohio-are not to be trusted or to be dealt with as though it were their own desire to be honest.

A Member. I favor the criminal prosecution as recommended by the committee, with the exception that the penalties are altogether too severe. The minimum penalty of $\$ 100$ is excessive, so excessive that I believe it will be not applied. If that were made not more than $\$ 100$ for the first offense, it would give the judge the opportunity to fix the penalties to fit the individual crime. I think it would be far more effective in actual application.

Mr. Barnard. These figures are put in there as a tentative proposition. Therefore, I do not have any objection to putting in that fine if you want it there.

Mr. GREGG. I do not believe you gentlemen fully understand the object of having the bill changed as suggested. If you make any contract entered into unenforceable where any other system is used save and except that prescribed by law, a man is going to be careful after he once loses his property by overstepping the law, and it will make a much greater impression upon him and really make him a better citizen to punish him in that way than it is to haul him up in the penal courts for some lapse of memory.

The Chatruan. It seems to me the remarks have shown clearly that this matter should be further discussed. The motion before you is to refer it to the committee on legislation with the view that that committee look into this matter and report at the next meeting. Are there any further remarks?

Mr. Mote. It is my opinion that there should be some recommendation to this legislative committee to the effect that some action might be taken in this regard before the next meeting. I am very much in favor of, and I believe that the assemblage here in general wish to see some kind of a law presented at the earliest possible moment providing for sales by weight.

The Crairman. Could we not indorse the principle of sales by weight and then refer to this committee?

Mr. Mote. That is, with a recommendation that some action be taken in the way of having a bill presented to the next meeting.

The Chairman. The motion before us is to refer this to the committee on legislation.

(The motion was agreed to.)

The Chatrman. Now a motion will be in order to commit the conference, if it so desires, to the features of this, 
Mr. Mote. I make a motion that the legislative committee to which this bill is referred be instructed to take some action in the way of preparation of a bill along the lines suggested here to be introduced in the present Congress.

(The motion was seconded and agreed to.)

REMARKS BY DR. S. W. STRATTON, PRESIDENT.

I wish to thank Mr. Fischer and the various people who have helped out for their courtesy. The first day of my absence I attended a new organization known as the Industrial Conference Board. It is a group of representative business men of the country who meet together once a month and discuss matters of great importance to industry. The second day I had the pleasure of reading a paper before the Iron and Steel Institute and to listen to a good many of their discussions, and especially to the speech of Judge Gary.

The Iron and Steel Institute represents probably the greatest industry in this country, and it will give you some idea of the size of that industry when I tell you there were 1,200 or 1,300 at the banquet last night. The substance of Judge Gary's remarks were in part that the industry had learned a good many things recently; that their relations with the Government were not in the past what they should have been; and that they had learned especially a good deal in regard to that.

At the other meeting of the day before they discussed similar things. I might sum it all up in one sentence, that it is the desire of the leaders of business and industry to decide all matters on the basis of what is fair and just to one another, and what is fair and just to the public, and what is fair and just to labor. I thought as they were speaking at both places of this conference going on in Washington, how it represented one of the very large and important items which are going to enter into this new order of things. Your actions here are very much more far-reaching than you imagine. Never before have we had a meeting which has devoted itself so carefully and continuously to technical matters. This has been an education in weights and measures to anyone who has not attended the meetings before, and the character of the meeting will go on improving as more members come and as you gain more and more experience in weights and measures.

I could not help comparing this meeting with the earlier meetings, where only a few had experience in these things and the larger part were inexperienced, but interested. To-day nearly all of our members come with things that they have put into practice, and they want light and discussion on these things. There are a few here for the first time, but even they have come with some suggestions along many lines.

I was pleased this morning that when you were discussing these specifications regarding gasoline pumps the makers were here. Now, we have found in many, many conferences of this kind on various subjects that there are nearly always two and sometimes three parties to the specifications - the user, the manufacturer, and the various officials involved. If the manufacturer is present at a discussion of 
this kind, and has an opportunity to ask why these things are done. and sees there is a good reasoll for it-and they ought not to be done unless there is a good reason-he does not feel that something has been arbitrarily forced upon him. The same is true of the users. You, as sealers, represent the public, and there are many cases where the public should be represented on a thing of this kind, as well as the officials and manufacturers. As long as we proceed along these lines, we are not only going to get rules and regulations which are wise and just, but we are going to have the support of all of the parties concerned.

This action you took this morning and similar actions are of the greatest help to the new members of the conference and to officials all over the country. This movement is just beginning. It is going to grow even beyond what you anticipate, and all of these codes or regulations, whatevel you may call them, will be taken as the standard by the new States and new cities that come into the organization. It is going to be even mole far-reaching than that. During the past winter we have had delegates here at the Bureau from South Africa, Canada, Australia, and Japan, all looking toward the establishment of an institution similar to the Bureau of Standards, and one of the things they have in mind, of course, is weights and measures. Standards of measurement and standards in quality are the two things this institution is looking after. Now, as those institutions are established throughout the world, your resolutions and regulations and all material which you have adopted and put into practice and found workable are going to be taken as the basis of their actions. I received a telegram this morning requesting me to appear before the committee of the Canadian Parliament during the first week of June, in regard to matters such as you have been discussing. I am more than pleased to note the seriousness with which you have taken this work and the way in which you have gotten down to the real technical facts that are so essential to it. I want to thank you for your courtesy in coming and the suggestions that you have given to us. I have always said that, while the original object of the conference was to bring the Bureau to the sealers, I am quite sure we have received more from them, and more from these manufacturers of weights and measures, than we give to them. It is, at any rate, a 50-50 proposition. Again, let me say to you that we hope you will come back next year with many good suggestions in regard to the carrying out of these things. The great thing about all of this is that if we have adopted regulations this year which are found to be wrong or if conditions change in the next year, we can change them. That is the great advantage of an organization of this kind. If we do not progress, we stand still. I thank you.

Mr. Hanson. According to the program, we are scheduled to visit the Division of Weights and Measures Building and be entertained there by exhibitions of the various appliances. Does that still hold good, although it is Saturday afternon?

The Chamman. There will be some one there. We will be very glad to have you visit it.

Mr. Моте. I believe there was something said yesterday in regard to the delegates being supplied with the address made by the Secre- 
tary of Commerce. I wonder if any steps have been taken to supply the delegates with that instead of waiting until we get it in the full report.

The Secretary. I may state that this address has been prepared and sent down to the Secretary. Instructions were given that as soon as it came back copies should be gotten out. Whether it has been done or not I can not say. We certainly will get them in a day or two. I will be glad to see that ererybody is supplied who stays and goes through the Bureau. We hare also given instructions to have a list of the officers struck off, and that will be ready in a few minutes. I think the best way to distribute these would be as you go out.

Mr. Bove. I wish to suggest that it would be a good idea for the conference to extend a special invitation to the governor of each State and the mayor of each city to be present here at our next conference. I would like to know if that is a good idea.

The Chairmas. Would not you modify that to the extent of asking them to be present and if they can not come to send a delegate?

Mr. Bore. That would be a good idea.

Dr. Reichmaxx. I move that the suggestion be referred to the executive committee.

(The motion was seconded and agreed to.)

Mr. Fine. In reference to the address of Secretary Redfield, I was told this morning it had to be submitted to him first, and, as he was busy and had to go away, it was delayed.

The Chairman. I think that unless the report is to be gotten out sooner than we hare before, it would be a rery good idea to send out a résumé of the proceedings here, what has taken place, in order that you might use it until you get the report. Perhaps we may persuade the Secretary and numerous others who have assisted here to get it out.

Mr. Stewart. I notice in giving the name of each delegate attending the convention they also give us the State, but they do not give us the address in case we want to write.

Mr. Haxson. It is implied that erery man has his headquarters in the capital of the State.

Mr. Stewart. Many of the men on this list are county men and we do not know whether they live in Jacksonville or Thomasrille. or Davisville, but they lire somewhere in that county.

The Chatriman. It might be a good idea to have a directory of the weights and measures officials duplicated and sent out.

The Secretary. We have a complete list of weights and measures officials, but there are so many changes that it is impracticable to print it. We hare it in card form and whenerer anyone asks for a list we find it advantageous to make them a list up to date. If we give them a list six months old, there would be a good many changes in it. Until these positions become more permanent. it is going to be a difficult matter to do what you ask. We would like to do it.

Mr. Haxsox. Some years ago. I believe, the Bureau compiled all the laws in the various States relative to weights and measures. Do you expect soon to compile another edition of such laws?

The Secretary. There has been a great deal of work done on that and we expect to get it out as early as practicable. 


\section{DISCUSSION OF QUESTIONS INVOLVING LEGAL PROCEDURE.}

Mr. Hanson. Another thing I would like to bring to the attention of the Bureau is this. In my State I have collected all the supreme court cases and have made an abstract of them. I think it would be a good idea if we could get all the supreme court cases in other States, or in some of the leading States, and have them abstracted for future reference. In our State some of our supreme court cases go back to 1780 , and fundamental rules of law have been established and still hold good.

Mr. Barnard. There is one other matter I had in mind. A number of us had a little conference of our own last night in discussing Dr. Alsberg's remarks of yesterday. He stated in the course of his remarks that his bureau did not feel disposed to define a package and to establish a rule that wrapped hams and bacons should bear on the principal label thereof the net weight of the article. In view of this we decided that as soon as the occasion presented itself we would start a number of cases against dealers who are selling hams and bacons in wrapped packages and rush these cases through to the Supreme Court as rapidly as possible in order to get a decision from that court. Dr. Alsberg holds that in his opinion that is the proper way to settle the matter. I wondered if you approve action of that kind.

The Charrman. Sometimes that is the only way to get things started. These prosecutions would be made under your State law, would they not? Are there any opinions in regard to that?

Mr. Hanson. A supreme court decision gained in one of your States would not necessarily have anything to do with interstate commerce at all. It may be a separate point of law. If Massachusetts should decide that certain hams should be considered in package form, that absolutely would have nothing to do with the interstate proposition at all; as long as this particular kind of bacon is in the original package the laws in the State do not apply. The interpretation as to whether hams and bacon are in package form or not naturally should be taken up through the Federal District Courts.

Mr. BARNARD. The Chicago packers are shipping considerable hams and bacons in wrapped form into the territory which I represent, and I have previously taken the matter up with the Federal authorities, and they inform me that if I see fit to start a case of that kind they will, if the evidence is sufficient to warrant the action, be willing to go ahead with it. I think it would be an easy matter to start an interstate case in that respect, if deemed advisable.

Mr. GregG. Mr. Hanson raised a point that I was going to suggest. These cases can only come to the Supreme Court of the United States, or to the appellate jurisdiction thereof, through the regular channel of the Federal courts. If there is a doubt about its being a violation of a Federal law, of course the only way to decide that question is to get it into the district court. The decision of the State court, of course, will not be binding except in that particular jurisdiction.

Mr. More. Mr. Chairman, it seems to me as though it might be well in view of the resolution adopted here yesterday, pertaining to a decision of the Department of Agriculture to the effect that hams and bacons were not in package form when wrapped-it might be 
well if we would await.the action of the Department of Agriculture in regard to that decision before any action of this kind, because if a case was started it would undoubtedly result in the packers referring to that decision of the Department of Agriculture as their first defense, and we would have extreme difficulty. We got a law enacted in the State of Ohio that absolutely forbids the commodities to be sold with the weight of the paper included as a part of the commodity sold. The packers were putting up 47 pounds of lard and billing it as 50 pounds, at 32 cents a pound, and getting 96 cents for a can ordinarily worth one-fourth of that. I have seen as much as $\$ 2.08$ worth of paper wrapped around a box of pork loins, whele paper was not necessary. There should be some action taken, and I believe it would be the best way if the Department of Agriculture would make a different ruling.

The Chamman. What is the weight of the package, and of the paper?

Mr. Motre. I have taken as nutch as 14 ounces of paper from a piece of ham.

Mr. Hanson. 'The short weight has nothing to do with whether or not ham or bacon as wrapped is in the meaning of the law in package form. We have no difficulty in conricting if they sell hams and charge for the paper, but the point of the resolution is that we want the amount of meat marked on the outside of the package in a conspicuous and plain manner. It is a question of the package being marked, not of short weight. I believe that the Attorney General of the United States has sent a communication to the department saying that where the department has made a ruling such as they hare, hams and bacons were not in the meaning of the law in package form, he would simply say "The ruling is O. K." But if the Bureau of Chemistry will not reverse their decision as to hams and bacon, the only way you can do is to take an interstate shipment and commence to prosecute in the district court. The question would be, Is ham and bacon, as wrapped, food in package form?

Mr. BARNARD. That was my contention.

Mr. Straples. I had a case of that kind in the Supreme Court of Minnesota, and the court ruled that the ham or the piece of bacon was an original package and it could be sold as such, including the wrapping, and I lost the case.

$\mathrm{Mr}$. HoLвRоок. Was it an interstate shipment?

Mr. Staples. No; it was not an interstate shipment.

Mr. Hanson. Is the Supreme Court of that State the court of last resort?

Mr. Staples. It is the court of last resort.

Mr. Holbrook. Were you prosecuting under the State law?

Mr. Staples. Yes; I prosecuted under the State law.

Mr. Hanson. Could you give me the citation of that, please? I would like to look up the decision.

Mr. Staples. I have not got it here. I can give it to you.

Mr. Hanson. The issue involved there may be a different issue.

Mr. Staples. These goods were packed in Minnesota.

Mr. Houbrook. A great many of these decisions vary when brought under various State laws, because the State laws attempt to define a package, and therefore what is a package in one State is not neces- 
sarily a package in another State. If the law of the State defines a package, the definition is good in that State in regard to the matter, but the case will not be a precedent in any State having a definition which varies in any essential respect.

The Crratrman. This is not in the form of a motion. I do not understand that there is any motion before the house.

Mr. BARnard. I simply asked your opinion whether you thought it advisable to take action to have the courts define a package and state whether in their judgment it should be marked with the net weight.

Mr. Hanson. It is understood, of course, that the average local sealer has no jurisdiction over interstate shipments. If ham or bacon is shipped in interstate commerce. he would have to make information to the United States District Attorney relative to this, and it is up to the latter to take action if he cares to.

Mr. Barnard. I understood that.

Mr. Tucker. When are goods shipped from one State to another out of interstate control?

Mr. Ноцввоок. It would take a good many pages to describe that in detail, but I think I am correct when I say briefly that in general it has been held by the courts that they go out of interstate control when they have been mixed with the general property of the State, and that they have been mixed with the general property of the State after the first sale within the State. I would not say that definitely, but I think that is the case.

Mr. Hanson. That is right.

Mr. Ноцввоок. For instance, if the package is shipped from outside the State to John Jones in Minnesota, he is protected in the sale of that package, but if he sells it to William Smith and it passes by sale from William Smith to any other person in the State, the State regulations take effect.

The theory of the courts in that case is that in order fully to protect a man who is buying goods in interstate commerce, they must so protect him that he can dispose of the goods, as otherwise the purchase of them for sale would be of no benefit to him. Therefore, when John Jones in the State of Minnesota, for instance, gets that package, the courts hold that in order to protect him, he must be able to dispose of that package; but they do not protect a man who has bought within the State and attempts to sell again within the State.

Mr. Austrs. Just a question in connection with this. A packer of Illinois has a branch in the city of Detroit. They consign a quantity of hams or other commodities to their branch office for distribution. The sale is made by the branch office in Detroit to some other business institution within the State. Is that commodity then out of interstate commerce when it is sold by the branch office in Detroit, within the State?

Mr. Houвrook. I think not.

Mr. Staples. Not until the second sale?

The Criarman. The branch office would be just receiver.

Mr. Stewart. Have we not a decision of the Supreme Court something like this: If goods be shipped into a branch house, and the person there representing that branch house goes out and takes 
orders, and the goods are delivered from that branch house, that that is a sale within a State and has nothing to do with interstate commerce? I think we have a decision, or two or three different decisions. We got one of that kind on liquor.

Mr. HolbrooK. Mr. Chairman, when a decision is in relation to liquor, it usually will not hold in relation to any other commodity, because ever since the time of the Wilson bill Congress has been making special laws upon the liquor question largely to protect the States in the enforcement of their liquor-prohibition laws, and special laws of that sort, when constitutional, take precedence over the general theory.

Mr. BarNard. My intention in trying out this particular matter was to take a sale made from the packers direct to the United States Army into the cantonment at Camp Custer, and I have made every effort to bring forward a very good case. I know that hams and bacons in regular packages are being sold to the Quartermaster's Department. I am under the impression that that would be interstate commerce, would it not, coming from Chicago to the quartermaster's department at Camp Custer?

Mr. HоLвRоoк. That would be interstate commerce, undoubtedly. Mr. Barnard. That is where we intended to make a test case.

Mr. Hanson. As a matter of information, now that the railroads are under the United States Administration and the American Railway Express also, what jurisdiction, if any, have the local sealers of weights and measures over the scales that are used by the railroad companies and express companies within their respective jurisdictions. We know, of course, that in the case of post-office scales we absolutely have no jurisdiction whatsoever. The question was put up to me for an opinion a week or so ago, like this: "Has the local sealer any jurisdiction over any scale which is used for the purpose of determining freight or baggage charges, or otherwise, by any railroad company which is under the jurisdiction of the administration here in Washington?"

Dr. ReIchmanN. You say the local sealer has no jurisdiction in a post office. The sealer of weights and measures in New York had a letter from the Postmaster General requesting that the sealers test the scales and condemn them if found faulty.

Mr. Hanson. I might say to Dr. Reichmann that I wrote to the Third or Fourth Assistant Postmaster General asking for jurisdiction or permission, and he wrote back to me that that was all handled by the United States inspectors and that the State has no jurisdiction whatsoever, but if we wished to go in and cooperate he would be glad to have us do so. We have no jurisdiction.

The Charruran. The railroad law is a very special law and provides for this probably in some blanket way, and the disposition is to take things exactly as they were before, unless there is some particular reason.

Mr. Hanson. One of our local sealers came to test the scales and the scale inspector said the sealer had nothing to do with it.

Mr. StewarT. Is not this the fact, that the railroads are only under Government control; that the properties still belong to the companies; and that therefore any sealer has the same jurisdiction as he had before they were under Government control? 
The Chairman. That is the way it ought to be.

Mr. Stewart. That is the way it is in West Virginia.

The Chamman. We are called upon, are we not, Mr. Holbrook, to test scales. Are we called upon by the Railroad Administration, to test the track scales or by the company owning the scales?

Mr. HoLBRoor. We have calls from both.

The Chatrman. I think you will find that the Railroad Administration would rule that these matters are precisely the same as they were before.

Mr. Hanson. What are you going to do, Doctor, if one of the large companies, through its scale inspector, says he will not recognize the sealer? They have no jurisdiction.

The Chamman. That would have to be taken up with the Railroad Administration and they probably would support your sealer.

Mr. HANSON. I maintain this, that the United States Administration here has simply been acting as trustee for the railroads, and the general principle is, of course, that the trustee has legal title, simply the use of it.

Mr. BARNARd. I might state I experienced a similar proposition with the manager of the American Railroad Express Co. in Battle Creek, and he was going to refuse to allow me to touch the scales that I had a complaint against. I immediately took things in my own hands and went in and tied up the scale with a wire and told him the scale would stay tied up, and if he attempted to untie it I would have a warrant out for him for interferring with me in the discharge of my official duties. He soon came to his senses.

Mr. Hanson. That was no criterion.

The Chairman. We could take that up with the administration. The whole thing is temporary and it will not be very long, I should say, before we get back to the old conditions.

Mr. Hanson. I hope we get back soon.

The Chatrman. Is there any further business? If not, a motion to adjourn is in order.

\section{REPORT OF COMMITTEE ON PUBLICITY, PRESENTED BY L. S. SCHOENTHAL.}

The committee on publicity has performed its duties. We have given a great deal of time to them and have tried to get a great deal of publicity, but we were not very successful, due to the fact that the papers are crowded at the present time with congressional news. However, we did get some items in the paper, and we hope to have quite an article in the Sunday morning papers. I want to say that it has been a pleasure to work with my associates on this committee, and that it is the first committee of any organization I ever worked with wherein the members did their share of the work and the chairman did not have to do it all.

Mr. Tetradlt. I move you, Mr. Chairman, that we adjourn.

The Chairman. You have heard this statement. No action, I take it, is necessary? You have heard the motion to adjourn. Is there a second?

(The motion was seconded and agreed to.

Thereupon, at 3.30 o'clock p. m., Saturday, May 24, the Twelfth Annual Conference on Weights and Measures of the United. States adjourned.) 


\section{APPENDIX.}

\section{SPECIFICATIONS AND TOLERANCES FOR IIQUID-MEASURING PUMPS TENTATIVELY ADOPTED BY THE TWELFTH ANNUAL CONFERENCE ON WEIGHTS AND MIEASURES.}

[For discussion of these specifications and tolernaces, see page 169 et seq. of this report.]

1. Definition.-A liquid-measuring pump is a pump, or a combination of a pump with other mechanism, adapted to the measurement of liquid in definite quantities by volume.

2. Permanence.-(a) Liquid-measuring pumps shall be of such design, construction, and materials that they may reasonably be expected to withstand ordinary usage without impairment of the accuracy of their measurement or the correct functioning of their operating or indicating parts.

(b) The longitudinal axis of the measuring cylinder or chamber shall be accurately plumb when the pump is in level, and a two-way or a circular level, or leveling lugs, or a plumb bob, shall be provided by means of which the level can be established. The installation shall be of such strength and rigidity as to maintain this plumb and level condition.

3. Indicating and registering parts.- $(a)$ Counters, meters, and graduated scales used on liquid-measuring pumps to tally sales and deliveries to individual purchasers shall be so located and disposed that their readings will be visible to the customer, as well as to the operator of the pump.

(b) In the case of measuring pumps used for dispensing gasoline the counters or graduated scales shall be of such size and style that they are clearly visible to, and readable by, the customer from any position which he may reasonably be expected to assume.

4. Units of delivery.-Liquid-measuring pumps shall have the following dissharge capacity per stroke or cycle, and these only: One gallon, a multiple of the gallon, or a binary submultiple of the gallon; that is, a quartity obtained by dividing the gallon by the number 2 or a power of the number 2: Provided, however, That a pump may be constructed to deliver other amounts than the above, corresponding to predetermined prices at a definite price per gallon, but in such cases the pump shall be so constructed that the price per gallon at which it is set at any time and also the amount actually delivered must be clearly indicated.

5. Closure of one outlet.-When two discharge outlets for the liquid are provided on a liquid-measuring pump, the pump shall be so designed and constructed that one outlet must automatically be tightly and completely closed off whenever the other is open, so that no liquid can be discharged except through that outlet which is in use at the time and for the purpose intended.

6. Drainage of discharge piping.-(a) All liquid-measuling pumps used for the sale of gasoline shall be so constructed as to provide for the complete and rapid drainage, to a definite and uniform level, of the liquid contained in the hose or outlet pipe. This specification will be construed to require that hose, If used, shall be properly reinforced and shall be of such length and stiffness and its inlet end at such height above the normal level of its discharge end, when used for the purpose of delivery to an automobile fuel tank, that no movable portion of the hose will be disposed in such a way as to tend to retain liquid after the operation of the pump is completed.

(b) All liquid-measuring pumps shall be so designed and constructed that they will not permit a siphoning or a continuous trickle of liquid from the discharge outlet after the operation of the mechanism is discontinued. All liquid-measuring pumps, which under the foregoing specification are required to be equipped with a standpipe, shall be furnished with a vacuum breaker or 
equivalent device adapted to cause the definite, immediate, and rapid drainage of the downcoming portions of the hose or pipe.

Note.-A standpipe shall be defined as any elevated pipe designed to connect with the upper end of a hose or other novable delirely tube and intended to insure rapid and complete drainage of such delivery tube into the tank or vessel into which liquid is being discharged.

7. Sensitiveness.-All liquid-measuring pumps, of whatever type, used in retail tracle shall be so designed, constructerl, and gralduated that their indications can be read or their discharge readily deternined within an amount which is not greater than the value of the tolerance, as hereinafter provided.

8. Completeness of delivery before indication.-(a) On all defined-stroke, piston-type, liquid-measuring pumps, the construction shall be such that a counter or indicator will indicate clearly and definitely such discharge, and only such discharge, as has actually been completed by the pump proper; that is, the indication of each unit of discharge shall take place only when such full discharge from the measuring cylinder has, in fact, occurred.

(b) Any such counter or trllying device as is requirerl under the foregoing specification shill be so constructed that its dial or pointer is returnable readily to a definite and clear zero reading before the next rlelivery is begun.

9. Pointer's and indicators.-All pointer's and indicators used on counters or computing attachments or otler registering parts sliall be sil shaped that a correct and accurate reading is given. Pointers are required to be symmetrical about the graduation lines at which they may stand, and blunt-ended types of pointers shall not be used.

10. Lettering, graduations.- $(a)$ All markings, instructions, and graduations required under these specifications shall be of such size, design, and location that they will not tend to become obliterated by dirt or oil, or for any other reasons tend easily to become illegible.

(b) The graduations shall be of such character and arrangement that the major ones are clearly distinguishable from the minor ones.

11. Scales in opposite directions prohibited.-The use on a liquid-measuring pump of two graduated scales reading in opposite directions and referable to the same pointer or liquid surface shall not be permitted.

12. Computing charts.-The value graduations on all computing charts used on liquid-measuring pumps shall not exceed 1 cent at all prices per gallon up to and including 30 cents. At any higher price per gallon the value graduation shall not exceed 2 cents: Provided, however, That nothing in the above shall be construed to prevent the placing of a special value graduation to represent each 5-cent interval. These special graduations may take the form of dots, staggered graduations, or similar forms. They shall be so placed that their meaning and value may be clearly understood, but they shall not be placed in the space between the regular graduations.

13. Exhaustion of liquid supply.- -All measuring pumps of which the accuracy of delivery is affected by the lowering of the liquid in the supply tank to a point at or near the intake end of the suction pipe shall be provided with a device which will make the pump inoperable during the continuance of this condition, or shall be so constructed as to warn the purchaser and the operator in a conspicuous and distinct manner that the level of the liquid supply is so low as to endanger the accuracy of the measurement.

14. Use limited to certain liquids.--Liquid-measuring pumps which will not give correct results except when used with liquids having particular propertiesas, for example, high viscosity-shall be conspicuously, clearly, and permanently marked to indicate this limitation. Such wording may take the form, "Not suitable for gasoline or light oils," "Use only for molasses and heavy oils," or "For viscous liquids only."

15. Provision for sealing.-All devices adapted to be altered for adjusting or correcting the delivery of a liquid-measuring pump shall be of such construction that they can be sealed either separately or together in such a manner that the position of none of them can be changed without destroying the seal or seals: Provided, however, That this shall not apply to such devices as alter the price and consequently the delivery of such a pump as is described in the process of specification No. 4 .

1 The conference was of the opinion that this specification should not be at once put into force and effect, but that further data should be obtained in reference to it. See p. 192 of this report. 
16. Stops to be positive.-When the stops or other stroke-limiting devices on a liquid-measuring pump are subject to direct pressure or impact in the operation of the pump, such stops shall be of such construction that the permanence and security of their positions is not solely dependent upon friction; that is, under the conditions designated the construction must provide for a positive, nonfrictional engagement of the parts whose relative motions are to be prevented.

17. Graduated parts secured.-When a liquid-measuring pump is provided with a scale of graduations to indicate or adjust the amount to be delivered, this scale shall be riveted to its support or otherwise permanently fixed in position: Provided, however, That in the case of measuring pumps of the gauge-glass type a sliding scale will be permitted when the displacement of such scale is, by suitable mechanism, automatically prevented at all times when liquid is being discharged from the delivery outlet.

18. Diversion of measured quantity.-There shall be no direct or continuous connection of device adapted to return any portion of the measured liquid from the discharge pipe or outlet of any liquid-measuring pump to the supply tank or pipe of the same. All valves in the suction line which are intended to prevent the reversal of flow of the liquid must be of such design that their closure is automatically effected in the use of the pump.

19. Only one shut-off cock permitted in discharge line.-No more than one shut-off valve or cock intended to be operated by hand for the purpose of cutting off the flow of liquid shall be permitted in the discharge line of a liquidmeasuring pump, and in the case of liquid-measuring pumps with which hose or other movable delivery tube is used, or which require the use of a vacuumbreaking valve or equiralent device, any shut-off valve shall be located as near as possible to the pump itself, and not in the hose line or at the extremity of the hose.

20. Protection against corrosion.-In the case of liquid-measuring pumps which depend for the accuracy of their measurement upon the tightness or perfection of seating of a valve or valves, the material used for tanks, piping, and all such auxiliary apparatus as may contain liquid, including the pump itself, shall be of such nature and properties as to be free from the likelihood of corrosion or rusting or the liberation of particles which will be likely to impair the tightness or correctness of seating of such valves.

21. Limiting height of suction lift.-No defined-stroke, piston-type, liquidmeasuring pump shall be so installed as to work under a total suction head sufficient to cause vaporization of the liquid for which it is used under the highest temperature and lowest barometric pressure likely to occur.

22. Use of adjustments.- $(a)$ No adjustment of the delivery of a defined. stroke, liquid-measuring pump shall be permitted except that intended to produce a piston displacement per cycle of 231 cubic inches per indicated gallon of delivery.

(b) Adjustments of piston displacement to correct for leaks, slippage, excessive length of pipe line, or other defects of the installation shall not be permitted.

23. Stop mechanism to be definitely positioned.-All stops which define the delivery of a liquid-measuring pump shall be clearly and conspicuously marked to indicate the value of discharge volume to which they correspond, and any device intended to vary the discharge by bringing different stops into operation shall be so designed and constructed that it is brought to a definite and accurately defined position and that inadvertent displacement from that position will be obstructed.

24. Position of operating handle.- $(a)$ In all defined-stroke, piston-type, liquid-measuling pumps the initial or starting position of the operating crank or handle shall be defined by a latch or snap which will operate to hold the handle accurately in tliat position when the apparatus is not in use.

(b) The initial position of the handle on all types of defined-stroke, pistontype, liquid-measuring pumps shall be vertically downward. Fandles, which in their starting position are inclined to the vertical or stand vertically upward shall not be permitted.

25. Tolerance.-The tolerance to be allowed in excess or deficiency on all liquid-measuring pumps shall not be greater than 1.8 cubic inches per indicated gallon: Provided, however, That the manufacturers' tolerances or the tolerances on all new liquid-measuring pumps shall not be greater than one-half of the values given above: And provided further, That these latter tolerances 
shall also be applied to all pumps which are being retested after being found incorrect and subsequently adjusted or repaired.

$26{ }^{1}$ Constancy of dclivery.-The amounts delivered shall not vary by more than the tolerances provided above, irrespective of the speed at which the apparatus is operated and irrespcctive of the time elapsing between operations: Provid?d, That for the purpose of test, the condition of the apparatus shall be such that a minimum period of nonuse of 24 hours shall not result in an error of the first delivery of the pump after such period of nonuse greater than the tolerance allowable.

Note.-In applying the above specifications errors due solely to a change in the volume of the containerl liquid, resulting from temperature variations alone, are to be eliminated, since an error of this character is unavoidable in the case of volumetric measurements of this kind when the apparatus is standing unused. This change in volume due to temperature variations is, however; small in amount for all ordinary variations of temperature, amounting to about 0.7 per cent for each $10^{\circ} \mathrm{F}$. change of temperature (or about 1.3 per cent for each $10^{\circ} \mathrm{C}$. change of temperature).

27. In all gauge-glass or float-gauge types of liquid-measuring pumps which have a graduated scale as the sole means of determining the amount of liquid discharged the length on the scale equivalent to the tolerance at any point must be readily appreciable when the character of the indicator and normal distance from the observer's eye is taken into consideration, and in no case shall this length be less than 0.04 inch.

28. Fraudulent construction prohibitcd.-All liquid-measuring pumps shall be of such construction that they are not designed to and may not be used to facilitate the perpetration of fraud.

29. Metric systcm.-No specifications contained in the preceding pages shall be understood or construed to prolibit the sale or use of liquid-measuring devices constructed or graduated in units of the metric system.

The tolerances to be allowed on any liquid-measuring device constructed or graduated in units of the metric system shall be the same as those specified on similar apparatus of an equivalent size or at an equivalent capacity in the customary system.

1 The conference was of the opinion that the italicised portion of this speciflcation should not be at once put into force and effect, but that further data should be obtained in reference to it. See p. 192 of this report. 
